Ana Claudia Mancusi Valeije

\title{
Utilização de informações termodinâmicas e estruturâis na predição de sítios de ligação de receptores nucleares ao DNA: uma abordagem computacional
}


Ana Claudia Mancusi Valeije

\section{Utilização de informações termodinâmicas e estruturais na predição de sítios de ligação de receptores nucleares ao DNA: uma abordagem computacional}

Dissertação de Mestrado apresentada ao Programa de Pós-Graduação Interunidades de Bioinformática da Universidade de São Paulo, como requisito parcial para obtenção do Título de Mestre em Bioinformática.

Orientador: Dr. Paulo Sergio Lopes de Oliveira 
Dedico este trabalho aos amores e pilares da minha vida: à minha mãe, sempre me apoiando em minhas empreitadas malucas e me guiando com sabedoria; ao meu pai por sempre acreditar na minha capacidade e ser um exemplo de honestidade e bondade, sempre; à minha irmã por ser minha grande amiga, pelos momentos de grandes risadas e também pelos de briga, sem os quais minha vida seria muito sem graça; e finalmente ao meu namorado, sempre me ajudando a enfrentar momentos de dificuldade e obstáculos, os quais sem sua ajuda jamais teria conseguido superar. 
Agradeço ao meu orientador pelo auxílio, pelos conselhos e pela paciência durante o desenvolvimento deste trabalho; aos colegas do LBI, pelo apoio e pelos momentos de descontração; aos meus amigos por me proporcionarem momentos únicos de alegria; ao meu namorado, Felipe, cujo apoio, carinho e compreensão foram fundamentais para me manter firme e forte frente a todas as dificuldades; à minha família, Edna, Claudio e Cinthia, por todo o amor, apoio e carinho durante essa jornada e todas as outras que vieram e que ainda estão por vir. 


\section{Resumo}

Os projetos genoma têm fornecido uma grande quantidade de informação sobre a arquitetura gênica e sobre a configuração física de suas respectivas regiões flanqueadoras (RF). Estas RF contêm informações com o potencial de auxiliar na elucidação de vários processos biológicos, como os mecanismos de expressão gênica e de sua regulação. Estes mecanismos são de extrema importância para a compreensão do correto funcionamento dos organismos e das patologias que os afetam. Uma parte significativa dos mecanismos de controle de expressão gênica atuam na fase transcricional. Na base destes mecanismos está o recrutamento de proteínas que se ligam às regiões promotoras da transcrição, as quais são segmentos específicos de DNA que podem estar localizados tanto próximos à região de início da transcrição (TSS) quanto a centenas ou até a milhares de pares de bases dela. Essas proteínas compõem a maquinaria transcricional e podem ativar ou inibir o processo de transcrição. Experimentalmente, os segmentos regulatórios podem ser identificadas utilizando métodos complexos de biologia molecular, tais como SELEX, ChiP-ChiP, ChIP-Seq, dentre outros. Uma estratégia alternativa aos métodos experimentais é a utilização de metodologias computacionais. Análises computacionais tendem a ser mais rápidas, baratas e flexíveis do que protocolos experimentais, além de poderem ser utilizadas em larga escala. Atualmente, os métodos computacionais disponíveis necessitam de informações experimentais para a definição de padrões globais de preferências de sequências de DNA para a ligação de fatores de transcrição (TFBS, em inglês transcription factor binding sites). Entretanto, esses métodos apresentam uma elevada taxa de falso positivos e, por vezes, apresentam também taxas significativas de falso negativos, além de serem limitados ao estudo de fatores de transcrição de espécies bem conhecidas, o que diminui a área de aplicação dos mesmos. Diante deste cenário, o uso de métodos computacionais que não necessitem da informação referente aos sítios de ligação, bem como os que utilizem parâmetros mais robustos de deteç̧ão dos resultados, em detrimento dos escores de pontuação provindos de alinhamentos, podem acrescentar uma sensível melhoria aos processos de predição de regiões regulatórias. Neste projeto, foi desenvolvido um novo modelo computacional (TFBSAnalyzer) para análise e identificação de TFBS em elementos regulatórios, que utiliza técnicas de modelagem molecular para a construção de complexos entre um fator de transcrição ancorado a estruturas de DNA com sequências variáveis de bases e, através de cálculos termodinâmicos de entalpia de ligação, determina uma função de pontuação baseada na energia de ligação e realiza a predição de sítios de ligação ao DNA para o fator de transcrição em análise. Esta abordagem foi testada com três fatores de transcrição como sistemas-modelo, pertencentes à família dos receptores nucleares, a saber: o receptor de estrógeno ER- $\alpha$ (Estrogen Receptor $\alpha$ ), o receptor de ácido retinoico RAR- $\beta$ (Retinoid Acid Receptor $\beta$ ) e o receptor X retinóico RXR (Retinoid X Receptor). Os modelos previstos computacionalmente foram comparados aos dados experimentais disponíveis para estes receptores nucleares, os quais apresentaram as seguintes taxas de FP/FN: 10\%/0 para RAR- $\beta$ e RXR, 21\%/6\% para ER- $\alpha$. Também simulamos um experimento de ChIP-seq do ER- $\alpha$ no genoma humano, cujos genes selecionados foram submetidos a uma análise de enriquecimento de fatores de transcrição curados experimentalmente, que fazem sua regulação, revelando que o receptor de estrógeno está realmente envolvido no processo. Para mostrar a aplicabilidade geral de nosso método, nós modelamos a distribuição de energia de ligação para o receptor NHR-28 isoforma a de Caenorhabditis elegans com DNA . Obtivemos distribuições de energia semelhantes àquelas encontradas para os NRs modelos, portanto seria possível aplicar o método para buscar possíveis TFBSs para este receptor no genoma de C. elegans. Os dados gerados e as metodologias desenvolvidas neste projeto devem acrescentar uma sensível melhoria aos processos de predição de regiões regulatórias e consequentemente auxiliar no entendimento dos mecanismos envolvidos no processo de expressão gênica e de sua regulação. 


\begin{abstract}
The genome projects have provided a lot of information about the genetic architecture, as well as on the physical configuration of their flanking regions (FR). These FR have the potential to aid in the elucidation of many biological processes, such as the mechanisms involved in gene expression and its regulation. These mechanisms are extremely important for undeerstanfind the correct functioning of organisms as well as the pathologies that affect them. A significant part of the control mechanisms of gene expression act during transcription. On the basis of this mechanisms is the recruitment of proteins that bind to promoter regions of transcription, which are specific segments of DNA that can be located either near the transcription start site or at hundreds or even thousands of base pairs away. These proteins form the transcription machinery, which can activate or inhibit the transcription process. The regulatory segments can be identified experimentally using complex methods of molecular biology, such as SELEX, ChIP-chip, ChIP-seq, among others. An alternative strategy to these experimental methods is the use of computational methodologies for predicting regulatory regions. Computational analysis tend to be faster, cheaper and more flexible than the experimental protocols, and can be used on a larger scale. Currently, the available computational methods require information previously obtained from experiments in order to define global standards of preference of DNA-Binding sequences for transcription factors (TFBS - Transcription Factor Binding Sites). However, these methods have a high rate of false positives and sometimes also have significant rates of false negatives, besides being limited to the study of transcription factors of well-known species, which decreases their application area. In this scenario, the use of computational methods that do not require previous information concerning the binding sites and use more robust parameters of results detection, instead of alignment scores, may add significant improvement to the processes of predicting regulatory regions. In this project, we developed a new computational model TFBSAnalyzer) for analysis and identification of regulatory elements using molecular modeling techniques for the construction of complexes between a transcription factor bound to specific DNA structures with variable sequences of bases and, by means of thermodynamic calculations of bond enthalpy, provides a scoring function based on the binding energy and predicts the DNA binding sites for the transcription factor in analysis. This approach was tested initially with three transcription factors as models, belonging to the nuclear receptor family, namely estrogen receptor ER- $\alpha$ (Estrogen Receptor $\alpha$ ), the retinoic acid receptor RAR- $\beta$ (Retinoid Acid Receptor $\beta$ ) and the retinoic X receptor RXR (Retinoid $\mathrm{X}$ Receptor). The computationally predicted models were compared to experimental data available for these nuclear receptors, and presented the following rates of FP/FN: $10 \% / 0$ for RAR- $\beta$ and RXR, $21 \% / 6 \%$ for ER- $\alpha$. We also simulated an experiment of ChIP-seq with ER- $\alpha$ with the human genome, where the selected genes were subjected to a transcription factor enrichment analysis, with curated information, revealing that the estrogen receptor is indeed involved in their regulation. To show that our method has a general applicability, we modeled the binding energy distribution for the NHR-28 receptor, isoform a, from Caenorhabditis elegans. The energy distributions obtained were similar to the ones obtained for the model NR, so it would be possible to use the method and search for possible TFBS in the C. elegans genome. The data generated and the methodologies developed in this project should add a significant improvement to the prediction processes of regulatory regions and, consequently, help to understand the mechanisms involved in the gene expression process and its regulation.
\end{abstract}




\section{Lista de Figuras}

1.1 Estrutura de um motivo dedo de zinco . . . . . . . . . . . . . 2

1.2 Estrutura de um motivo dedo de zinco . . . . . . . . . . . . . . 6

1.3 LBD do RXR complexado com bigelovina . . . . . . . . . . . . . . 7

1.4 Alinhamento dos DBDs de ER, AR e GR . . . . . . . . . . . . . . . . . 9

1.5 Dímero de ER- $\alpha \ldots \ldots \ldots \ldots$. . . . . . . . . . . . . 10

1.6 Heterodímero de RAR- $\alpha$ e RXR $\ldots \ldots \ldots \ldots$. . . . . . . . 11

1.7 Método de predição de TFBSs proposto por Alamanova e colaboradores 20

3.1 Visão geral do TFBSAnalyzer . . . . . . . . . . . . . . . . . . 23

3.2 Visão da etapa de construção de complexos do TFBSAnalyzer. . . . . . . 24

4.1 Modelagem do DBD de RAR- $\beta$. . . . . . . . . . . . . . . . . . 32

4.2 Qualidade do modelo de DBD para RAR- $\beta$. . . . . . . . . . . . . . 33

4.3 Modelagem do DBD de RXR . . . . . . . . . . . . . . . . . . 33

4.4 Modelagem do DBD de ER- $\alpha \ldots \ldots$. . . . . . . . . . . . 34

4.5 Distribuições de energia de ligação para os NRs modelos. . . . . . . . . . 35

4.6 Comparação das distribuições de energia dos NRs modelo . . . . . . . . 37

4.7 Alinhamento das sequências dos DBDs dos NRs modelo . . . . . . . . . . 37

4.8 Alinhamento das estruturas dos DBDs dos NRs modelo . . . . . . . . . . 38

4.9 Resultados experimentais para RAR- $\beta$. . . . . . . . . . . . . . 40

4.10 Varredura do RARE $\beta$ com um heterodímero de $\operatorname{RAR} \beta$ - RXR . . . . . . . . 41

4.11 Varredura das sequências mutantes de RARE- $\beta$ com um dímero dos DBDs de RAR- $\beta$ e RXR e espaçador DR5 $\ldots \ldots \ldots$. . . . . . . . . . 42

4.13 Porcentagem de predições corretas para $\operatorname{RAR} \beta$ - RXR . . . . . . . . . . . 48

4.14 Curva ROC das predições corretas para $\operatorname{RAR} \beta$ - RXR . . . . . . . . . . . . 49

4.15 Resultados experimentais obtidos para ER- $\alpha$. . . . . . . . . . . . . 50

4.16 Varredura do promotor vitERE com um dímero de ER- $\alpha$. . . . . . . . . 51

4.17 Varredura das sequências mutantes de vitERE com um dímero de ER- $\alpha$ e espaçador IR3 . . . . . . . . . . . . . . . 52

4.19 Porcentagem de predições corretas para ER- $\alpha$. . . . . . . . . . . . . . 63

4.20 Curva ROC das predições corretas para ER- $\alpha$. . . . . . . . . . . . . . . . 64

4.21 Comparação do desempnho entre as predições feitas com TRANSFAC e com o método proposto $\ldots \ldots \ldots \ldots \ldots 6$ 
4.22 Curvas ROC - TFBSAnalyzer x TRANSFAC . . . . . . . . . . . . 66

4.23 Distribuição de TFBSs humanos a partir de dados de ChIP-chip. . . . . . 70

4.24 Distribuição de TFBSs para ER- $\alpha$ no genoma humano . . . . . . . . . . . 71

4.25 Controle da distribuição de TFBS de ER- $\alpha$ no genoma humano . . . . . . 72

4.26 Caracterização de eventos de ligação genômica. . . . . . . . . . . . . . 73

4.27 Distribuição de sítios putativos de ER- $\alpha$, obtidos com o TFBSAnalyzer . . 73

4.28 Enriquecimento de sítios putativos para ER- $\alpha$ por região genômica. . . . 74

4.29 Enriquecimento de sítios putativos para ER- $\alpha$ por região para o gene

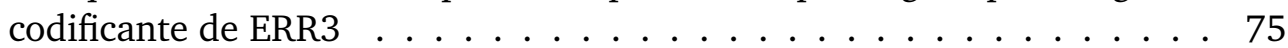

4.30 Quantidade de sítios putativos para ER- $\alpha$ nas regiões promotoras dos genes selecionados pela varredura do TFBSAnalyzer. . . . . . . . . . 75

4.31 Enriquecimento de sítios putativos para ER- $\alpha$ nas regiões promotoras dos genes selecionados pela varredura do TFBSAnalyzer. . . . . . . . . 76

4.32 Rede com genes selecionados e ER- $\alpha \ldots \ldots$. . . . . . . . . . 78

4.33 Modelagem do DBD de NHR-28, isoforma a . . . . . . . . . . . . . 79

4.34 Distribuição de energia de ligação para o NR de C. elegans. . . . . . . . . 80

4.35 Estruturas positivo verdadeiros $\ldots \ldots \ldots$. . . . . . . . 81

4.37 Estruturas negativo verdadeiros $\ldots \ldots \ldots$. . . . . . . . . . 83

4.39 Estruturas falso-positivos . . . . . . . . . . . . . . . . . . 85

4.40 Estrutura falso-negativo . . . . . . . . . . . . . . . . . . . . 86

4.41 Quantidade de ligações de hidrogênio nos complexos DNA-ER- $\alpha$. . . . . 88

4.42 Distribuições de quantidade e energia de ligações de hidrogênio nos complexos DNA-ER- $\alpha \ldots \ldots \ldots \ldots$. . . . . . . . . . . 89

5.1 Contribuições entálpicas e entrópicas para a energia livre de ligação . . . 92 


\section{Lista de Tabelas}

1.1 Exemplo de construção de uma PWM $\ldots \ldots \ldots$. . . . . . . . . 16

3.1 Exemplo de varredura com um monômero . . . . . . . . . . . . . . . . 28

3.2 Exemplo de varredura com um dímero simétrico . . . . . . . . . . . . . 29

4.1 Modelagem por homologia $\operatorname{RAR} \beta \ldots$. . . . . . . . . . . . . . . . 32

4.2 Resultados dos testes de normalidade shapiro-wilk com as distribuições de energia de ligação obtidas para os três NRs modelos. . . . . . . . . . 36

4.3 Resumo dos resultados obtidos para RAR- $\beta$. . . . . . . . . . . . . 47

4.4 Curvas ROC . . . . . . . . . . . . . . . . . . . . . . . . . 48

4.5 Comparação entre os resultados de Nguyen e as varreduras realizadas com um dímero de ER- $\alpha \ldots \ldots \ldots \ldots$. . . . . . . . . . . 62

4.6 Enriquecimento de TFs no conjunto de genes selecionados com o TFBSAnalyzer . . . . . . . . . . . . . . . . 77

4.7 Classificação dos resultados da comparação do TFBSAnalyzer com dados experimentais para ER- $\alpha \ldots \ldots \ldots \ldots$

A.1 Genes filtrados pelo enriquecimento de sítios na região promotora e reconhecidos pelo MetaCore. . . . . . . . . . . . . . . . . . 99 


\title{
Nomenclatura
}

\author{
AR Androgen Receptor \\ ChIP Chromatin Immunoprecipitation \\ CSS Core similarity score \\ DBD DNA-Binding Domain \\ DR Direct Repeat \\ ER Estrogen Receptor \\ GR Glucocorticoid Receptor \\ IR Inverted Repeat \\ LBD Ligand-Binding Domain \\ MEME Multiple Expectation Maximization for Motif Elicitation \\ MSS Matrix Similarity Score \\ NR Nuclear Receptor \\ PDB Protein Data Bank \\ PR Progesterone Receptor \\ PSSM Position-Specific Scoring Matrix \\ PWM Position Weight Matrix \\ RA Retinoic Acid \\ RAR Retinoic Acid Receptor \\ RARE Retinoic Acid Response Element \\ ROC Receiver Operating Characteristic
}


RXR Retinoic X Receptor

RXR Retinoid X Receptor

SELEX Systematic Evolution of Ligands by Exponential Enrichment

TF Transcription Factor

TFBS Transcription Factor Binding Site

TR Thyroid Hormone Receptor

TSS Transcription Start Site 


\section{Sumário}

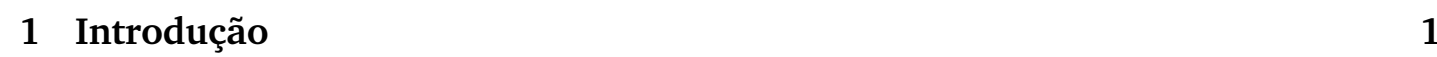

1.1 Motivação . . . . . . . . . . . . . . . . . . . . . 2

1.1.1 Métodos de predição de TFBSs . . . . . . . . . . . . . . 2

1.1 .2 Uso de receptores nucleares como modelo . . . . . . . . . . . . . . 3

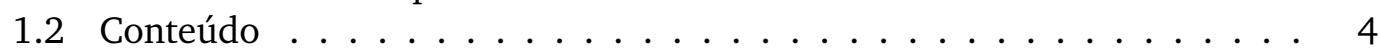

1.3 Estado da arte. . . . . . . . . . . . . . . . . 5

1.3.1 Famílias Estruturais de Fatores de Transcrição: Dedo de Zinco . . 5

1.3 .2 Receptores Nucleares . . . . . . . . . . . . . . 7

1.3.3 Identificação de TFBSs em sequências genômicas . . . . . . . . . 11

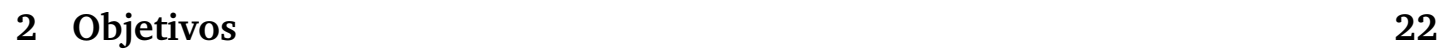

2.1 Objetivo Geral . . . . . . . . . . . . . . . . . . . . . . . . . . . 22

2.2 Objetivos Específicos . . . . . . . . . . . . . . . . . . 22

3 Métodos 23

3.1 Construção dos complexos . . . . . . . . . . . . . . . . . . . 23

3.1 .1 Modelagem por homologia . . . . . . . . . . . . . . . 24

3.1.2 Geração de todos os complexos e preparo para minimização . . . 26

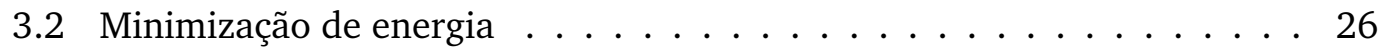

3.3 Cálculo da energia de ligação . . . . . . . . . . . . . . . . . . 26

3.4 Busca de TFBSs a partir da distribuição de energia de ligação . . . . . . 27

3.5 Validação dos resultados obtidos $\ldots \ldots \ldots \ldots$. . . . . . . . 28

$3.5 .1 \quad$ RAR- $\beta$ - RXR . . . . . . . . . . . . . . . . . . 29

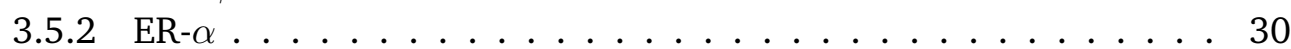

\begin{tabular}{|lll}
\hline 4 & Resultados & $\mathbf{3 1}$ \\
\hline
\end{tabular}

4.1 Construção dos complexos . . . . . . . . . . . . . . . . . 31

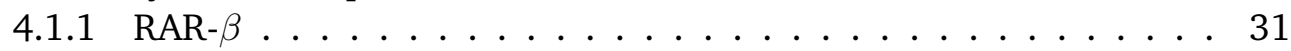

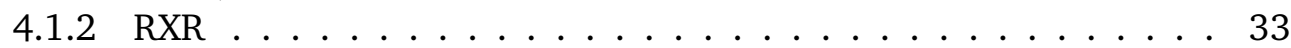

$4.1 .3 \quad \mathrm{ER}-\alpha \ldots \ldots \ldots \ldots \ldots \ldots \ldots$

4.2 Cálculo da energia de ligação dos complexos . . . . . . . . . . . . . . 34 
4.3 Comparação de TFBSs obtidos pelo TFBSAnalyzer com TFBSs obtidos de resultados experimentais gerados in vivo . . . . . . . . . . . . . 39

4.3.1 Comparação com resultados experimentais: RAR- $\beta$ - RXR . . . . 39

4.3.2 Comparação com resultados experimentais: ER- $\alpha$. . . . . . . 50

4.4 Comparação com resultados obtidos pelo TRANSFAC . . . . . . . . . . 63

4.5 Desenvolvimento de um programa para automatização do método . . . 66

4.6 Busca de TFBSs no genoma humano . . . . . . . . . . . . . . . 68

4.6 .1 Filtragem por exclusão de ilhas $\mathrm{CpG}$. . . . . . . . . . . . . . . 68

4.6.2 Filtragem pela distribuição de TFBSs ao longo do gene . . . . . . 69

4.7 Análise dos resultados da varredura genômica . . . . . . . . . . . . 76

4.8 Análise de um NR de C. elegans . . . . . . . . . . . . . . . . . 78

4.9 Análise estrutural dos complexos . . . . . . . . . . . . . . . 80

5 Discussão 90

5.1 Complexação de TFs com DNA in vivo e expressão gênica . . . . . . . . 990

5.2 Uso de outros fatores no cálculo do escore de ligação . . . . . . . . . . . . 91

5.2.1 Inclusão da entropia na classificação dos complexos . . . . . . . . 91

5.2.2 Inclusão da energia de ligações de hidrogênio na classificação

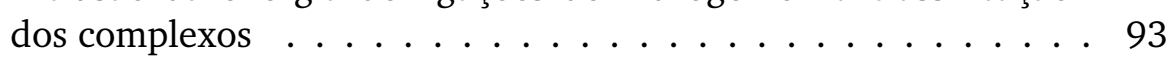

5.3 Desvantagens do algoritmo proposto . . . . . . . . . . . . . . . . 93

5.4 Vantagens do algoritmo proposto . . . . . . . . . . . . . . . . 994

5.5 Perspectivas . . . . . . . . . . . . . . . . . . . . 94

5.5 .1 Uso de outros fatores no cálculo do escore de energia . . . . . . . 94

5.5.2 Aplicação para TFs de outras famílias estruturais . . . . . . . . . 95

5.5 .3 Competição entre NRs por um mesmo TFBS $\ldots . . . . . . .95$

\begin{tabular}{lll}
\hline & Conclusões & 96
\end{tabular}

\begin{tabular}{ll}
\hline A Anexos & 98
\end{tabular}

\begin{tabular}{ll}
\hline Referências Bibliográficas & 100
\end{tabular} 


\section{Capítulo 1}

\section{Introdução}

Os projetos genoma têm fornecido uma grande quantidade de informações sobre a arquitetura gênica, bem como sobre a configuração física das regiões flanqueadoras (Alexander et al., 2010). Estas informações permitiram aumentar nosso conhecimento acerca de vários processos biológicos, dentre os quais o levantamento do transcriptoma de várias condições normais e patológicas nos mais distintos organismos (Hobert, 2008). O controle destes processos ocorre em diversos níveis, desde o controle da expressão gênica até as modificações pós-traducionais de proteínas. Sabemos que os mecanismos mais básicos de controle da expressão gênica são caracterizados pela interação entre fatores de transcrição (TF - Transcription Factors) e seus sítios de ligação ao DNA (TFBS - Transcription Factor Binding Site) . Fatores de transcrição são proteínas capazes de ligar-se a trechos de DNA, como promotores, enhancers e repressores. A região promotora geralmente é encontrada próxima ao início do gene que regula, enquanto sequências enhancers e repressoras podem ser encontrados em qualquer ponto do genoma, se aproximando dos genes através de modificações da estrutura da cromatina denominadas loopings (Shlyueva et al., 2014), como apresentado na Figura 1.1. Uma característica importante dos enhancers para a transcrição é a sua modularidade: eles agem de maneira aditiva e parcialmente redundante para a regulação da expressão gênica (Arnone and Davidson, 1997). Finalmente, a interação entre fatores de transcrição (TF - Transcription Factor) e seus sítios de ligação (TFBSs - Transcription Factor Binding Site) é específica, constituindo a base da regulação gênica no processo transcricional (Georges et al., 2010). Os fatores de transcrição modulam a maquinaria transcricional, levando à sua ativação ou inibição e, consequentemente, controlando o nível de expressão gênica (Lee and Young, 2000). 

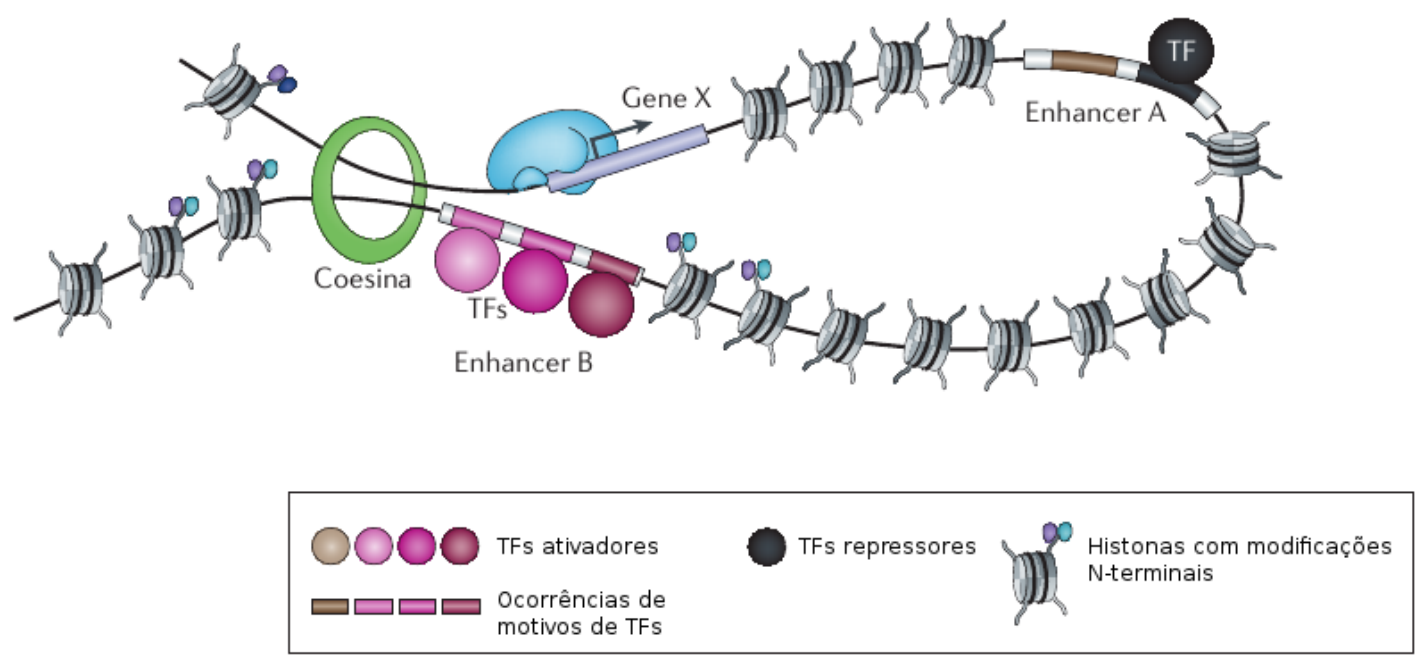

Figura 1.1: Ilustração das características de sequências enhancers e repressoras associadas à estrutura tridimensional da cromatina. Os TFs ativadores e repressores são capazes de reconhecer motivos apenas se estes estiverem em regiões abertas, ou seja, fora da estrutura dos nucleossomos. Está representada a estrutura de looping da cromatina, a qual é estabilizada por coesinas. No exemplo, o enhancer B é capaz de regular a transcrição do Gene X mesmo estando em uma região distante do promotor (ao qual está ligada a RNA polimerase, em azul). Esta situação é possível justamente por causa da estrutura de looping da cromatina. [Figura adaptada e traduzida de (Shlyueva et al., 2014).

\subsection{Motivação}

\subsubsection{Métodos de predição de TFBSs}

Devido à sua grande importância na regulação gênica e, portanto, em qualquer processo biológico, a predição de TFBSs é de grande interesse da comunidade científica. Foram desenvolvidos diversos métodos para realizar esta predição, tanto experimentais como computacionais. Alguns destes métodos são apresentados na seção 1.3 .3 . O desenvolvimento de métodos computacionais se justifica pois métodos experimentais são geralmente mais caros e demorados, considerando os avanços tecnológicas na área de computação atualmente. Os métodos computacionais mais empregados atualmente envolvem matrizes derivadas de alinhamentos, porém apresentam algumas limitações nas predições de TFBSs, muitas vezes perdendo sítios verdadeiros ou predizendo sítios inexistentes, além de serem altamente dependentes de experimentos custosos. Outra limitação reside no fato de estes estudos serem realizados frequentemente em organismos modelos. Existem também diversos fatores de transcrição que formam homo- ou heterodímeros para reconhecer seus TFBSs. Esta propriedade não é considerada pela maioria dos métodos de predição de TFBSs disponíveis, apesar de ser de extrema importância para a definição da especificidade da interação destes fatores de transcrição com DNA. Uma alternativa para a predição de TFBSs é o uso de métodos computacionais que não necessitem, a priori, de informações referentes ao sítio de ligação. As 
estruturas tridimensionais de fatores de transcrição, resolvidas por técnicas de cristalografia, tornam-se informações importantes quando associadas a técnicas de análise estrutural e a métodos termodinâmicos. Essa abordagem interdisciplinar pode auxiliar na compreensão de alguns dos aspectos relacionados à interação entre fatores de transcrição e o DNA, a qual é essencial para compreender a regulação gênica. A abordagem proposta neste trabalho consistiu em calcular a energia de ligação dos complexos após a minimização de energia destes e compará-los entre si. A partir desta análise, foram classificadas cada uma das sequências de DNA de acordo com sua estabilidade termodinâmica. Acreditamos que as sequências associadas aos complexos mais estáveis representem TFBSs com alta probabilidade de serem reais sítios funcionais para aquele fator de transcrição. Os modelos previstos computacionalmente foram comparados a dados experimentais disponíveis para estes receptores nucleares. Os dados gerados e as metodologias desenvolvidas neste projeto devem acrescentar uma sensível melhoria aos processos de predição de regiões regulatórias e consequentemente auxiliar no entendimento dos mecanismos envolvidos no processo de expressão gênica e de sua regulação.

\subsubsection{Uso de receptores nucleares como modelo}

Além de nosso interesse de pesquisa de desenvolver novos métodos computacionais para o entendimento da interação DNA-proteína, este projeto deverá contribuir de maneira significativa para o avanço de pesquisas envolvendo regulação gênica baseada em receptores nucleares realizadas por outros dois grupos experimentais do Laboratório Nacional de Biociências, coordenados pela Dra. Ana Carolina Miglorini Figueira e Dr. José Xavier-Neto. Assim, como modelos para testar a abordagem proposta, nós utilizamos três fatores de transcrição da superfamília dos receptores nucleares (NR), que vêm sendo estudados por estes grupos de pesquisa: RAR- $\beta$, RXR e ER- $\alpha$. A sinalização pelo ácido retinóico (RA - Retinoic Acid e seus derivados é responsável pelo controle de várias funções biológicas como, por exemplo, crescimento celular, diferenciação celular, formação da retina, desenvolvimento cardíaco e também relacionado a várias patologias como diabetes, obesidades, câncer, e doenças cardiovasculares (Ziouzenkova et al., 2007) A maquinaria que controla o metabolismo inclui as enzimas de síntese do AR (retinaldeído desidrogenase ALDH1A) e as enzimas de degradação do RA (Cyp26), que controlam a distribuição espaço temporal do RA durante a embriogênese (Cañestro et al., 2006). Depois de sintetizado, o RA atua ligando-se à receptores nucleares de ácido retinoico, (RAR - Retinoic Acid Receptor), que são ativados pelo all-trans ácido retinoico e 9-cis ácido retinoico (os dois principais isômeros do ácido retinoico) e receptores de retinoides X (RXR - Retinoic X Receptor) , que são ativados especificamente pela 9-cis ácido retinóico (Simões-costa et al., 2008). Para desempenhar seu papel como receptores nucleares, os RXRs formam heterodímeros com RARs reconhecendo uma sequência particular a partir da complementaridade espacial de suas cadeias laterais com a estrutura tridimensional do DNA. Essas regiões geralmente são compostas por 10 a 30 nucleotídeos, conhecidos como elementos responsivos a 
ácido retinoico (RAREs - Retinoic Acid Response Elements) , geralmente localizados próximo à região de início da transcrição do gene. O conhecimento da localização exata dessas regiões promotoras auxilia no entendimento da expressão gênica, sendo de extrema importância para a compreensão do funcionamento dos organismos e também das doenças que os afetam. O receptor de estrógeno $\alpha$ (ER- $\alpha$ ) é um NR de grande importância para o crescimento e a diferenciação em diversos tecidos, como o trato reprodutivo, glândulas mamárias e os sistemas nervoso central e esquelético. Existem evidências de que o estrógeno está envolvido também em processos patológicos como câncer de mama, câncer endometrial e osteoporose (Zhao et al., 2008). O câncer de mama é o mais frequentemente diagnosticado, sendo responsável por milhares de mortes por ano. Estima-se que em 2013, aproximadamente 232 mil mulheres serão diagnosticadas com câncer de mama, enquanto 40 mil mulheres serão vítimas fatais deste, apenas no Estados Unidos. (Siegel et al., 2013). Há evidências experimentais e epidemiológicas de que o receptor de progesterona (PR - Progesterone Receptor) está envolvido no desenvolvimento e progresso do câncer de mama. Dado que o PR é frequentemente utilizado como marcador da funcionalidade do ER- $\alpha$, este tem sido alvo de terapia contra a doença (Giulianelli et al., 2012).

\subsection{Conteúdo}

A seguir estão descritos a estrutura e o conteúdo deste documento:

- Capítulo 1; Introdução O restante deste capítulo dedica-se à descrição do estado da arte dos assuntos principais desta pesquisa:

- Apresentação das famílias estruturais de TFs, com ênfase na estrutura do dedo de zinco;

- Estudo dos receptores nucleares, com foco nos modelos deste trabalho;

- Estudo dos principais métodos de predição de TFBSs, tanto experimentais quanto computacionais.

- Capítulo 2 Objetivos: Apresenta o objetivo geral e os objetivos específicos deste trabalho de pesquisa.

- Capítulo 3 Métodos: Neste capítulo, o método de predição de TFBSs desenvolvido neste trabalho é abordado de maneira modular, composto por 4 etapas principais (construção de complexos, minimização de energia, cálculo de energia de ligação e busca de TFBSs), seguido pela definição do método de validação.

- Capítulo 4 Resultados: São apresentados os resultados de cada etapa descrita no Capítulo 3, para cada NR. Além da comparação com resultados experimentais, foi feita uma comparação do desempenho do TFBSAnalyzer com o TRANSFAC, uma ferramenta de predição de TFBSs amplamente utilizada atualmente. Em seguida 
explica-se o desenvolvimento de programas para automatização do método. A partir desta automatização, foi possível realizar uma busca de TFBSs no genoma humano por inteir. Em seguida, são apresentados os resultados calculados pelo TFBSAnalyzer para um receptor de C. elegans. Finalmente, a tentativa de utilizar outros fatores no cálculo do escore de ligação é apresentada e discutida.

- Capítulo5 5 Discussão: Este capítulo discute quatro assuntos:

- Cuidados a serem tomados ao utilizar o TFBSAnalyzer para predição de TFBSs in vivo e, principalmente, para a extensão ao estudo da regulação gênica por TFs.

- Desvantagens do TFBSAnalyzer

- Vantagens do TFBSAnalyzer

- Perspectivas

- Capítulo 6 Conclusões: Resume as principais conclusões alcançadas com esta pesquisa.

\subsection{Estado da arte}

\subsubsection{Famílias Estruturais de Fatores de Transcrição: Dedo de Zinco}

A interação dos fatores de transcrição com o DNA depende de uma estrutura relativamente pequena que seja estável e fique para fora do corpo da proteína, como um protuberância. Esta estrutura é o domínio de ligação ao DNA (DBD - DNA-Binding Domain). Foram descritas diversas famílias de DBDs baseadas na estrutura tridimensional do domínio, como hélice-volta-hélice, dedo de zinco, homeodomínio, zíper de leucina, etc. (Pabo and Sauer, 1992). Neste trabalho foram utilizados fatores de transcrição cujo DBD pertence à família dos dedos de zinco. Esta estrutura é formada por aproximadamente 30 resíduos de aminoácidos dispostos em forma de hélice e são estabilizados na base por um único íon de $\mathrm{Zn}^{2+}$, que por sua vez é coordenado por quatro resíduos (quatro cisteínas ou duas cisteínas e duas histidinas). Este íon mantém a estabilidade da estrutura e não participa da interação da proteína com o DNA (Nelson and Cox, 2005). A Figura 1.2 mostra a estrutura de um dedo de zinco. Os dedos de zinco podem ligar-se ao DNA através de repetições em tandem, e cada monômero reconhece sequências diferentes através da variação de alguns aminoácidos chaves na interação com o DNA, localizados na $\alpha$-hélice de reconhecimento do DNA. Como cada monômero funciona como um módulo independente, é possível utilizá-los em conjunto para reconhecer sequências de DNA maiores e, portanto, mais específicas. Esse DBD é encontrado em diversos organismos, como mamíferos, peixes e nemátodos (Klug, 2010). 
O DBD dos fatores de transcrição modelos deste trabalho contém dois dedos de zinco, um deles responsável por interagir com o DNA e o outro responsável por interagir com outro domínio da proteína, o qual não está representado na imagem. Dentre os fatores de transcrição que possuem DBDs da família dos dedos de zinco estão os receptores nucleares, superfamília à qual pertencem as proteínas utilizadas como modelos para o desenvolvimento deste trabalho.

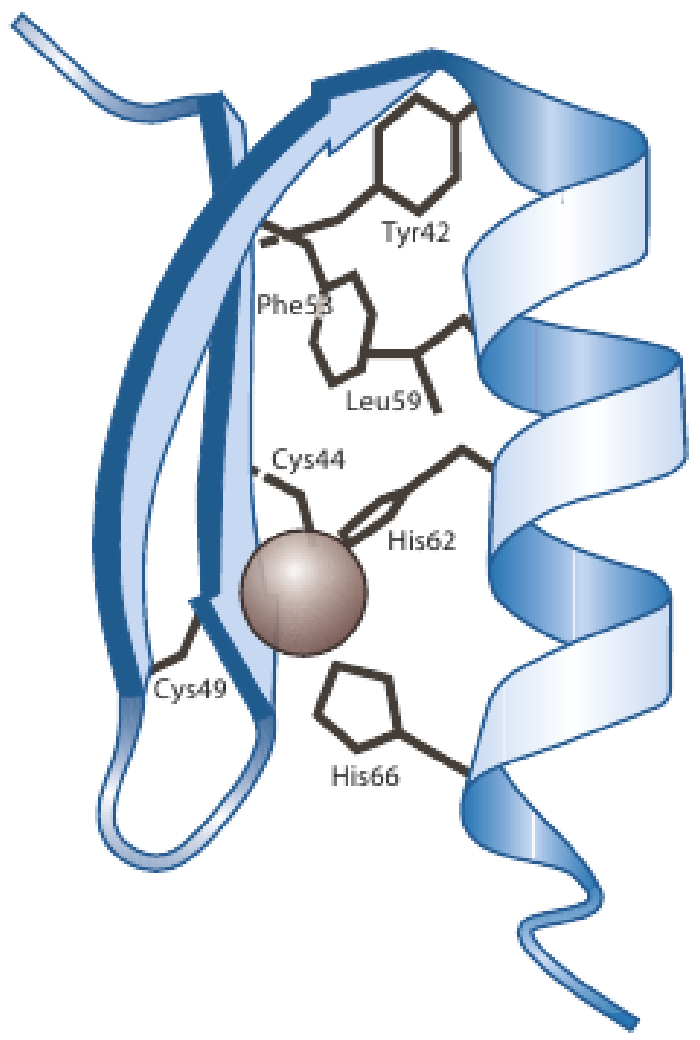

Figura 1.2: Estrutura de um motivo dedo de zinco. Em cinza vemos o íon de $\mathrm{Zn}^{2+}$, coordenado por duas cisteínas e duas histidinas. No caso dos fatores de transcrição cujos DBDs pertencem à família dos dedos de zinco, a hélice à direita interage com o DNA de maneira específica. Imagem extraída de (Klug, 2010). 


\subsubsection{Receptores Nucleares}

Os receptores nucleares (NR - Nuclear Receptor) constituem uma superfamília de fatores de transcrição ativados, em sua maioria, por ligantes, mais especificamente por pequenas moléculas lipofílicas. Os NRs controlam muitos dos processos reprodutivos, de desenvolvimento e metabólicos nos eucariotos, através da regulação de redes complexas de genes (Mangelsdorf et al., 1995), o que torna ainda mais interessante e necessário o estudo de sua interação com o DNA. A Figura 1.3 mostra o receptor de retinoide X (RXR - Retinoid X Receptor) complexado com seu ligante, a bigelovina.

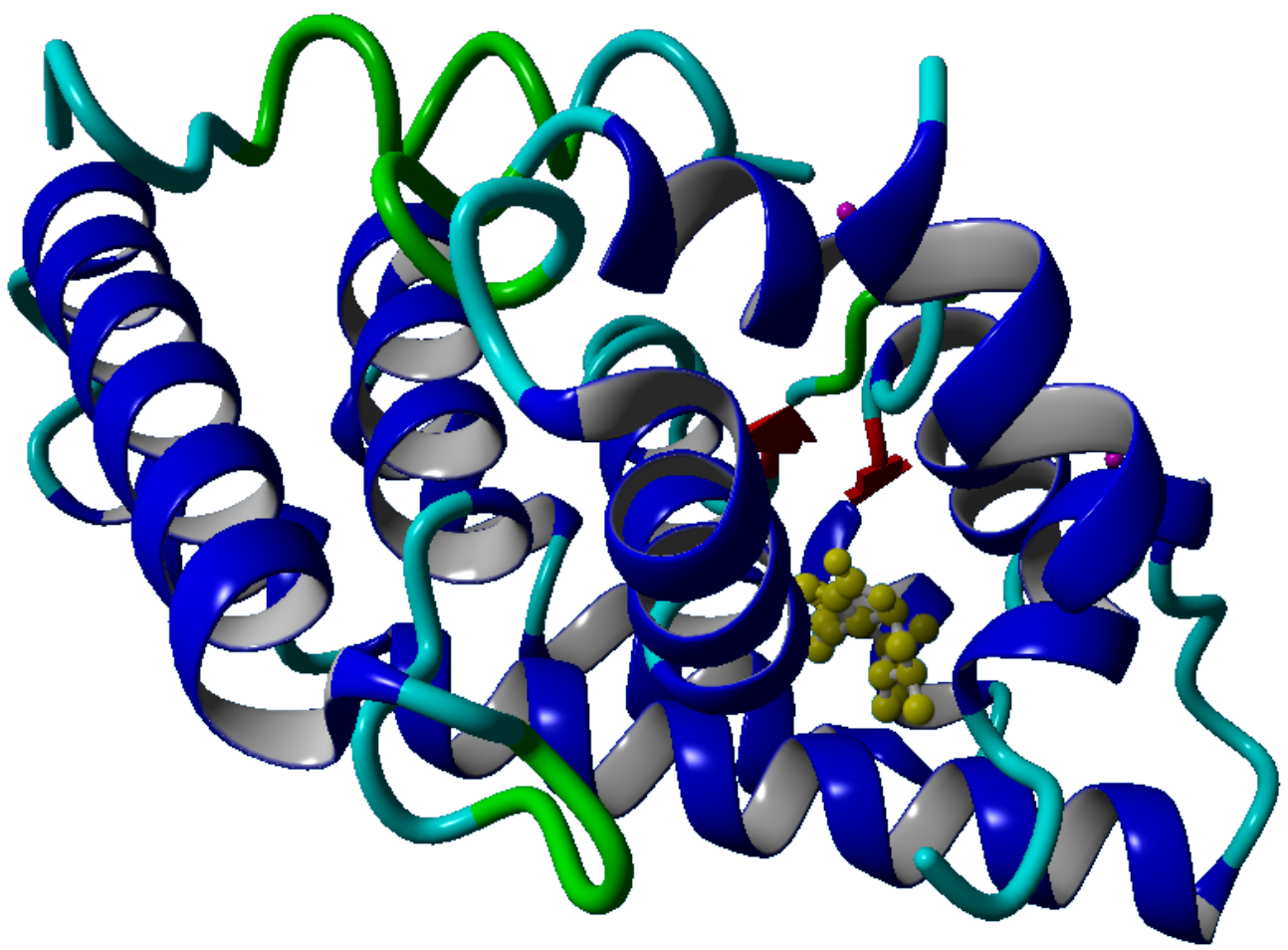

Figura 1.3: Estrutura do domínio de ligação ao ligante (LBD - Ligand Binding Domain) do RXR complexado com bigelovina (em amarelo). PDB ID 3OZJ

A superfamília dos NRs é dividida em três subfamílias, de acordo com o ligante reconhecido peloreceptor:

1. receptores de esteróides (classe I)

2. receptores de retinóides/tireóides (classe II)

3. receptores órfãos (classe III), a qual engloba todos os receptores cujos ligantes não são conhecidos. 
Os NRs são organizados similarmente em seis regiões de similaridade (Wahli and Martinez, 1991) e são caracterizados como superfamília pela presença de dois domínios principais: o domínio de ligação do ligante (LBD - Ligand-Binding Domain) e o DBD (Cotnoir-White et al., 2011). O LBD encontra-se na porção C-terminal dos receptores nucleares, é moderadamente conservado, possui uma região específica onde ocorre o acoplamento do ligante e é responsável por recrutar outras proteínas coativadoras da transcrição e mediar reações de dimerização ou tetramerização. Já o domínio DBD encontra-se na porção central da proteína e é responsável pela interação do receptor com o DNA (Birnbaumer et al., 1983), sendo suficiente para a determinação da especificidade da sequência de DNA reconhecida (Cotnoir-White et al., 2011). Este domínio é formado por uma sequência altamente conservada de 66 aminoácidos, contendo oito cisteínas que coordenam dois íons de zinco em arranjos tetraédricos (Mader et al., 1993). Estas estruturas são semelhantes a dedos de zinco (Figura 1.2). Estudos realizados com os DBDs do receptor de glicocorticóides (GR) e do receptor de estrógeno $\alpha$ (ER- $\alpha$ ) revelaram que muitos resíduos por todo o DBD interagem inespecificamente com o esqueleto do DNA, portanto com a função de aumentar a afinidade da interação, mas não a especificidade. Ao mesmo tempo foi descoberto que apenas alguns resíduos da primeira $\alpha$-hélice realizam contatos específicos com as bases do DNA, diretamente ou intermediados por água. Esta hélice foi então denominada hélice de ligação ao DNA (DNA binding helix) (Renaud and Moras, 2000). Dois destes resíduos são altamente conservados nos NRs (RR ou KR), enquanto os outros, pertencentes à região denominada P-box, são mais variáveis (Cotnoir-White et al., 2011). A Figura 1.4 mostra o alinhamento das sequências da hélice de ligação ao DNA do ER, do receptor de andrógeno (AR) e do (GR).

A grande semelhança entre os DBDs dos NRs resulta em uma baixa diversidade de motivos reconhecidos por estes TFs. Entretanto, grande parte deles associa-se ao DNA na forma de dímeros, o que aumenta a variabilidade dos TFBSs devido aos diferentes arranjos espaciais dos motivos. A segunda $\alpha$-hélice do DBD está envolvida não processo de dimerização e influencia, portanto, no tamanho do espaçador que separa os motivos reconhecidos por cada monômero, bem como na orientação destes no espaço (simétrica ou assimétrica). Existem três classes de sequências de DNA reconhecidas pelos receptores nucleares (ou elementos responsivos) (Renaud and Moras, 2000):

1. Reconhecidos por monômeros (Ex.: alguns receptores órfãos como NGFI-B).

2. Reconhecidos por homodímeros simétricos (Ex.: receptores de esteróides como ER- $\alpha$ ).

3. Reconhecidos por heterodímeros assimétricos (Ex.: receptores de não-esteróides, como RAR- $\beta$ e RXR).

A Figura 1.5 mostra um homodímero de ER- $\alpha$ complexado com DNA em um sítio do tipo 2. As sequências que representam o TFBS reconhecidos por cada monômero estão em vermelho, sendo um reconhecido na fita principal e outro na fita complementar. Em 


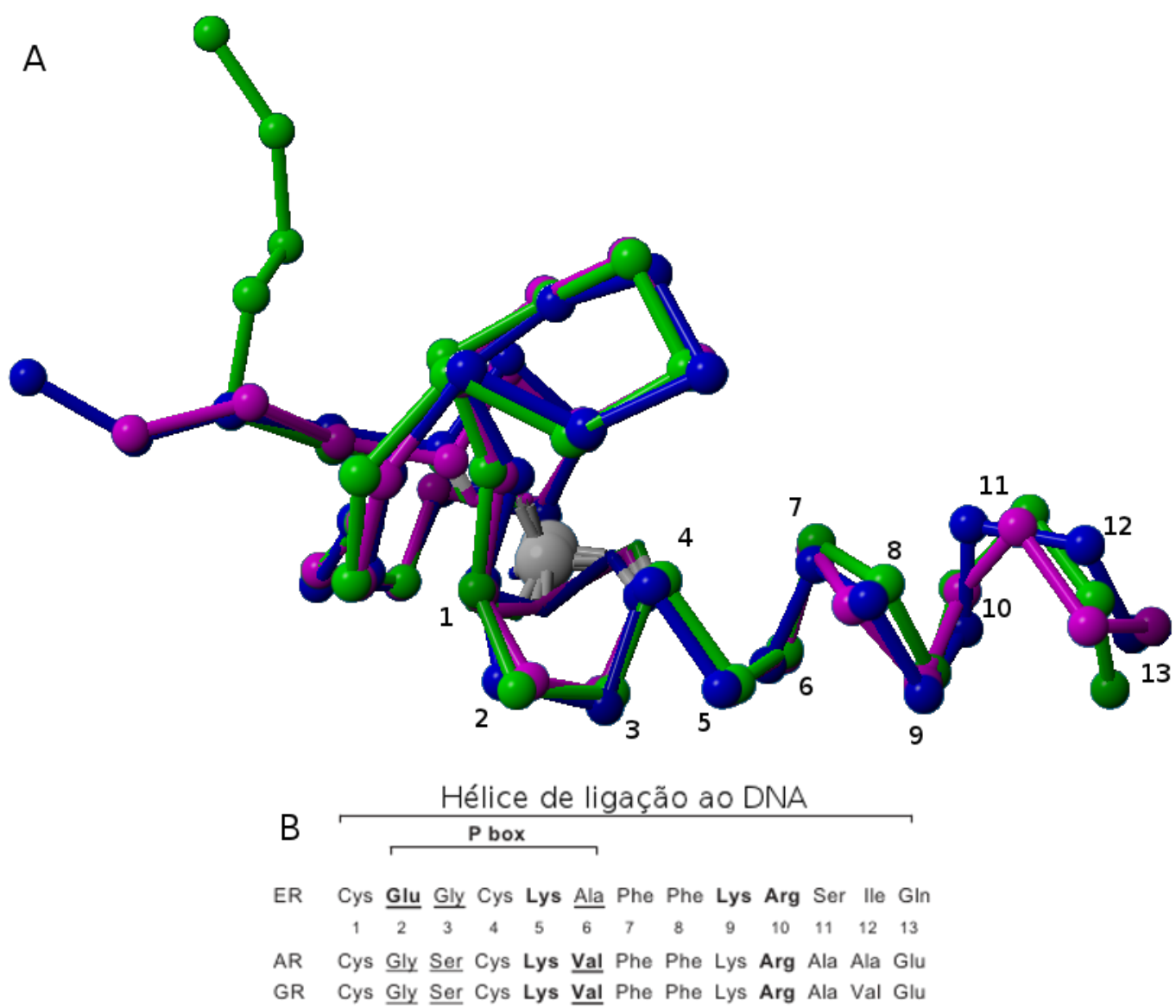

Figura 1.4: Alinhamento estrutural (A) e das sequências (B) das hélices de reconhecimento de ER (em rosa), AR (em azul) e GR (em verde). Os íons Zn2+ estão em cinza. Os aminoácidos em negrito interagem com as bases do DNA e são, portanto, importantes para a especificidade da interação. Os nucleotídeos dos P-box estão sublinhados. Imagem adaptada de (Nguyen et al. 2007) 
amarelo estão as sequências complementares às reconhecidas e em verde o espaçador IR3 (Inverted Repeat).

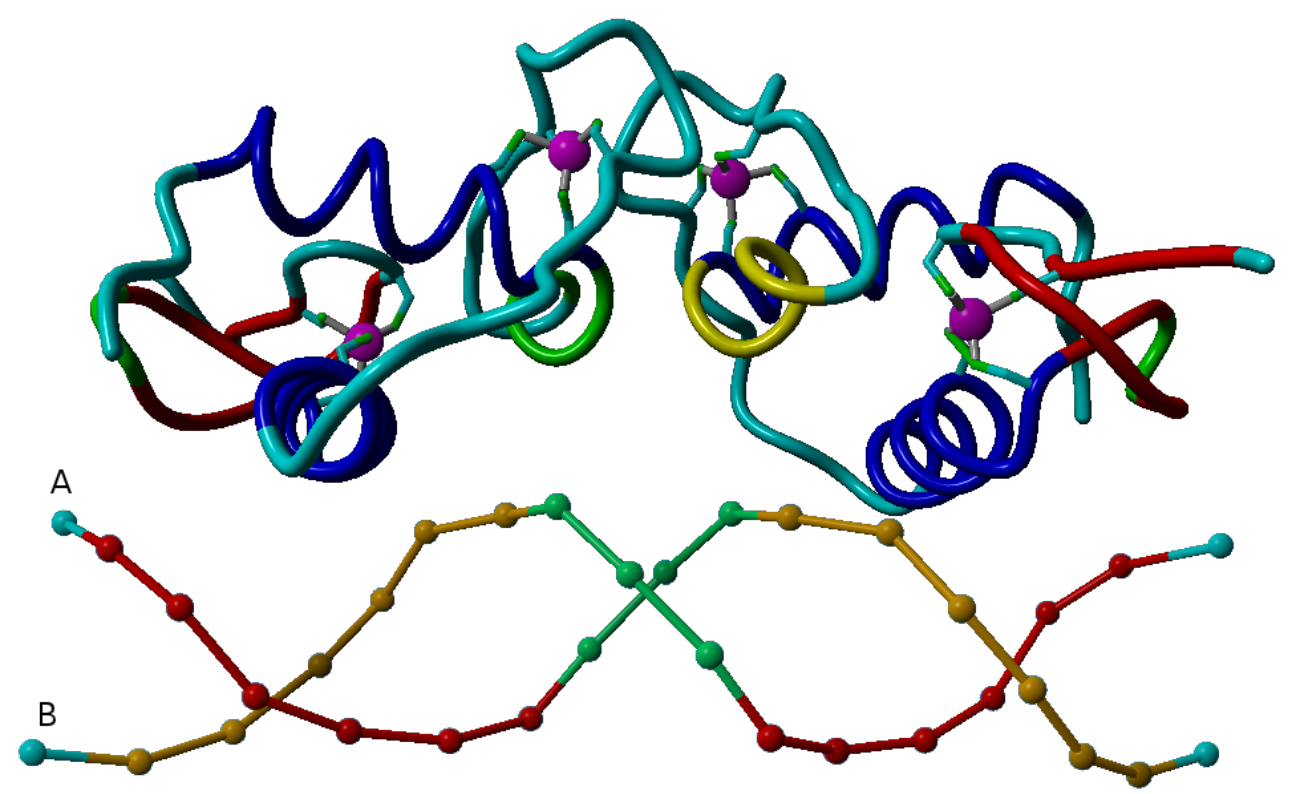

Figura 1.5: Estrutura dos DBDs de um dímero de ER- $\alpha$ complexados a uma fita de DNA. Essa estrutura está descrita no arquivo PDB de ID 1HCQ. Em vermelho: sítios de ligação de cada monômero; Em amarelo: sequência complementar aos sítios de ligação; Em verde: espaçador. Como os monômeros reconhecem seus sítios em fitas diferentes, são orientados de maneira simétrica. 
A Figura 1.6 mostra os DBDs do RAR- $\beta$ e do RXR complexados com DNA em um sítio do tipo 3. As sequências que representam o TFBS de cada monômero estão em vermelho. Em amarelo estão as sequências complementares e em verde o espaçador DR1 (Direct Repeat).

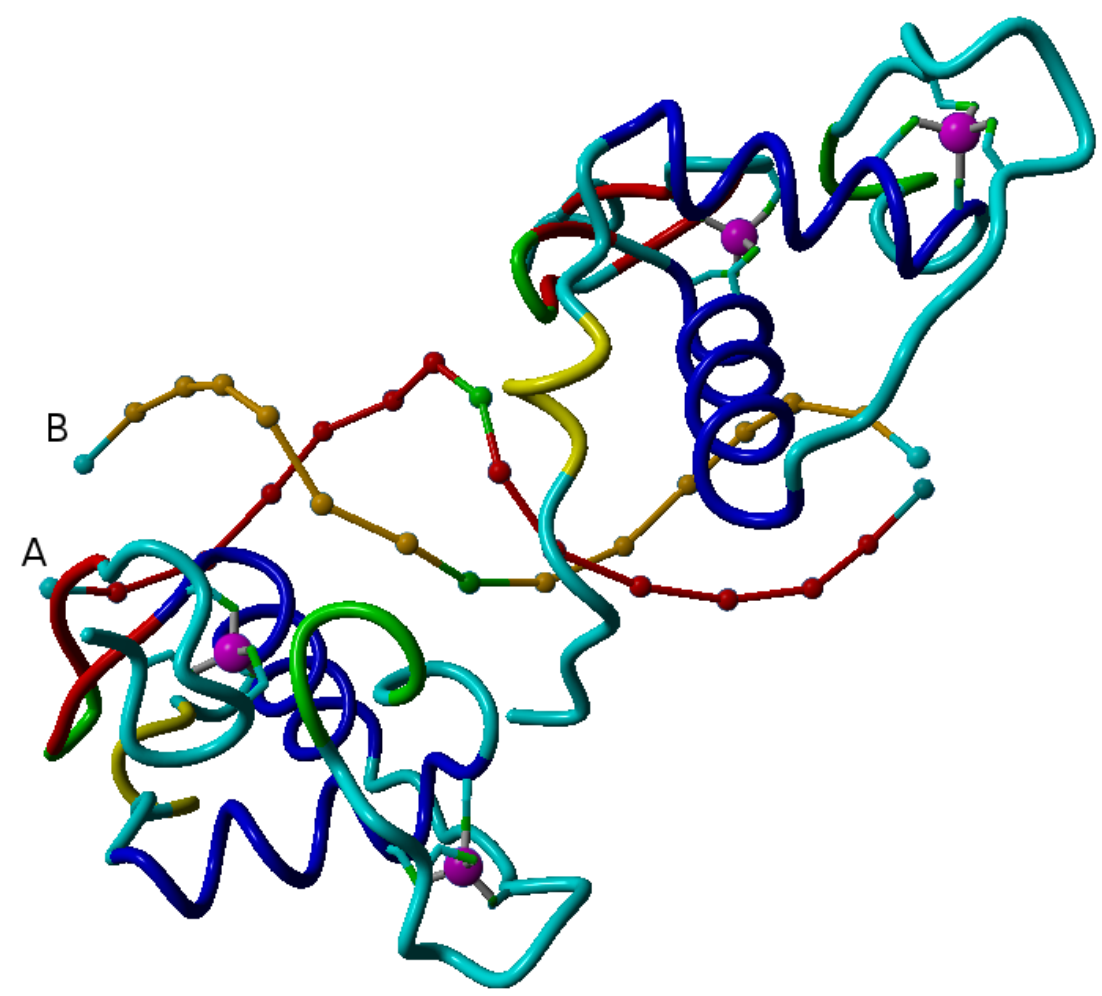

Figura 1.6: Estrutura dos DBDs de RAR- $\alpha$ (à esquerda) e RXR (à direita) complexados a uma fita de DNA. Essa estrutura está descrita no arquivo PDB de ID 1DSZ. Em vermelho: sítios de ligação de cada monômero; Em amarelo: sequência complementar aos sítios de ligação; Em verde: espaçador. Como os monômeros reconhecem seus sítios na mesma fita, são orientados de maneira assimétrica.

É importante observar que, dados dois monômeros, existem duas maneiras de ligálos a uma fita de DNA. A primeira delas é fazê-lo simetricamente, como é o caso do ER- $\alpha$ (Figura 1.5). Isso ocorre quando os monômeros reconhecem TFBSs em fitas diferentes. Como o reconhecimento depende do sentido da fita (5'3' ou 3'5'), o segundo monômero é rotacionado de $180^{\circ}$ em relação ao segundo, gerando um eixo de simetria entre os dois. A outra maneira de ligar os dois monômeros ao DNA é a que acontece para o heterodímero RAR- $\alpha$ e RXR. Neste caso, os dois monômeros são ligados ao DNA de maneira assimétrica (Figura 1.6), o que ocorre quando ambos os TFBSs ocorrem na mesma fita, portanto no mesmo sentido (5'3' ou 3'5'). O fato de trabalharmos apenas com uma sequência de DNA (em geral a da fita principal) é apenas uma simplificação, pois o DBD reconhece a fita dupla de DNA e não apenas uma delas. Essa distinção 
é importante para o algoritmo pois ao realizar a leitura de uma sequência de DNA, é necessário escolher os TFBSs de cada monômero na fita correta.

\subsubsection{Identificação de TFBSs em sequências genômicas}

\section{Métodos experimentais de predição de TFBSs}

Nesta seção serão abordados os métodos experimentais de determinação de TFBSs mais comuns: ChIP-chip, ChIP-Seq e SELEX.

\section{- ChIP-chip}

O método de ChIP-chip basicamente combina o método ChIP (Chromatin ImunoPrecipitation) e a técnica de análise de microarranjos, ou microarray (chip). Inicialmente, células de interesse são cultivadas e fixadas com formaldeído que induzirá a formação de ligações cruzadas (crosslinks) entre proteínas e DNA que estejam interagindo naquele momento. Em seguida, o extrato é sonicado para quebrar o DNA em fragmentos menores (geralmente próximos a $1 \mathrm{~kb}$ ). Para isolar e amplificar os fragmentos de DNA ligados ao fator de transcrição de interesse utilizam-se anticorpos específicos para este fator. Os anticorpos ficam fixos em uma superfície sólida e são encubados com a solução de complexos DNAproteínas. Em seguida é feita a lavagem da solução várias vezes, a fim de retirar todos os complexos cuja proteína não foi reconhecida pelos anticorpos. As ligações cruzadas são então revertidas e o DNA purificado, amplificado e marcado com moléculas fluorescentes. É preparado um microarranjo com diversos fragmentos de DNA, que idealmente representam o genoma completo do organismo em estudo. O DNA marcado é então hibridizado com o microarranjo e, uma vez que a posição de cada elemento do genoma é conhecida, é possível construir um mapa com todos os pontos do genoma em que aquele fator de transcrição interage com o DNA (Buck and Lieb, 2004). Este mapa pode ser analisado com ferramentas computacionais para a determinação das sequências que definem o TFBS do fator de transcrição. Dentre essas ferramentas podemos citar as bases de dados TRANSFAC (Matys et al., 2006) e JASPAR (Sandelin et al., 2004), os algoritmos MEME (Bailey and Elkan, 1994) e BioProspector (Liu et al., 2001), e o método proposto por Alamanova e colaboradores (Alamanova et al., 2010). O funcionamento destas ferramentas está descrito no item Métodos computacionais de predição de TFBSs desta seção. Apesar de ser capaz de fornecer um mapa de todos os TFBSs em um genoma, este método demanda muito tempo e apresenta um custo relacionado ao dispêndio de material entre US\$400 e US\$800 por microarranjo. (Park, 2009). Além disso, por ser um método complexo e com várias etapas, apresenta diversos pontos em que podem ocorrer erros experimentais, aumentando ainda mais o custo e o tempo necessário para realizá-lo. O algoritmo computacional proposto neste trabalho é muito mais rápido e menos 
custoso. Apesar de esta possibilidade não ter sido testada, seria possível utilizar nosso algoritmo para gerar um mapa de TFBSs por todo o genoma.

- ChIP-seq

Este método é semelhante ao ChIP-chip, baseando-se no mesmo processo de imunoprecipitação para selecionar as sequências de DNA de interesse. Após obter a solução de DNA de interesse, este é submetido a um sequenciamento massivo e paralelo (de onde recebe o nome 'seq') em vez de se utilizada a técnica do microarranjo, como no caso do ChIP-chip. Novamente é possível construir um mapa de TFBSs ao longo de todo o genoma para um determinado fator de transcrição. Este método é mais simples do que o ChIP-chip e apresenta uma resolução maior (um nucleotídeo para 30bp a 100bp do ChIP-chip, cuja resolução é dependente do microarranjo). Porém, este método é muito mais custoso, girando em torno de US $\$ 1000$ a US $\$ 2000$ (Park, 2009). Assim como no caso do ChIPchip, as sequências obtidas no sequenciamento podem ser submetidas a análise e busca por TFBSs pelas mesmas ferramentas computacionais citadas no item Métodos computacionais de predição de TFBSs desta seção. O método ChIP-seq apresenta as mesmas desvantagens que o ChIP-chip quando comparado ao algoritmo computacional proposto neste trabalho, tanto em relação ao custo de material e equipamentos quanto em relação ao elevado tempo de execução.

\section{- SELEX}

O método SELEX (Systematic Evolution of Ligands by Exponential Enrichment) tem como base teórica o processo da evolução, ou seja, a variação, seleção e replicação (Tuerk and Gold, 1990). Inicialmente, é gerada uma biblioteca aleatória de oligonucleotídeos (da ordem de $10^{15}$ sequências diferentes). Estes serão expostos ao fator de transcrição de interesse, e aqueles que não formarem complexos são excluídos através de cromatografia de afinidade, utilizando anticorpos específicos para o fator de transcrição em questão. As sequências restantes são então amplificadas e novamente submetidas ao processo de seleção. Quanto mais vezes este processo é repetido, mais rigoroso será o critério de seleção, ou seja, apenas sequências que apresentam uma energia de ligação muito alta com o fator de transcrição serão selecionadas. (Stoltenburg et al., 2007). Novamente, este método possui um custo e um tempo de execução muito maiores do que o algoritmo computacional proposto. Além disso, o nível de rigorosidade escolhido para a seleção de sequências poderia ser definido de maneira mais precisa através dos nossos resultados do que através do número de ciclos ao qual os oligonucleotídeos são submetidos no SELEX. 


\section{Métodos computacionais de predição de TFBSs}

Os métodos computacionais de predição de TFBSs disponíveis podem ou não depender da existência de uma biblioteca de sequências de DNA que são reconhecidas pelo fator de transcrição de interesse. Essas bibliotecas são obtidas através de métodos experimentais, como descrito no item anterior. Estão descritos a seguir diversos métodos computacionais de predição de TFBSs, de ambos os tipos, comumente utilizados ou recentemente propostos.

- Métodos computacionais dependentes de resultados experimentais prévios:

Todos os métodos descritos nesta seção têm a desvantagem de serem dependentes da realização prévia de métodos custosos, demorados e laboriosos como ChIP-chip e ChIP-seq. O algoritmo proposto neste trabalho depende apenas da estrutura do fator de transcrição de interesse, que pode ser encontrada em bases de dados com o PDB (Protein DataBank) ou criada através de diversos métodos computacionais de modelagem, como a modelagem por homologia. Portanto, nosso algortimo aumenta a escala em que pode ser realizada a predição e busca por TFBSs.

- TRANSFAC e JASPAR:

A predição de TFBSs em sequências de DNA é tradicionalmente feita empregandose matrizes ponderadas por posição (PWMs - Position Weighted Matrices) (Kulakovskiy et al., 2013). Essas matrizes são de ordem $4 \times \mathrm{N}$, onde $\mathrm{N}$ é o número de nucleotídeos da sequência de DNA. Cada célula da matriz apresenta valores relacionados à probabilidade de se encontrar um determinado nucleotídeo para uma dada posição da sequência de DNA. As PWMs permitem atribuir pontuações para sequências de DNA de N nucleotídeos. Definindo-se um valor de corte para estas pontuações, é possível classificar as sequências de DNA que obtiverem uma pontuação igual ou superior ao valor de corte como um TFBS do fator de transcrição em questão. 
A construção de PWMs é feita através do alinhamento de sequências conhecidas como TFBS de um mesmo fator de transcrição obtidas pelos métodos experimentais descritos anteriormente. Como exemplos de bases de dados de PWMs podemos citar o TRANSFAC (Matys et al., 2006) e o JASPAR (Sandelin et al., 2004). No caso do TRANSFAC, a busca por TFBSs a partir das PWMs é feita através da ferramenta Match (Kel et al., 2003), cujo funcionamento é explicado mais adiante. Já no caso do JASPAR (disponível em http://jaspar.genereg.net), a busca é realizada através de uma ferramenta web fornecida pelo mesmo grupo. Segue na Tabela 1.1 um exemplo fictício de construção de uma PWM a partir de um grupo de sequências de DNA reconhecidas por um determinado fator de transcrição: 
Tabela 1.1: Exemplo fictício de construção de uma PWM a partir de um grupo de sequências de DNA previamente alinhado.

Tomemos como base para a construção de uma PWM as seguintes sequências de DNA (previamente alinhadas):

\begin{tabular}{|c|c|c|c|c|c|c|c|}
\hline & \multicolumn{6}{|c|}{ Posição no TFBS } \\
\hline & & 1 & 2 & 3 & 4 & 5 & 6 \\
\hline \multirow{5}{*}{ Sítios } & 1 & A & $\mathrm{T}$ & $\mathrm{C}$ & G & A & $\mathrm{T}$ \\
\hline & 2 & A & $\mathrm{T}$ & G & G & A & $\mathrm{T}$ \\
\hline & 3 & $\mathrm{C}$ & $\mathrm{T}$ & $\mathrm{C}$ & G & $\mathrm{T}$ & A \\
\hline & 4 & A & G & A & $\mathrm{T}$ & $\mathrm{C}$ & $\mathrm{T}$ \\
\hline & 5 & A & G & $\mathrm{T}$ & $\mathrm{T}$ & $\mathrm{C}$ & $\mathrm{T}$ \\
\hline
\end{tabular}

A partir destes dados, obtém-se a seguinte PWM:

\begin{tabular}{|c|c|c|c|c|c|c|c|}
\cline { 3 - 8 } \multicolumn{2}{c|}{} & \multicolumn{6}{|c|}{ Posição no TFBS } \\
\cline { 3 - 8 } \multicolumn{2}{c|}{} & 1 & 2 & 3 & 4 & 5 & 6 \\
\hline \multirow{3}{*}{ Base } & A & 0,8 & 0,0 & 0,2 & 0,0 & 0,4 & 0,2 \\
\cline { 2 - 8 } & $\mathrm{C}$ & 0,2 & 0,0 & 0,4 & 0,0 & 0,4 & 0,0 \\
\cline { 2 - 8 } & G & 0,0 & 0,4 & 0,2 & 0,6 & 0,0 & 0,0 \\
\cline { 2 - 7 } & T & 0,0 & 0,6 & 0,2 & 0,4 & 0,2 & 0,8 \\
\hline
\end{tabular}

Em geral, alguns procedimentos matemáticos são adotados para evitar que a multiplicação destas probabilidades durante uma busca por TFBSs resulte em 0 . Tira-se então o logaritmo dos valores da matriz, à exceção dos valores 0 . Neste caso é necessário atribuir um valor que represente $\log (0)$, uma vez que este não existe e tende a $-\infty$. Tomando, por exemplo, -10 para simbolizar $\log (0)$, temos a seguinte matriz:

\begin{tabular}{|c|c|c|c|c|c|c|c|}
\hline & \multicolumn{6}{|c|}{ Posição no TFBS } \\
\hline & & 1 & 2 & 3 & 4 & 5 & 6 \\
\hline \multirow{4}{*}{ Base } & A & $-0,1$ & -10 & $-0,1$ & -10 & $-0,4$ & $-0,1$ \\
\hline & $\mathrm{C}$ & $-0,7$ & -10 & $-0,4$ & -10 & $-0,4$ & -10 \\
\hline & $\mathrm{G}$ & -10 & $-0,4$ & $-0,1$ & $-0,2$ & -10 & -10 \\
\hline & $\mathrm{T}$ & -10 & $-0,2$ & $-0,1$ & $-0,4$ & $-0,1$ & $-0,1$ \\
\hline
\end{tabular}

A busca por TFBSs a partir das PWMs contidas no TRANSFAC é feita através do algoritmo Match (Kel et al., 2003). Dada uma sequência de DNA e uma matriz do banco de dados, o algoritmo calcula duas pontuações, denominadas pontuação de similaridade de matriz (MSS - Matrix similarity 
score) e pontuação de similaridade de cerne (CSS - Core similarity score), ambas variando de 0 a 1 . O MSS mede a similaridade da sequência dada com a matriz por completo, enquanto o CSS mede a similaridade com o cerne da matriz, definido como as primeiras cinco posições consecutivas mais conservadas da matriz. São definidos dois valores de corte, um para cada pontuação e ambos variando de 0 a 1 . O algoritmo seleciona apenas as sequências cujas pontuações forem superiores aos valores de corte, os quais são fornecidos pelo usuário. Apesar de ser muito comum, o uso de PWMs apresenta sérias limitações, como a perda de informação sobre a interação entre os nucleotídeos da sequência, já que a construção da matriz considera a contribuição de cada nucleotídeo para a ligação independentemente. Adicionalmente, um número crescente de trabalhos tem demonstrado que a comparação direta de sequências de DNA algumas vezes falha em identificar segmentos ortólogos funcionais (Barrière, 2011), principalmente para os TFBS de baixa afinidade (ENCODE, 2012). Por último, o emprego direto de PWMs não considera o efeito da dimerização na interação proteína-DNA, efeito este crucial para a definição da especificidade de interação para o caso dos NRs.

- MEME:

O método computacional MEME (Multiple Expectation Maximization for Motif Elicitation ) (Bailey and Elkan, 1994) vem sendo amplamente empregado para a descoberta de TFBSs. Inicialmente, as N sequências de DNA contidas na biblioteca de interesse são quebradas em $\mathrm{n}$ subsequências de $\mathrm{W}$ bases (onde $\mathrm{W}$ é o número mínimo de nucleotídeos necessários para definir o TFBS). Em seguida, são gerados dois modelos probabilísticos do tipo mistura, um representando os TFBSs e outro representando todas as outras sequências (ou o background). O modelo dos TFBSs é definido pelos pa- 
râmetros $f_{i} j$, que representam a probabilidade de encontrar o nucleotídeo $a_{j}\left(\mathbf{A}=\left\{a_{1}=A, a_{2}=T, a_{3}=C, a_{4}=G\right\}\right)$ na posição i de um TFBS. Já o modelo do background é definido pelos parâmetros $f_{0} j$, que definem a probabilidade de encontrar o nucleotídeo $a_{j}$ em qualquer posição da sequência, ou seja, se uma sequência não é um TFBS, os nucleotídeos gerados em cada posição seguem a mesma distribuição probabilística. Definidos estes dois modelos, define-se o parâmetro $\lambda_{1}$, que representa a probabilidade de uma sequência pertencer ao modelo dos TFBSs. Pode-se definir também o parâmetro $\lambda_{2}=1-\lambda_{1}$, representando a probabilidade de uma sequência pertencer ao background. Dessa maneira, temos o seguinte cenário: o modelo dos TFBSs (com probabilidade $\lambda_{1}$ ) ou o modelo do background (com probabilidade $\lambda_{2}$ ) é escolhido pela natureza, e em seguida a sequência de W nucleotídeos é gerada a partir da distribuição de probabilidade que governa o modelo selecionado. A partir destas definições, todos os parâmetros citados são encontrados através do método de estimação por máxima verossimilhança (Expectation Maximization). Este método consiste em encontrar valores para os parâmetros que regem os modelos de maneira a obter a máxima verossimilhança para a biblioteca de interesse. Os parâmetros que governam o modelo de TFBSs compõem na verdade uma PWM, que pode ser utilizada por outros algoritmos (como MATCH) para buscar TFBSs em uma sequência de DNA de interesse.

Além da desvantagem da dependência de resultados experimentais demorados e caros de se obter, informações sobre a dependência dos nucleotídeos vizinhos nos TFBSs são perdidas, uma vez que os parâmetros de frequência usados no modelo de TFBSs são considerados independentemente. O algoritmo desenvolvido neste trabalho leva em conta estas informações ao realizar a minimização da energia dos complexos. Outra desvantagem deste 
método é o fato de sítios reconhecidos por dímeros não poderem ser identificados, ao contrário do que ocorre para o nosso algoritmo.

- BioProspector:

O método BioProspector (Liu et al., 2001), assim como o MEME, gera uma PWM para uma biblioteca de sequências de DNA reconhecidas por um determinado fator de transcrição, porém utiliza o método de amostragem de Gibbs para otimizar seus coeficientes em vez de estimação por máxima verossimilhança. Além disso, o BioProspector também utiliza um modelo de Markov para considerar o efeito da interação entre os nucleotídeos vizinhos na complexação com o fator de transcrição. Este método é capaz de levar em conta a complexação com homodímeros, recebendo como entrada o tamanho dos dois sítios e os limites de variação do tamanho do espaçador entre eles. O BioProspector está disponível em http://ai.stanford.edu/ xsliu/BioProspector.

Apesar de todas as melhorias, este método ainda depende da existência de uma biblioteca de sequências de DNA e também não permite a análise de TFBSs ligados por heterodímeros, como é possível fazer utilizando o algortimo desenvolvido neste trabalho.

- Métodos computacionais independentes de resultados experimentais: Alamanova e colaboradores desenvolveram um um novo método computacional de predição de fatores de transcrição (Alamanova et al., 2010), que utiliza informações relativas à estrutura tridimensional do complexo proteína-DNA para a construção de PWMs. Para um fator de transcrição cujo TFBS tem tamanho $\mathrm{N}$, o seguinte protocolo é seguido: a estrutura cristalográfica do complexo DNAproteína é obitdo em uma base de dados. São gerados $4 \times N+X$ complexos a partir de mutações realizadas no complexo inicial, onde $\mathrm{X}$ é um número ob- 
tido experimentalmente para tornar o resultado mais acurado e varia de 20 a 50. É calculada a energia de ligação de cada um dos $4 \times N+X$ complexos, baseada em um potencial estatístico. Os valores de energia de ligação são organizados em um vetor $\mathbf{b}$, chamado vetor de energias. As sequências utilizadas são traduzidas em uma matriz A denominada matriz de configurações, de colunas $A_{1}, A_{2}, \ldots A_{N}, C_{1}, C_{2}, \ldots C_{N}, G_{1}, G_{2}, \ldots G_{N}, T_{1}, T_{2}, \ldots T_{N}$, onde $N_{i}$ representa um nucleotídeo $\mathrm{N}$ na posição i da sequência. Cada linha da matriz corresponde a uma das sequências, e possui o número 1 nas células que correspondem aos seus nucleotídeos, e o número 0 nas outras células. Temos então o sistema linear $\mathbf{A} x=\mathbf{b}$, onde $x$ é o vetor de pesos da PWM que deseja-se encontrar. $\mathrm{O}$ sistema acima é resolvido pelo método dos mínimos quadrados (Figura 1.7).

Este método tem a desvantagem de utilizar apenas $4 \times N+X$ sequências de DNA para avaliar o comportamento de um fator de transcrição, um número muito pequeno se comparado ao total de $4^{N}$ sequências possíveis, principalmente pelo fato de $\mathrm{N}$ alcançar valores de até algumas dezenas, como mostrou o estudo estatístico com a base de dados TRANSFAC realizado em (Fogel et al., 2005), onde observou-se que $\mathrm{N}$ varia de 6 a 32. Outra desvantagem é a utilização de PWMs, que, como destacado anteriormente, perdem informações relativas ao efeito da interação entre nucleotídeos vizinhos na formação de complexos DNA-proteína. 


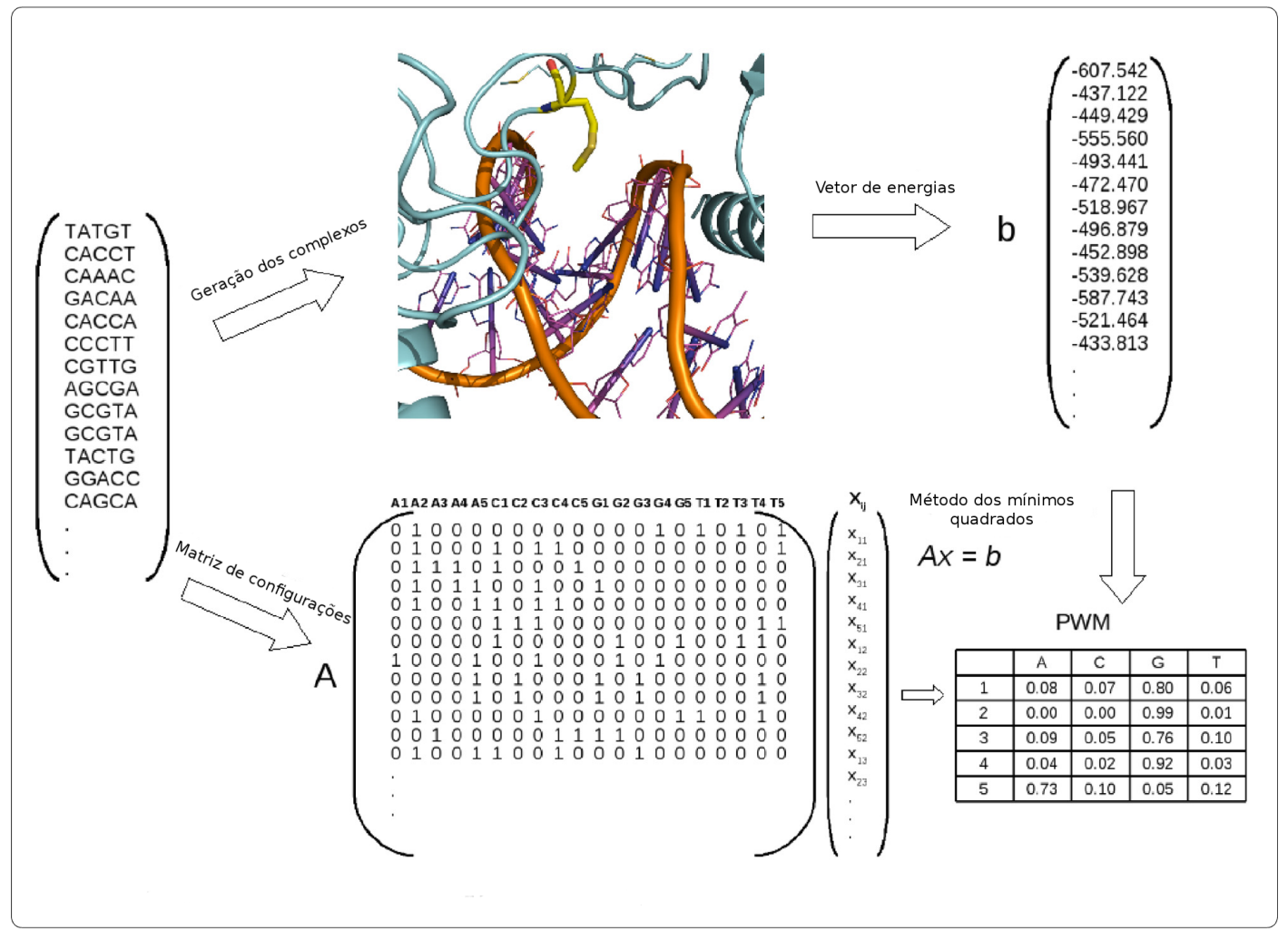

Figura 1.7: Ilustração do método computacional de predição de TFBSs desenvolvido por Alamanova. As sequências do vetor à esquerda correspondem às $4 \times N+X$ sequências utilizadas para determinar a PWM. Os complexos formados pelo fator de transcrição e estas sequências são gerados e têm sua energia de ligação calculada e anotada no vetor de energias b. Ao mesmo tempo, a matriz de configurações destas sequências A é construída. Ao resolver o sistema $\mathbf{A} x=\mathbf{b}$ através do método dos mínimos quadrados, obtém-se o vetor de pesos $\mathbf{x}$ da PWM desejada (Figura traduzida de (Alamanova et al. 2010)). 


\section{Capítulo 2}

\section{Objetivos}

\subsection{Objetivo Geral}

Desenvolver uma abordagem computacional capaz de utilizar aspectos termodinâmicos e estruturais da interação entre fatores de transcrição e DNA para a predição de TFBSs.

\subsection{Objetivos Específicos}

- Construir computacionalmente complexos entre os receptores nucleares RAR- $\beta$, RXR e ER- $\alpha$ e todas as possíveis sequências de DNA de seis pares de base e realizar experimentos de minimização de energia;

- Obter a distribuição da energia de ligação dos complexos minimizados para cada receptor nuclear utilizado como modelo;

- Propor e analisar novos métodos de classificação de sequências de DNA em TFBSs;

- Comparar os resultados obtidos na abordagem proposta com resultados experimentais de predição de TFBSs.

- Comparar o desempenho do método proposto com o do TRANSFAC. 


\section{Capítulo 3}

\section{Métodos}

As seções a seguir apresentam as técnicas utilizadas em cada etapa do TFBSAnalyzer. A Figura 3.1 mostra uma visão global do método proposto.

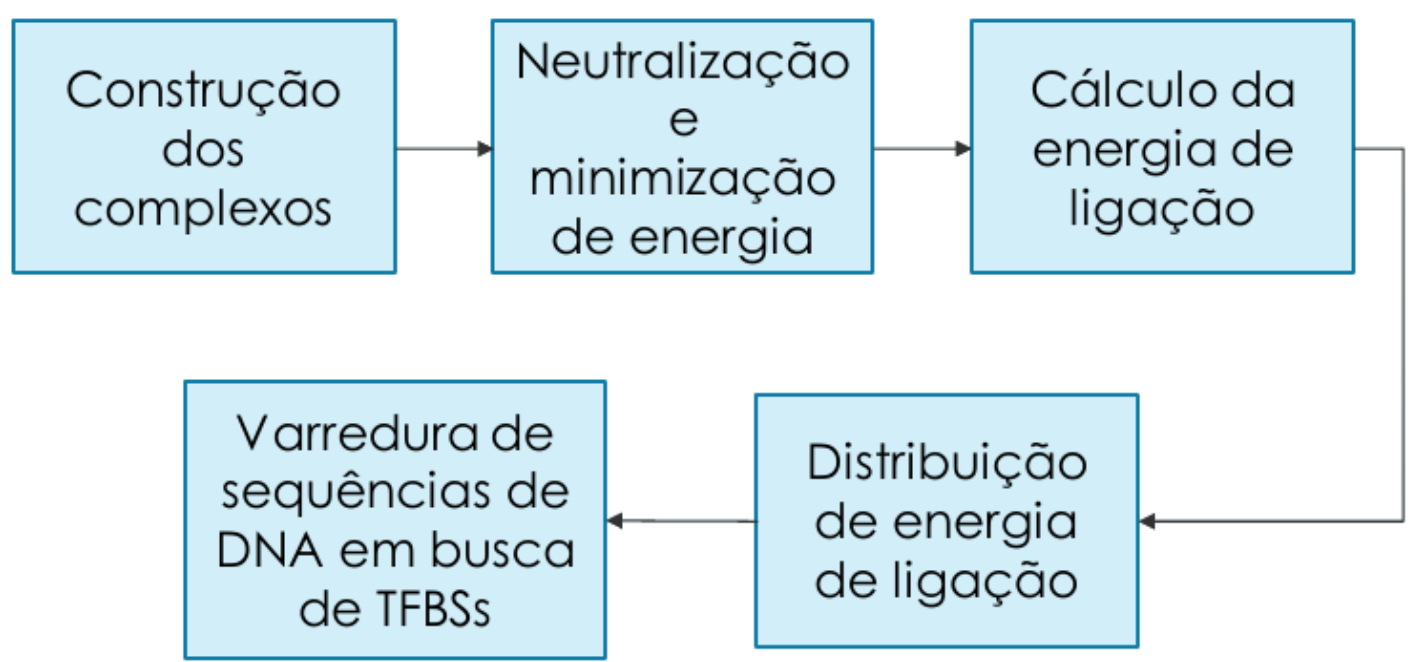

Figura 3.1: Visão geral do TFBSAnalyzer

\subsection{Construção dos complexos}

A Figura 3.2 apresenta uma visão geral da etapa de contrução dos complexos do TFBSAnalyzer. Para construir todos os $4^{6}$ (4096) complexos para cada receptor nuclear, foi necessário obter primeiramente um complexo do DBD do receptor com uma sequência de DNA qualquer. A partir dessa estrutura seria possível alterar cada um dos resíduos 
do DNA presente no complexo e gerar todas as 4096 sequências possíveis. Ao realizar uma busca na base de dados PDB (Protein Data Bank) foram encontradas as estruturas cristalográficas dos DBDs do ER- $\alpha$ e do RXR complexadas com uma dupla fita de DNA, com PDB IDs 1HCQ e 1DSZ, respectivamente. Porém, a estrutura do DBD de RAR- $\beta$ não estavam disponíveis, portanto foi necessário modelá-las. O método de modelagem escolhido foi a modelagem por homologia, uma vez que a estrutura dos DBDs dos receptores nucleares é muito similar (Bain et al., 2007) e existem várias delas resolvidas e publicadas no PDB.

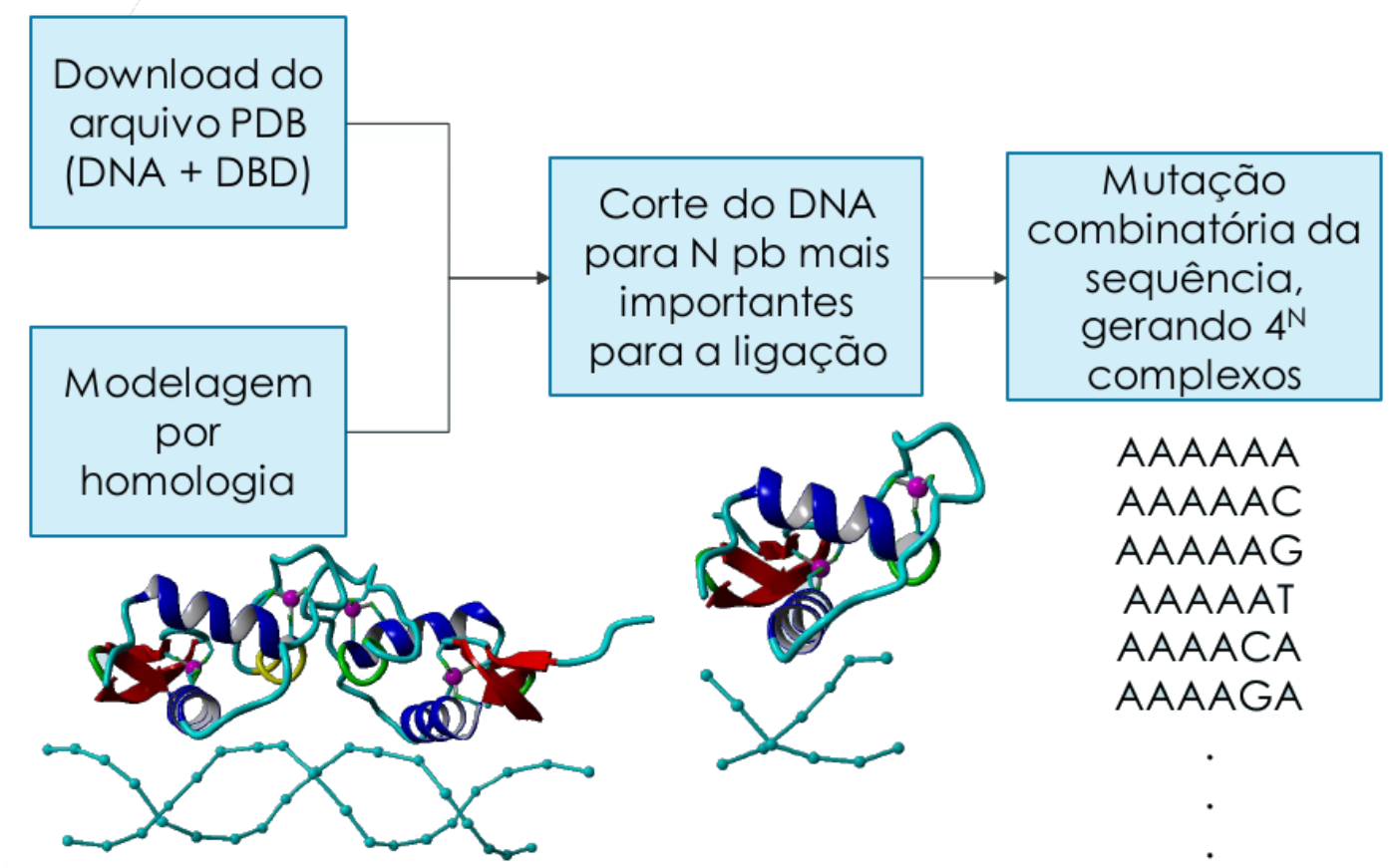

Figura 3.2: Visão da etapa de construção de complexos do TFBSAnalyzer.

\subsubsection{Modelagem por homologia}

O programa YASARA (Krieger et al., 2004) fornece uma ferramenta para realizar modelagem por homologia a partir de um arquivo fasta que contenha a sequência da proteína de interesse. O procedimento realizado pela ferramenta está descrito nos passos abaixo, retirados da documentação do programa:

- É realizado um experimento de PSI-BLAST (Altschul et al., 1997) com a sequência alvo, com 3 interações por padrão contra o banco UniRef90, a fim de construir uma matriz de pontuação por posição (PSSM - Position-Specific Scoring Matrix) utilizando sequências relacionadas. Este perfil é usado para buscar no PDB templates potenciais para a modelagem. 
- Os templates são classificados com base no escore do alinhamento e na qualidade da estrutura de acordo com o WHAT_CHECK (Hooft et al., 1996a) obtido na base de dados PDBFinder2 (Hooft et al., 1996b). Em seguida são construídos modelos para os $\mathrm{n}$ templates de maior escore, onde $\mathrm{n}$ é um parâmetro fornecido pelo usuário, de valor 5 por padrão.

- Se os templates contiverem ligantes (DNA, neste caso) estes são parametrizados e integralmente considerados no procedimento da modelagem por homologia, incluindo pontes de hidrogênios e outros tipos de interação com a cadeia peptídica. Solventes e moléculas buffer típicas são apagadas. Entretanto é possível alterar estes dois procedimentos modificando os parâmetros da ferramenta.

- Um gráfico da rede de rotâmeros da cadeia lateral é construído e o algoritmo Dead-End Elimination é utilizado para encontrar uma solução para o rotâmero inicial no contexto de uma função simples de energia de repulsão (Canutescu et al., 2003).

- Diversas conformações para os loops são testadas, em paralelo à etapa de reotimização das cadeias laterais para cada conformação.

- Os rotâmeros da cadeia lateral são otimizados considerando-se interações eletrostáticas e de knowledge-based packing interactions, bem como efeitos de solvatação.

- A rede de pontes de hidrogênio do modelo é otimizada, incluindo a dependência com o pH e ligantes.

- Uma minimização de energia com moléculas de solvente explícitas é realizada, utilizando os mais recentes campos de força. O resultado é validado para assegurar que o refinamento não moveu o modelo na direção errada.

- Após realizar todos os passos acima com cada template, são determinados indicadores da qualidade por resíduo para os modelos resultantes.

- Um modelo híbrido é construído, no qual regiões de baixa qualidade do modelo de melhor pontuação são iterativamente substituídas por fragmentos correspondentes de outros modelos.

- Um relatório com detalhes de todos os passos acima é escrito automaticamente.

- A qualidade por resíduo Z-score (média entre os Z-scores Dihedral, Packing1D e Packing3D) é multiplicado por -20, resultando no campo B-factor. Um B-factor menor ou igual a 0 indica um Z-score maior ou igual a 0 , ou seja, qualidade perfeita, enquanto um B-factor maior ou igual a 100 indica um Z-score menor ou igual a -5 , portanto uma péssima qualidade. 


\subsubsection{Geração de todos os complexos e preparo para minimização}

Após a construção do primeiro complexo, seja por modelagem por homologia ou simplesmente o uso da estrutura cristalográfica encontrada no PDB, este é usado como molde para geração de todos os outros 4095 complexos. Os nucleotídeos são mutados de maneira combinatória através do comando SwapRes do programa YASARA. Os complexos são então neutralizados com outra ferramenta, também do programa YASARA (Krieger et al., 2006), para dar início à minimização de energia.

\subsection{Minimização de energia}

Para remover superposições e corrigir a geometria covalente, os complexos tiveram suas energias minimizadas com o campo de força AMBER99, com corte de força $7.86 \AA$ e com o algoritmo Particle Mesh Ewald (Essman et al., 1995) para tratar interações a longa distância. Após a remoção de estresses conformacionais por uma curta minimização pelo método steepest descent, seguiu-se o método de simulated annealing (2fs para o passo de tempo, a velocidade dos átomos reduzida em 0.9 a cada 10 passos) até a convergência, ou seja, até que a energia seja alterada em menos de $0.05 \mathrm{~kJ} / \mathrm{mol}$ por átomo após 200 passos. A escolha do campo de força AMBER99 como campo de força adotado deve-se aos resultados obtidos por Wang, Cieplak e Kollman em dois conjuntos de biomoléculas: o primeiro com 34 moléculas muito bem estudadas pelo melhor modelo ab initio (GVB/LMP2) e experimentalmente; e o segundo com 55 moléculas, para as quais existem dados experimentais de alta qualidade. Em ambos os casos, os estudos com o AMBER99 forneceram resultados com erros médios absolutos (AAE - Absolute Average Error) menores do que aqueles cometidos por outros campos de força (MM3 e CHARMM). Além disso, alguns parâmetros torsionais envolvidos em ácidos nucleicos foram otimizados, resultando em uma melhor aproximação de estruturas de DNA do que os campos de força anteriores parm98 e parm94 (Wang et al., 2000).

\subsection{Cálculo da energia de ligação}

O cálculo da energia de ligação dos complexos minimizados pode ser feito através do comando BindEnergy do programa YASARA. Este comando calcula a energia potencial do fator de transcrição e do DNA separados a uma distância "infinita" (ou seja, desconsidera qualquer interação que poderia haver entre eles), e subtrai deste valor a energia potencial do complexo. O saldo de energia é a energia de ligação, e quanto mais positivo, mais favorável é a associação do fator de transcrição com o DNA. Todos os cálculos de energia são dependentes do campo de força utilizado, no caso o AMBER99. 
Para cada NR foram criados e minimizados 4096 complexos, representando todos os possíveis para um DNA de 6bps. Foi calculada a energia de ligação de cada complexo, e obtivemos, portanto, a distribuição completa de energia de ligação para cada NR modelo. Foi então desenvolvido um método computacional de busca de TFBSs em uma dada sequência de DNA, utilizando estes dados de energia como base para a classificação.

\subsection{Busca de TFBSs a partir da distribuição de energia de}

\section{ligação}

Uma possibilidade para buscar TFBSs a partir da distribuição de energia de ligação seria construir PWMs para cada receptor utilizando as sequências que apresentassem maior energia de ligação. Porém, como discutido anteriormente, ao utilizar uma PWM estamos perdendo informações sobre a dependência entre os nucleotídeos vizinhos do DNA, uma vez que são considerados independentes durante a construção da matriz. Para levar em consideração essas informações na busca por TFBSs, o seguinte método foi proposto:

- Dada uma sequência de interesse, varrê-la com uma janela de n pares de base (neste caso, $n=6$ ) e buscar a energia de ligação correspondente a cada passo na distribuição gerada anteriormente.

- As posições com energias mais altas em relação à distribuição completa do receptor em questão terão maior probabilidade de serem TFBSs.

Para facilitar a compreensão dos resultados da varredura, em vez de apresentar diretamente a energia de ligação de cada sequência utiliza-se um escore de 0 a 1 , que nada mais é do que a probabilidade de encontrar uma sequência com energia de ligação menor ou igual à energia de ligação da sequência em questão. Ou seja:

$$
S_{s e q}=s / 4^{n}
$$

onde seq é a sequência para a qual deseja-se calcular o escore, $S_{s e q}$ é o valor do escore calculado para a sequência $s e q, s$ é o número de sequências com energia de ligação menor ou igual à energia de ligação da sequência seq e $n$ é o tamanho da menor sequência de DNA que define o TFBS. O valor $4^{n}$ representa todas as sequências de DNA de $n$ pares de base que podem ser escritas, dado que o DNA é composto de 4 nucleotídeos diferentes. Dessa maneira, sequências com energias de ligação mais altas dentro da distribuição de um receptor terão escore mais próximo de 1 , enquanto as sequências energias de ligação mais baixas terão escore mais próximos de 0 . Segue na Tabela 3.1 um exemplo para facilitar o entendimento do método:

Grande parte dos receptores nucleares se ligam ao DNA na forma de dímeros, o que contribui muito para a definição da especificidade do reconhecimento dos sítios de 
Tabela 3.1: Exemplificação do protocolo de varredura de uma sequência de DNA com um monômero.

Desejam-se encontrar os prováveis sítios de ligação do receptor nuclear X na sequência de DNA abaixo:

A T C G A C G T A G

Primeiramente obtém-se a distribuição de energia de ligação para o DBD do receptor X.

Supondo que a menor sequência de DNA que define o TFBS para o receptor $\mathrm{X}$ tenha tamanho 6, teremos 4096 complexos possíveis. A varredura da sequência acima com uma janela de 6bps nos dá as seguintes sequências:

$$
\begin{array}{cccccccccc}
\text { A } & \text { T } & \text { C } & \text { G } & \text { A } & \text { C } & & & & \\
& \text { T } & \text { C } & \text { G } & \text { A } & \text { C } & \text { G } & & & \\
& & \text { C } & \text { G } & \text { A } & \text { C } & \text { G } & \text { T } & & \\
& & & \text { G } & \text { A } & \text { C } & \text { G } & \text { T } & \text { A } & \\
& & & & \text { A } & \text { C } & \text { G } & \text { T } & \text { A } & \text { G }
\end{array}
$$

Supondo que existam 10, 300, 200, 1000 e 4000 sequências de energia de ligação menor ou igual a cada umas das sequências apresentadas acima, respectivamente, o

$$
\begin{aligned}
& \text { A } \mathrm{T} C \mathrm{C} \quad \text { escore de cada uma será: } \\
& \begin{array}{lllllll}
\text { T C G A C G } & \rightarrow S=300 / 4096=0,073
\end{array}
\end{aligned}
$$

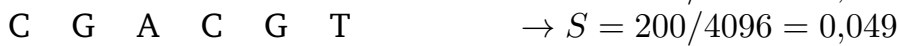

$$
\begin{aligned}
& \text { G } \quad \text { A } \quad \text { C } \quad \text { G } \quad \text { T } \quad \text { A } \quad \rightarrow S=1000 / 4096=0,244 \\
& \text { A } \quad \text { C } \quad \text { G } \quad \text { T } \quad \text { A } \quad \text { G } \rightarrow S=4000 / 4096=0,977
\end{aligned}
$$

ligação. Para considerar também este fator, a varredura das sequências foi feita com duas janelas de tamanho 6, separadas por um determinado número de nucleotídeos, denominados espaçador. Os escores obtidos em cada uma das janelas é então multiplicado, gerando um novo escore que também varia de 0 a 1 . A varredura também leva em conta se ambos os monômeros enxergam o mesmo plano da fita de DNA (como no caso do RAR- $\beta$ - RXR) ou se enxergam planos diferentes (como no caso do ER- $\alpha$ ). Os modos de ligação em dímero foram abordados na seção 1.3.2. A Tabela 3.2 mostra um exemplo de varredura de uma sequência com um dímero de ER- $\alpha$ :

\subsection{Validação dos resultados obtidos}

Foram selecionados dados experimentais de cada NR para validação dos resultados obtidos com o novo método proposto. As próximas seções listam os experimentos escolhidos e explicam como serão feitas as comparações. 
Tabela 3.2: Exemplificação do protocolo de varredura de uma sequência de DNA com um dímero que se liga de maneira simétrica.

Desejam-se encontrar os prováveis sítios de ligação do receptor nuclear ER- $\alpha$ na sequência de DNA abaixo:

A T C G A C G T A G C A G G T A

Primeiramente obtém-se a distribuição de energia de ligação para o DBD do receptor

ER- $\alpha$. Sabemos que sítio de ligação para este receptor tem tamanho 6. Utilizaremos

um espaçador de 3 nucleotídeos, ou DR3. Uma varredura com duas janelas de tamanho 6 espaçadas por 3 nucleotídeos nos dá as seguintes sequências (os sítios estão destacados em negrito)):
A $\mathrm{T}$
$\begin{array}{lll}C & G & A \\ C & G & A\end{array}$
$\begin{array}{llllllll}C & G & T & A & G\end{array}$
$\begin{array}{llllll}C & A & G & G & T\end{array}$
$\begin{array}{llllllllllllllll}\text { T } & \text { C } & \text { G } & \text { A } & \text { C } & \text { G } & \text { T } & \text { A } & \text { G } & \text { C } & \text { A } & \text { G } & \text { G } & \text { T } & \text { A }\end{array}$

Porém, sabemos que cada monômero de ER- $\alpha$ enxerga um plano diferente da fita de

DNA, logo o sítio de cada monômero está em uma fita diferente. Portanto, as

sequências consideradas para calcular o escore de ligação devem ser as seguintes:

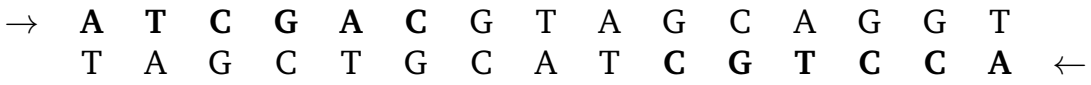

$$
\begin{aligned}
& \begin{array}{l}
S_{A T C G A C}=0,1 \\
S_{A C C T G C}=0,4
\end{array} \rightarrow S=S_{A T C G A C} \times S_{A C C T G C}=0,04 \\
& \begin{array}{lllllllllllllllll}
\rightarrow & \text { T } & \text { C } & \text { G } & \text { A } & \text { C } & \text { G } & \text { T } & \text { A } & \text { G } & \text { C } & \text { A } & \text { G } & \text { G } & \text { T } & \text { A }
\end{array} \\
& \begin{array}{llllllllllllllll}
\text { A } & G & C & \text { T } & \text { G } & \text { C } & \text { A } & \text { T } & \text { C } & \text { G } & \text { T } & \text { C } & \text { C } & \text { A } & \text { T } & \leftarrow
\end{array} \\
& \begin{array}{l}
S_{T C G A C G}=0,9 \\
S_{T A C C T G}=0,9
\end{array} \rightarrow S=S_{T C G A C G} \times S_{T A C C T G}=0,81
\end{aligned}
$$

Nesse caso, a segunda sequência é a que tem maior probabilidade de ser um TFBS real.

\subsubsection{RAR- $\beta$ - RXR}

Para analisar os resultados obtidos para os receptores RAR- $\beta$ e RXR foram utilizados os dados experimentais descritos em (Ruiz et al., 1991). O elemento responsivo a ácido retinóico RARE $\beta$ foi utilizado em um experimento de transativação com o receptor RAR- $\beta$, utilizando como proteína repórter a luciferase. Foram construídas 9 sequências a partir de mutações em trincas de nucleotídeos da sequência selvagem do RARE $\beta$. Estas sequências acima foram analisadas através do método proposto, e os resultados comparados qualitativamente, isto é, se houve ou não indução de luciferase, sem levar em conta o valor da atividade. 


\subsubsection{ER- $\alpha$}

O trabalho de Nguyen e colaboradores (Nguyen et al., 2007) com o receptor nuclear ER- $\alpha$ foi utilizado para comparação com os resultados obtidos pelo método proposto. Neste trabalho, foi utilizado o elemento de resposivo a estrógeno (ERE) derivado do promotor do gene vitelogenina A2, de Xenopus, cuja sequência foi extraída de (Klinge, 2001). Foram feitas mutações pontuais neste ERE, substituindo cada nucleotídeo das héxades pelas outras três possibilidades, totalizando 18 mutações. Os nucleotídeos mutados em cada sequência são simétricos em ambas as héxades. Com estas sequências foram realizados ensaios de mobilidade eletroforética (electrophoretic mobility assay) (Buratowski and Chodosh, 2001). Neste experimento, as sequências de DNA são marcadas com fluorescência e expostas à proteína de interesse. Em seguida é realizada uma corrida eletroforética com a solução, onde as sequências que sofreram complexação terão sua mobilidade reduzida, enquanto aquelas que não sofreram correrão uma distância muito maior no gel. Deste modo, verificou-se quais mutações inibiram a complexação com ER- $\alpha$. A fim de comparar nossos resultados com os ensaios de mobilidade eletroforética citados, as sequências mutantes foram varridas e as predições resultantes comparadas com os resultados experimentias. 


\section{Capítulo 4}

\section{Resultados}

\subsection{Construção dos complexos}

\subsubsection{RAR- $\beta$}

Como a estrutura do DBD de RAR- $\beta$ ainda não foi resolvida, foi realizada uma modelagem por homologia para obtê-la. A sequência modelada foi a do DBD de RAR- $\beta$ de Homo sapiens (referência NCBI: P10826). A Tabela 4.1 lista as estruturas escolhidas como templates para a modelagem do DBD do RAR- $\beta$, bem como dados sobre o alinhamento da sequência e a resolução da estrutura. Todos os templates apresentaram bom alinhamento com a sequência do DBD do RAR- $\beta$, com cobertura de $100 \%$ e e-valor muito próximo de 0 , além de apresentarem alta resolução de sua estrutura (2,4 Å ou melhor). Dessa maneira, a estrutura obtida para o DBD de RAR- $\beta$ é bastante confiável. Observa-se que todas as estruturas selecionadas são DBDs de NRs, o que é consequência da alta conservação dos DBDs desta superfamília de fatores de transcrição. A Figura 4.1 apresenta uma representação da estrutura resultante da modelagem por homologia. O programa YASARA realiza uma análise da qualidade da estrutura obtida, comparando-a com estruturas gold-standard através do índice Z-score. Este índice indica quantos desvios padrão a energia da estrutura obtida está distante da média de energia das estruturas gold-standard. Portanto, Z-scores muito negativos indicam estruturas com energia muito abaixo da média, portanto de má qualidade. A Figura 4.2 mostra a qualidade (Z-score) por resíduo obtida para o modelo final, comparada a uma estrutura obtida por raio-X com alta resolução. Observa-se que a região da hélice de ligação ao DNA em especial foi modelada com alta qualidade, o que é um ótimo resultado uma vez que ela é crucial para o bom desempenho do método proposto neste trabalho. O Z-score geral do modelo final foi de -0.2532 , o que pode ser considerado um resultado bom. 
Tabela 4.1: Templates utilizados na modelagem por homologia do DBD do RAR- $\beta$

\begin{tabular}{|c|l|l|c|c|c|l|}
\hline Template & $\begin{array}{l}\text { Score } \\
\text { total }\end{array}$ & $\begin{array}{l}\text { e-valor } \\
\text { (Blast) }\end{array}$ & $\begin{array}{l}\text { Escore do ali- } \\
\text { nhamento }\end{array}$ & PDB ID & Resolução & Cabeçalho do PDB \\
\hline 1 & 188,36 & $2 \cdot 10^{-22}$ & 379,0 & 1 DSZ-A & $1,70 \AA$ & $\begin{array}{l}\text { Structure Of The RxrRAR DNA- } \\
\text { Binding Domain Heterodimer In } \\
\text { Complex With The Retinoic Acid } \\
\text { Response Element Dr1 }\end{array}$ \\
\hline 2 & 125,71 & $9 \cdot 10^{-21}$ & 239,0 & $1 \mathrm{GA5}-\mathrm{E}$ & $2,40 \AA$ & $\begin{array}{l}\text { Crystal Structure Of The } \\
\text { Orphan Nuclear Receptor } \\
\text { Rev- Erb(Alpha)Dna-Binding } \\
\text { Domain Bound To Its Cognate } \\
\text { Response Element }\end{array}$ \\
\hline 3 & 122,50 & $3 \cdot 10^{-21}$ & 250,0 & 2 HAN-A & $1,95 \AA$ & $\begin{array}{l}\text { Structural Basis Of Heterodime- } \\
\text { ric Ecdysteroid Receptor Interac- } \\
\text { tion With Natural Response Ele- } \\
\text { ment Hsp27 Gene Promoter }\end{array}$ \\
\hline 5 & 121,41 & $7 \cdot 10^{-23}$ & 254,0 & 1DSZ-B & $1,70 \AA$ & $\begin{array}{l}\text { Structure Of The RxrRAR DNA- } \\
\text { Binding Domain Heterodimer In } \\
\text { Complex With The Retinoic Acid } \\
\text { Response Element Dr1 }\end{array}$ \\
\hline
\end{tabular}

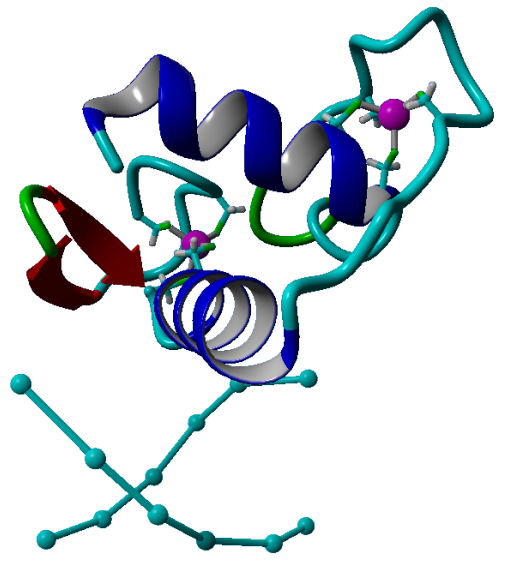

(a) Visão em laço

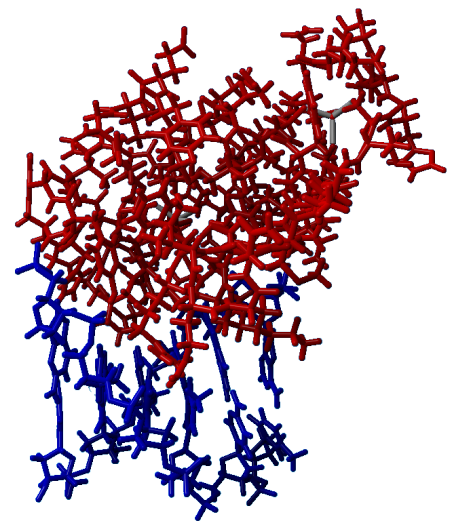

(b) Visão em bastão

Figura 4.1: Complexo RAR- $\beta$ e DNA, obtido através de modelagem por homologia. (a) DBD de RAR- $\beta$ em visão de laço. (b) DBD de $\operatorname{RAR} \beta$ em visão de bastão. 


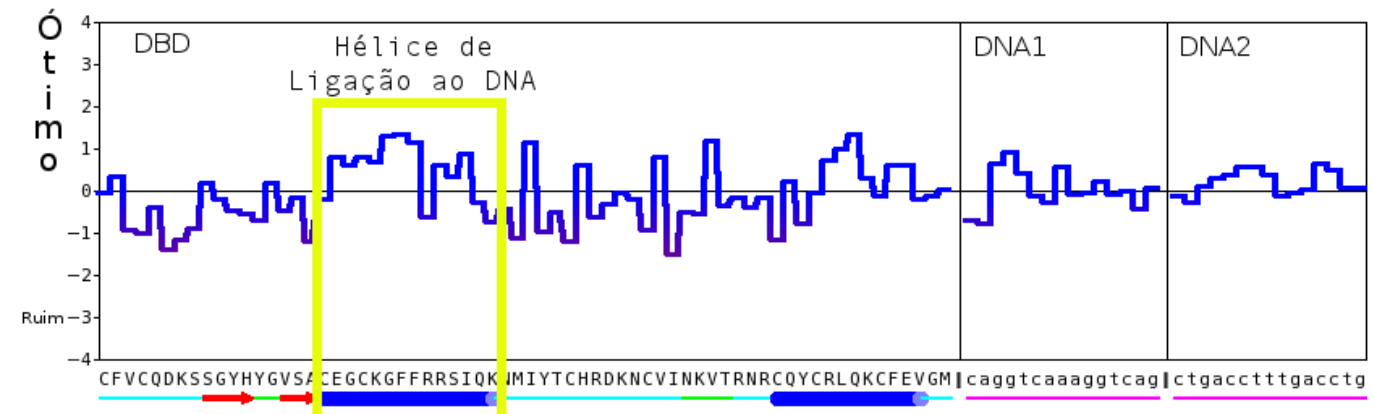

Figura 4.2: Qualidade (Z-score) por resíduo do modelo final obtido para RAR- $\beta$. As regiões em azul escuro no eixo das abcissas indicam as duas hélices dos dedos de zinco do DBD, sendo a hélice mais a $\mathrm{N}$-terminal correspondente à hélice de ligação ao DNA. A linha do gráfico varia de azul (boa qualidade) para vermelho (má qualidade). O quadro amarelo destaca a hélice de ligação ao DNA. O Z-score médio do modelo final foi de -0.2532 , considerado um resultado bom. Porém o Z-score médio na região da hélice de ligação ao DNA (a qual é a mais importante para o desenvolvimento deste trabalho) foi positivo.

\subsubsection{RXR}

Para o RXR, foi utilizada a estrutura descrita na entrada PDB de ID 1DSZ 1.6, a qual foi obtida por cristalografia, com uma resolução de 1,70A. Esta entrada PDB representa a estrutura de um dímero de RAR- $\alpha$ e RXR ligado a uma sequência de DNA, com espaçador DR1. O DBD de RAR- $\alpha$ foi removido da estrutura original e o DNA cortado para o TFBS do RXR. O complexo resultante está mostrado na Figura 4.3 abaixo:

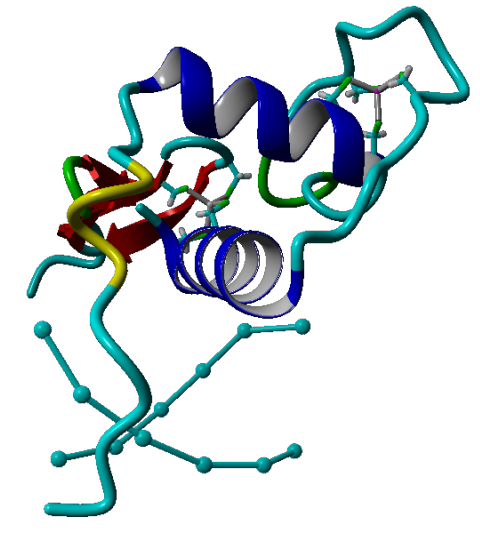

(a) Visão em laço

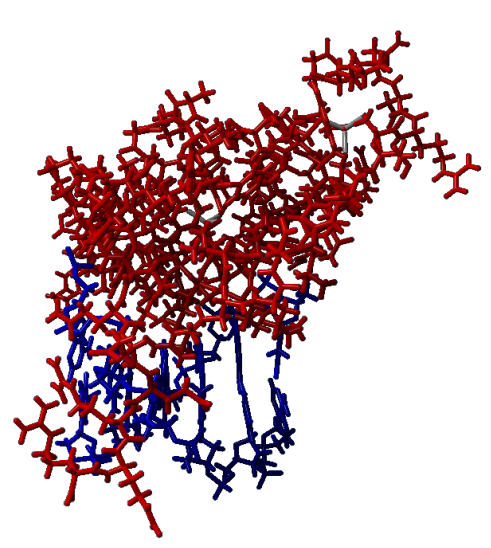

(b) Visão em bastão

Figura 4.3: Complexo RXR e DNA, obtido através de modelagem por homologia. (a) DBD de RXR em visão de laço. (b) DBD de RXR em visão de bastão. 


\subsubsection{ER- $\alpha$}

Para o ER- $\alpha$, foi utilizada a estrutura PDB de ID 1HCQ (Figura 1.5), a qual foi obtida por cristalografia, com uma resolução de $2,40 \alpha$. Este arquivo representa a estrutura de um dímero de ER- $\alpha$ ligado a uma sequência de DNA, com espaçador DR3. Para calcular a energia de ligação entre o DBD de ER- $\alpha$ e o DNA, o monômero ligado a downstream na sequência foi removido do complexo, bem como todos os nucleotídeos que não pertencem ao TFBS da esquerda, resultando no complexo da Figura 4.4 .

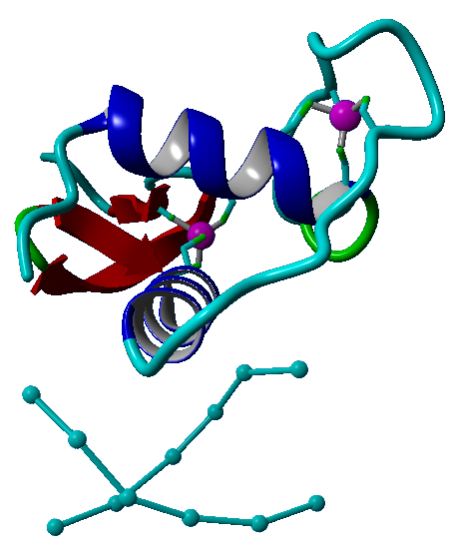

(a) Visão em laço

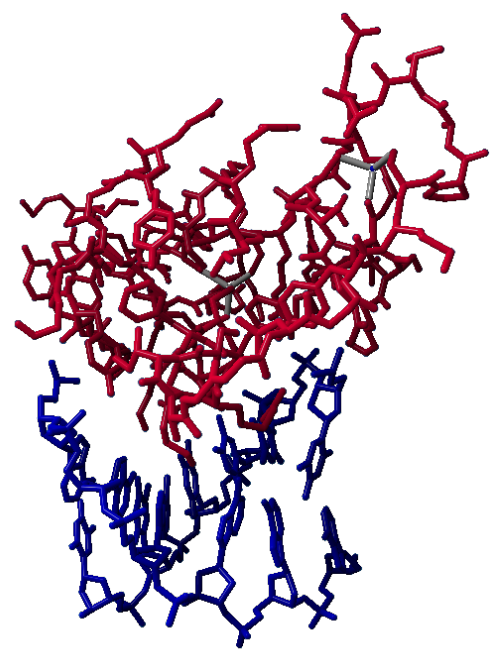

(b) Visão em bastão

Figura 4.4: Complexo ER- $\alpha$ e DNA, obtido através de modelagem por homologia. (a) DBD de ER- $\alpha$ em visão de laço. (b) DBD de ER- $\alpha$ em visão de bastão.

\subsection{Cálculo da energia de ligação dos complexos}

A distribuição da energia de ligação dos complexos de todos os modelos pode ser vista nos histogramas abaixo. Uma vez que todos os complexos possíveis foram analisados, temos as distribuições de probabilidade completas para cada receptor nuclear. Os resultados seguem na Figura 4.5 .

Nos histogramas,observa-se que a curva de densidade apresenta dados distribuídos simetricamente ao redor da média. Ao mesmo tempo, os gráficos quantil-quantil mostram pouco desvio da normalidade. Um teste shapiro-wilk confirma a normalidade dos dados, com resultados apresentados na Tabela 4.2. Portanto, pode-se afirmar que as distribuições de energia de ligação dos complexos obedecem uma distribuição normal, para a qual existem diversas ferramentas matemáticas que permitem a manipulação e o teste de dados estatísticos. Além disso, a região de extremo superior (maior energia de ligação) é a mais importante para a aplicação do método proposto, portanto o pequeno 


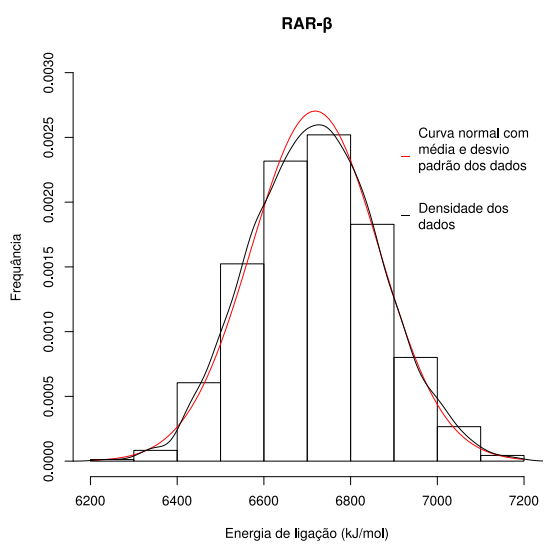

(a) RAR- $\beta$ - Distribuição

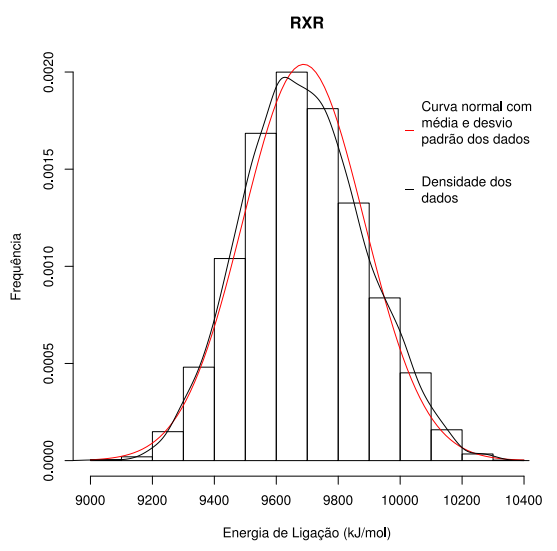

(c) RXR - Distribuição

ER- $\alpha$

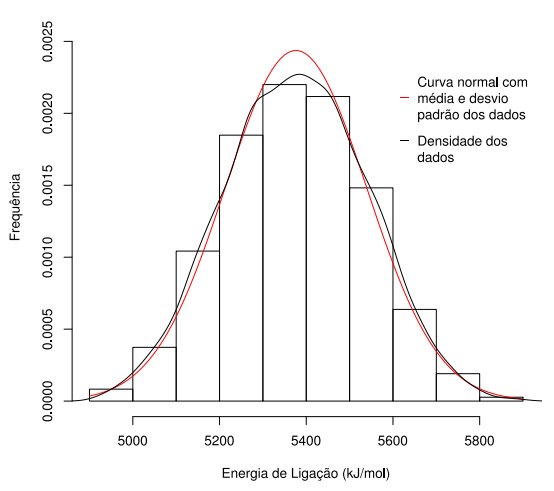

(e) ER- $\alpha$ - Distribuição

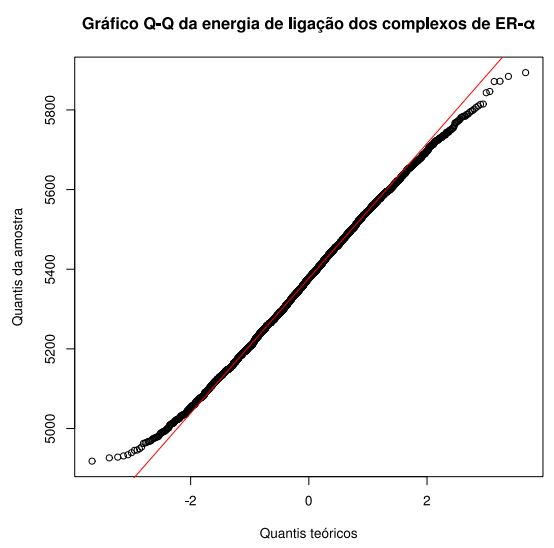

(b) RAR- $\beta$ - Gráfico QQ

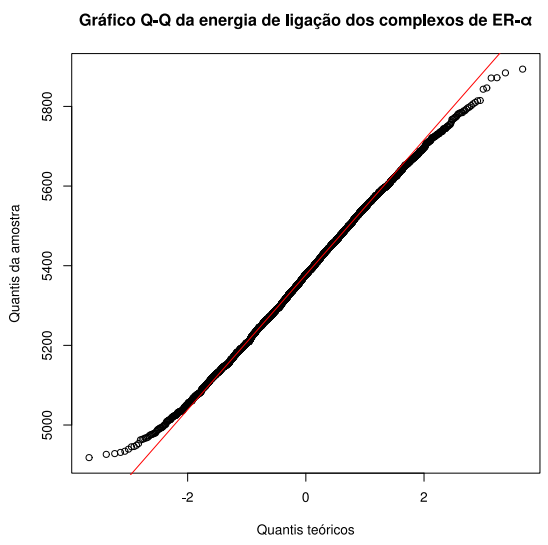

(d) RXR - Gráfico QQ

Gráfico Q-Q da energia de ligação dos complexos de ER- $\alpha$

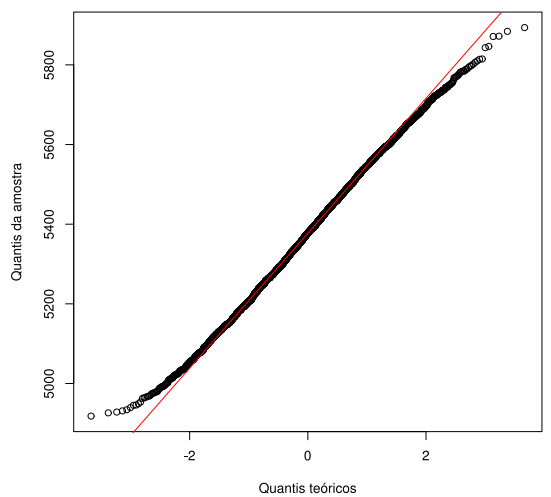

(f) ER- $\alpha$ - Gráfico QQ

Figura 4.5: Distribuição de energia de ligação e gráfico quantil-quantil para avaliação da normalidade dos dados. Histograma da energia de ligação dos complexos entre os fatores de transcrição e DNA de 6bp com a curva de distribuição de densidade para respectivamente RAR- $\beta$, RXR e ER- $\alpha$ (a,c,e) e respectivos gráficos quantil-quantil (b,d,f), onde se percebe a tendência da energia de ligação em seguir uma distribuição normal. 
desvio da normalidade significa uma maior acurácia para as predições de TFBSs. Em relação à amplitude das distribuições, obtivemos uma variação de energia de ligação de $945 \mathrm{kj} / \mathrm{mol}$ para RAR- $\beta, 1300 \mathrm{~kJ} / \mathrm{mol}$ para RXR e 975 para ER- $\alpha$. Se desconsiderarmos os dez pontos de menor energia de ligação da distribuição de RXR, obtemos uma amplitude de $1115 \mathrm{~kJ} / \mathrm{mol}$, portanto em geral a amplitude da distribuição de energia de ligação dos NRs modelo foi próxima de 1000kJ/mol, ou aproximadamente $240 \mathrm{kcal} / \mathrm{mol}$. Também é interessante observar que não houve sobreposição dos valores de energia obtidos em cada distribuição, como mostra a Figura 4.6 .

Tabela 4.2: Resultados dos testes de normalidade shapiro-wilk com as distribuições de energia de ligação obtidas para os três NRs modelos.

\begin{tabular}{|c|c|c|}
\hline Receptor Nuclear & W & p-valor \\
\hline RAR- $\beta$ & 0,9992 & $5,867 \mathrm{e}-2$ \\
\hline RXR & 0,9975 & $2,878 \mathrm{e}-6$ \\
\hline ER- $\alpha$ & 0,9983 & $1,739 \mathrm{e}-4$ \\
\hline
\end{tabular}

A Figura 4.7 mostra o alinhamento dos DBDs dos três NRs. Os resíduos na região amarela correspondem à hélice de ligação ao DNA, e os destacados em cinza correspondem aos principais resíduos responsáveis por definir a especificidade da interação com o DNA. Como discutido anteriormente, o DBD dos NRs é bastante conservado, especialmente a região da hélice reconhecedora. Esta conservação é refletida na estrutura tridimensional dos DBDs dos NRs, como é mostrado na Figura 4.8. Como os resíduos mais importantes para a especificidade da ligação (destacados em cinza) são praticamente os mesmos nos três NRs, eles reconhecem TFBSs muito semelhantes. Vale lembrar que a formação de dímeros para o reconhecimento de TFBSs é muito importante para determinar a especificidade da ligação destes fatores de transcrição. Porém, o resultado obtido na Figura 4.6 sugere que a competição pela interação com um TFBS in vivo também pode depender da afinidade da ligação, e não apenas da especificidade. Considerando apenas os resíduos destacados em cinza, a única diferença está em uma arginina do RAR-, a qual substitue uma lisina. Apesar de argininas formarem mais ligações de hidrogênio com o DNA, como observado experimentalmente em (Luscombe et al., 2001), este fato não é responsável pela variação da faixa de energia de ligação observada na Figura 4.6, pois tanto ER- $\alpha$ quanto RXR possuem uma lisina no lugar de uma arginina, e o RAR- $\beta$ aparece com um nível intermediário de energia. Isso reforça a hipótese de que a afinidade da ligação também é atingida através da interação inespecífica entre os outros resíduos do DBD e o esqueleto de fosfato do DNA. 


\section{Energia de ligação: ER- $\alpha$, RAR- $\beta$ e RXR}

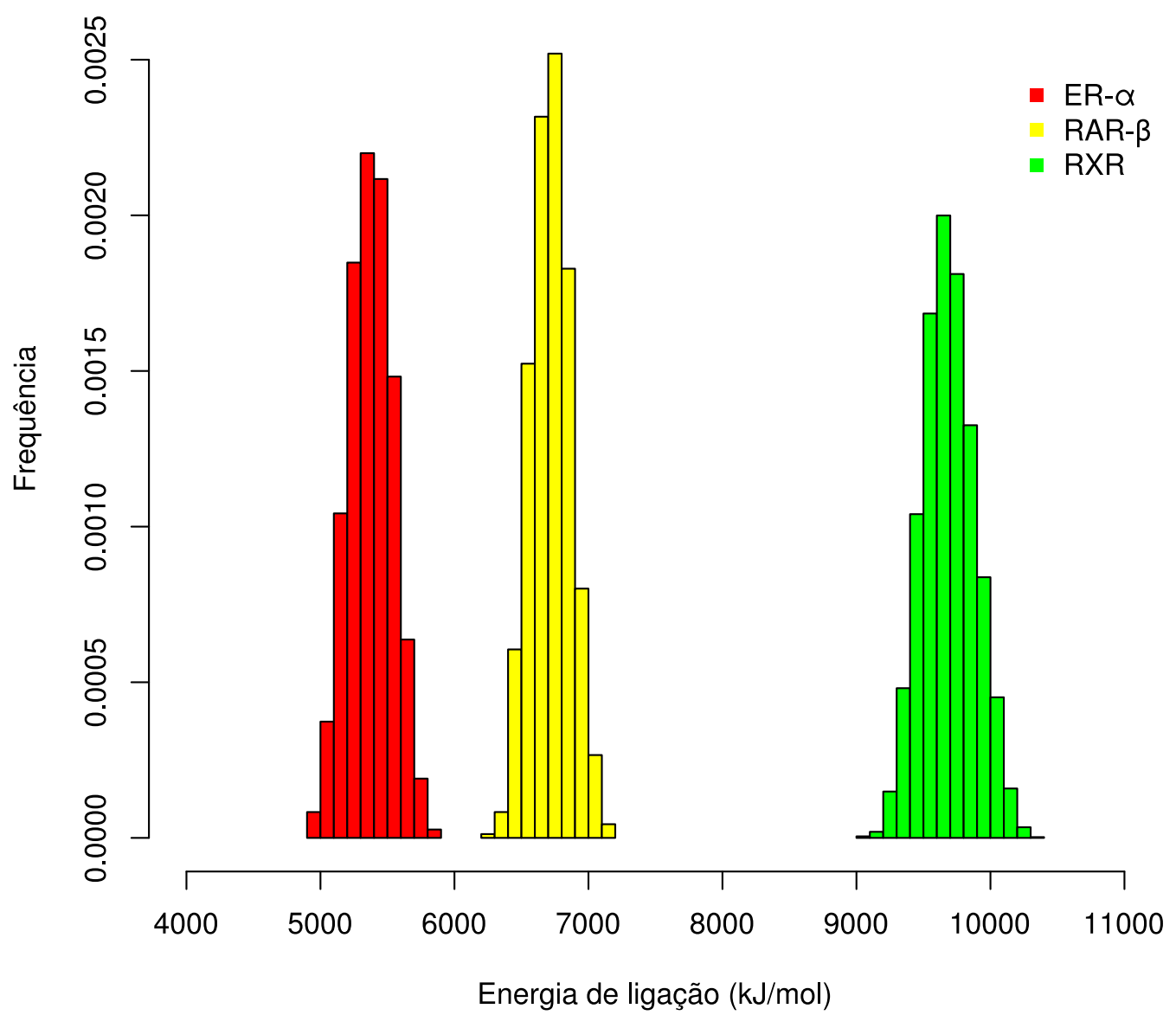

Figura 4.6: Comparação entre os histogramas de energia de ligação dos três NRs modelos deste trabalho. Nota-se que os DBDs, apesar de bastante similares em topologia, se ligam ao DNA com afinidades bastante diferentes.

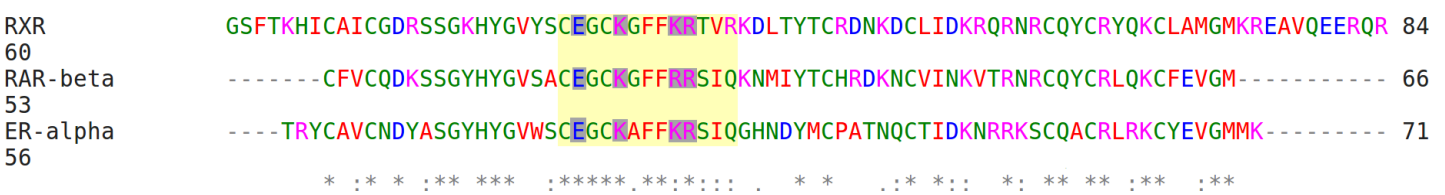

Figura 4.7: Alinhamento dos DBDs dos quatro NRs modelos deste trabalho. Os resíduos no fundo amarelo compõem a hélice de ligação ao DNA, e os resíduos destacados em cinza são os mais importantes para a determinação da especificidade da ligação ao DNA. O alinhamento foi realizado pela ferramenta web ClustalW2 (Larkin et al., 2007). A cor vermelha é usada para aminoácidos pequenos e hidrofóbicos (A, V, F, P, M, I, L e W), a cor azul para ácidos (D e E), a cor rosa para básicos (R e K) e a cor verde para os outros aminoácidos (S, T, Y, H, C, N, G e Q). 


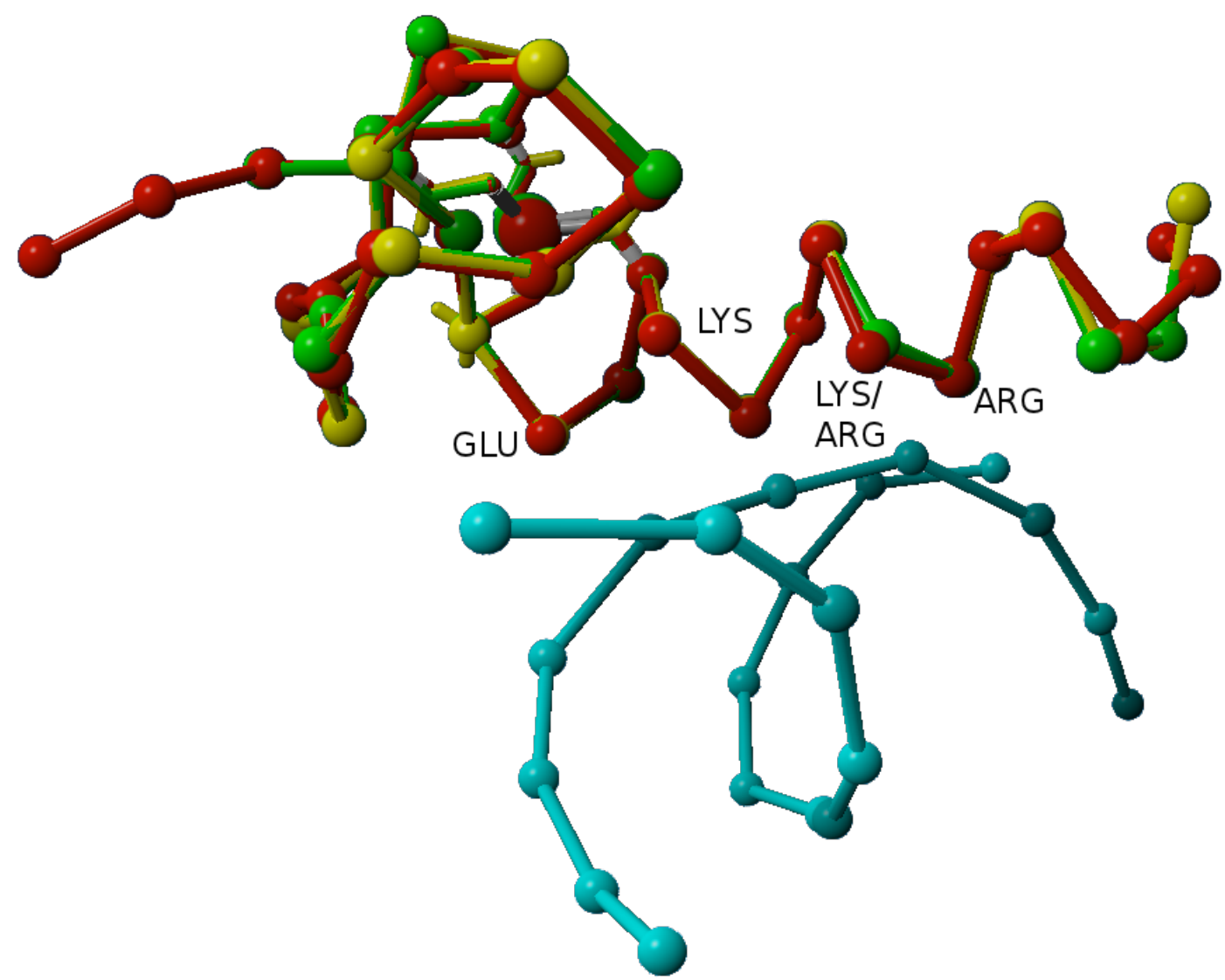

Figura 4.8: Alinhamento das estruturas tridimensionais dos DBDs dos três NRs modelos deste trabalho: RXR em verde, RAR- $\beta$ em amarelo e ER- $\alpha$ em vermelho. Os íons de Zn $2+$ estão representados em rosa, e a estrutura em azul claro é uma fita de DNA, representando o DNA compelxado aos NRs. 
4.3. Comparação de TFBSs obtidos pelo TFBSAnalyzer com TFBSs obtidos de resultados experimentais gerados in vivo

\subsection{Comparação de TFBSs obtidos pelo TFBSAnalyzer com}

\section{TFBSs obtidos de resultados experimentais gerados in} vivo

Após o cálculo das distribuições de energia de ligação, as previsões do TFBSAnalyzer foram comparadas com resultados experimentais, tanto para verificar a acurácia do método quanto para definir valores de corte de escore de ligação para os NRs modelos. Foram utilizados dois trabalhos experimentais, um para analisar o desempenho da predição para um heterodímero RAR- $\beta$-RXR e outro para um homodímero ER- $\alpha$. O primeiro, realizado por Ruiz e colaboradores (Ruiz et al., 1991), utiliza um experimento de linker scanning mutagenesis para verificar como a expressão gênica é afetada por mutações em um elemento responsivo a ácido retinoico. Já o segundo avalia a complexação do ER- $\alpha$ com a sequência consenso (AGGTCA) e todas as outras 18 sequências obtidas pela mutação de apenas uma base por vez. As seções a seguir apresentam os resultados obtidos com as comparações.

\subsubsection{Comparação com resultados experimentais: RAR- $\beta$ - RXR}

Como foi explicado na seção 3.5.1, foram utilizados os resultados experimentais obtidos em (Ruiz et al., 1991). No trabalho citado, o elemento responsivo a ácido retinoico $\operatorname{RARE} \beta$ teve sua sequência mutada, gerando nove sequências mutantes (m1 a m9). Estas sequências foram utilizadas como promotores do gene codificador da luciferase, proteína utilizada como repórter. Foi possível analisar a indução de atividade da luciferase, decorrente do reconhecimento das sequências mutadas pelo heterodímero RAR- $\beta$-RXR. Os resultados obtidos no trabalho de Ruiz estão na Figura 4.9. As sequências selvagem e $\mathrm{m} 1 \mathrm{a} \mathrm{m} 9$ foram varridas com o heterodímero em questão, utilizando o espaçador DR5 por ser o mais comum para o promotor RAR $\beta 2$ (Chanbom, 1992), e os resultados seguem nas Figuras 4.10 (selvagem) e 4.11 (mutações).

Como observa-se na Figura 4.10, foi encontrado um TFBS, com escore de 0,99. Ao mesmo tempo houve indução de atividade do gene repórter para essa sequência, portanto o resultado encontrado está coerente com o experimento de Ruiz. A sequência encontrada nesta posição consiste nas héxades GGGTTC e AAGTTC, separadas pelo espaçador ACCGA. Nossa hipótese é a de que mutações nesta sequncia que diminuíram a expressão observada por Ruiz et al levarão a um escore menor, além de não aumentar os escores nas regiões adjacentes. A Figura 4.11 apresenta os resultados obtidos com a varredura das sequências mutantes. 
4.3. Comparação de TFBSs obtidos pelo TFBSAnalyzer com TFBSs obtidos de resultados experimentais gerados in vivo

A

wt CGGGTAGGGTTCACCGAAAGTTCACTCGCATATA

m1 CTTTTAGGGTTCACCGAAAGTTCACTCGCA

m2 CGGGECTGGTTCACCGAAAGTTCACTCGCA

m3 CGGGTAGNATCACCGAAAGTTCACTCGCA

m4 CGGGTAGGGTCTPCCGAAAGTTCACTCGCA

m5 CGGGTAGGGTTCATATAAAGTTCACTCGCA

m6 CGGGTAGGGTTCACCGCECGTTCACTCGCA

m7 CGGGTAGGGTTCACCGAAATCACACTCGCA

m8 CGGGTAGGGTTCACCGAAAGTTACTTCGCA

m9 CGGGTAGGGTTCACCGAAAGTTCACGATCA

B

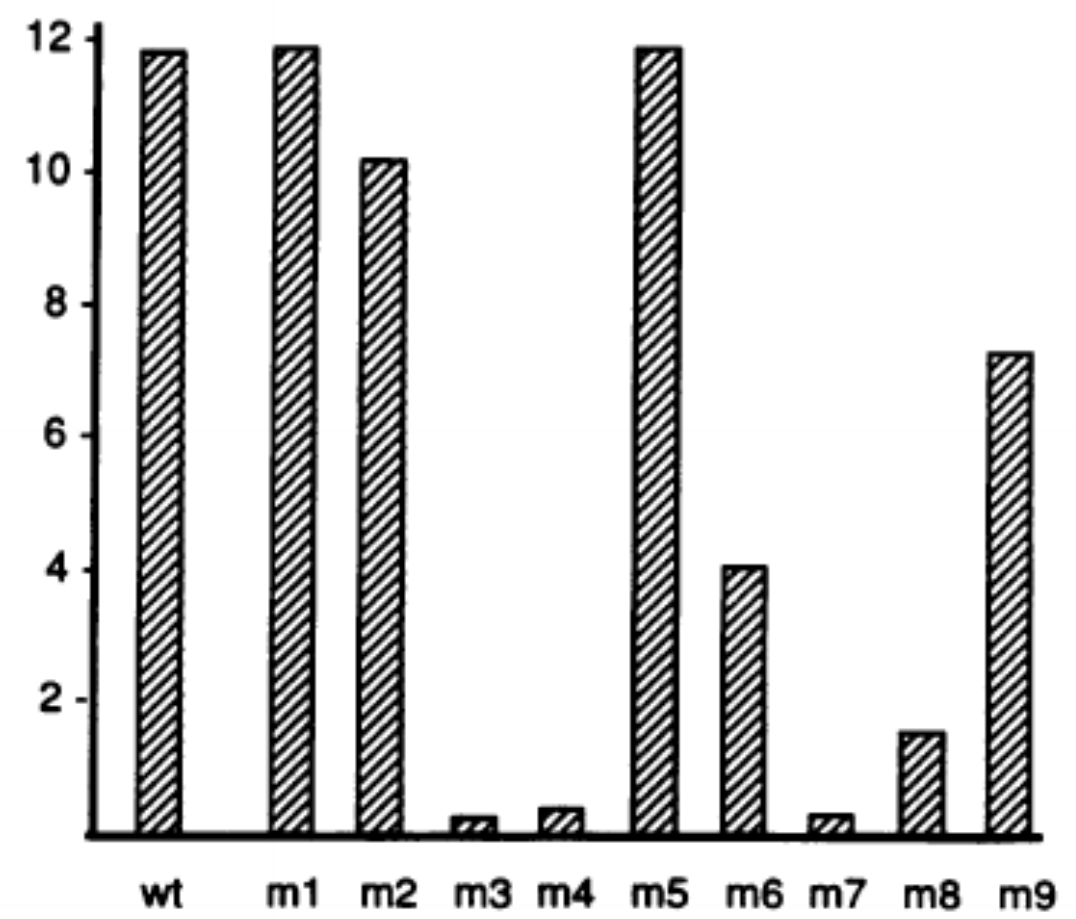

Figura 4.9: Linker scanning mutagenesis do $\operatorname{RARE} \beta$ contido no promotor do gene $\operatorname{RAR} \beta 2$. À direita temos a sequência do elemento responsivo selvagem (wt) e dos mutantes (m1 - m9). As trincas de nucleotídeos mutados estão demarcadas em negrito, e as sequências sublinhadas são os TFBSs sugeridos por Ruiz e colaboradores. À esquerda temos a indução da atividade do promotor por co-transfecção de RAR- $\beta$. Imagem extraída de (Ruiz et al. 1991). 


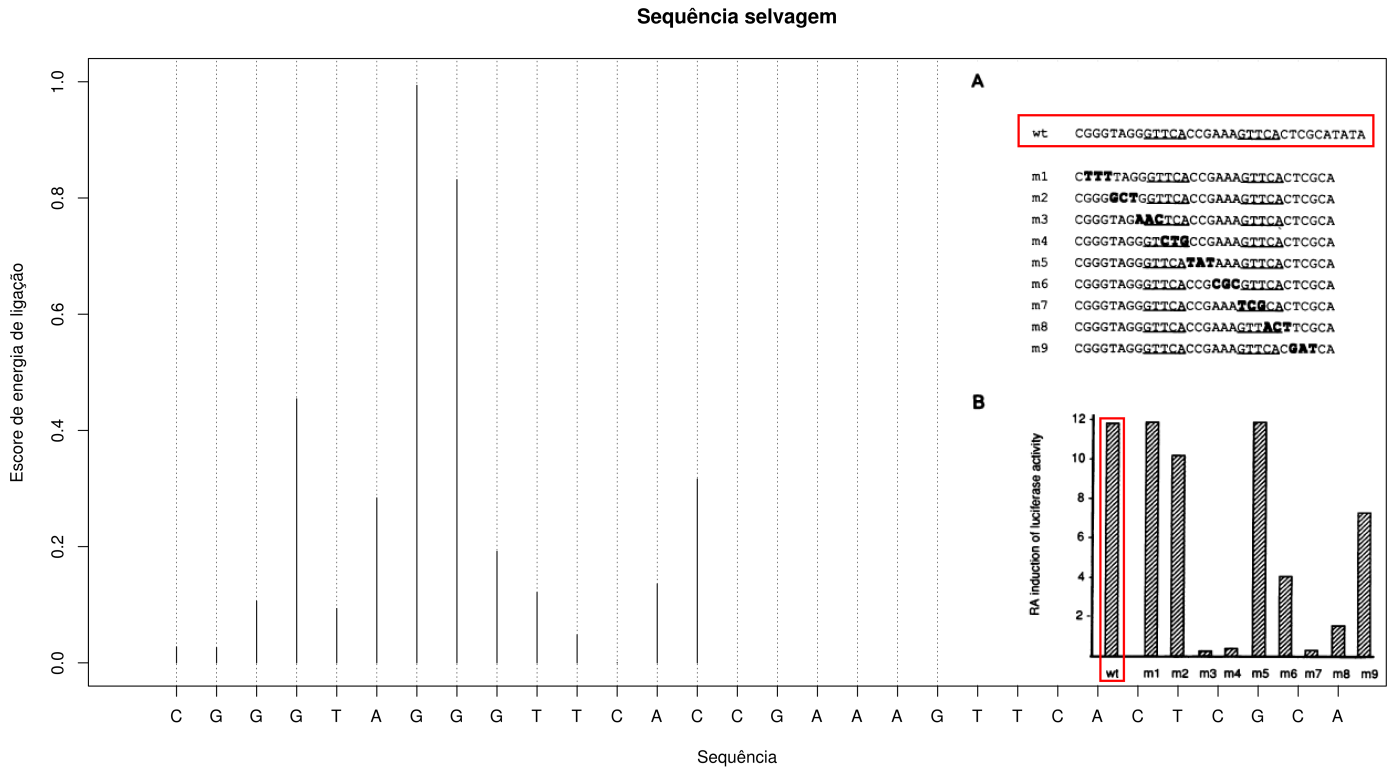

Figura 4.10: Varredura do RARE $\beta$ com um dímero dos DBDs de RAR- $\beta$ e RXR, com espaçador DR5. As caixas vermelhas indicam a sequência em análise e o nível de atividade obtido para a mesma. O valor associado a cada base representa o escore calculado para a sequência completa (primeira héxade reconhecida, espaçador e segunda héxade reconhecida) iniciando desta base. Por exemplo, iniciando a sequncia na sétima base obtivemos um escore de aproximadamente 1, sendo a primeira héxade a sequência GGGTTC, o espaçador ACCGA e a segunda héxade AAGTTC. 


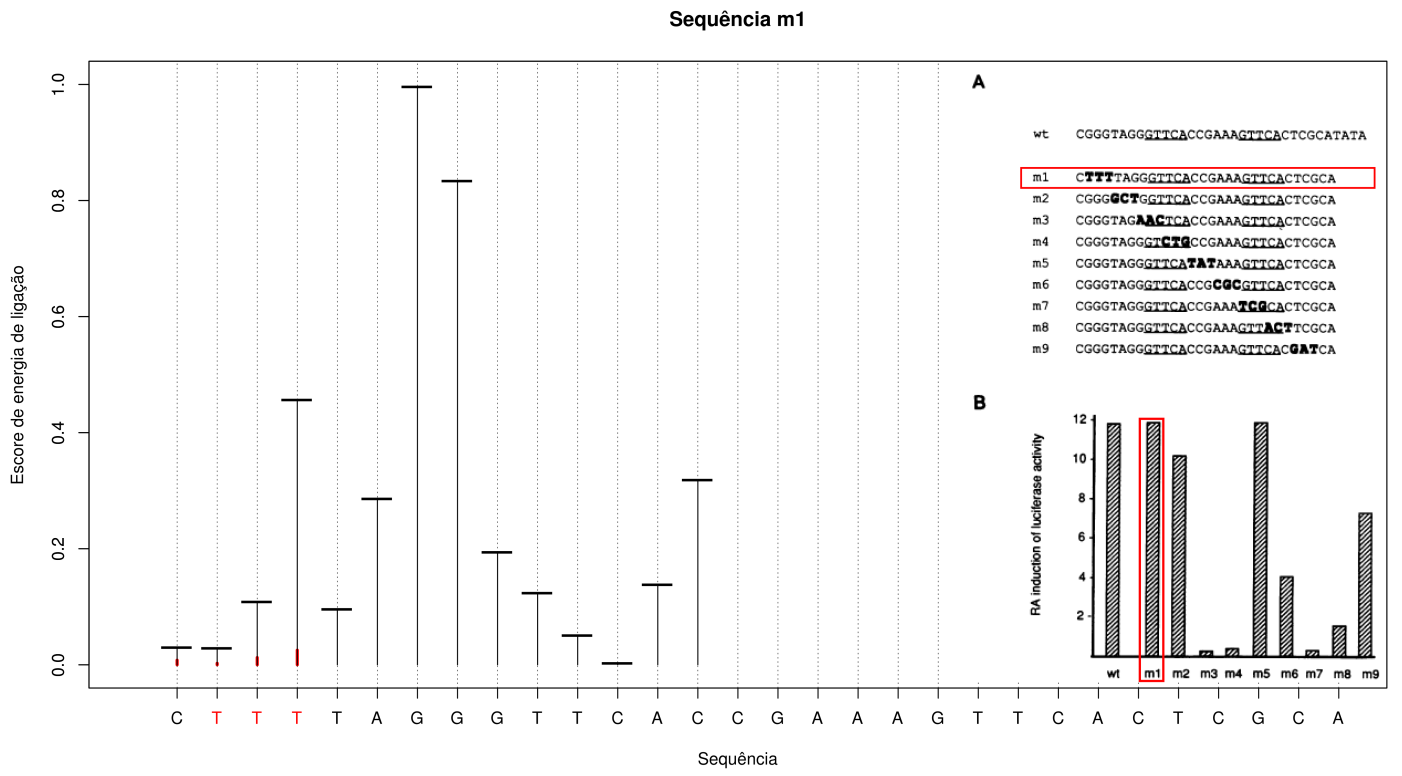

(a) Sequência m1: mutações localizadas a 5' da primeira héxade. Sequência principal (sem espaçador): GGGTTC - AAGTTC

Figura 4.11: Varredura das sequências mutantes de RARE- $\beta$ com um dímero dos DBDs de RAR- $\beta$ e RXR e espaçador DR5. As figuras (a) a (i) correspondem às sequências $\mathrm{m} 1 \mathrm{a} \mathrm{m} 9$, respectivamente. Á direita de cada figura está apresentado o resultado experimental de Ruiz, no qual as caixas vermelhas indicam a sequência em análise e o nível de atividade obtido para a mesma. Já o gráfico da varredura apresenta o resultado obtido para a sequência selvagem, destacando em vermelho as alterações para a sequência mutante em questão. As bases em vermelho no eixo das abcissas mostram as mutações feitas na sequência em análise. 


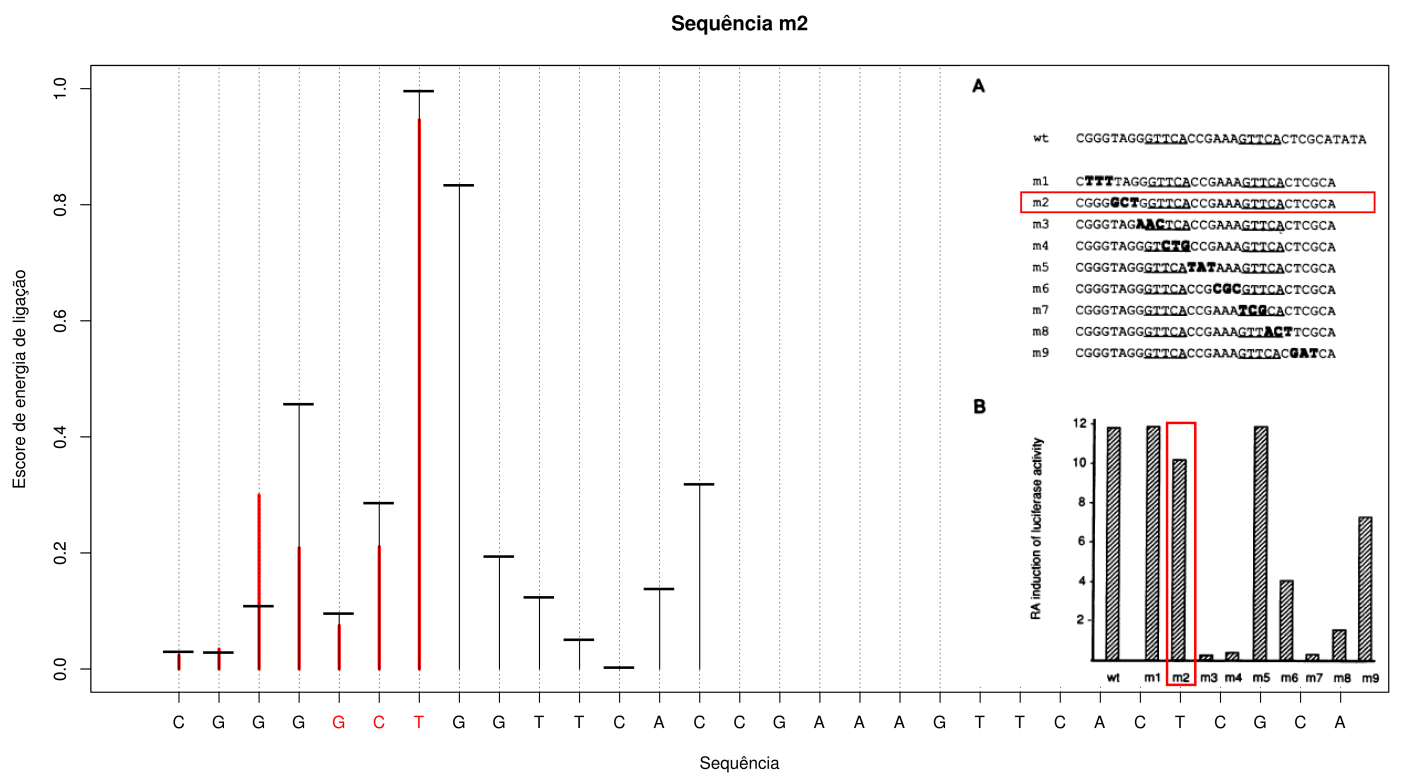

(b) Sequência m2: mutações localizadas a 5' da primeira héxade e na primeira base da primeira héxade. Sequência principal (sem espaçador): TGGTTC - AAGTTC

Sequência m3

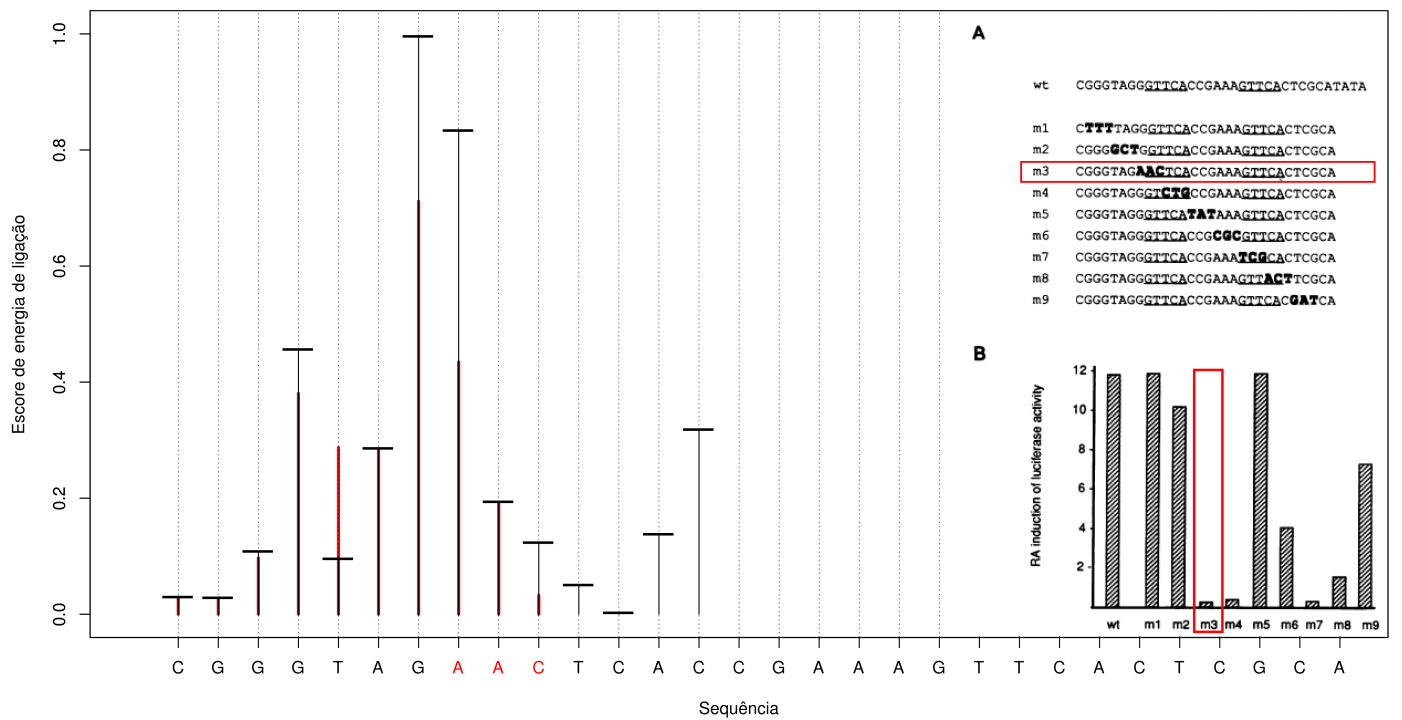

(c) Sequência m3: mutações localizadas na primeira héxade. Sequência principal (sem espaçador): GAACTC - AAGTTC 


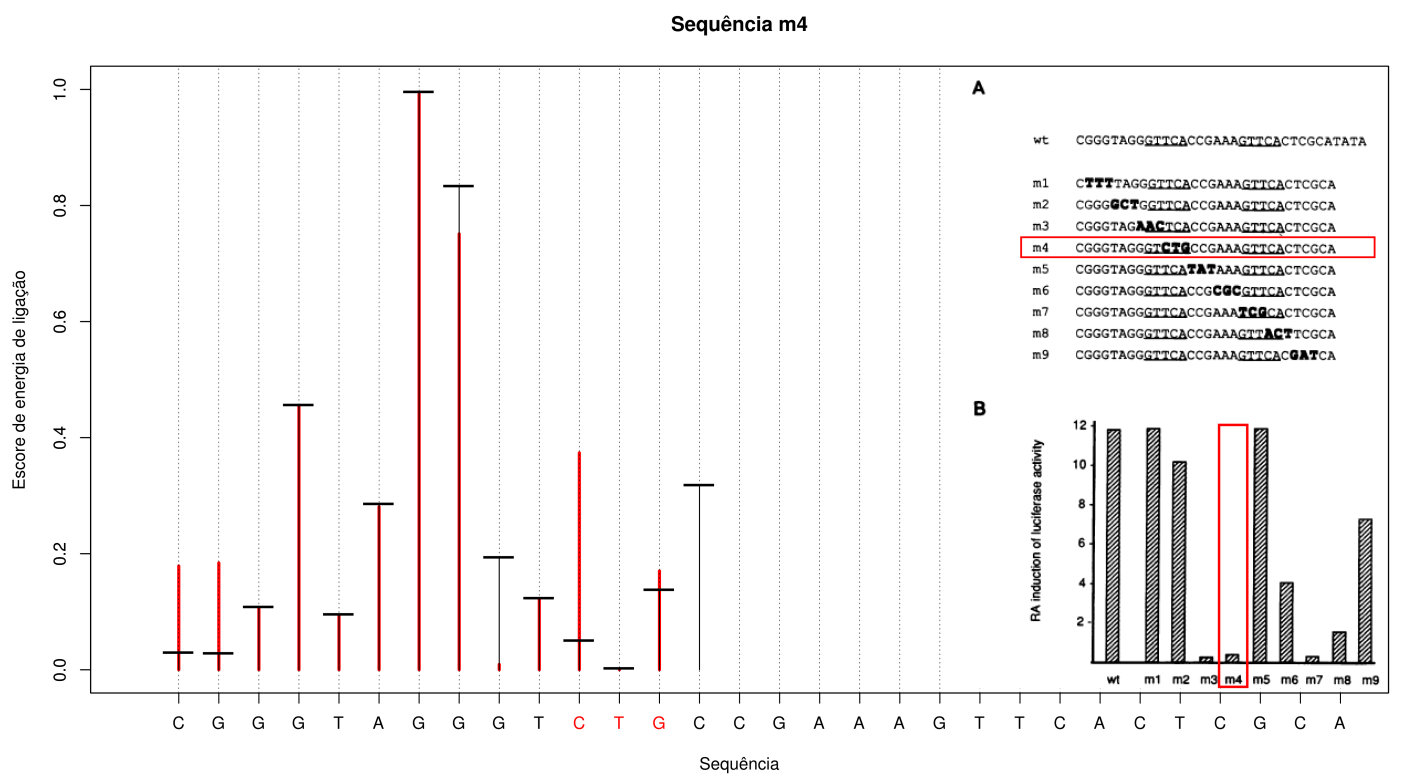

(d) Sequência m4: mutações localizadas na primeira héxade. Sequência principal (sem espaçador): GGGTCT - AAGTTC

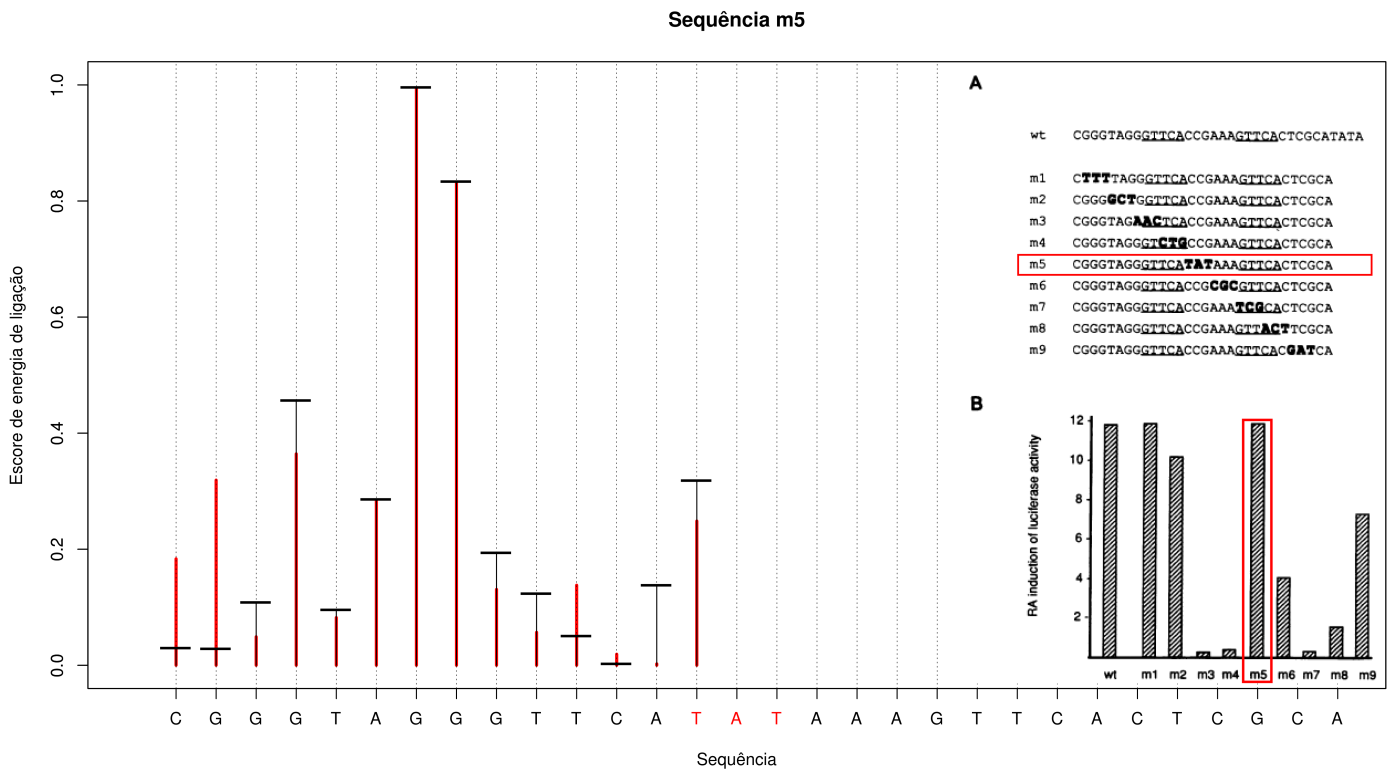

(e) Sequência m5: mutações localizadas no espaçador. Sequência principal (sem espaçador): GGGTTC AAGTTC 


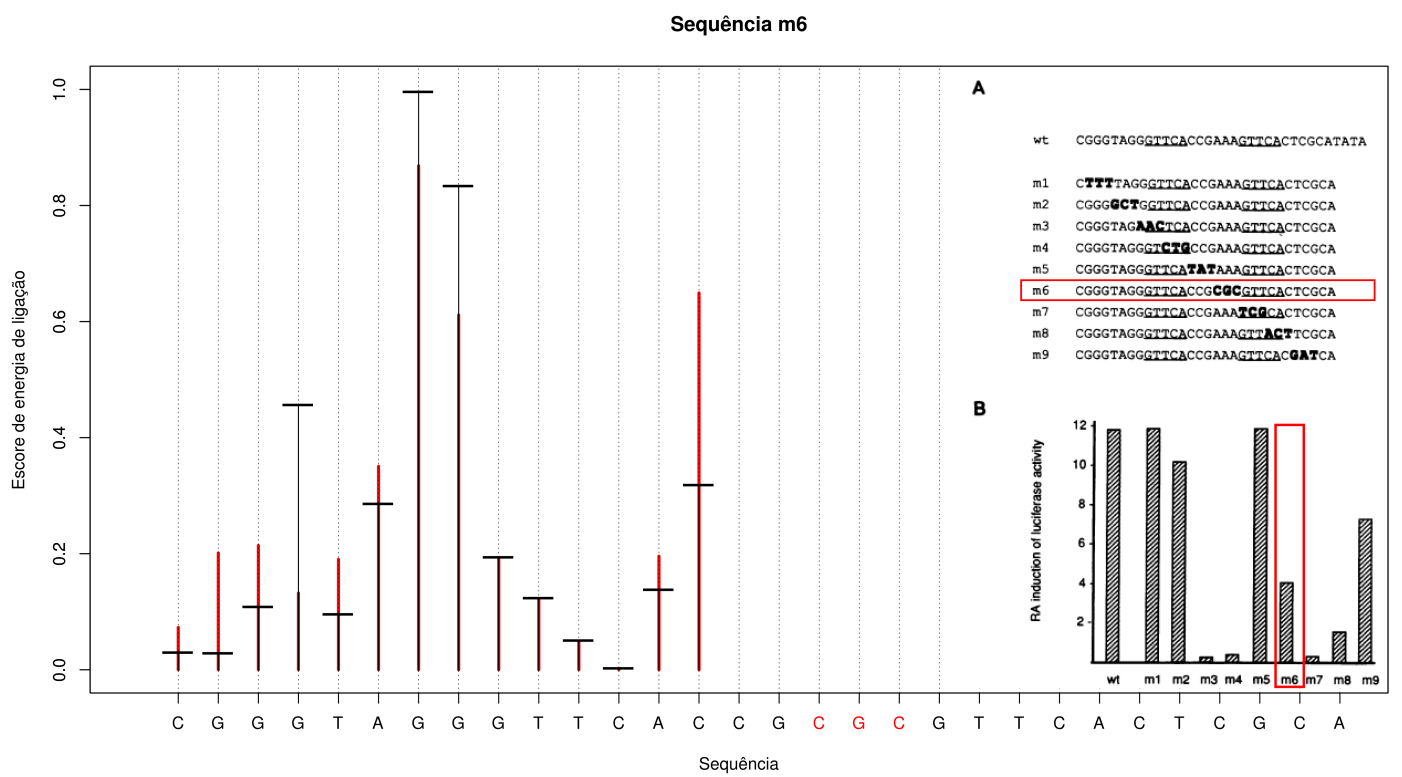

(f) Sequência m6: mutações localizadas na segunda héxade. Sequência principal (sem espaçador): GGGTTC - GCGTTC

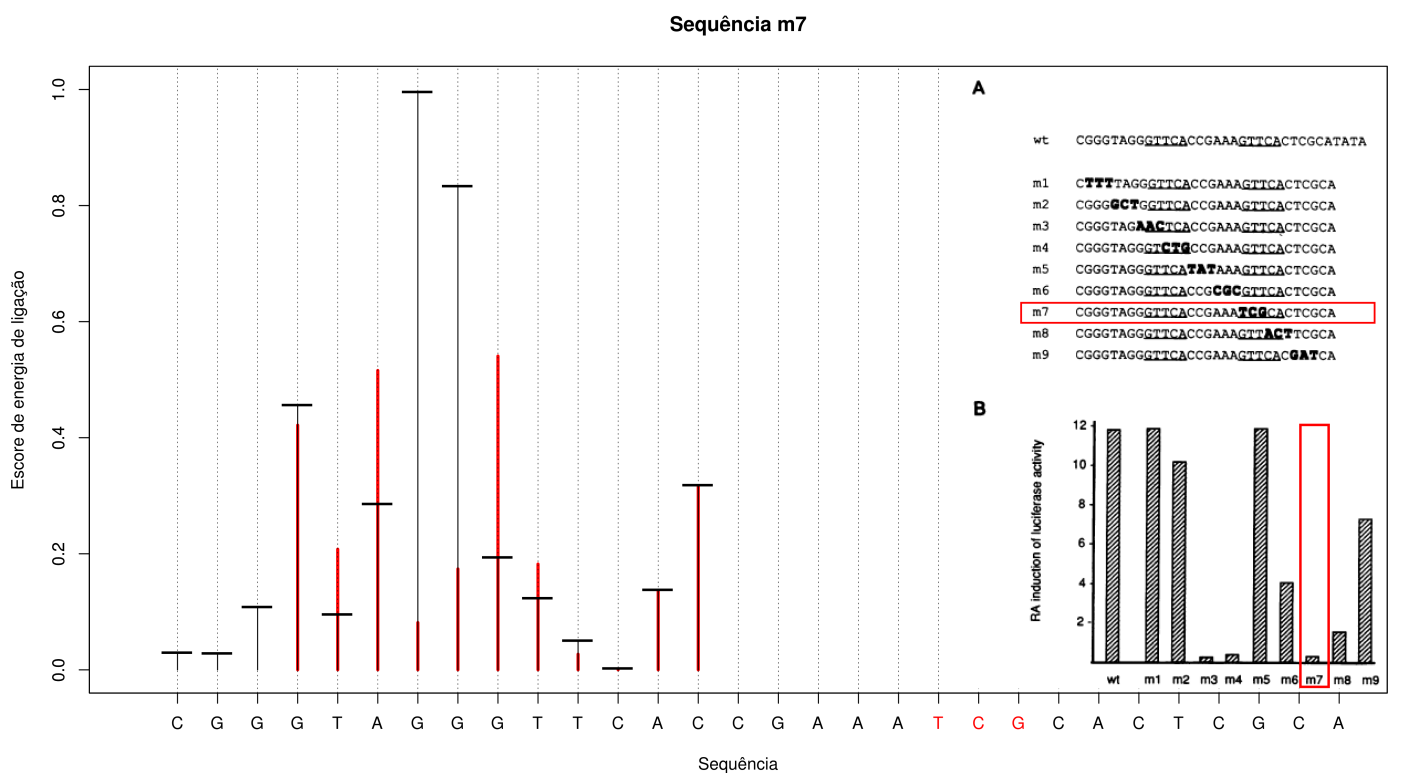

(g) Sequência m7: mutações localizadas na segunda héxade. Sequência principal (sem espaçador): GGGTTC - AATCGC 


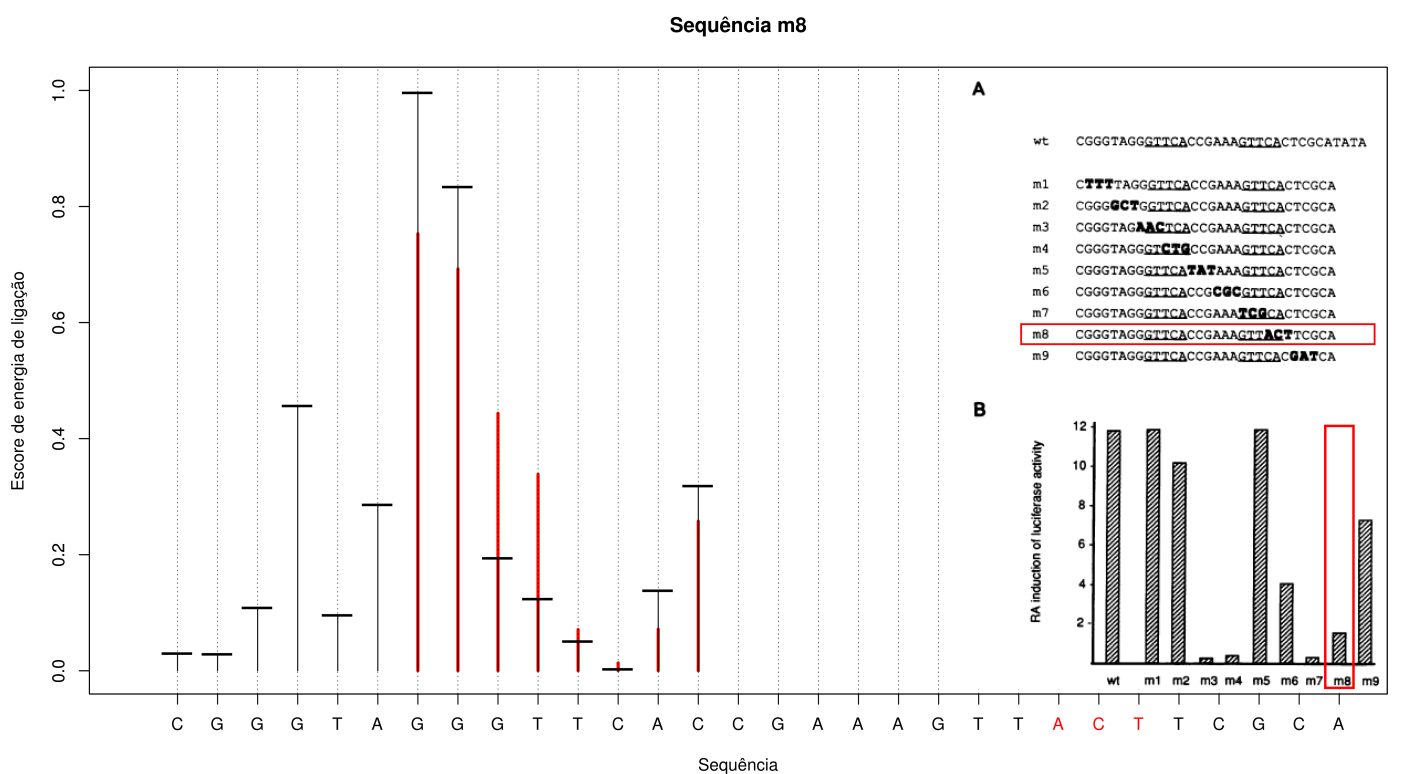

(h) Sequência m8: mutações localizadas na segunda héxade. Sequência principal (sem espaçador): GGGTTC - AAGTTA

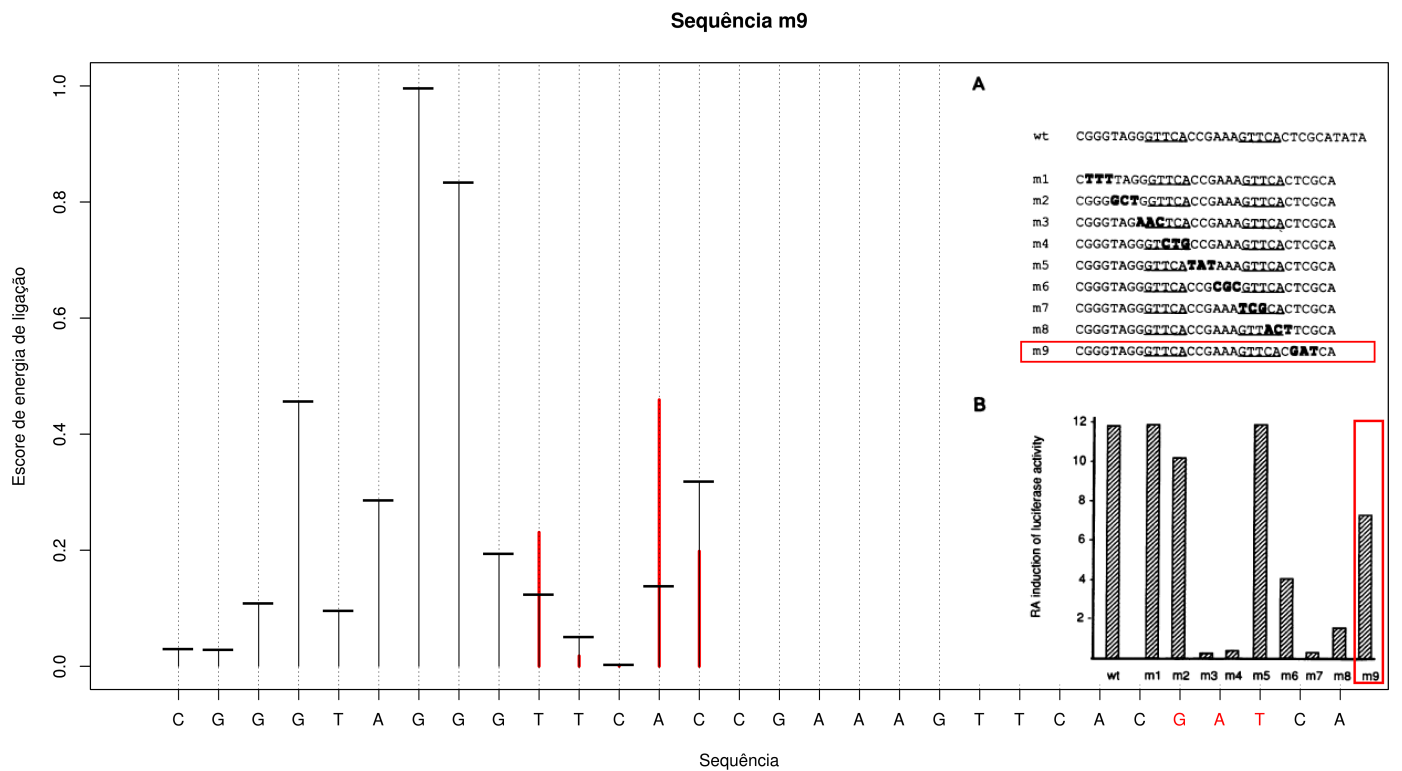

(i) Sequência m9: mutações localizadas a 3' da segunda héxade. Sequência principal (sem espaçador): GGGTTC - AAGTTC 
Tabela 4.3: Comparação entre os resultados de Ruiz e as varreduras realizadas com um dímero de RAR- $\beta$ e RXR. Na linha "Ruiz", estão apresentados os valores de atividade aproximados, obtidos por Ruiz et al. Na linha "Maior escore" está anotado o maior valor de escore obtido na varredura da respectiva sequência.

\begin{tabular}{|c|c|c|c|c|c|c|c|c|c|c|}
\cline { 2 - 12 } \multicolumn{1}{c|}{} & \multicolumn{10}{c|}{ Sequência analisada } \\
\cline { 2 - 12 } \multicolumn{1}{c|}{} & $\mathrm{wt}$ & $\mathrm{m} 1$ & $\mathrm{~m} 2$ & $\mathrm{~m} 3$ & $\mathrm{~m} 4$ & $\mathrm{~m} 5$ & $\mathrm{~m} 6$ & $\mathrm{~m} 7$ & $\mathrm{~m} 8$ & $\mathrm{~m} 9$ \\
\hline Ruiz & 12 & 12 & 10 & 0 & 0 & 12 & 4 & 0 & 2 & 8 \\
\hline Maior escore & 0,99 & 0,99 & 0,94 & 0,71 & 0,99 & 0,99 & 0,87 & 0,54 & 0,75 & 0,99 \\
\hline
\end{tabular}

De acordo com os resultados de Ruiz, as sequências mutantes $\mathrm{m} 1, \mathrm{~m} 2, \mathrm{~m} 5, \mathrm{~m} 6$ e m9 não foram capazer de silenciar a expressão gênica (atividade abaixo de 2). As varreduras destas sequências apresentam um pico de escore, portanto são todas resultados positivos verdadeiros. Especificamente no caso das sequências $\mathrm{m} 1, \mathrm{~m} 5$ e m9, as mutações ocorrem fora das héxades reconhecidas na sequência principal, portanto não deveriam mesmo afetar o escore calculado, já que este é independente das bases vizinhas ao sítio.

As outras sequências mutantes (m3, m4, m7 e m8) afetaram drasticamente a expressão gênica no experimento de Ruiz, reduzindo a atividade a valores menores do que 2. A interpretação deste resultado depende portanto do valor de corte escolhido. Mais adiante está uma análise para estabelecer os valores de corte mais adequados para este heterodímero. Já para a sequência $\mathrm{m} 4$ obtivemos um resultado falso-positivo. É possível que neste caso a diminuição de entropia do sistema seja desfavorável à complexação. A varredura da sequência $m 7$ não apresentou nenhum pico de escore de ligação, portanto é um resultado negativo verdadeiro. Finalmente, para as sequências $\mathrm{m} 3$ e m8 foram encontrados picos de escore de ligação, porém de valores mais baixos do que o pico nos casos positivos verdadeiros. Portanto, a interpretação destes resultados depende do valor de corte adotado. Para um valor de corte muito baixo (ou seja, pouco estringente), estes resultados seriam falso-positivos, enquanto para valores mais altos seriam negativos verdadeiros. É necessário, portanto, definir um valor de corte de pontuação para realizar a busca por TFBSs em outras sequências. Com o intuito de encontrar um valor adequado de corte, os resultados das varreduras acima foram sumarizados na Tabela 4.3. Para cada sequência utilizada no experimento de transativação feito por Ruiz, a tabela mostra os valores de atividade aproximados para cada sequência e o maior escore obtido na varredura.

A partir desses dados foi possível traçar o gráfico da Figura 4.13, que mostra a porcentagem de acertos (TFBSs encontrados ou sequências comuns descartadas), falsopositivos (sequências comuns classificadas como TFBSs) e falso-negativos (TFBSs classificados como sequências comuns) para valores de corte variando entre 0 e 1 , com passo de 0.01. Também foi construída a curva ROC (Receiver operating characteristic) para todos estes valores de corte (Figura 4.14). A curva ROC relaciona a taxa de positivos verdadeiros (sensibilidade) com a taxa de falso-positivos de uma amostra (especificidade). A Tabela 4.4 mostra como são obtidas as porcentagens do gráfico e as 
taxas de uma curva ROC.

Tabela 4.4: Explanação sobre as porcentagens e taxas utilizadas como parâmetros para avaliar a acurácia do TFBSAnalyzer.

Para um experimento de amostragem, podemos definir as seguintes variáveis:

\begin{tabular}{|c|c|c|c|}
\cline { 3 - 4 } \multicolumn{2}{c|}{} & \multicolumn{2}{c|}{ Valor Real } \\
\cline { 3 - 4 } \multicolumn{2}{c|}{ Predições } & Positivos (P) & Negativos (N) \\
\cline { 2 - 4 } & Negativos (P') & Positivos reais (pr) & Falso-positivos (fp) \\
\hline
\end{tabular}

Temos então que $P=p r+f p, N=f n+n r, P^{\prime}=p r+f n e N^{\prime}=f p+n r$. A porcentagem de acertos foi definida como $(p r+n r) /(P+N)$, a porcentagem de

falso-positivos como $\mathrm{fp} /(P+N)$ e a porcentagem de falso-negativos como $f n /(P+N)$. A curva ROC relaciona a taxa de positivos reais (sensibilidade), definida por $\mathrm{pr} / P$, com a taxa de falso-positivos (especificidade), definida por $f p / N$. Traça-se a reta $\mathrm{y}=\mathrm{x}$ na curva $\mathrm{ROC}$ para representar um classificador aleatório, ou seja, uma amostra será classificada como positiva com $50 \%$ de probabilidade. Portanto, classificadores mais acurados do que o aleatório aparecem como pontos acima da reta $y=x$, e quanto mais distantes desta reta, mais acurados eles serão.

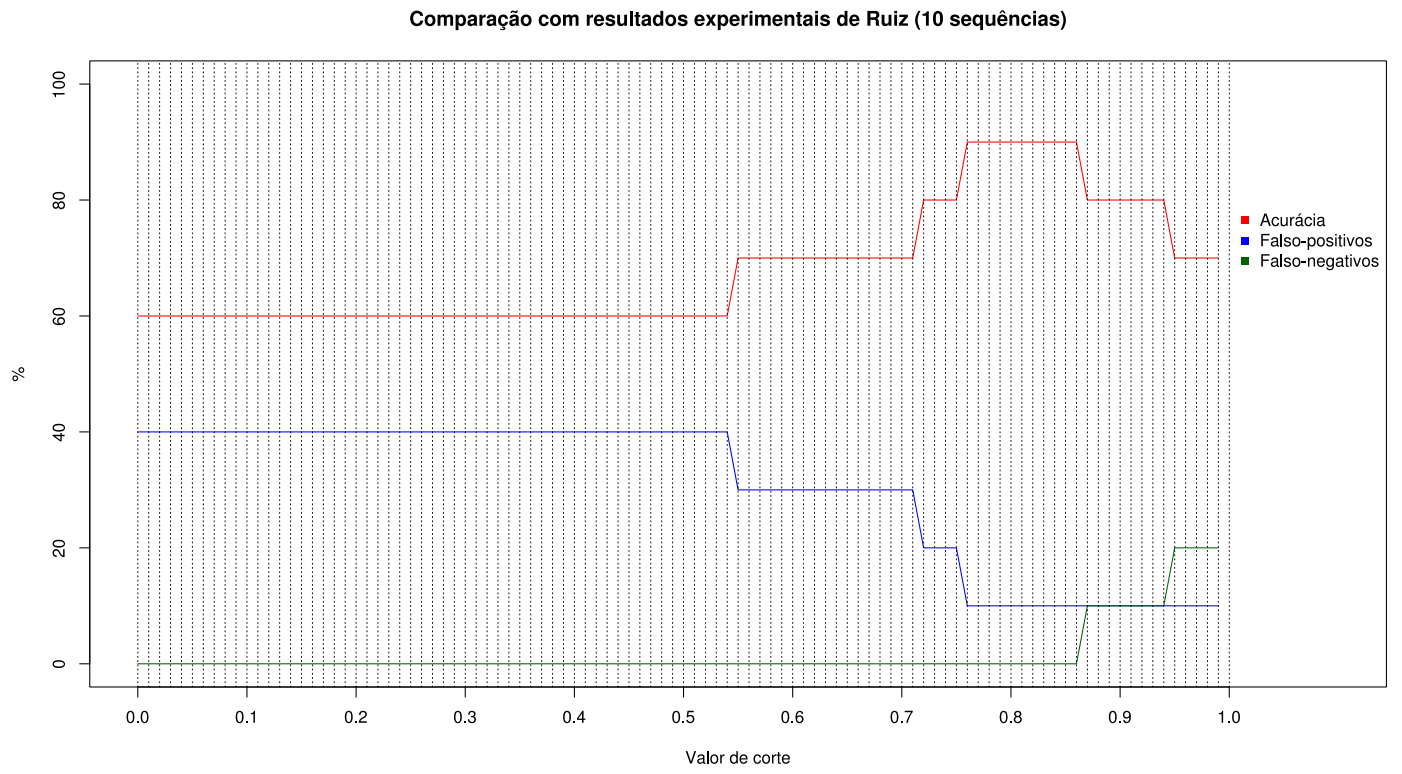

Figura 4.13: Comparação dos resultados experimentais de Ruiz com os resultados de varredura com um dímero dos DBDs de RAR- $\beta$ e RXR, para vários valores de corte.

Como esperado, observamos uma diminuição no número de falso-positivos com o aumento do valor de corte, em conjunto com um aumento do número de falso- 


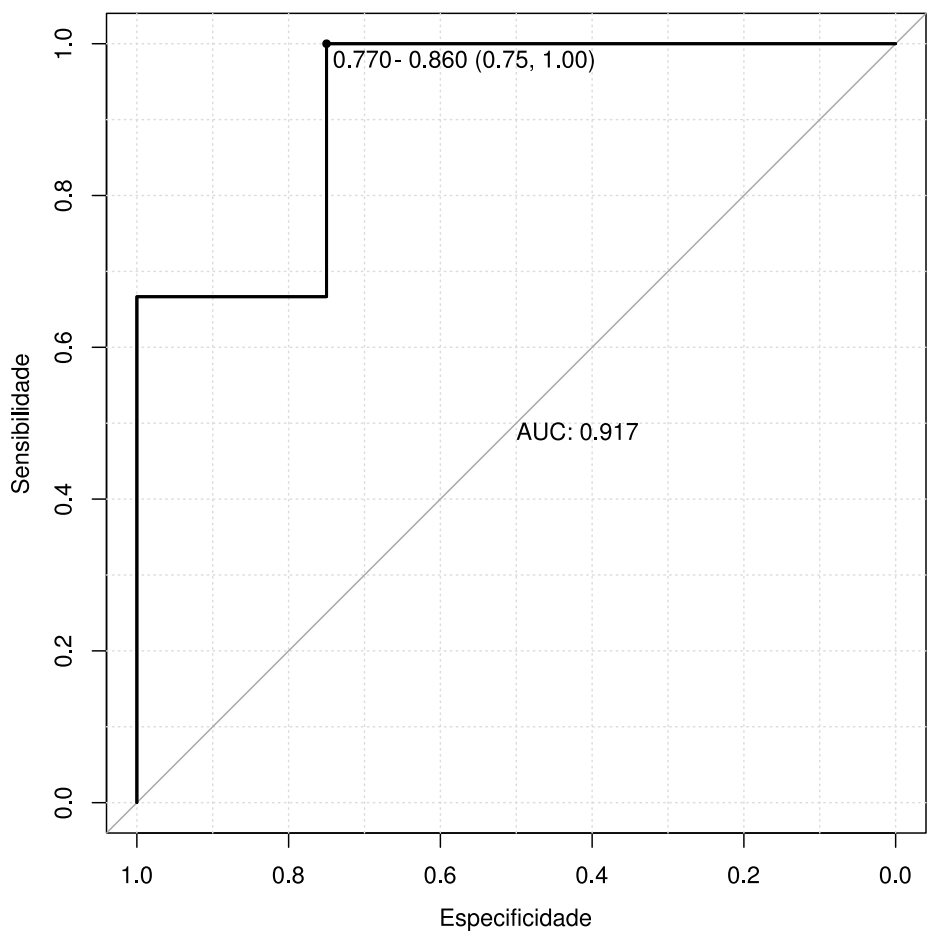

Figura 4.14: Curva ROC comparando os vários valores de corte testados com os resultados experimentais de Ruiz. O intervalo apresentado no melhor ponto consiste nos valores de corte que resultam neste ponto, bem como suas coordenadas (especificidade, sensibilidade). O valor AUC corresponde à área sob a curva (Area Under the Curve), que define a probabilidade de o método classificar um resultado positivo com escore maior do que o de um resultado negativo.

negativos (Figura 4.13). O intervalo de valor de corte em que foi obtido a maior porcentagem de acertos foi entre 0,77 e 0,86 , com $90 \%$ de acertos e $10 \%$ de falso-positivos. Na curva ROC (Figura 4.14), este mesmo intervalo atingiu o melhor desempenho (mais distante da reta $\mathrm{y}=\mathrm{x}$ ). Logo a melhor faixa para realizar buscas por TFBSs no caso do RAR- $\beta$ seria de 0,77 a 0,86. Estes valores são, porém, apenas uma estimativa, que pode ser melhorada se mais comparações com outros dados experimentais forem realizadas. Também é possível que se deseje encontrar TFBSs que apresentem uma força de interação com o fator de transcrição mais fraca. No intervalo sugerido, esses sítios podem aparecer como falso-negativos. Um intervalo de valores de corte que permitiria encontrar estes sítios seria, por exemplo, de 0,6 a 0,7. Nessa situação, deve-se levar em conta que a taxa de falso-positivos aumentará bastante, tornando-se então uma questão de solução de compromisso. 


\subsubsection{Comparação com resultados experimentais: ER- $\alpha$}

Como foi explicado na seção 3.5.2, foram utilizados os resultados experimentais obtidos em (Nguyen et al., 2007) para validar o algoritmo proposto. No trabalho citado, o TFBS de 6 bps contido no promotor vitERE (Klinge, 2001) foi mutado de maneira combinatória, ou seja, cada nucleotídeo da sequência original foi substituído pelas outras três possibilidades, repetindo a mesma mutação para o TFBS do outro monômero. Foram geradas, portanto, 18 sequências mutantes. Estas sequências foram incubadas com ER- $\alpha$, e em seguida submetidas ao experimento de mobilidade eletroforética. Com o resultado deste experimento (Figura 4.15) é possível determinar se houve ou não complexação entre as sequências mutantes e o ER- $\alpha$. A sequência selvagem e as sequências mutantes foram varridas pelo nosso algoritmo usando como modelo um dímero de ER- $\alpha$, com espaçador IR3, o mesmo encontrado na estrutura deste dímero descrita no arquivo PDB 1HCQ. Os resultados seguem nas Figuras 4.16 e 4.17, que mostram os escores de ligação obtidos na varredura de cada sequência e identificam com um asterisco qual trilha do gel corresponde à sequência em análise.

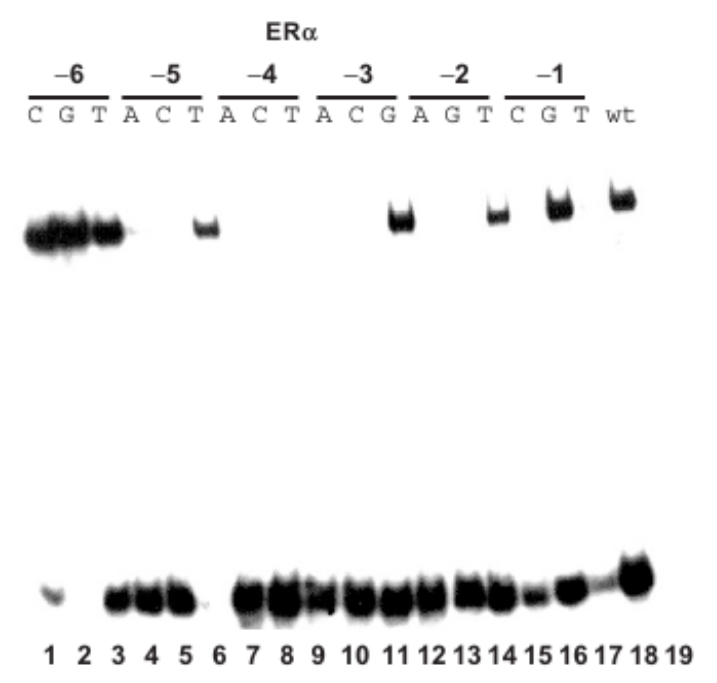

Figura 4.15: Efeito de mutações nas duas héxades do TFBS de ER- $\alpha$ na formação de complexos. Imagem extraída de (Nguyen et al. 2007)

A Figura 4.16 mostra que o sítio de ligação de ER- $\alpha$ contido no promotor vitERE foi encontrado pelo método proposto, com um escore de energia de ligação de aproximadamente 0.94. Ao mesmo tempo, houve complexação no experimento de mobilidade eletroforética, o que mostra a validade do mesmo. A Figura 4.17 apresenta os resultados das varreduras para todas as 18 sequêncis mutantes do experimento de Nguyen. 


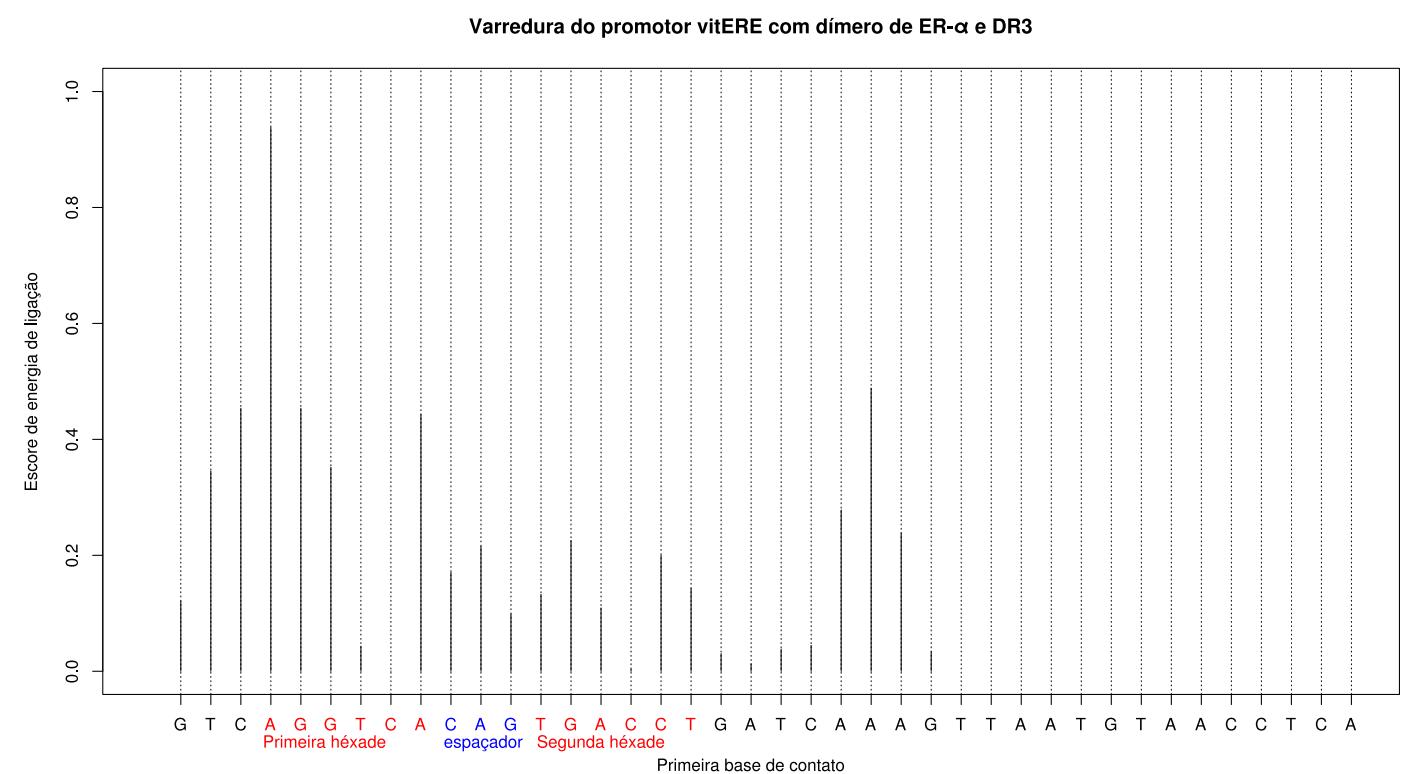

Figura 4.16: Varredura da sequência promotora vitERE com um dímero simétrico de ER- $\alpha$, com espaçador IR3. O valor associado a cada base representa o escore calculado para a sequência completa (primeira héxade reconhecida, espaçador e segunda héxade reconhecida) iniciando desta base. A segunda héxade deve ser entendida como o complementar reverso da sequência reconhecida pelo DBD de ER- $\alpha$. As héxades reconhecidas na sequência selvagem aparecem em vermelho e o espaçador em azul. 


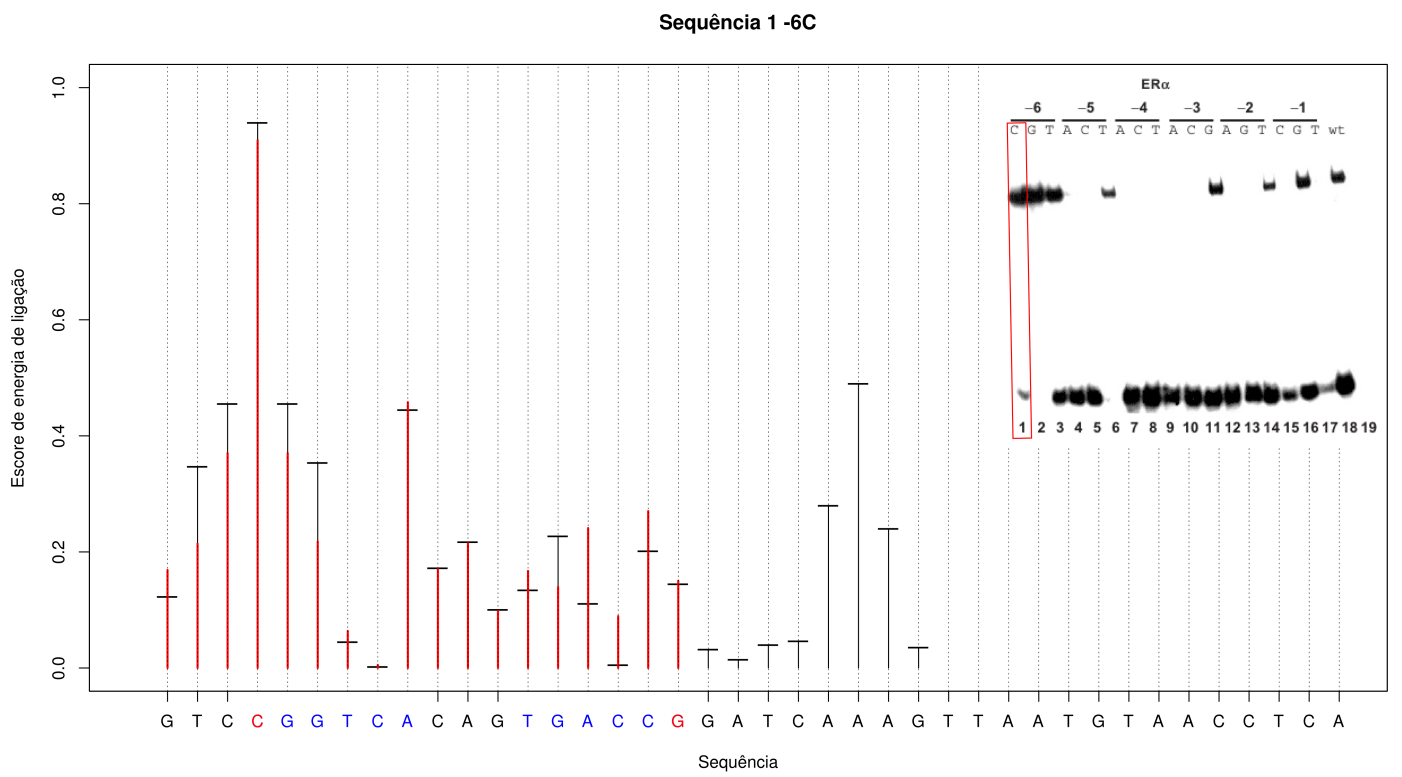

(a) Sequência 1: vitERE mutado nas posições -6C e +6G. A sequência reconhecida por ambas as héxades é CGGTCA.

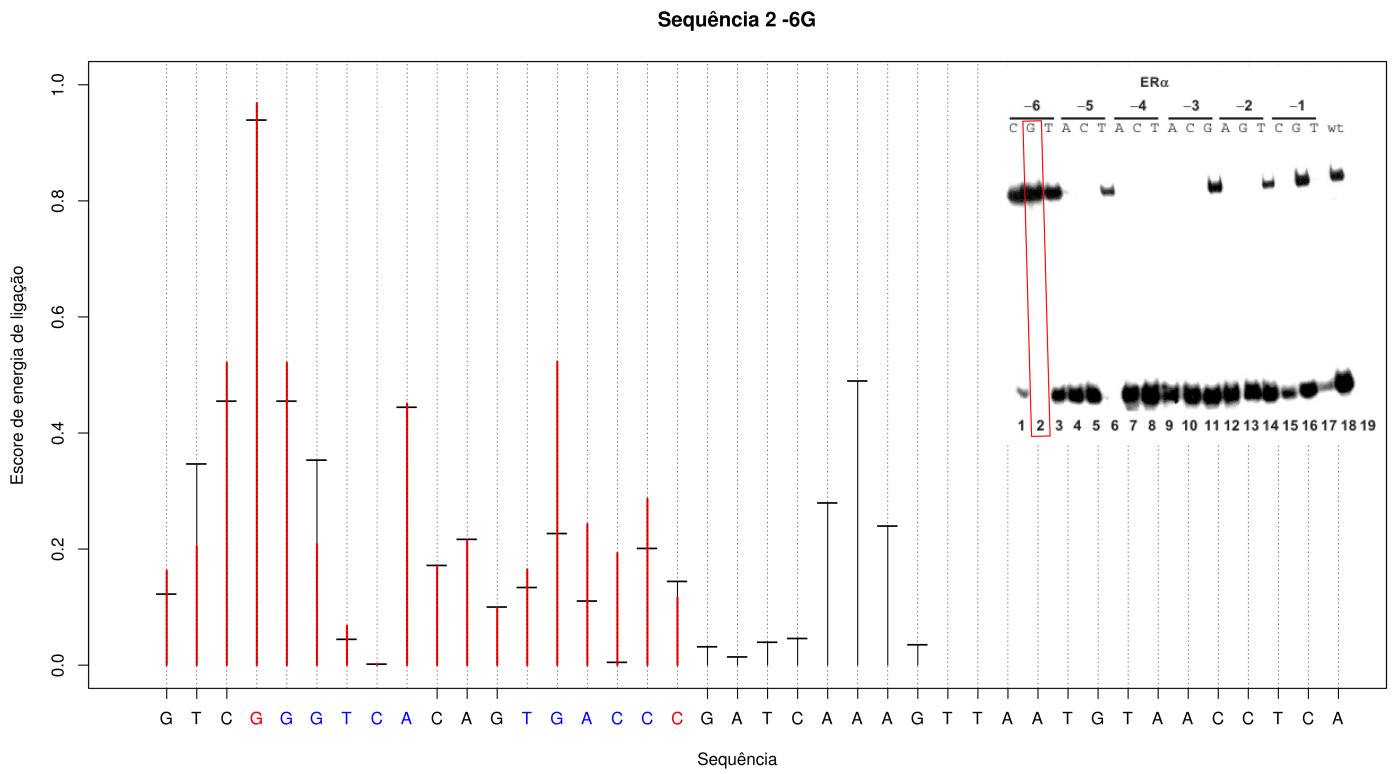

(b) Sequência 2: vitERE mutado nas posições $-6 \mathrm{G}$ e $+6 \mathrm{C}$. A sequência reconhecida por ambas as héxades é GGGTCA.

Figura 4.17: Varredura das sequências mutantes de vitERE com um dímero de ER- $\alpha$ e espaçador IR3. Cada figura representa uma mutação pontual na primeira héxade e outra equivalente na segunda, de modo que a sequência reconhecida por um monômero é idêntica à reconhecida pelo outro. À direita de cada figura está apresentado o resultado experimental de Nguyen, no qual as caixas vermelhas indicam a sequência em análise se houve ou não complexação com o TF. Já o gráfico da varredura apresenta o resultado obtido para a sequência selvagem, destacando em vermelho as alterações para a sequência mutante em questão. As bases em vermelho no eixo das abcissas mostram as mutações feitas na sequência em análise, e as bases em azul são as duas héxades reconhecidas na sequência selvagem. 


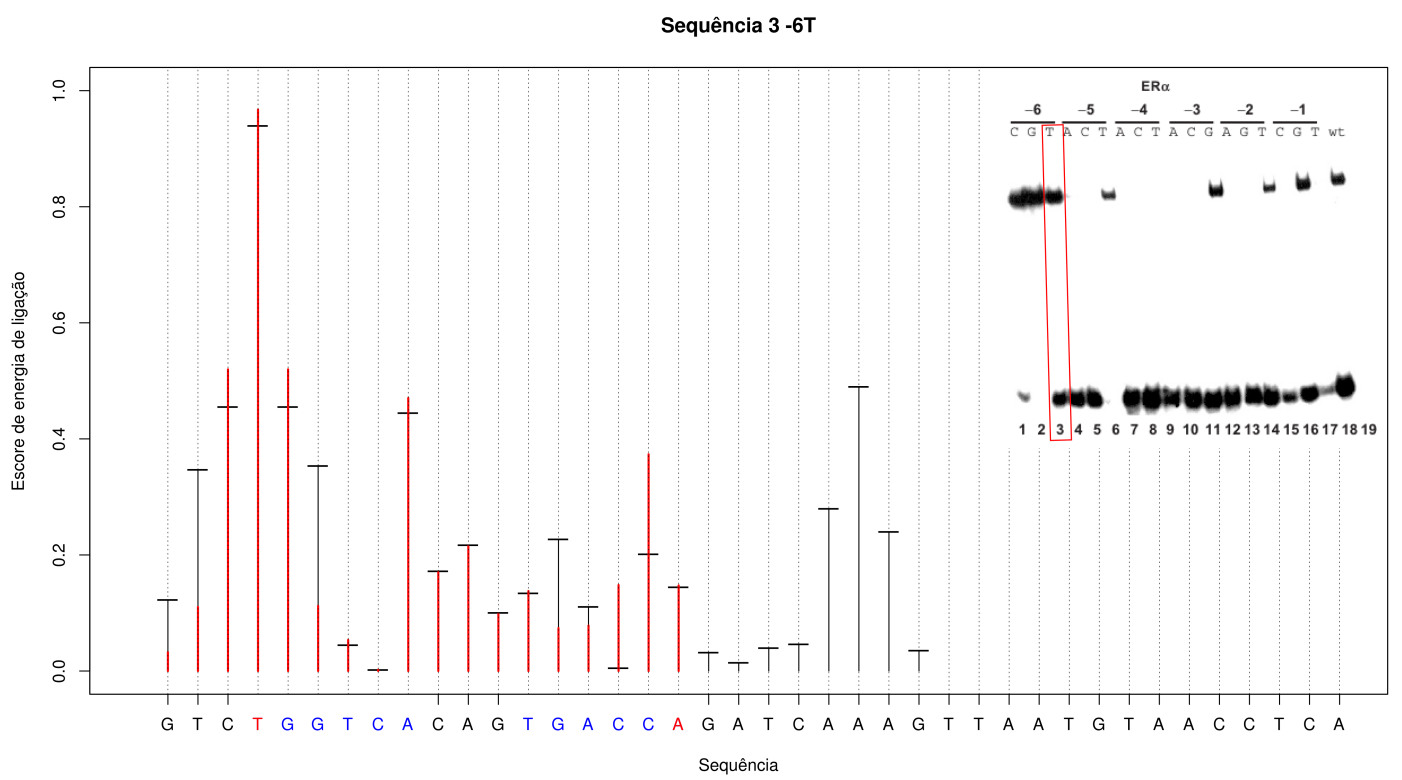

(c) Sequência 3: vitERE mutado nas posições -6T e +6A. A sequência reconhecida por ambas as héxades é TGGTCA.

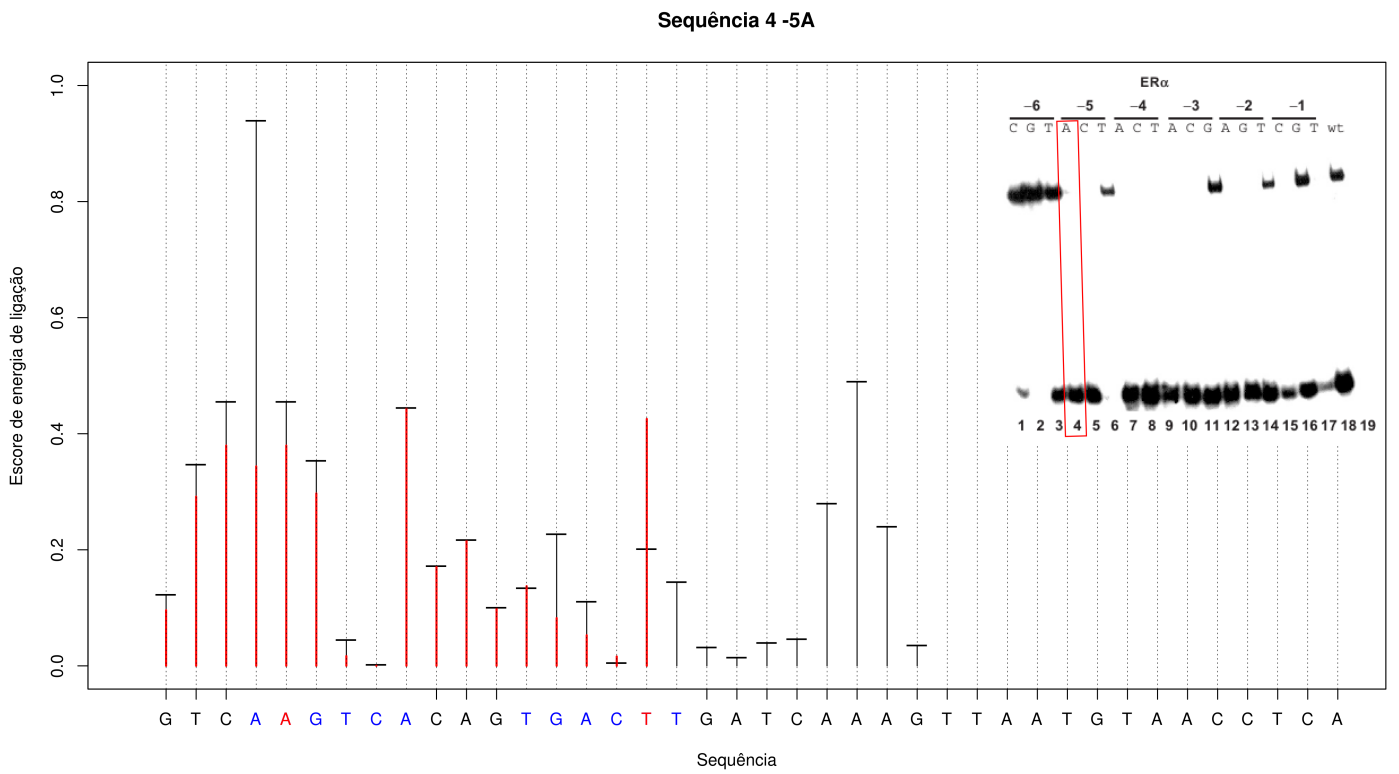

(d) Sequência 4: vitERE mutado nas posições -5A e +5T. A sequência reconhecida por ambas as héxades é AAGTCA. 


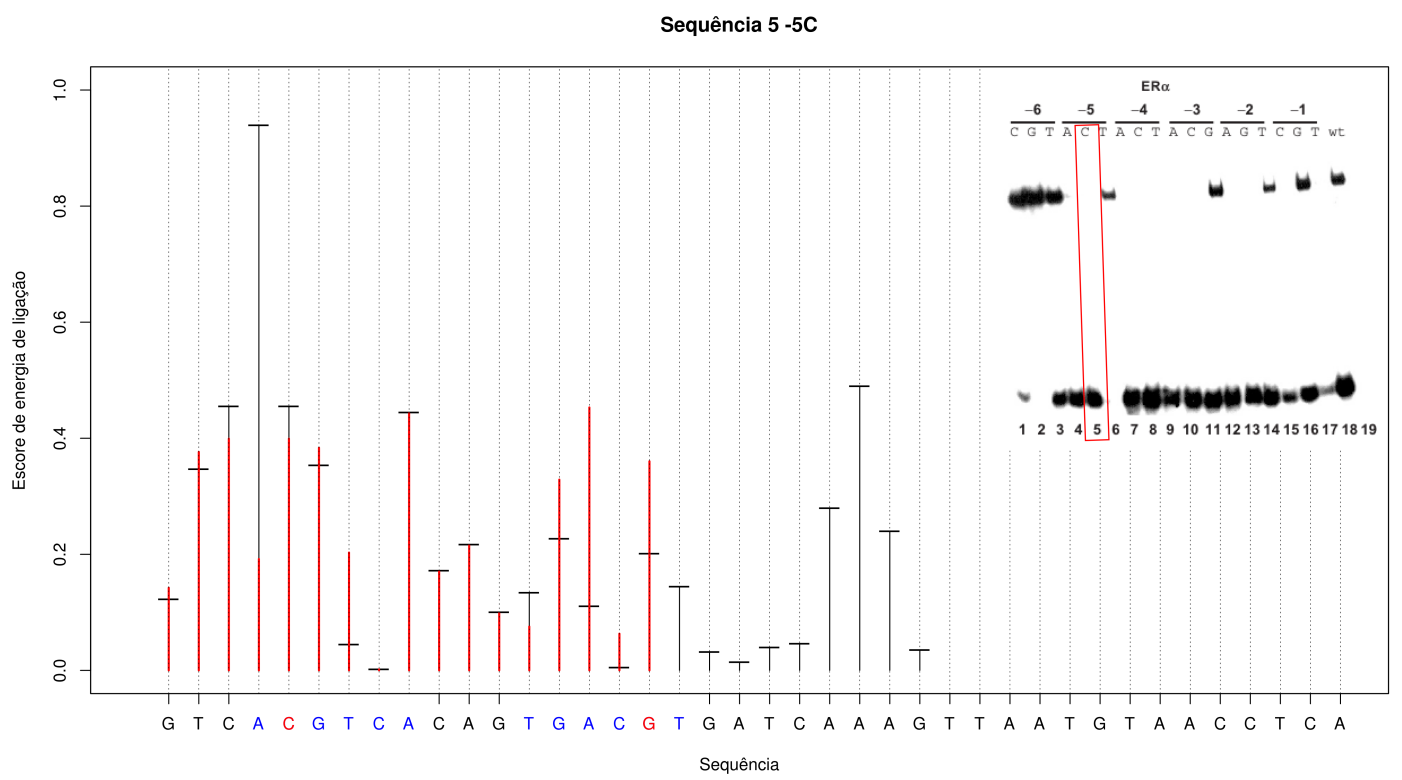

(e) Sequência 5: vitERE mutado nas posições -5C e +5G. A sequência reconhecida por ambas as héxades é ACGTCA.

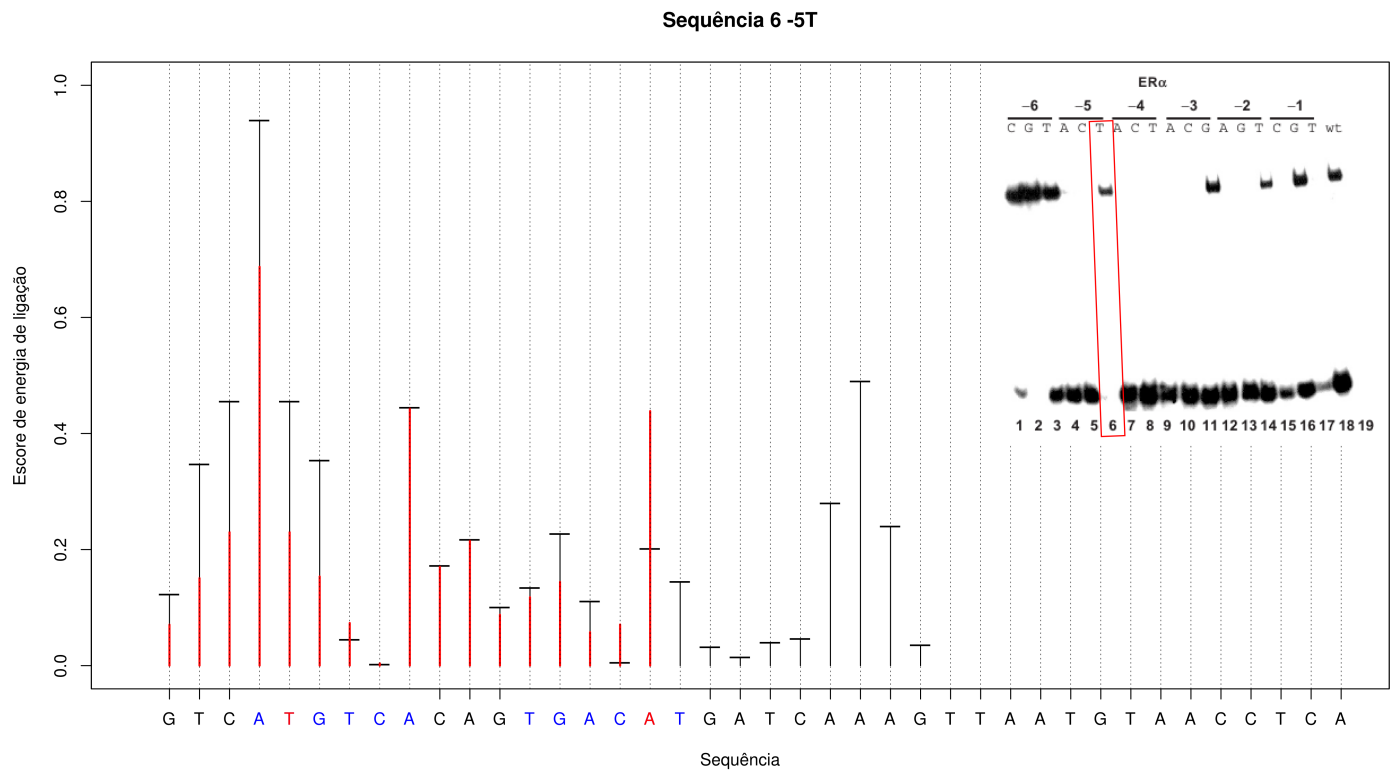

(f) Sequência 6: vitERE mutado nas posições $-5 \mathrm{~T}$ e $+5 \mathrm{~A}$. A sequência reconhecida por ambas as héxades é ATGTCA. 


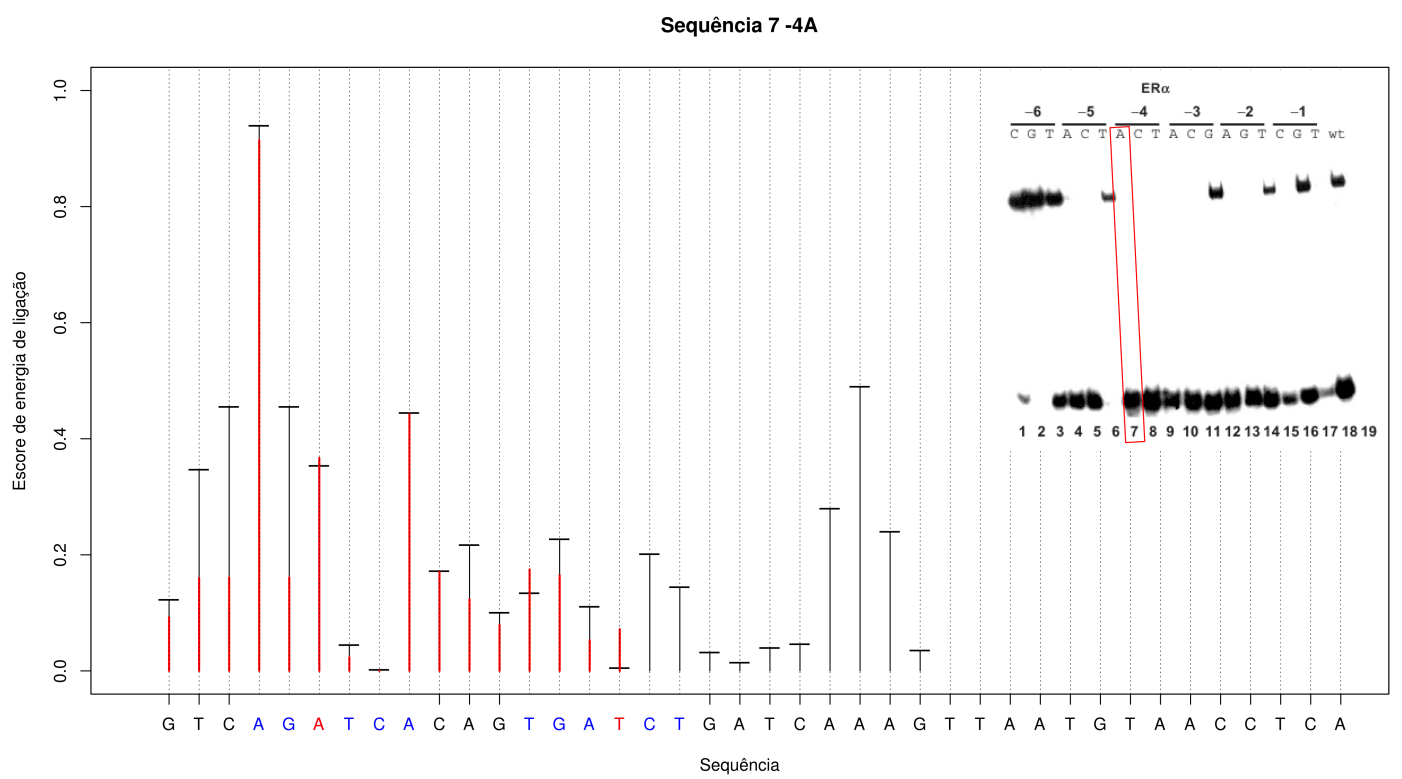

(g) Sequência 7: vitERE mutado nas posições $-4 \mathrm{~A}$ e $+4 \mathrm{~T}$. A sequência reconhecida por ambas as héxades é AGATCA.

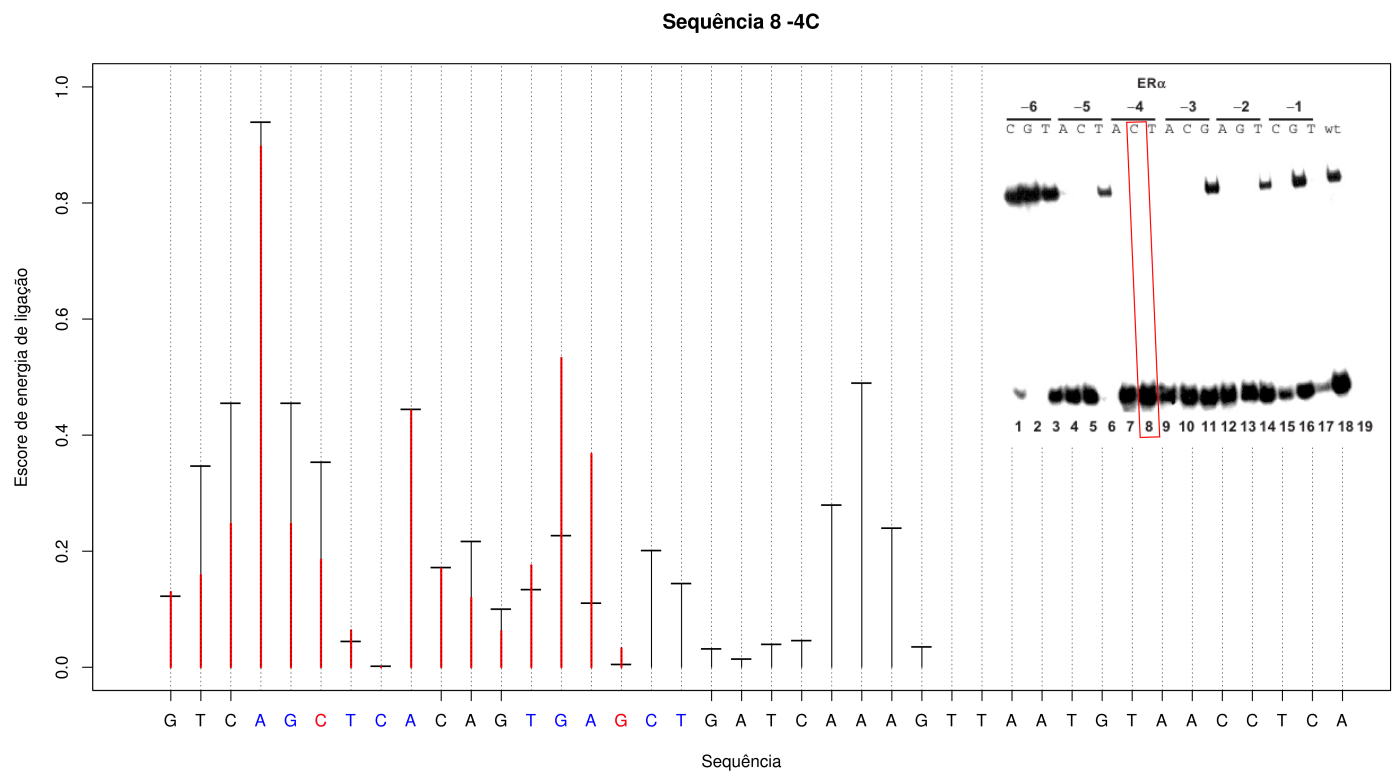

(h) Sequência 8: vitERE mutado nas posições -4C e +4G. A sequência reconhecida por ambas as héxades é AGCTCA. 


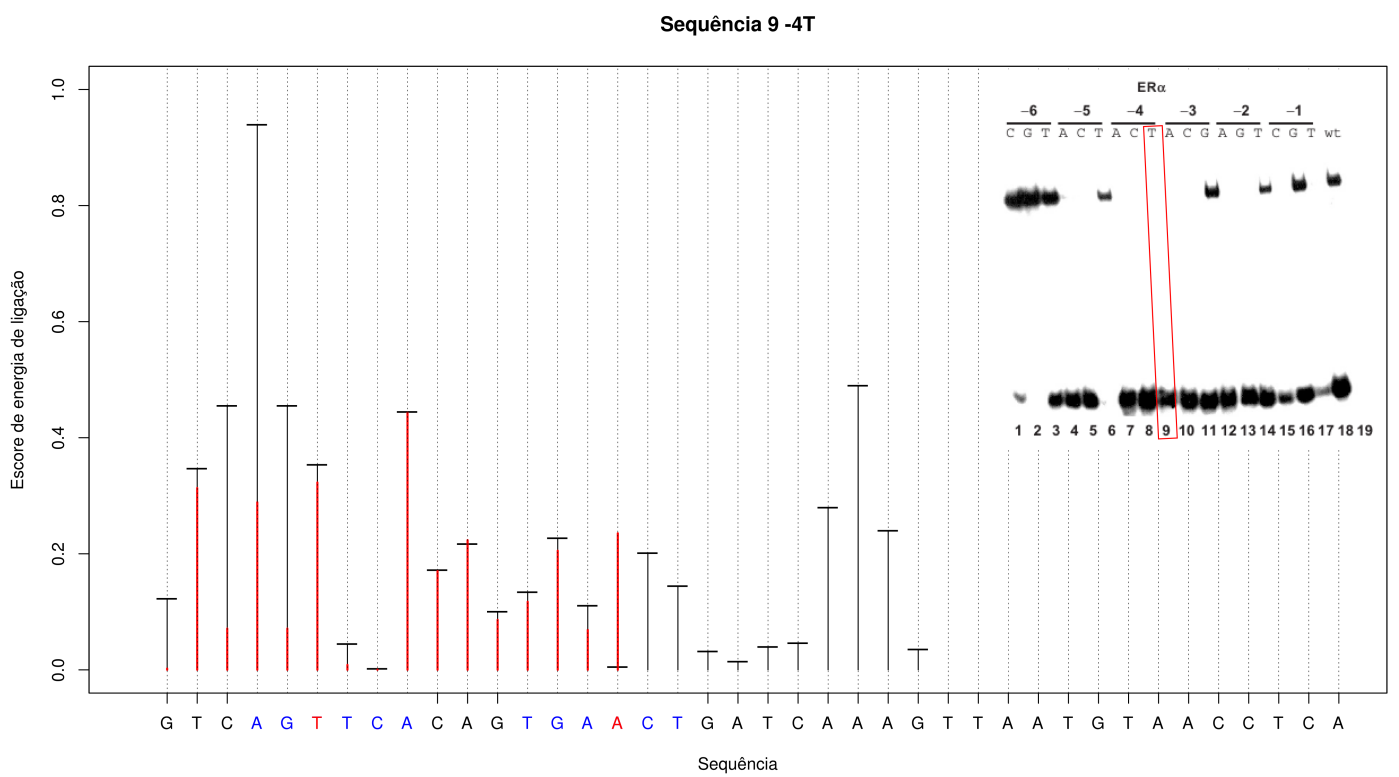

(i) Sequência 9: vitERE mutado nas posições $-4 \mathrm{~T}$ e +4A. A sequência reconhecida por ambas as héxades é AGTTCA.

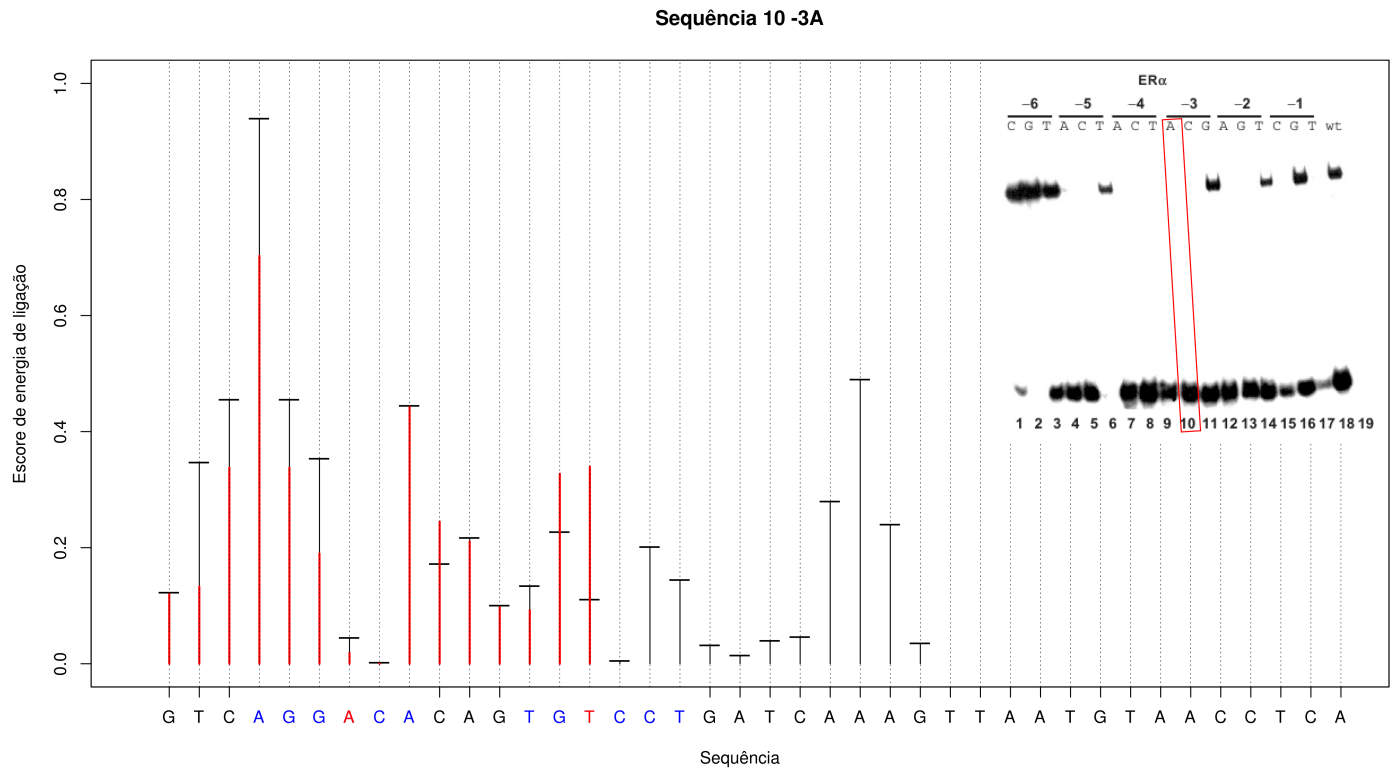

(j) Sequência 10: vitERE mutado nas posições -3A e +3T. A sequência reconhecida por ambas as héxades é AGGACA. 


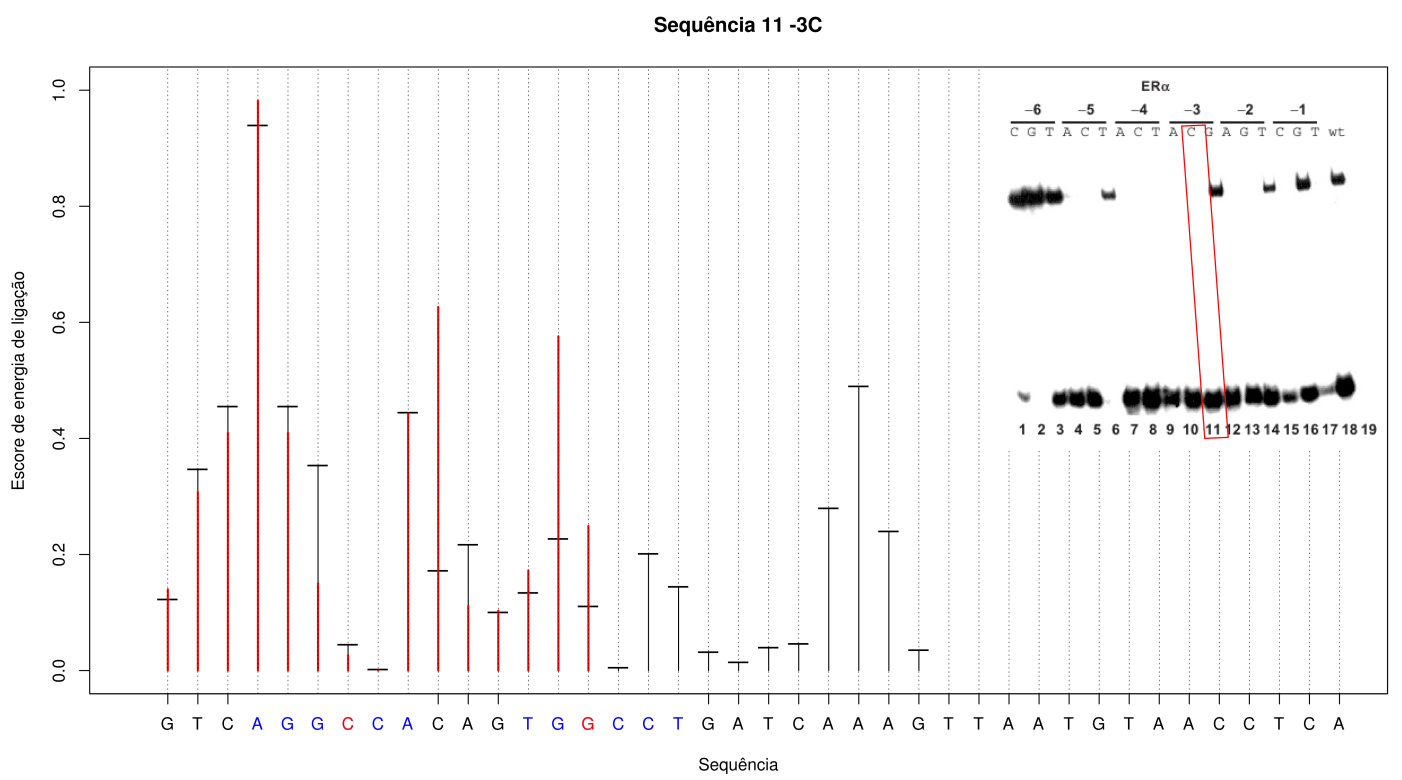

(k) Sequência 11: vitERE mutado nas posições -3C e +3G. A sequência reconhecida por ambas as héxades é AGGCCA.

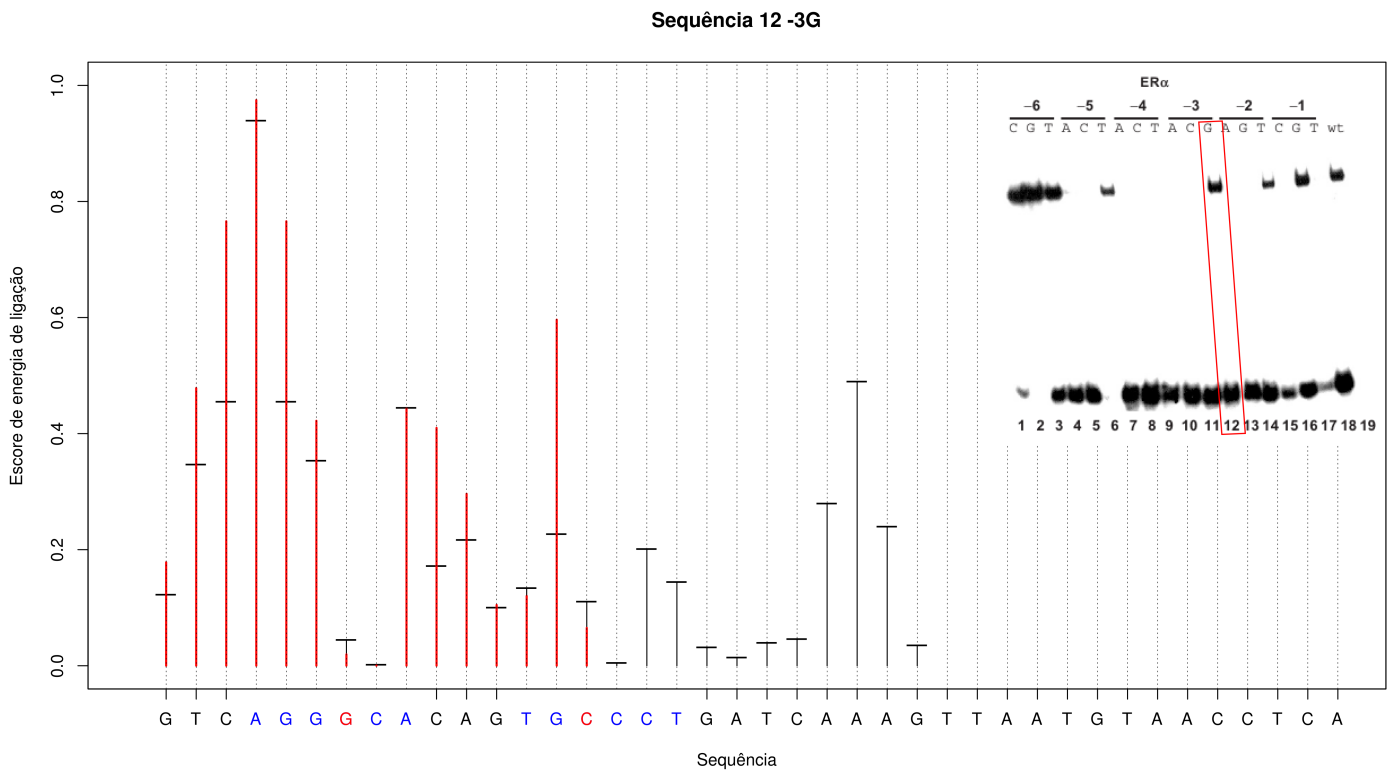

(1) Sequência 12: vitERE mutado nas posições -3G e +3C. A sequência reconhecida por ambas as héxades é AGGGCA. 


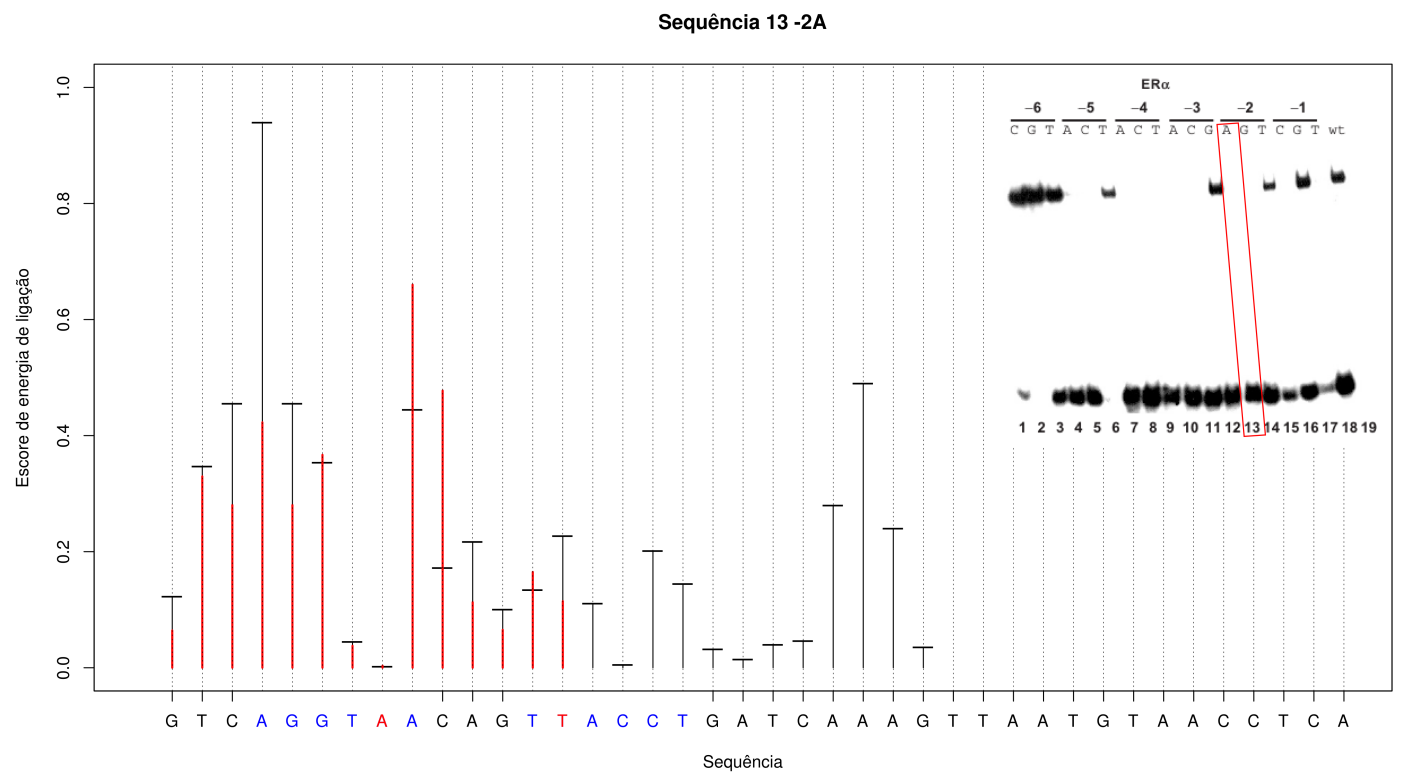

(m) Sequência 13: vitERE mutado nas posições $-2 \mathrm{~A}$ e $+2 \mathrm{~T}$. A sequência reconhecida por ambas as héxades é AGGTAA.

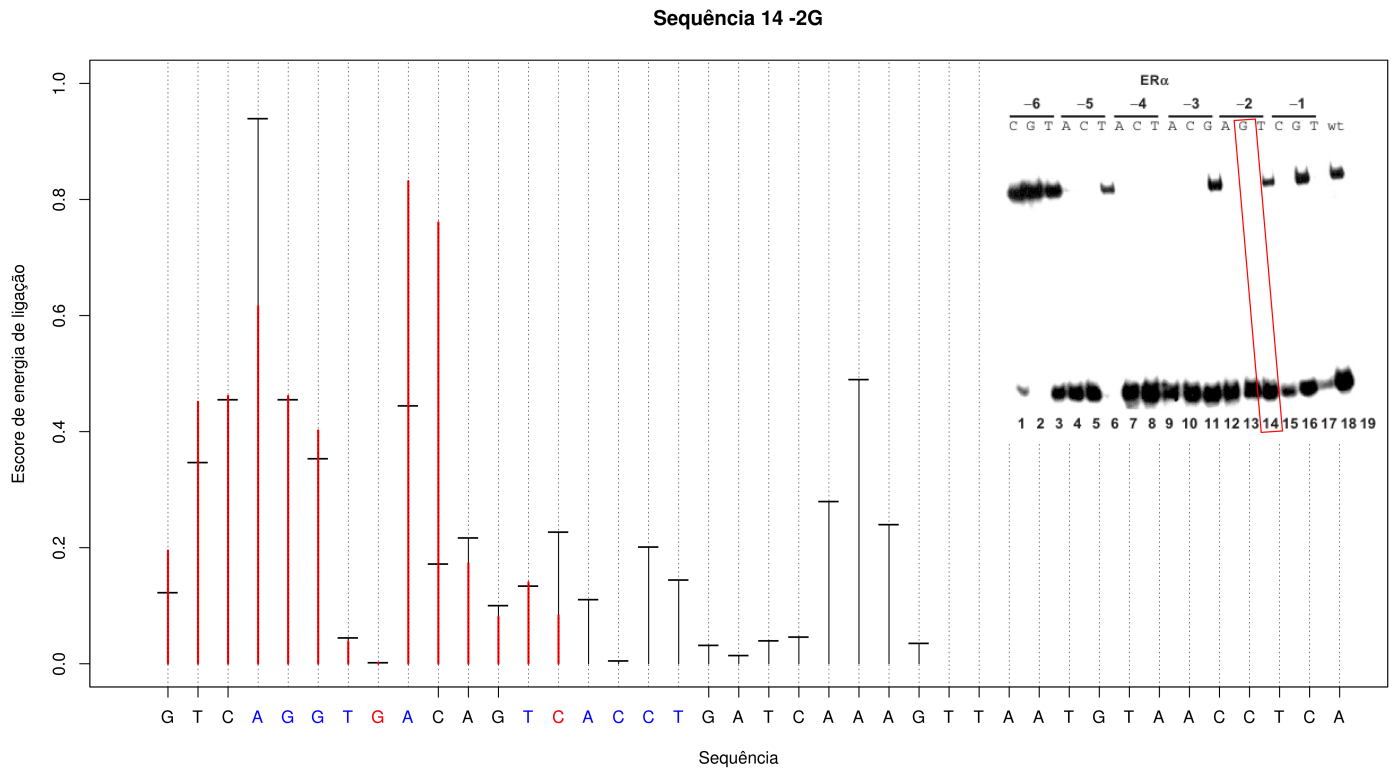

(n) Sequência 14: vitERE mutado nas posições $-2 \mathrm{G}$ e $+2 \mathrm{C}$. A sequência reconhecida por ambas as héxades é AGGTGA. 


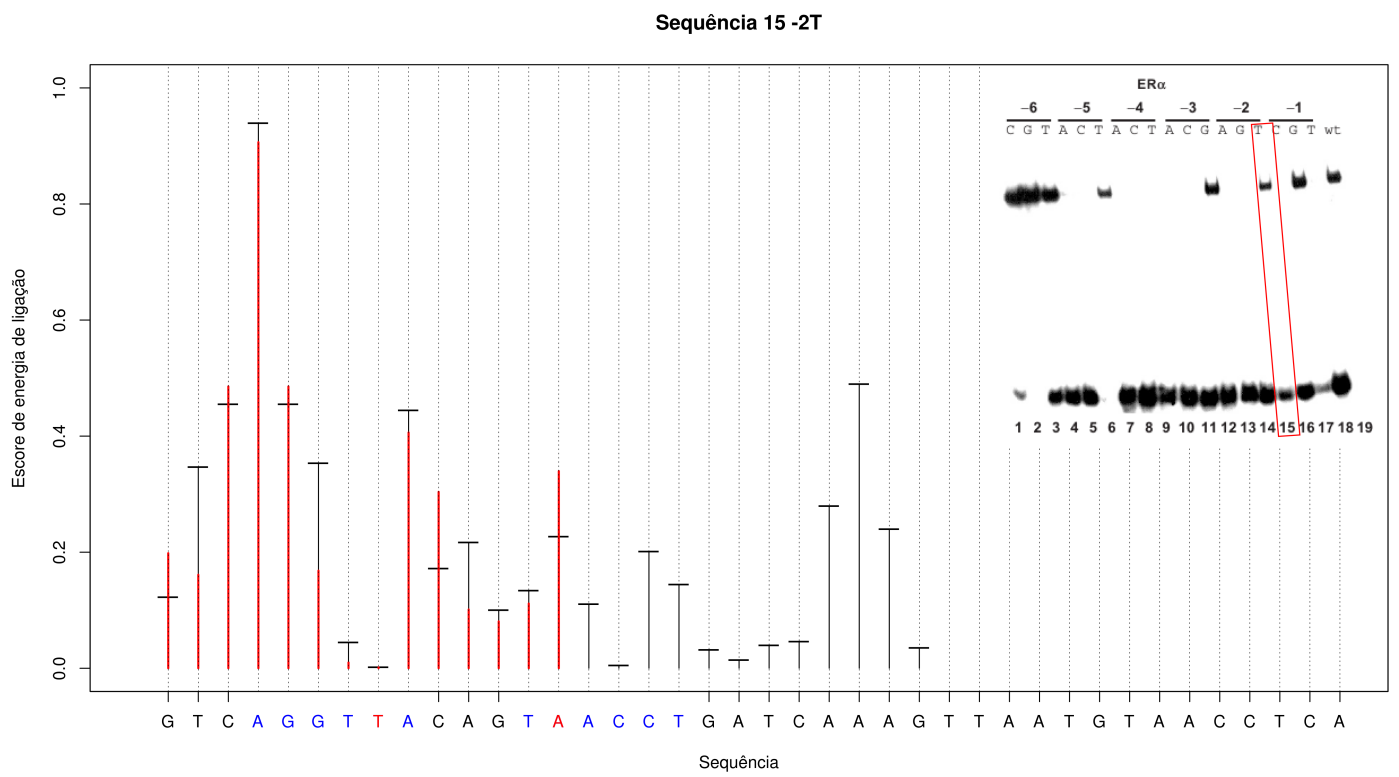

(o) Sequência 15: vitERE mutado nas posições $-2 \mathrm{~T}$ e $+2 \mathrm{~A}$. A sequência reconhecida por ambas as héxades é AGGTTA.

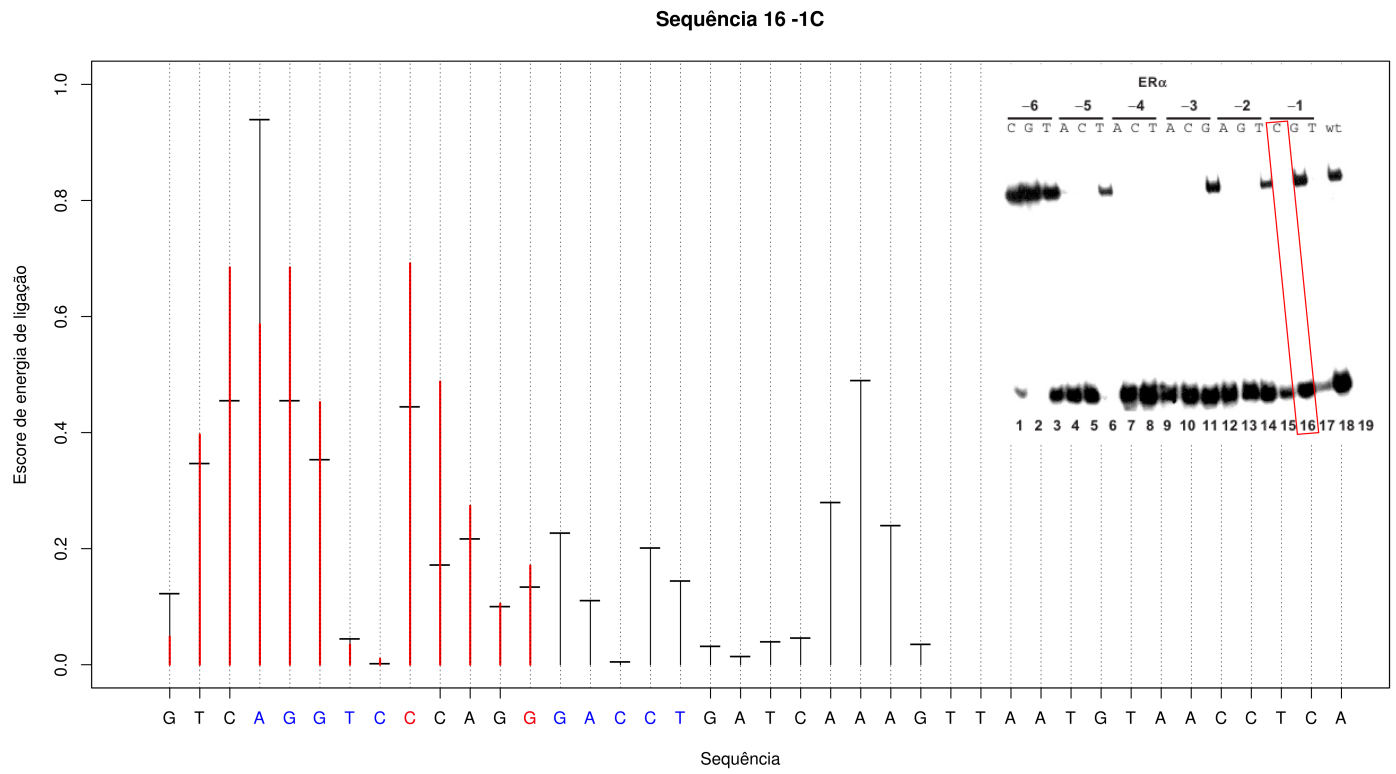

(p) Sequência 16: vitERE mutado nas posições -1C e +1G. A sequência reconhecida por ambas as héxades é AGGTCC. 


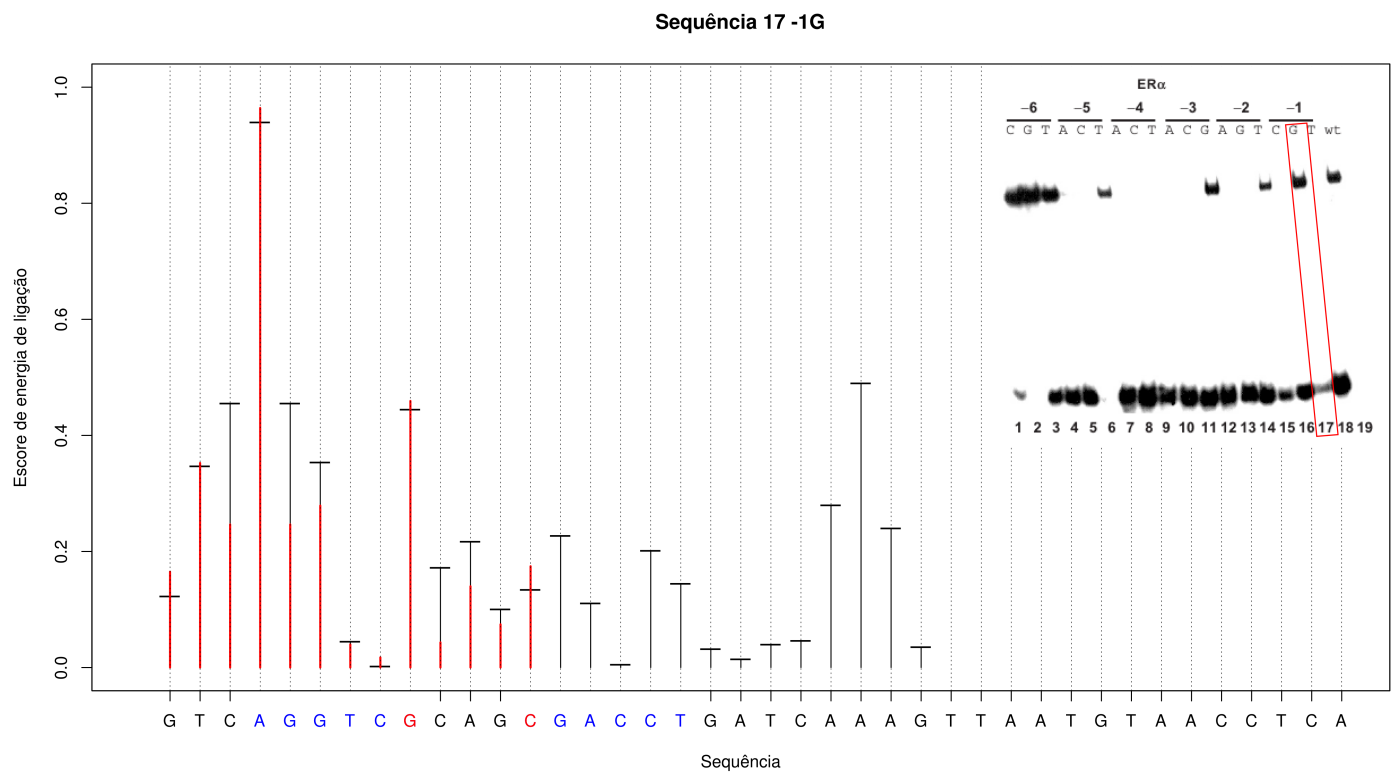

(q) Sequência 17: vitERE mutado nas posições -1G e +1C. A sequência reconhecida por ambas as héxades é AGGTCG.

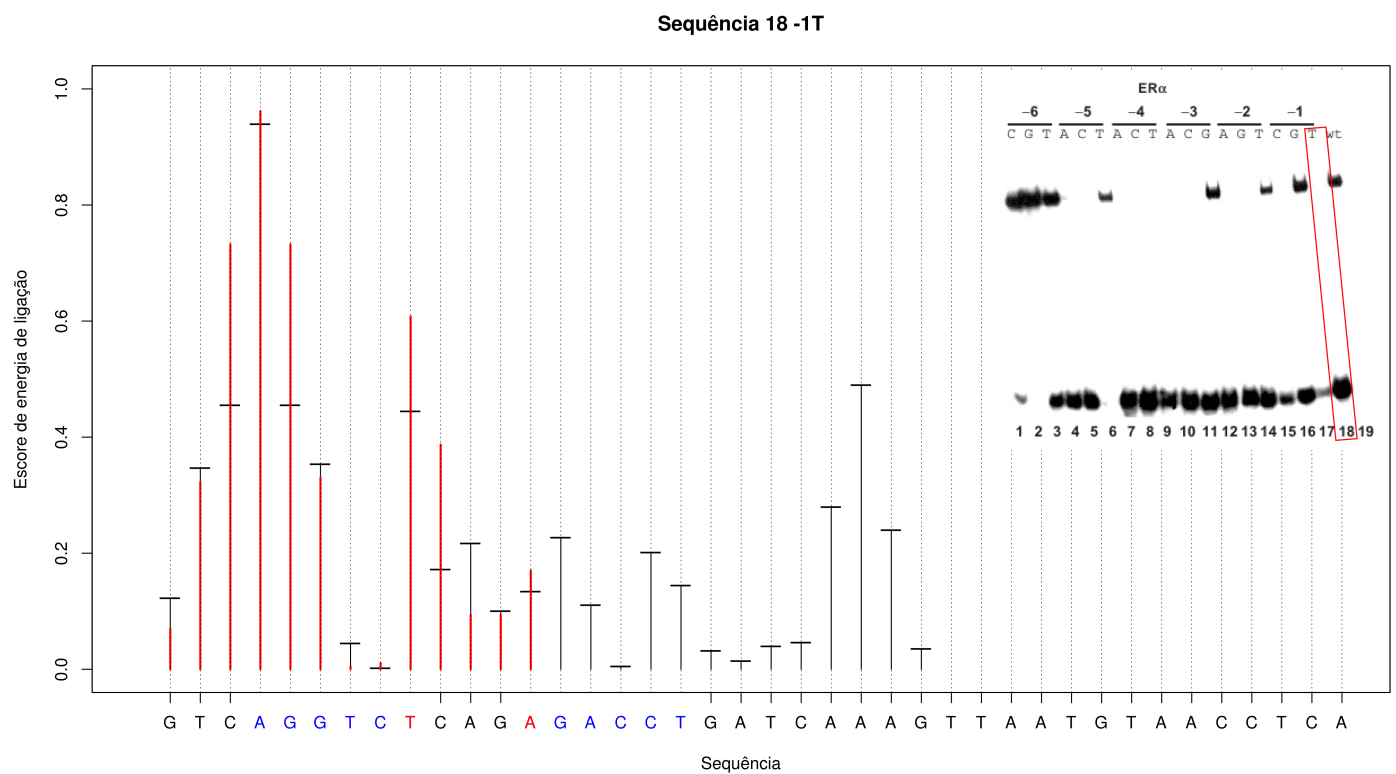

(r) Sequência 18: vitERE mutado nas posições -1T e +1A. A sequência reconhecida por ambas as héxades é AGGTCT. 
Nenhuma das mutações na primeira base das héxades foi capaz de impedir a complexação do ER- $\alpha$ no experimento de Nguyen. Este resultado foi previso também pelo TFBSAnalyzer, já que o pico de escore de ligação não foi perdido nas sequências mutantes 1 , 2 e 3 (Figuras 4.18a, 4.18b e 4.18c). Temos aí 3 positivos verdadeiros.

Já duas das mutações na segunda base foram capazes de impedir a complexação com ER- $\alpha: \mathrm{G} \rightarrow \mathrm{A}$ e $\mathrm{G} \rightarrow \mathrm{C}$. É interessante observar que estas mutações levam de uma base aceptora de elétrons para bases doadoras de elétrons, o que pode ser uma explicação para a perda de afinidade entre o DBD e o DNA. Essas duas mutações (sequências 4 e 5) levaram à perda dos picos de escore de ligação nas varreduras com TFBSAnalyzer (Figuras 4.18d e 4.18e), portanto temos dois negativos verdadeiros. No caso da terceira mutação nesta base, $\mathrm{G} \rightarrow \mathrm{T}$, ainda houve complexação no experimento de Nguyen, porém nota-se uma banda mais fraca do que a banda da sequência selvagem. Obtivemos um escore máximo de 0,69 para a sequência 6 (Figura 4.18f), bem mais baixo do que o dos outros. Dependendo do valor de corte, podemos ter um resultado falso-negativo ou positivo verdadeiro.

Para a terceira base, todas as mutações inibiram completamente a complexação no experimento de Nguyen, porém o TFBSAnalyzer predisse corretamente apenas o resultado da mutação $G \rightarrow T$ (sequência 9, Figura 4.18i), obtendo falsos-positivos nas outras duas sequências, 7 e 8 (Figura $4.18 \mathrm{~g}$ e 4.18h), cujas mutações eram $\mathrm{G} \rightarrow \mathrm{A}$ e $\mathrm{G} \rightarrow \mathrm{C}$.

As mutações $\mathrm{T} \rightarrow \mathrm{A}$ e $\mathrm{T} \rightarrow \mathrm{C}$ na quarta base inibiram a formação do complexo, mas a mutação $T \rightarrow G$ não o fez. No primeiro caso, observa-se um pico de 0,70 na varredura da sequência 10 (Figura 4.18j). Dependendo do valor de corte escolhido temos um resultado negativo verdadeiro ou falso-positivo. Já para a mutação $\mathrm{T} \rightarrow \mathrm{C}$ obtivemos um falso-positivo (Figura 4.18k), e para a mutação $\mathrm{T} \rightarrow \mathrm{G}$ um positivo verdadeiro (Figura 4.181).

Para a quinta base, apenas a mutação $\mathrm{C} \rightarrow \mathrm{T}$ não inibiu completamente a complexação no experimento de Nguyen, porém a intensidade da banda é bem menor do que a observada para a sequência selvagem. Para esta mutação, obtivemos um pico de escore de ligação (Figura 4.180). No caso das mutações $C \rightarrow A$ e $C \rightarrow G$, observamos uma queda no pico original, mas aparece um novo pico algumas bases adiante. No caso da primeira mutação, este novo pico vale 0,66 (Figura $4.18 \mathrm{~m}$ ), portanto podemos considerar o resultado como um negativo verdadeiro. Já para a segunda mutação, este pico vale 0,83 (Figura 4.18n). Este valor é bastante alto, a princípio classificando-se como falso-positivo. Porém se for escolhido um valor de corte acima de 0,83 , teríamos um negativo verdadeiro.

Finalmente, para a sexta base o TFBSAnalyzer predisse corretamente para duas mutações: inibição para $A \rightarrow C$ (Figura 4.18p) e complexação para $A \rightarrow G$ (Figura 4.18q). Já para a sequência 18 (Figura 4.18r), $\mathrm{A} \rightarrow \mathrm{T}$, o pico de escore de ligação foi mantido, portanto temos um falso-positivo.

Assim como foi feito para o heterodímero RAR-beta-RXR, é necessário definir um intervalo de valores de corte para realizar buscas por TFBSs. Os resultados acima foram sumarizados na Tabela 4.5, de maneira semelhante ao que foi feito com os re- 
sultados para $\operatorname{RAR} \beta$-RXR. Para cada sequência utilizada no experimento de mobilidade eletroforética feito por Nguyen, a tabela mostra se houve ou não complexação e qual o maior escore obtido na varredura. A partir desses dados foi possível traçar o gráfico da Figura 4.19, que mostra a porcentagem de acertos (TFBSs encontrados ou sequências comuns descartadas), falso-positivos (sequências comuns classificadas como TFBSs) e falso-negativos (TFBSs classificados como sequências comuns) para valores de corte variando entre 0 e 1 , com passo de 0.01 . Também foi construída a curva ROC para todos estes valores de corte Figura 4.20. A construção destas curvas é idêntica à construção feita na seção anterior, para RAR $\beta$-RXR (ver Tabela 4.4).

Tabela 4.5: Comparação entre os resultados de Nguyen e as varreduras realizadas com um dímero de ER$\alpha$. Na linha "Nguyen", as sequências que apresentaram complexação com o receptor são marcadas com uma O. Na linha "Maior escore" está anotado o maior valor de escore obtido na varredura da respectiva sequência.

\begin{tabular}{|c|c|c|}
\hline Sequência analisada & Nguyen & Maior escore \\
\hline wt & $\bigcirc$ & 0,94 \\
\hline seq1 & $\bigcirc$ & 0,91 \\
\hline seq2 & $\bigcirc$ & 0,97 \\
\hline seq3 & $\bigcirc$ & 0,97 \\
\hline seq4 & & 0,49 \\
\hline seq5 & & 0,49 \\
\hline seq6 & & 0,69 \\
\hline seq7 & & 0,91 \\
\hline seq8 & & 0,90 \\
\hline seq9 & & 0,49 \\
\hline seq10 & & 0,70 \\
\hline seq11 & $\bigcirc$ & 0,98 \\
\hline seq12 & & 0,97 \\
\hline seq13 & & 0,66 \\
\hline seq14 & $\bigcirc$ & 0,83 \\
\hline seq15 & & 0,91 \\
\hline seq16 & & 0,69 \\
\hline seq17 & & 0,96 \\
\hline seq18 & & 0,96 \\
\hline
\end{tabular}

Como esperado, observamos uma diminuição no número de falso-positivos com o aumento do valor de corte, em conjunto com um aumento do número de falsonegativos. Para o intervalo de valor de corte de 0,85 a 0,94 obteve-se a maior porcentagem de acertos, no valor de $73 \%$, com $21 \%$ de falso-positivos e $6 \%$ de falso-negativos. Na curva ROC, os melhores resultados estão entre 0,85 a 0,91 , portanto poderíamos selecionar o intervalo 0,85 a 0,91 como o de melhor desempenho. Porém, como discutido anteriormente, pode ser necessária uma solução de compromisso, caso seja de interesse encontrar TFBSs com interação mais fraca in vivo. Para ilustrar esta situação, podemos analisar a sequência mutante na posição -5 , com substituição de $G$ para T. Houve complexação com esta sequência, como mostra a coluna 6 do gel da Figura 4.15. Porém, o maior escore obtido na varredura desta sequência foi de 0,69 , portanto este TFBS seria um falso-negativo se realizássemos a busca com qualquer valor de corte 


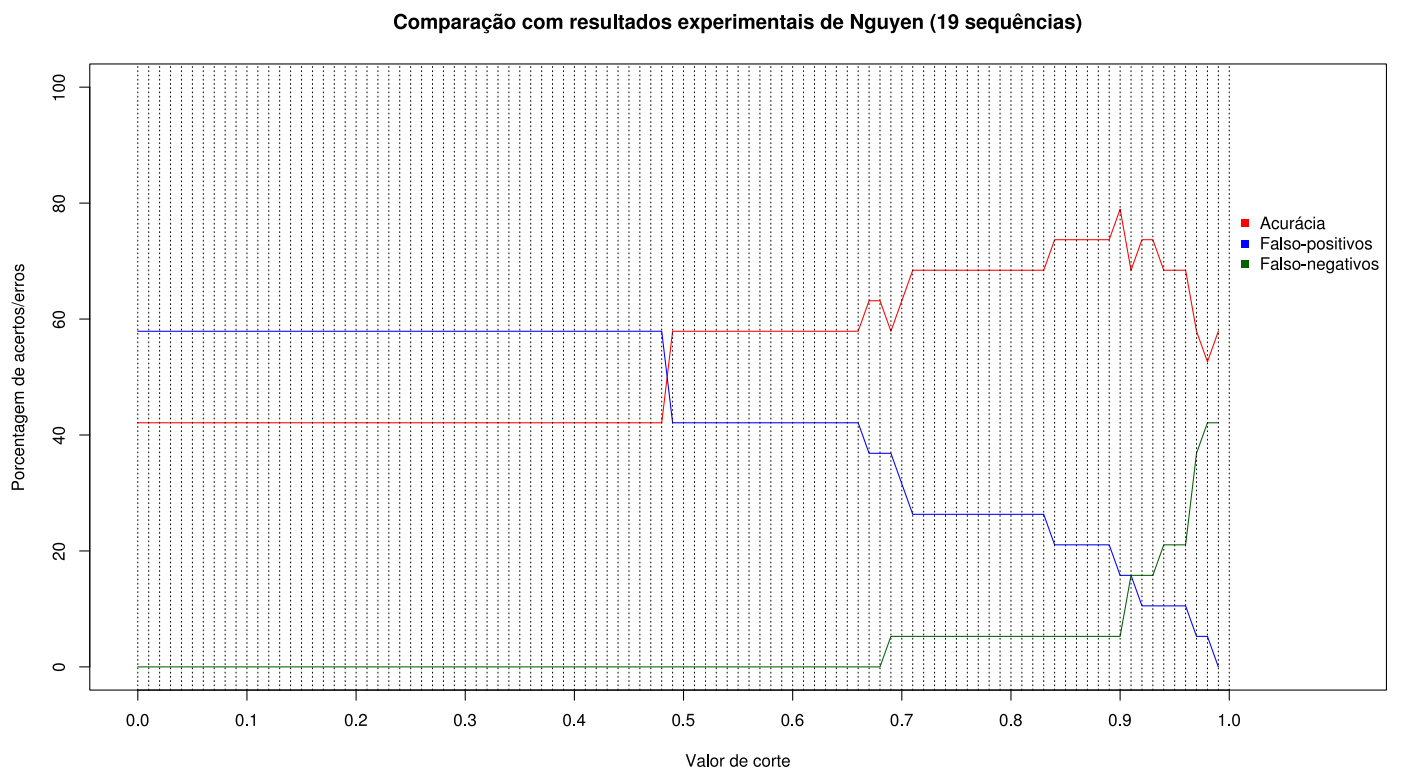

Figura 4.19: Comparação dos resultados experimentais de Nguyen com os resultados de varredura com um dímero de ER- $\alpha$, para vários valores de corte.

no intervalo 0,85 a 0,97 . Seria necessário diminuir a rigorosidade do valor de corte para pelo menos 0,69 a fim de encontrar este TFBS, porém aproximadamente $40 \%$ dos resultados seriam falso-positivos. Portanto, a escolha do intervalo de valores de corte deve ser feita com cautela, tendo em mente os efeitos que podem aparecer nos resultados obtidos. Ao comparar os resultados obtidos para o dímero de ER- $\alpha$ com aqueles obtidos para o heterodímero RAR- $\beta$-RXR, observamos que o algoritmo atual foi mais sensível a mutações em trincas de nucleotídeos do que a mutações pontuais. É possível que essa sensibilidade seja melhorada se forem incluídas informações entrópicas ao cálculo do escore de ligação.

\subsection{Comparação com resultados obtidos pelo TRANSFAC}

As sequências estudadas por Nguyen foram analisadas com a ferramenta TRANSFAC, a fim de comparar seu desempenho com o do TFBSAnalyzer. A Figura 4.21 compara a acurácia dos dois métodos, utilizando vários intervalos de corte, enquanto a Figura 4.22 compara suas curvas ROC.

Observa-se que a acurácia do TRANSFAC é um pouco maior do que a do TFBSAnalyzer, alcançando 78,95\% para vários valores de corte contra 73,68\% (Figura 4.21). Entretanto, ao comparar as curvas ROC (Figura 4.22) verificamos que o TFBSAnalyzer apresenta tanto sensibilidade quanto especificidade maiores do que o TRANSFAC, no intervalo $(0,85$ a 0,91$)$. A área sob a curva do TFBSAnalyzer é ligeiramente maior 


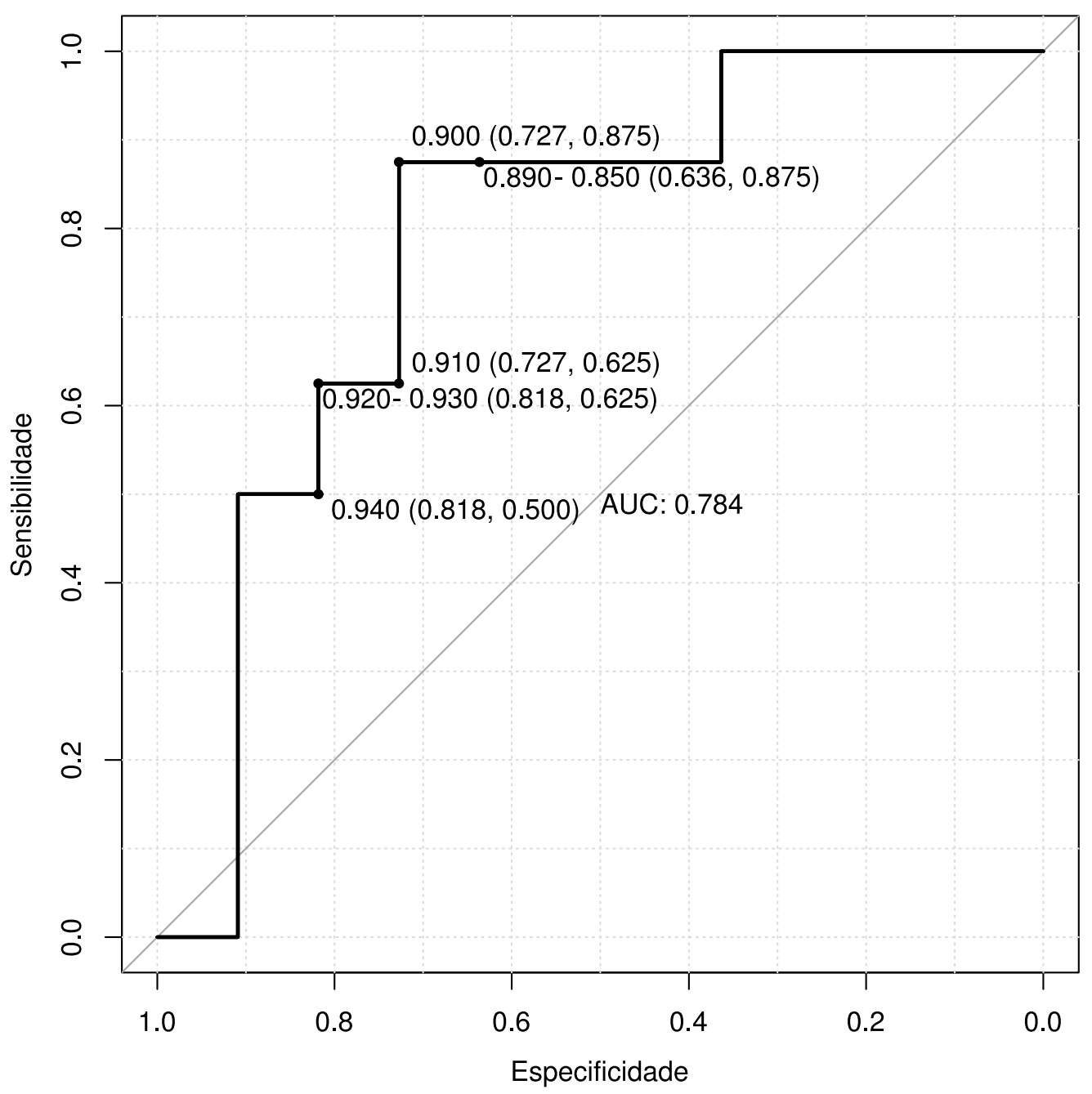

Figura 4.20: Curva ROC comparando os vários valores de corte testados com os resultados experimentais de Nguyen. O intervalo apresentado no melhor ponto consiste nos valores de corte que resultam neste ponto, bem como suas coordenadas (especificidade, sensibilidade). O valor AUC corresponde à área sob a curva (Area Under the Curve), que define a probabilidade de o método classificar um resultado positivo com escore maior do que o de um resultado negativo. 


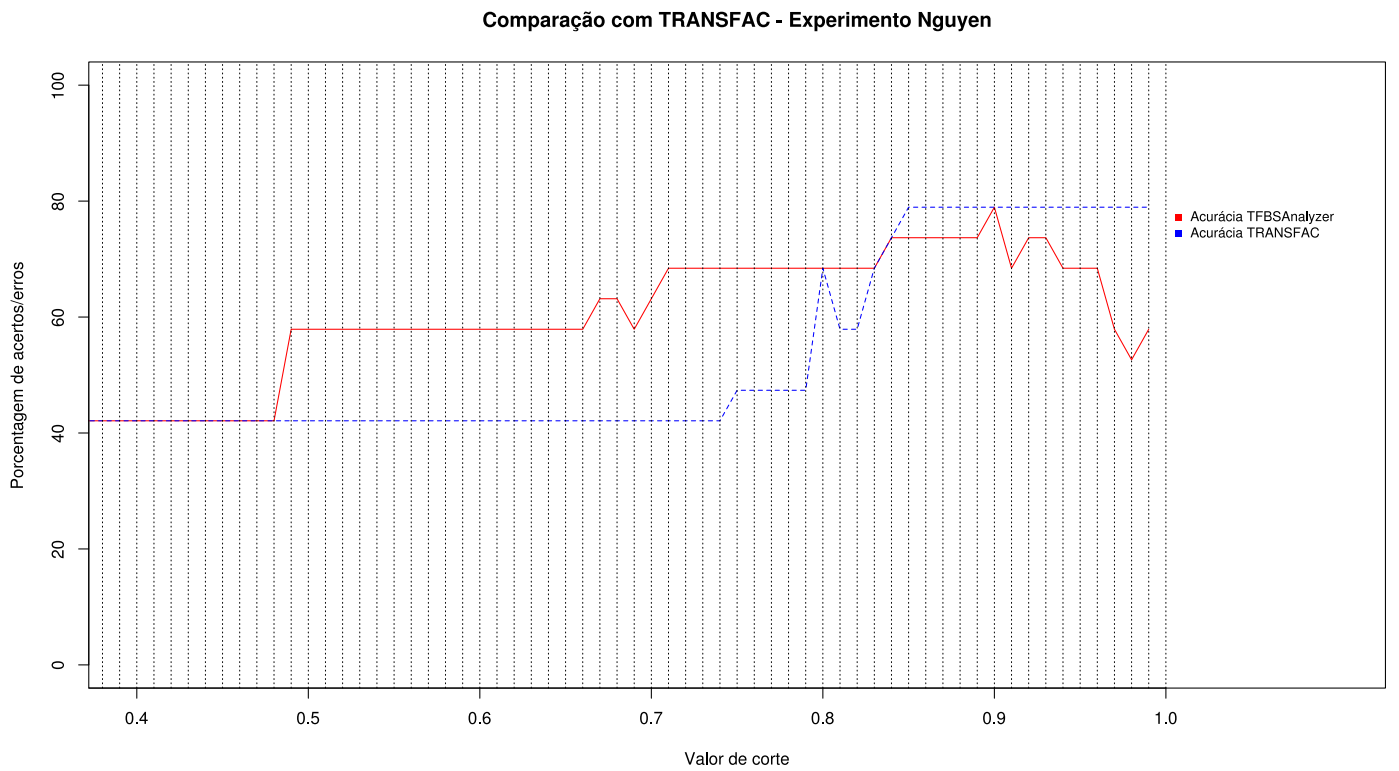

Figura 4.21: Comparação de desempenho da ferramenta TRANSFAC com o do TFBSAnalyzer em relação aos resultados experimentais de Nguyen.

que a do TRANSFAC, portanto a chance do primeiro classificar um resultado positivo acima de um negativo é maior do que a do segundo. Em geral, pode-se dizer que o TFBSAnalyzer alcançou um desempenho geral muito parecido com o do TRANSFAC. Entretanto, o método proposto é independente de técnicas experimentais dispendiosas e demoradas, portanto é mais vantajoso do que o TRANSFAC.

Não foi possível repetir a comparação para o heterodímero RAR- $\beta$-RXR pois a versão do TRANSFAC utilizada não dispunha de uma matriz específica para o RAR- $\beta$. Vale ressaltar que no caso do TRANSFAC, seria necessário realizar diversos experimentos (por exemplo de ChIP-seq) para obter uma matriz confiável e realizar a varredura da sequência de interesse, ao passo que para o TFBSAnalyzer foram necessárias apenas algumas horas de processamento para obter a distribuição de energia e utilizá-la para fazer a varredura. 


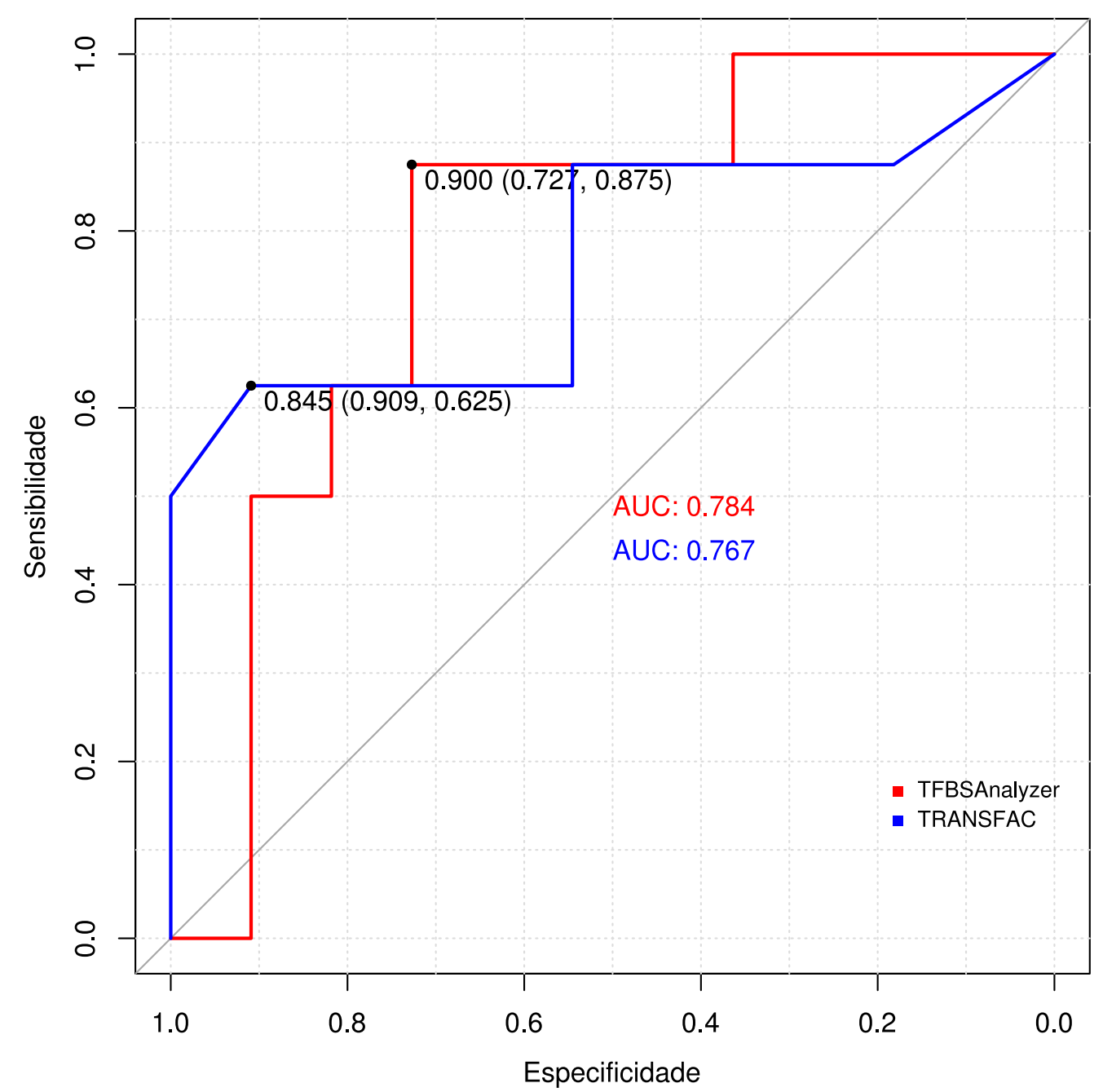

Figura 4.22: Curvas ROC comparando os resultados experimentais de Nguyen e os vários valores de corte para a ferramenta TRANSFAC e para o método proposto

\subsection{Desenvolvimento de um programa para automatização do método}

A fim de tornar a utilização do método proposto mais simples e direta, foi desenvolvido um programa em python capaz de receber um arquivo PDB com a descrição da estrutura do DBD de um receptor nuclear complexado a uma sequência de DNA e calcular a distribuição de energia de ligação para aquele receptor. Alguns parâmetros de entrada também podem ser definidos pelo usuário: 
- -n: tamanho do TFBS. Ao definir este número, o programa irá apagar as extremidades do DNA contido no complexo do arquivo PDB até alcançar o tamanho desejado;

- -d: distância máxima em angstrons que um nucleotídeo pode estar dos aminoácidos para ser considerado como pertencente ao TFBS. Esta opção é mutuamente excludente com a opção $-n$. Caso nenhuma das duas opções seja escolhida, subentende-se que o arquivo PDB contém um complexo cujo DNA já está no tamanho correto para representar o TFBS do fator de transcrição;

- -c: número de núcleos de processamento (cores) que o programa deve utilizar para paralelizar as tarefas. Por padrão, o programa utiliza metade dos cores existentes na máquina;

O programa utiliza a biblioteca yasara.py, a qual é disponibilizada em conjunto com o programa YASARA, e permite que um script em python controle uma thread do YASARA. Caso seja necessário, é possível parar o programa e retomar os cálculos do ponto em que ocorreu a parada. Para isto, basta executá-lo novamente com os mesmos parâmetros com os quais ele havia sido executado inicialmente, exceto os parâmetros de paralelização, os quais podem ser alterados. Para ilustrar a magnitude do tempo de execução do programa, um notebook pessoal Samsung Ativ Book 6, com um processador Intel Core i7-3635QM CPU 2.40GHz, de 4 núcleos e com Hyperthreading, com 8GB de memória, calculou a distribuição para o ER- $\alpha$ em aproximadamente $12,5 \mathrm{~h}$, utilizando 8 threads. Considerando que a distribuição para cada TF só precisa ser calculada uma vez, este tempo é bastante aceitável.

Também foi desenvolvido um programa para automatizar a varredura de sequências de DNA a partir da distribuição de energia calculada anteriormente para um ou mais TFs. Este programa também foi desenvolvido em python e depende apenas das bibliotecas padrão da linguagem. O programa recebe um arquivo fasta com a sequência de DNA e o(s) arquivo(s) texto contendo a(s) distribuição(ões) de energia calculada(s) para o(s) $\mathrm{TF}(\mathrm{s})$ de interesse. O programa possui as seguintes opções:

- -tfenergies: arquivo texto contendo a distribuição de energia calculada previamente para o primeiro TF;

- -spacer: usado para varredura com dímeros, define o número de nucleotídeos entre os TFBSs;

- -cutoffMin: valor em ponto flutuante entre 0 e 1 , define o valor mínimo para o qual as sequências são consideradas TFBSs;

- -cutoffMax: valor em ponto flutuante entre 0 e 1, define o valor máximo para o qual as sequências são consideradas TFBSs;

- -nmer: 1 para varredura com monômero, 2 para varredura com dímero; 
- -sym: <yes $>$ ou $<$ no $>$. Usado para dímeros. Se <yes $>$, o dímero será posicionado de forma simétrica (inverted repeat). Se $<$ no $>$, será posicionado de forma assimétrica (direct repeat);

- -het: arquivo texto contendo a distribuição de energia para um segundo TF, caso a varredura seja feita com um heterodímero. O arquivo definido em -tfenergies é utilizado na sequência upstream, enquanto o arquivo desta opção é utilizado na sequência downstream;

- -csv: nome do arquivo csv a ser gerado;

- -gff: nome do arquivo gff a ser gerado;

- -chr: nome do cromossomo, necessário para a geração do arquivo gff.

Assim como o programa de dsitribuição de energia de ligação, o programa de varredura pode ser parado e reiniciado. A varredura será continuada do ponto em que foi interrompida, desde que o programa seja executado com os mesmos parâmetros de antes. Para o mesmo notebook descrito antes, a varredura de todo o cromossomo 1, o qual possui 254235640 bases, foi executada em aproximadamente 5 minutos.

\subsection{Busca de TFBSs no genoma humano}

Com a automatização do método de varredura de sequências de DNA, análises em maior escala tornaram-se viáveis. Portanto, realizou-se uma varredura do genoma humano em busca de possíveis TFBSs reconhecidos por um dímero de ER- $\alpha$. Os dados do genoma humano foram obtidos através do website UCSC Genome Browser (Kent et al., 2002) (hg19). A partir dos arquivos fasta contidos neste pacote foi possível realizar a varredura de todos os cromossomos humanos ( 1 a 22 , X e Y), utilizando o intervalo de corte $(0,85: 0,91)$, o melhor encontrado pela comparação com os resultados experimentais de Nguyen (seção 4.3.2. Foram encontrados 11284484 TFBSs putativos, os quais foram submetidos a dois filtros biológicos: exclusão de ilhas CpG e filtragem pela distribuição de TFBSs ao longo do gene. As seções a seguir descrevem estas duas abordagens.

\subsubsection{Filtragem por exclusão de ilhas $\mathrm{CpG}$}

Um sítio CpG consiste em uma citosina adjacente a uma guanina em uma sequência de DNA. A notação CpG relembra que há apenas um fosfato entre os dois nucleotídeos e também distigue o dinucleotídeo do pareamento CG em fitas complementares. A citosina de um sítio CpG pode ser metilada para formar o composto 5-metilcitosina. Este processo pode levar ao desligamento de genes em mamíferos, nos quais $70 \%$ a $80 \%$ das citosinas CpG estão metiladas. Existem regiões no genoma que apresentam uma 
alta frequência deste dinucleotídeo, denominadas portanto ilhas CpG. Estas regiões também foram mapeadas e disponibilizadas no website UCSC Genome Browser (Kent et al., 2002), no arquivo cpgIslandExt.txt.gz. Caso um sítio encontrado pelo TFBSAnalyzer esteja localizado em uma ilha $\mathrm{CpG}$ é necessário desconsiderá-lo, já que ele não seria um TFBS biologicamente ativo. Os sítios encontrados no cromossomo 22 foram filtrados da maneira descrita, entretanto não houve grandes diferenças no resultado final: dos 254842 sítios encontrados no cromossomo 22 , apenas 4841 ( $\approx 19 \%)$ ocorrem em ilhas CPG. Considerando a sequência consenso do ER- $\alpha$ AGGTCA, este resultado pode ser decorrente de uma baixa afinidade deste NR com citosinas.

\subsubsection{Filtragem pela distribuição de TFBSs ao longo do gene}

O outro filtro biológico utilizado foi a distribuição de TFBSs ao longo do gene e de sua região regulatória mais provável. Koudritsky e Domany calcularam essa distribuição, através de dados de ChIP-chip, para nove TFs, dentre estes um NR (HNF4) (Koudritsky and Domany, 2008). A Figura 4.23 mostra o resultado obtido para cada um dos nove TFs, e pode-se observar que consiste em um pico em torno do sítio de iniciação da transcrição (TSS - Transcription Start Site) e uma distribuição uniforme nas outras regiões.

Através do pacote ChIPseeker, para linguagem $\mathrm{R}$, foi calculada a distribuição dos TFBSs encontrados na varredura do genoma com o dímero de ER- $\alpha$, apresentada na Figura 4.24. Observa-se que a distribuição de TFBSs em cada cromossomo humano se assemelha àquela encontrada por Koudritsky e Domany, com um pico em torno do TSS e uma distribuição uniforme nas outras regiões. A única exceção foi o cromossomo Y, cuja distribuição apresentou mais ruído do que as outras. Isso pode ser devido ao seu tamanho reduzido em comparação aos outros cromossomos, com apenas 307 genes contra uma média de 2500 genes/cromossomo. 

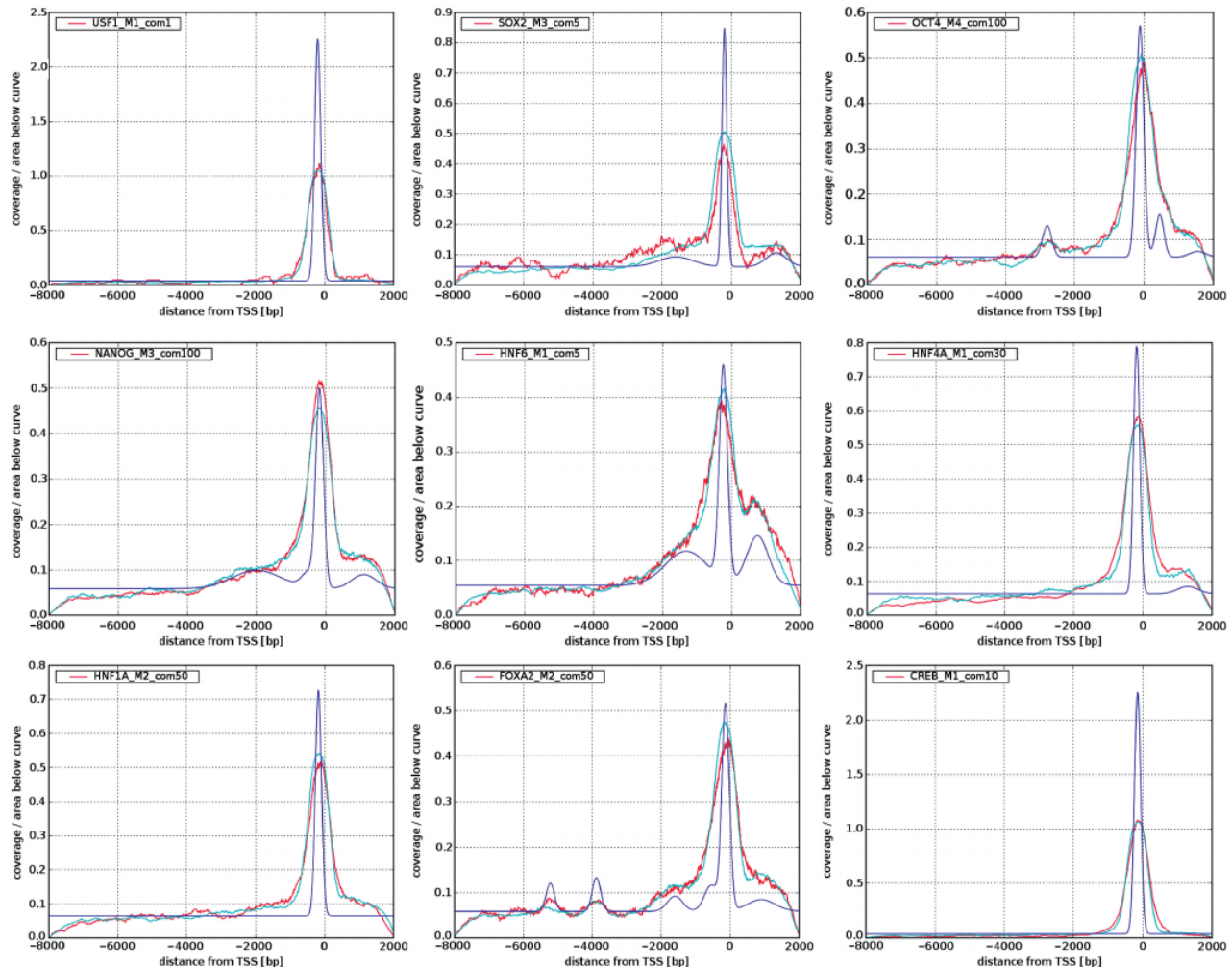

Figura 4.23: Em vermelho: dados experimentais de ChIP-chip; As outras curvas são específicas do trabalho de Koudritsky e Domany (distribuição de sítios de ligação deconvolucionada e ajustada em azul e simulação em ciano.) (Koudritsky and Domany, 2008)

Como um controle negativo, foi feita a varredura do cromossomo 22 utilizando o intervalo de corte $[0,0.1]$. A Figura 4.25 apresenta este resultado, e observa-se um pico negativo no TSS e uma distribuição uniforme nas outras regiões. Esta distribuição sugere que a grande quantidade de TFBSs no promotor pode ser um indicador da funcionalidade do TF in vivo. Este controle foi feito apenas para o cromossomo 22 pois a varredura neste intervalo de corte gera encontra uma grande quantidade de sítios, gerando arquivos muito grandes cuja análise requer muito tempo e recursos de memória computacional. 


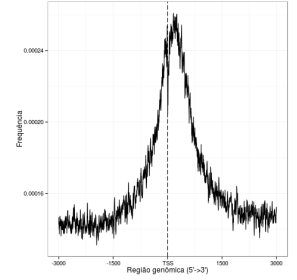

(a) Cromossomo 1

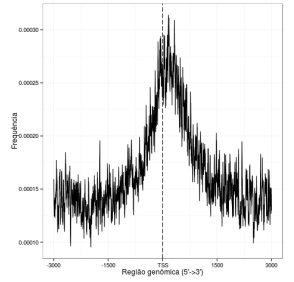

(e) Cromossomo 5

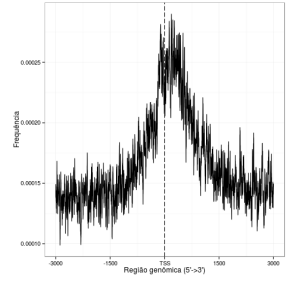

(i) Cromossomo 9

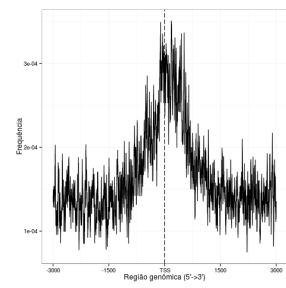

(m) Cromossomo 13

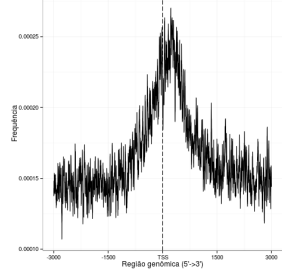

(q) Cromossomo 17

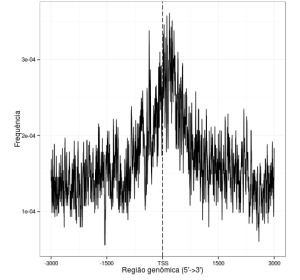

(u) Cromossomo 21

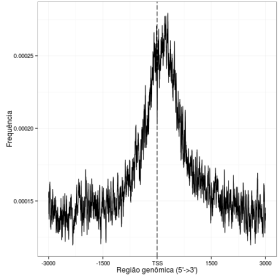

(b) Cromossomo 2

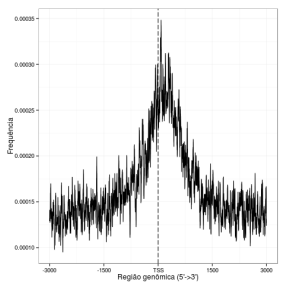

(f) Cromossomo 6

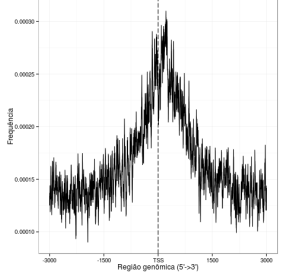

(j) Cromossomo 10

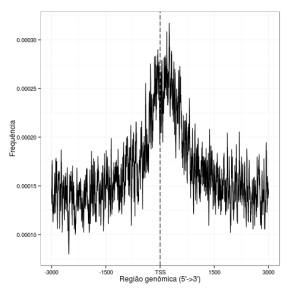

(n) Cromossomo 14

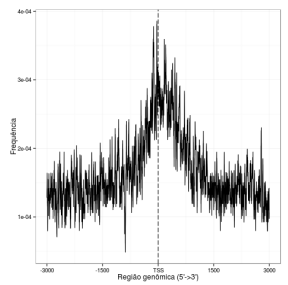

(r) Cromossomo 18

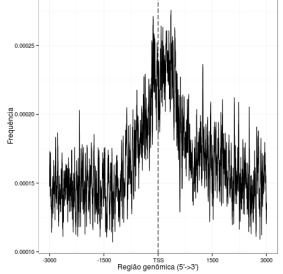

(v) Cromossomo 22

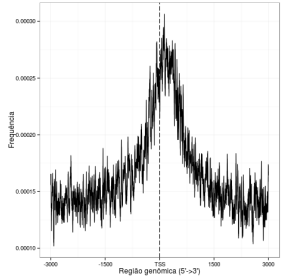

(c) Cromossomo 3

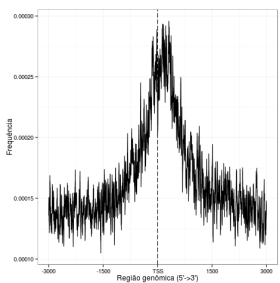

(g) Cromossomo 7

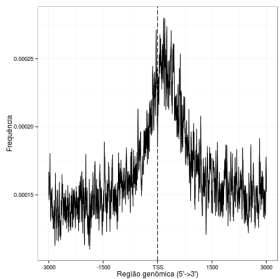

(k) Cromossomo 11

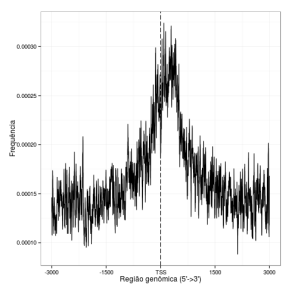

(o) Cromossomo 15

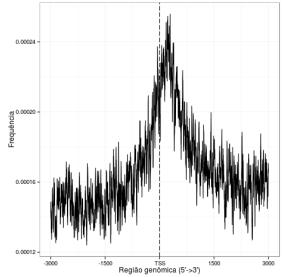

(s) Cromossomo 19

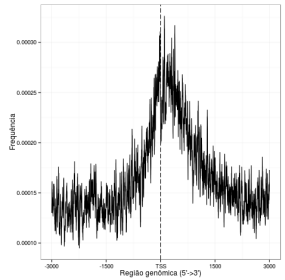

(w) Cromossomo X

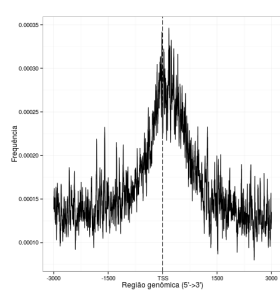

(d) Cromossomo 4

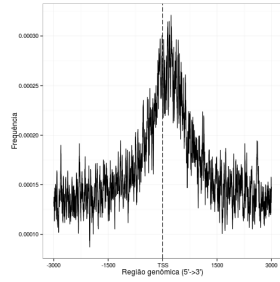

(h) Cromossomo 8

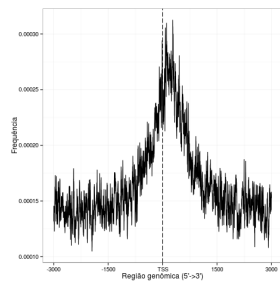

(1) Cromossomo 12

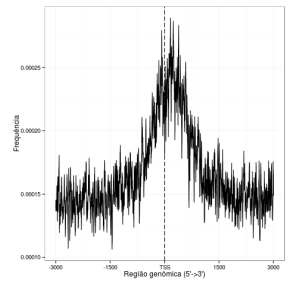

(p) Cromossomo 16

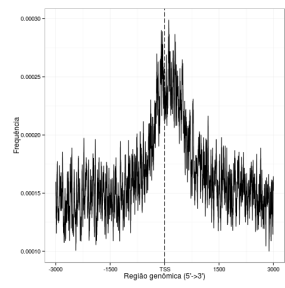

(t) Cromossomo 20

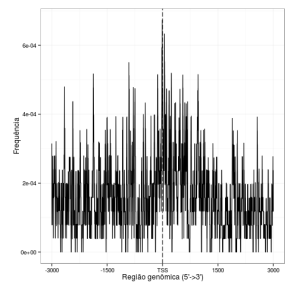

(x) Cromossomo Y

Figura 4.24: Distribuição de TFBSs encontrados pelo TFBSAnalyzer para um dímero de ER- $\alpha$, com IR3, no genoma humano 


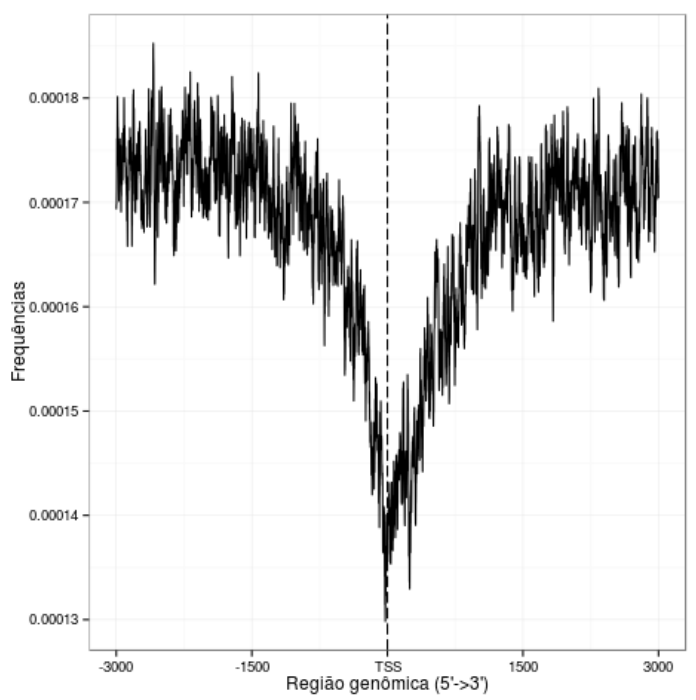

Figura 4.25: Controle da distribuição de TFBSs no cromossomo 22, considerando um intervalo de corte entre 0 e 0,1 .

Outro resultado importante para o projeto deste filtro está descrito no trabalho de (Ayers et al., 2014), no qual foi analisada a distribuição de TFBSs reconhecidos pelo receptor do hormônio tireoidiano (TR - Thyroid Hormone Receptor). A Figura 4.26 A mostra os eventos de ligação de TR observados nas diversas regiões genômicas e a composição do genoma humano. Se a sequência genômica seguisse uma distribuição uniforme, seria esperado encontrar mais TFBSs nas regiões maiores, ou seja, nas regiões intrônicas e intergênicas. Portanto, se $\approx 50 \%$ do genoma corresponde a introns, esperaria-se que $\approx 50 \%$ dos sítios para qualquer TF ocorressem nestas regiões. Porém a Figura 4.26 B mostra que a região promotora e a região regulatória downstream dos genes regulados por TR são muito mais enriquecidas de TFBSs do que as outras regiões, alcançando 12 vezes mais TFBSs do que o esperado para uma distribuição uniforme, enquanto que para regiões intrônicas são encontrados menos TFBSs do que o esperado.

Foi feita uma análise semelhante com os sítios encontrados para ER- $\alpha$ com o TFBSAnalyzer. O gráfico da Figura 4.27 mostra a distribuição desses sítios ao longo das regiões genômicas, a qual é semelhante àquela encontrada por Ayers, como mostrado na Figura 4.26 . 


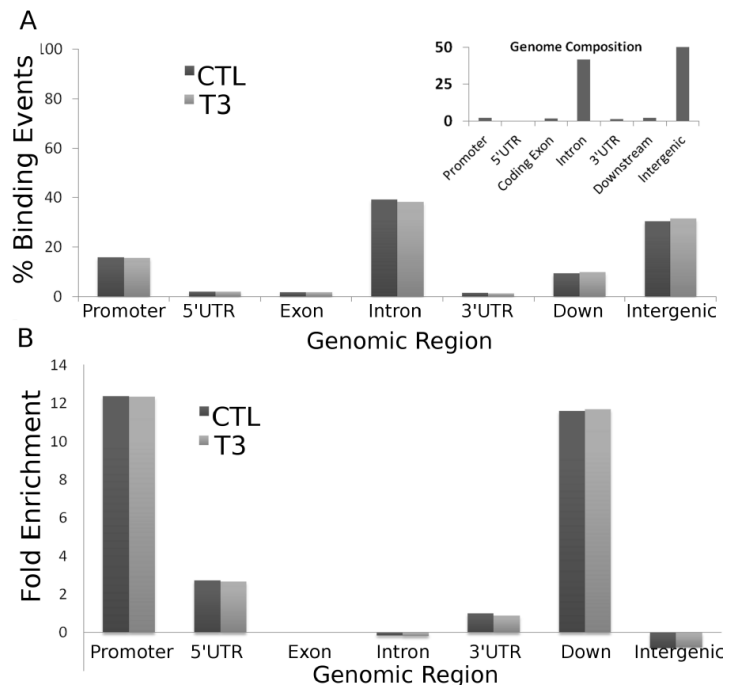

Figura 4.26: Caracterização de eventos de ligação genômica. A: Distribuição de picos de ligação de TR $\beta$ em regiões genômicas específicas, na presença (preto) e na ausência (cinza) de T3. B: Enriquecimento das regiões genômicas, em intervalos específicos, com relação à ligação de TR $\beta$. Figura adaptada de (Ayers et al., 2014).

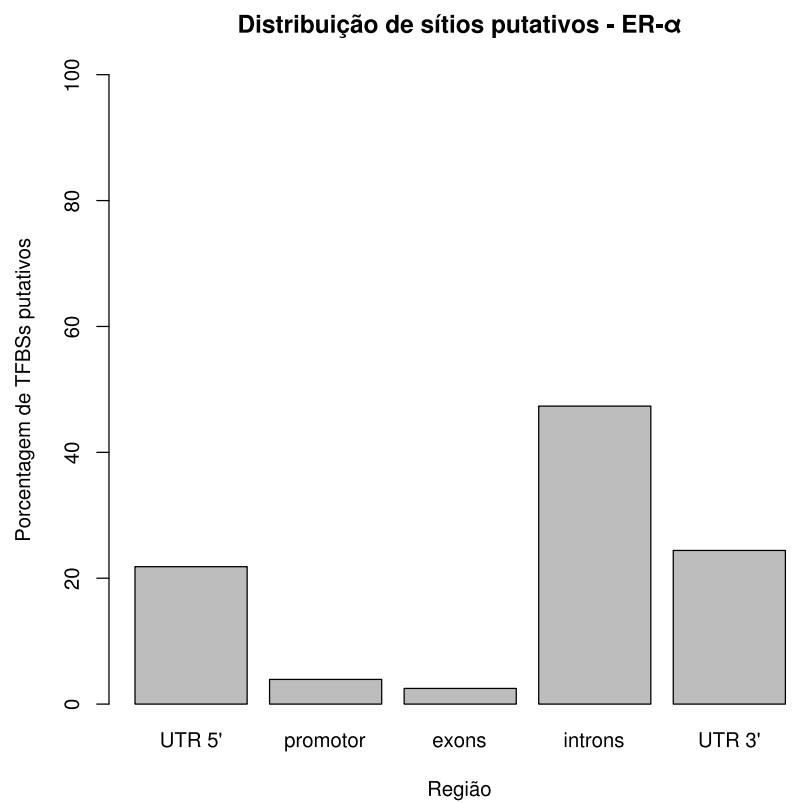

Figura 4.27: Distribuição de sítios putativos de ER- $\alpha$, obtidos com o TFBSAnalyzer. Considerou-se a região promotora como até $5 \mathrm{~kb}$ upstream do TSS e as regiões UTR5' e UTR3' como até 30kb upstream e downstream do gene, respectivamente. 
Em seguida calculou-se a distribuição de sítios normalizada pela composição genômica, ou seja, a porcentagem de sítios em cada região dividida pela sua abundância no genoma. Por exemplo, considerando o conhecimento atual, apenas $3 \%$ do genoma humano é formado por exons, logo seria esperado que 3\% dos sítios encontrados estejam em regiões exônicas. Porém, se $6 \%$ dos sítios encontrados estiverem em exons, temos um enriquecimento de sítios nessa região de 2 vezes. Essa ideia foi aplicada aos sítios putativos encontrados por regiões gênicas, e o resultado está apresentado na Figura 4.28, Observa-se que praticamente não houve enriquecimento em nenhuma das regiões estudadas. Porém esta distribuição corresponde a uma média entre as distribuições de todos os genes do grupo selecionado, pois cada um desses genes possui uma distribuição própria. Por exemplo, o gene que codifica a proteína ERR3 (Estrogen Receptor-Related Protein 3), cuja regulação por ER- $\alpha$ foi comprovada experimentalmente (Elangovan et al., 2011), possui uma distribuição bastante diferente desta média, apresentada na Figura 4.29. Ou seja, alguns dos genes selecionados com a varredura apresentam enriquecimento em regiões específicas.

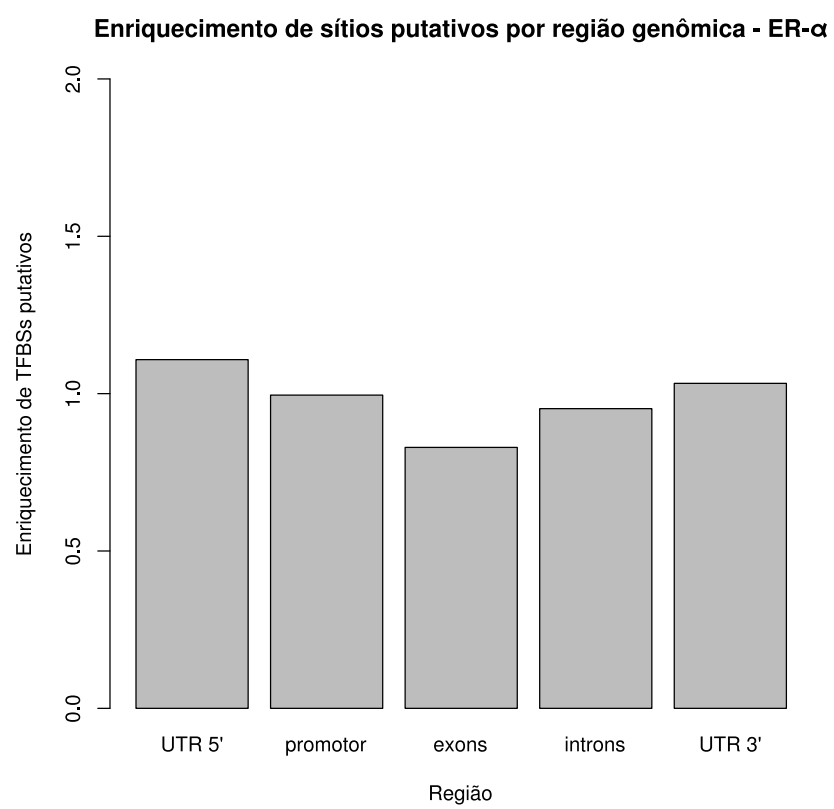

Figura 4.28: Enriquecimento de sítios putativos para ER- $\alpha$ por região genômica. Este gráfico compara a quantidade de sítios encontrados em cada região com a quantidade esperada dada a proporção que a região ocupa, em número de bases.

Para verificar esta hipótese, foi calculada a distribuição de sítios putativos na região promotora dos genes, apresentada na Figura 4.30. Este gráfico mostra que existem alguns genes com uma concentração alta de sítios na região promotora, enquanto a maioria dos genes tem uma concentração menor. Essa diferença fica ainda mais clara quando se analisa o gráfico da Figura 4.31, no qual está distribuído o enriquecimento 


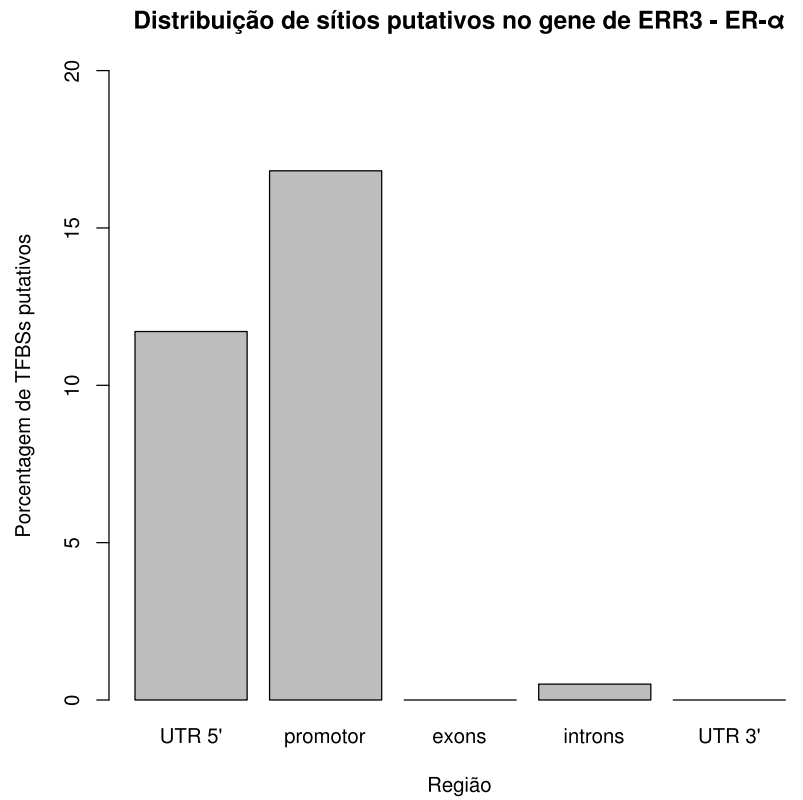

Figura 4.29: Enriquecimento de sítios putativos para ER- $\alpha$ por região para o gene codificante de ERR3.

de sítios na região promotora para cada gene. Observa-se que a grande maioria dos genes selecionados possui um enriquecimento menor do que 5 vezes. 


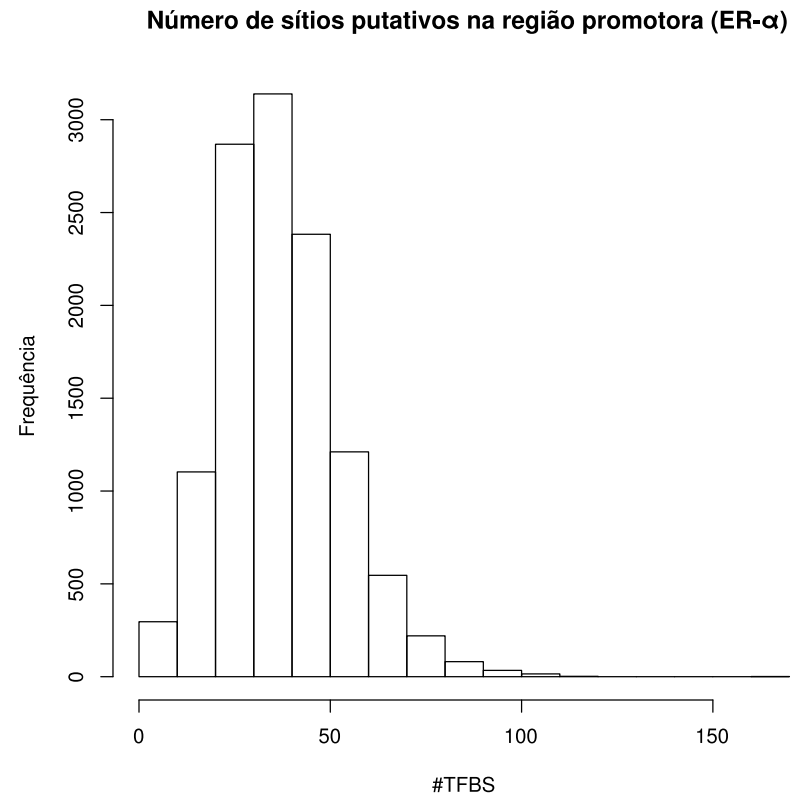

Figura 4.30: Quantidade de sítios putativos para ER- $\alpha$ nas regiões promotoras dos genes selecionados pela varredura do TFBSAnalyzer.

Enriquecimento de sítios putativos na região promotora (ER- $\alpha$ )

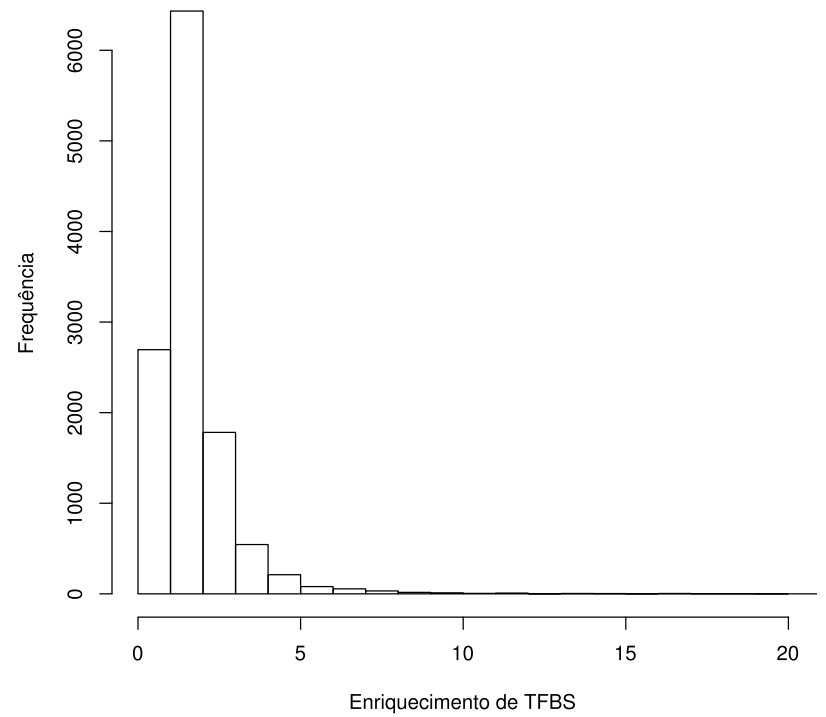

Figura 4.31: Enriquecimento de sítios putativos para ER- $\alpha$ nas regiões promotoras dos genes selecionados pela varredura do TFBSAnalyzer. 
Supondo que os resultados de (Ayers et al., 2014) possam ser aplicados também ao ER- $\alpha$, foram selecionados os genes cujo enriquecimento de TFBSs na região promotora fosse superior a 12 vezes o esperado para esta região devido à sua proporção no genoma. Este filtro foi bastante eficiente e selecionou apenas 223 genes. A partir desta lista foi possível verificar quais destes genes têm sua transcrição comprovadamente regulada pelo ER- $\alpha$.

\subsection{Análise dos resultados da varredura genômica}

Após selecionar uma lista com 223 genes com os filtros mencionados na seção anterior, o framework MetaCore foi utilizado para analisar este conjunto de dados. A Tabela A.1, no Apêndice A apresenta os 191 genes reconhecidos pelo MetaCore. Em seguida foi realizada uma busca pelos fatores de transcrição que regulam estes genes, com comprovação experimental. O resultado pode ser visto na Tabela 4.6. Foi construída uma rede com os genes selecionados nesta última análise, o qual está apresentado na Figura 4.32 .

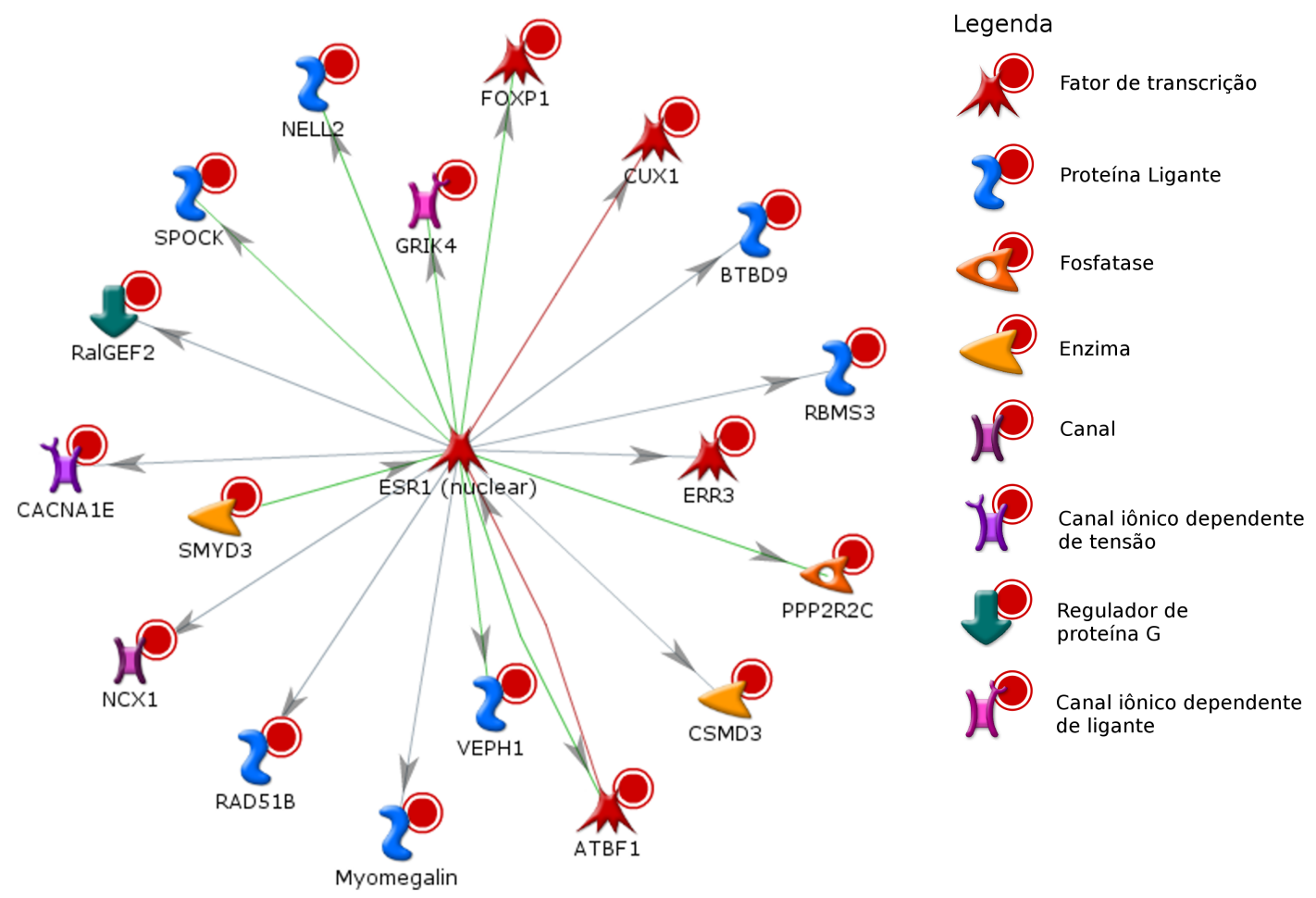

Figura 4.32: Genes da varredura genômica (filtrada por quantidade de sítios na região promotora) cuja transcrição é regulada por ER- $\alpha$. As setas verdes indicam ativação, as vermelhas inibição e as cinzas indicam que o efeito da interação não foi determinado experimentalmente. 
Tabela 4.6: Resultados da análise de enriquecimento de TFs que regulam o conjunto de gene selecionados a partir da varredura do genoma com TFBSAnalyzer e da filtragem por distribuição de TFBS na região promotora.

\begin{tabular}{|c|c|c|c|}
\hline Nome & processos GO & Nós & p-valor \\
\hline CREB1 & $\begin{array}{l}\text { diferenciação de neurônios, geração de neurônios, neurogênese, desenvolvimento do sis- } \\
\text { tema nervoso, desenvolvimento neuronal }\end{array}$ & 50 & $\begin{array}{l}1,98 \mathrm{e}- \\
134\end{array}$ \\
\hline Oct-3/4 & $\begin{array}{l}\text { regulação positiva da diferenciação de neurônios, regulação positiva do processo de bi- } \\
\text { osíntese de macromoléculas, desenvolvimento do sistema nervoso, regulação positiva de } \\
\text { processo metabólico de compostos com nucleobases, regulação positiva de processo celular }\end{array}$ & 23 & $9,79 e-61$ \\
\hline c-Myc & $\begin{array}{l}\text { regulação positiva de processo celular, regulação positiva de processo biológico, regulação } \\
\text { positiva do processo de biosíntese de macromoléculas, regulação positiva do processo de } \\
\text { biosíntese celular, regulação positiva do processo de biosíntese }\end{array}$ & 22 & $4,69 e-58$ \\
\hline $\begin{array}{l}\text { Receptor de } \\
\text { andrógeno }\end{array}$ & $\begin{array}{l}\text { regulação positiva de processo metabólico de compostos com nucleobases, regulação po- } \\
\text { sitiva de processo metabólico de compostos com nitrogênio, regulação positiva de diferen- } \\
\text { ciação de célula-tronco mesenquimal, regulação positiva do processo de biosíntese celular, } \\
\text { regulação positiva da transcrição de DNA }\end{array}$ & 21 & $2,23 e-55$ \\
\hline $\begin{array}{l}\text { ESR1 (ER- } \\
\alpha)\end{array}$ & $\begin{array}{l}\text { desenvolvimento de células de músculo estriado, desenvolvimento de célula muscular, im- } \\
\text { portação de íons de cálcio, importação de íons de sódio, transcrição do promotor de RNA } \\
\text { polimerase II }\end{array}$ & 18 & $2,27 \mathrm{e}-47$ \\
\hline GCR- $\alpha$ & $\begin{array}{l}\text { regulação da diferenciação do músculo cardíaco, geração de neurônios, neurogênese, re- } \\
\text { gulação positiva da diferenciação de células do músculo estriado, localização de proteínas } \\
\text { em túbulo-T }\end{array}$ & 17 & $1,04 \mathrm{e}-44$ \\
\hline p53 & $\begin{array}{l}\text { regulação positiva de processo celular, regulação positiva de processo biológico, regulação } \\
\text { negativa de processo celular, regulação negativa de processo biológico, desenvolvimento } \\
\text { do sistema nervoso }\end{array}$ & 13 & $4,18 \mathrm{e}-34$ \\
\hline RUNX2 & $\begin{array}{l}\text { regulação positiva de transcrição de DNA, regulação positiva do processo de biosíntese de } \\
\text { RNA, regulação positiva do processo de biosíntese de RNA metabólico, regulação positiva } \\
\text { de expressão gênica, regulação positiva de processo de biosíntese de macromoléculas }\end{array}$ & 12 & $1,82 \mathrm{e}-31$ \\
\hline NRSF & $\begin{array}{l}\text { transporte de íons de metal, detecção de estímulos mecânicos envolvidos na percepção } \\
\text { sensorial, regulação da diferenciação de células-tronco mesenquimais, detecção de estí- } \\
\text { mulos mecânicos, resposta a estímulos abióticos }\end{array}$ & 12 & $1,82 \mathrm{e}-31$ \\
\hline $\begin{array}{l}\text { TCF7L2 } \\
\text { (TCF4) }\end{array}$ & $\begin{array}{l}\text { regulação positiva de processo metabólico de compostos com nucleobases, regulação posi- } \\
\text { tiva de processo metabólico de compostos com nitrogênio, regulação positiva de processo } \\
\text { de biosíntese celular, regulação positiva de processo de biosíntese, regulação negativa de } \\
\text { processo de biosíntese de macromoléculas }\end{array}$ & 11 & $7,83 e-29$ \\
\hline NANOG & $\begin{array}{l}\text { regulação positiva de processo celular, regulação positiva de processo biológico, regula- } \\
\text { ção do desenvolvimento do tecido de músculo estriado, regulação do desenvolvimento de } \\
\text { tecido muscular, regulação do desenvolvimento de órgão muscular }\end{array}$ & 11 & $7,83 e-29$ \\
\hline LHX2 & $\begin{array}{l}\text { desenvolvimento neuronal, orientação da projeção neuronal, orientação de axônios, dife- } \\
\text { renciação de neurônios, axonogênese }\end{array}$ & 10 & $3,33 e-26$ \\
\hline STAT3 & $\begin{array}{l}\text { regulação positiva da transcrição de promotor de RNA polimerase II, regulação de neuro- } \\
\text { gênese, regulação negativa da transcrição de promotor de RNA polimerase II, regulação } \\
\text { positiva da transcrição de DNA, regulação do desenvolvimento do sistema nervoso }\end{array}$ & 10 & $3,33 e-26$ \\
\hline IRF1 & $\begin{array}{l}\text { regulação positiva de processo metabólico de compostos com nucleobases, regulação po- } \\
\text { sitiva de processo metabólico de compostos com nitrogênio, desenvolvimento do sistema } \\
\text { nervoso, regulação de processo metabólico de macromoléculas, regulação positiva de pro- } \\
\text { cesso de biosíntese celular }\end{array}$ & 10 & $3,33 e-26$ \\
\hline ETS1 & $\begin{array}{l}\text { regulação positiva de processo celular, regulação positiva de processo biológico, regulação } \\
\text { da formação de sinapse, regulação positiva de processo metabólico de compostos com } \\
\text { nucleobases, desenvolvimento do sistema nervoso }\end{array}$ & 10 & $1,39 \mathrm{e}-23$ \\
\hline IRF8 & $\begin{array}{l}\text { regulação negativa da transcrição de DNA, regulação negativa do processo de biosíntese } \\
\text { de RNA, regulação negativa do processo de biosíntese de RNA metabólico, regulação ne- } \\
\text { gativa da formação de sinapse, regulação negativa de processo celular de biosíntese de } \\
\text { macromoléculas, regulação negativa de expressão gênica }\end{array}$ & 9 & $1,39 \mathrm{e}-23$ \\
\hline SP1 & $\begin{array}{l}\text { desenvolvimento de órgãos, regulação da contração do músculo cardíaco via regulação de } \\
\text { liberação de íons de cálcio sequestrados, regulação da contração de músculo cardíaco via } \\
\text { sinalização de íons de cálcio, desenvolvimento de organismos multicelulares, regulação de } \\
\text { atividade de liberação de cálcio em canais sensíveis a rianodina }\end{array}$ & 9 & $1,39 \mathrm{e}-23$ \\
\hline $\begin{array}{l}\text { NF- } \\
\text { AT2(NFATC1) }\end{array}$ & $\begin{array}{l}\text { regulação positiva de processo biológico, regulação positiva de transcrição de DNA, regula- } \\
\text { ção positiva de processo de biosíntese de RNA, regulação positiva de processo metabólico } \\
\text { de RNA, regulação positiva de expressão gênica }\end{array}$ & 8 & $5,75 e-21$ \\
\hline SOX4 & $\begin{array}{l}\text { regulação positiva da transcrição de DNA, regulação positiva de processo de biosíntese de } \\
\text { RNA, regulação positiva de processo metabólico de RNA, regulação negativa de processo } \\
\text { celular, regulação de proliferação de células musculares cardíacas }\end{array}$ & 8 & $5,75 e-21$ \\
\hline FOXP2 & $\begin{array}{l}\text { regulação da expressão gênica, regulação positiva da proliferação de células tronco, via } \\
\text { de sinalização do fator de crescimento receptor- } \alpha \text { derivado de plaquetas, migração de } \\
\text { neurônios piramidais, regulação da proliferação de células-tronco }\end{array}$ & 8 & $5,75 e-21$ \\
\hline
\end{tabular}


Foram encontrados 18 genes cuja regulação por ER- $\alpha$ já foi comprovada experimentalmente, com um p-valor de 2,27e-47. Apesar de ser uma porcentagem pequena da quantidade de genes de entrada, deve-se levar em conta que provavelmente existem vários genes cuja regulação por ER- $\alpha$ ainda não foi experimentalmente verificada. Além disso, poderiam-se aplicar filtros diferentes à varredura inicial, envolvendo outros fatores como a acessibilidade ao sítio devido a fatores estéricos como a estrutura da cromatina. A análise também revelou que outros fatores de transcrição também foram encontrados como reguladores de alguns dos genes do conjunto, dentre eles o receptor de andrógeno. Como os genes não são regulados por um único fator de transcrição, este resultado era esperado.

\subsection{Análise de um NR de C. elegans}

Após os resultados obtidos para NRs humanos, seria interessante verificar a possibilidade de expandir o método para NRs de outros seres vivos. Apesar de a maioria dos NRs serem altamente conservados, mesmo entre espécies diferentes, muitos deles apresentam um motivo P-box específico, encontrado somente entre o gênero Caenorhabditis, sugerindo que este grupo de NRs pode ligar-se ao DNA de uma maneira diferente, como foi observado no trabalho de (Afonso et al., 2013). Este comportamento é objeto de estudo do Dr. Lucas Bleicher, pesquisador na Unviersidade Federal de Minas Gerais, UFMG. A distribuião de energia de ligação para um NR de C. elegans é de interesse para suas pesquisas pois poderia auxiliar no melhor entendimento da interação deste TF com o DNA. Já para o TFBSAnalyzer, aplicá-lo a este NR seria verificar sua funcionalidade para outros seres vivos. O complexo utilizado como ponto de partida foi construído utilizando modelagem por homologia, assim como foi feito para o RAR- $\beta$. A sequência utilizada foi a da proteína NHR-28, isoforma a (NP_001024388). Como estes eram complexos proteína-DNA, foi possível modelar a estrutura tanto do NR quanto do DNA, o que torna a estrutura do complexo mais confiável. O resultado da modelagem pode ser visto na Figura 4.33 .

A Figura 4.34 apresenta a distribuição de energia de ligação calculada para este TF. É interessante observar que a semelhança com as distribuições obtidas para os outros NRs modelos deste trabalho. Este resultado sugere que o TFBSAnalyzer pode ser aplicado para TFs de outros organismos. 


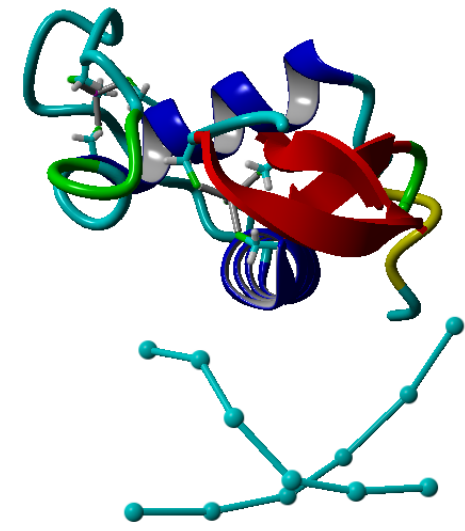

(a) Visão em laço

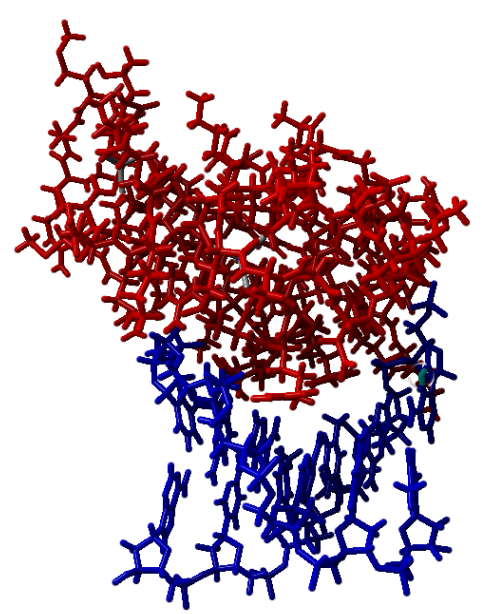

(b) Visão em bastão

Figura 4.33: Complexo NHR-28, isoforma a e DNA, obtido através de modelagem por homologia. (a) DBD de NHR-28, isoforma a em visão de laço. (b) DBD de NHR-28, isoforma a em visão de bastão.

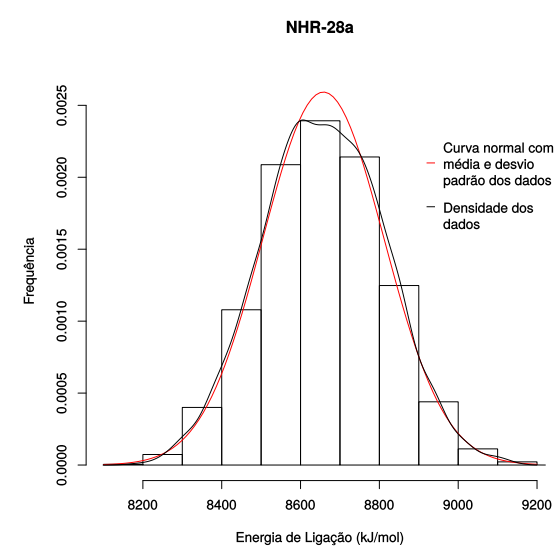

(a) NHR-28, isoforma a - Distribuição

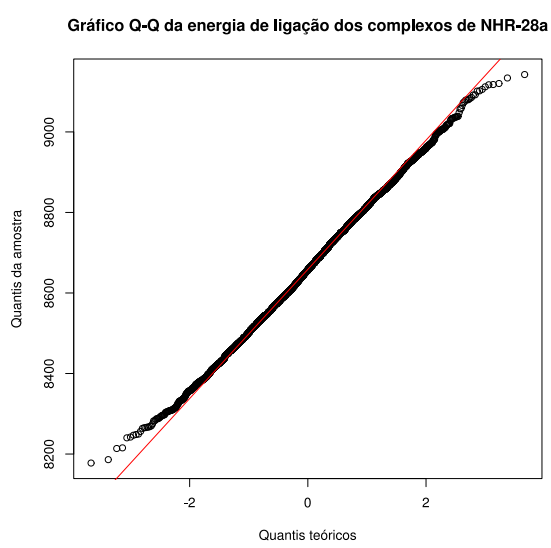

(b) NHR-28, isoforma a - Gráfico QQ

Figura 4.34: Distribuição de energia de ligação e gráfico quantil-quantil para avaliação da normalidade dos dados. (a) Histograma da energia de ligação dos complexos entre NHR-28, isoforma a, e DNA de 6bp e (b) respectivo gráfico quantil-quantil.

\subsection{Análise estrutural dos complexos}

Devido à maior ocorrência de falso-positivos no caso do ER- $\alpha$, as estruturas dos complexos envolvidos no experimento de Nguyen foram analisadas, a fim de verificar possíveis inconsistências. A seguir estão apresentados todos os 19 complexos avaliados (1 selvagem e 18 mutações), classificados como positivos verdadeiros (Figura 4.35), negativos verdadeiros (Figura 4.37), falso-positivos (Figura 4.39) ou falso-negativos (Figura 4.40, Os resultados foram resumidos na Tabela 4.7. 


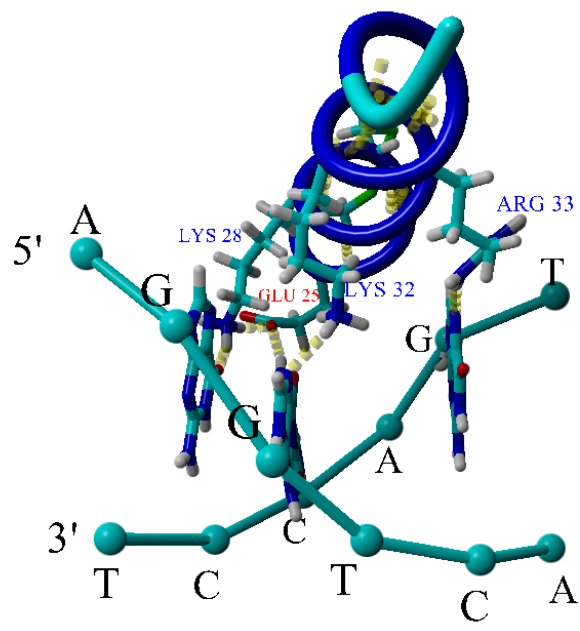

(a) Complexo AGGTCA (selvagem)

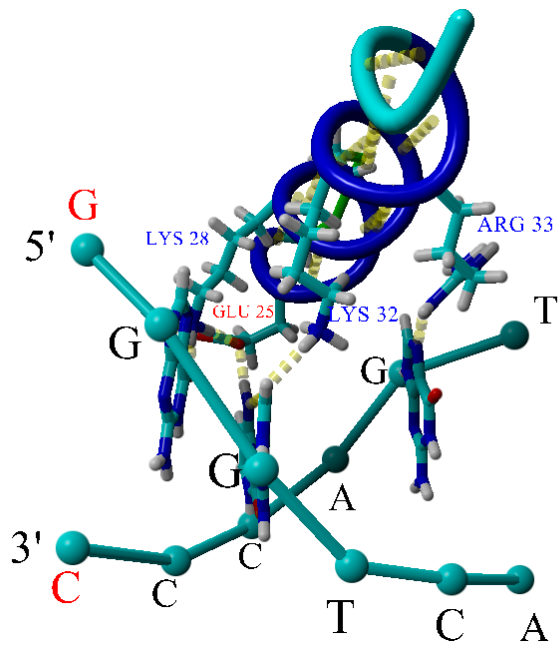

(c) GGGTCA, mutação $A \rightarrow G$ na base 1

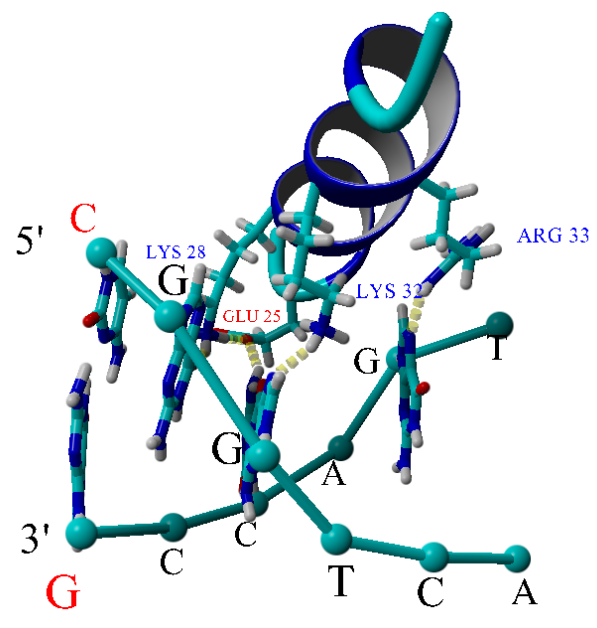

(b) CGGTCA, mutação $A \rightarrow C$ na base 1

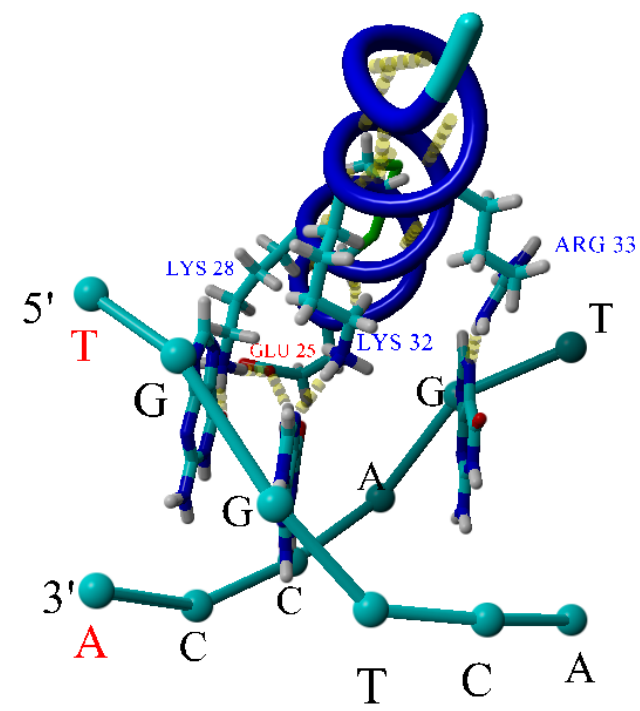

(d) TGGTCA, mutação $A \rightarrow T$ na base 1

Figura 4.35: Estruturas dos complexos positivos verdadeiros, enfatizando as ligações de hidrogênio específicas entre resíduos da hélice de ligação ao DNA e bases do TFBS. 


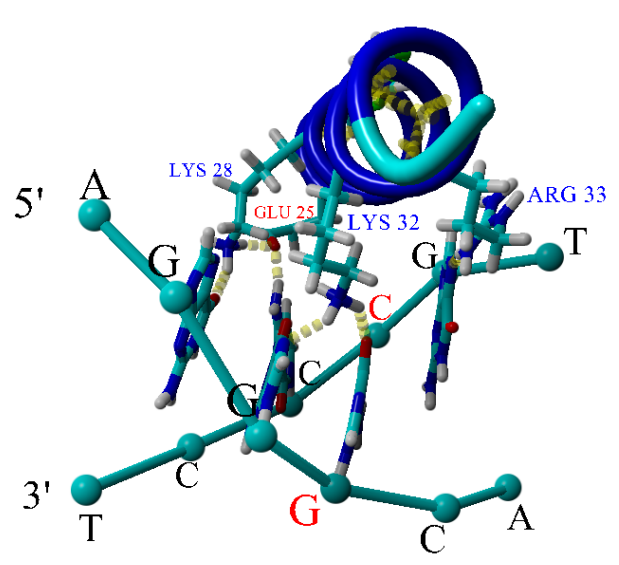

(e) AGGGCA, mutação $T \rightarrow G$ na base 4

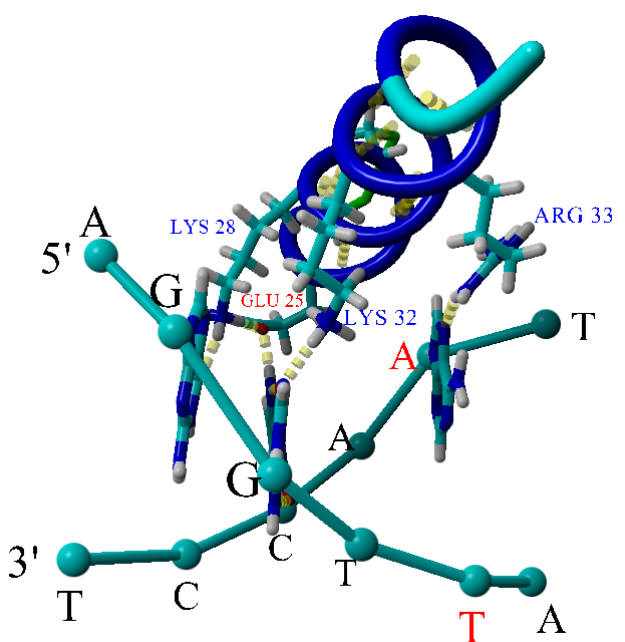

(f) AGGTTA, mutação $\mathrm{C} \rightarrow \mathrm{T}$ na base 5

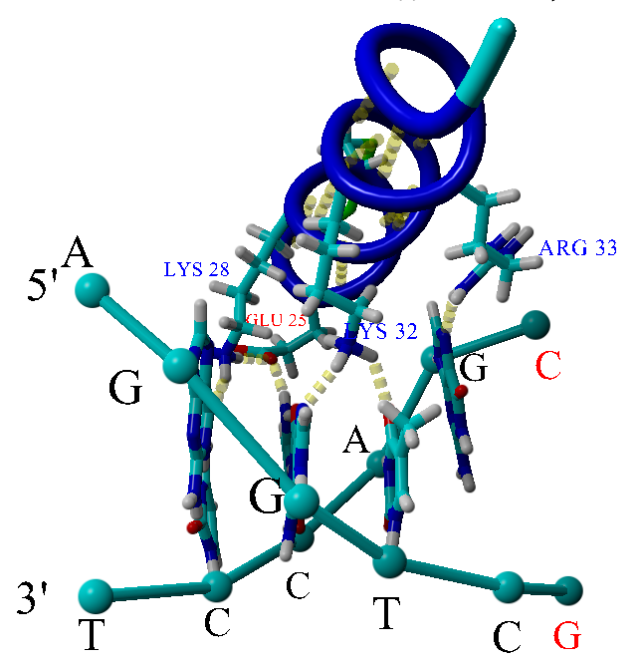

(g) AGGTCG, mutação $A \rightarrow G$ na base 6 


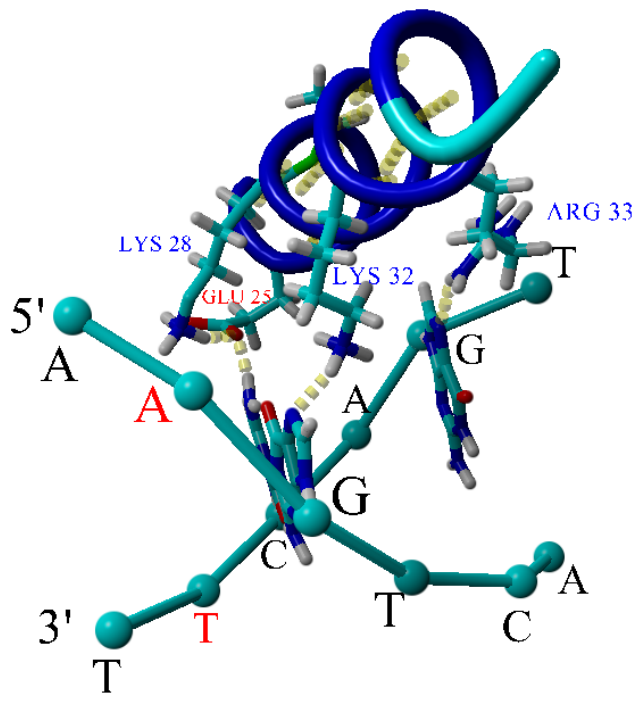

(a) AAGTCA, mutação $G \rightarrow A$ na base 2

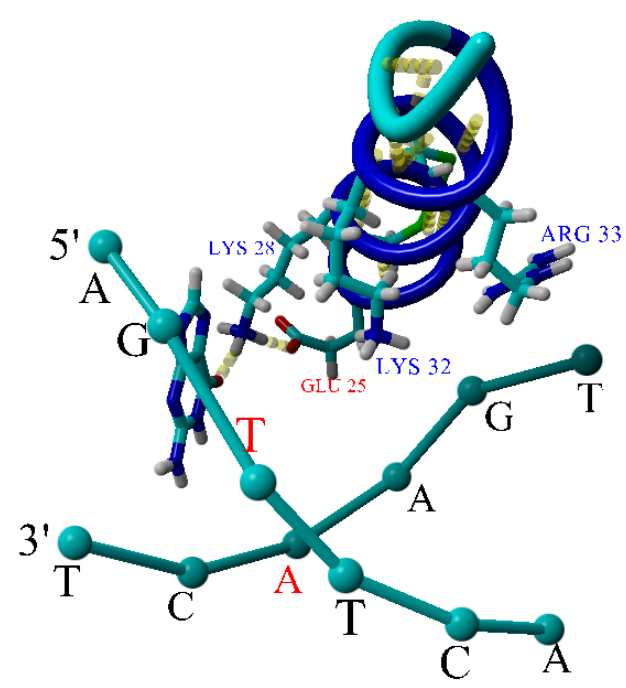

(c) AGTTCA, mutação $\mathrm{G} \rightarrow \mathrm{T}$ na base 3

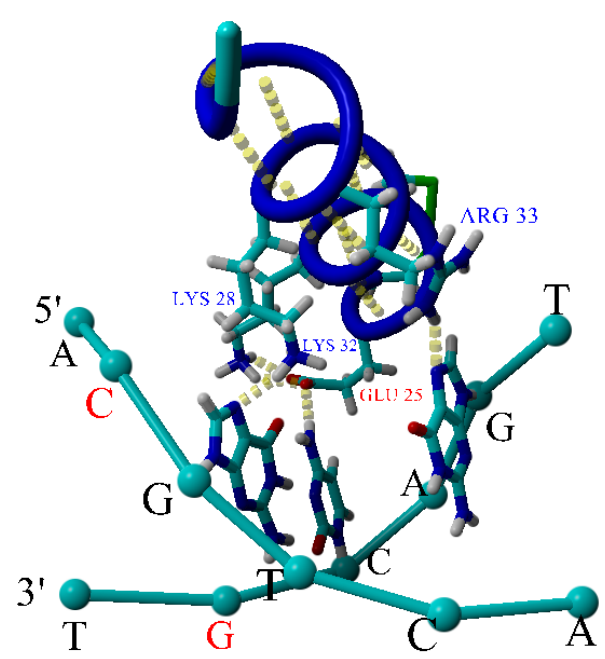

(b) ACGTCA, mutação $\mathrm{G} \rightarrow \mathrm{C}$ na base 2

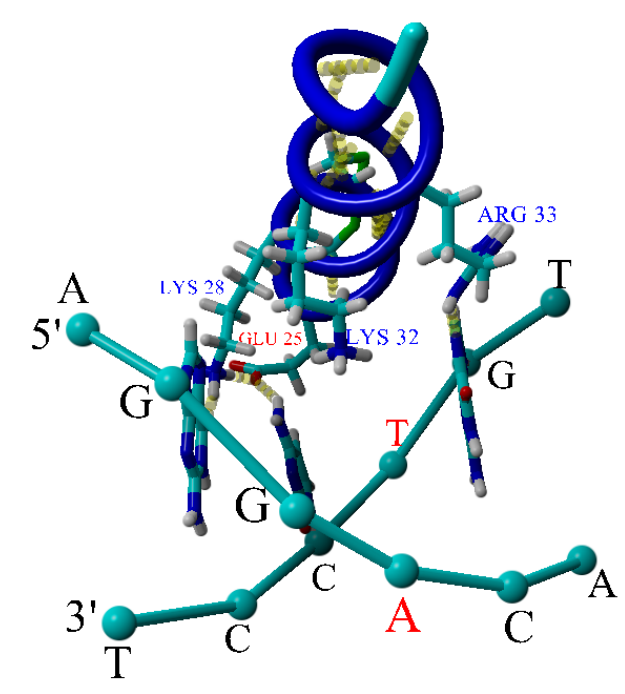

(d) AGGACA, mutação $\mathrm{T} \rightarrow \mathrm{A}$ na base 4

Figura 4.37: Estruturas dos complexos negativos verdadeiros, enfatizando as ligações de hidrogênio específicas entre resíduos da hélice de ligação ao DNA e bases do TFBS. 


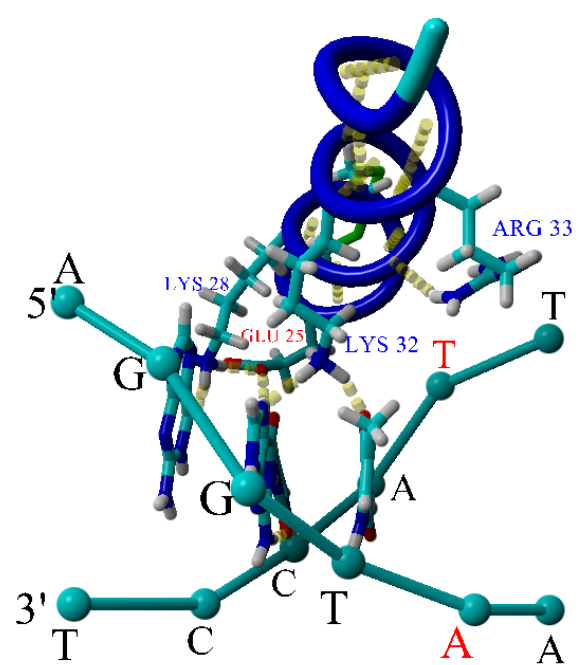

(e) AGGTAA, mutação $\mathrm{C} \rightarrow \mathrm{A}$ na base 5

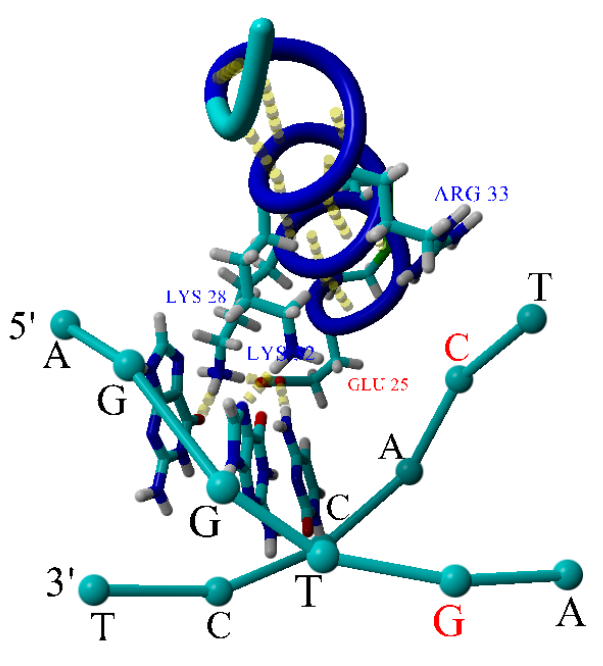

(f) AGGTGA, mutação $C \rightarrow G$ na base 5

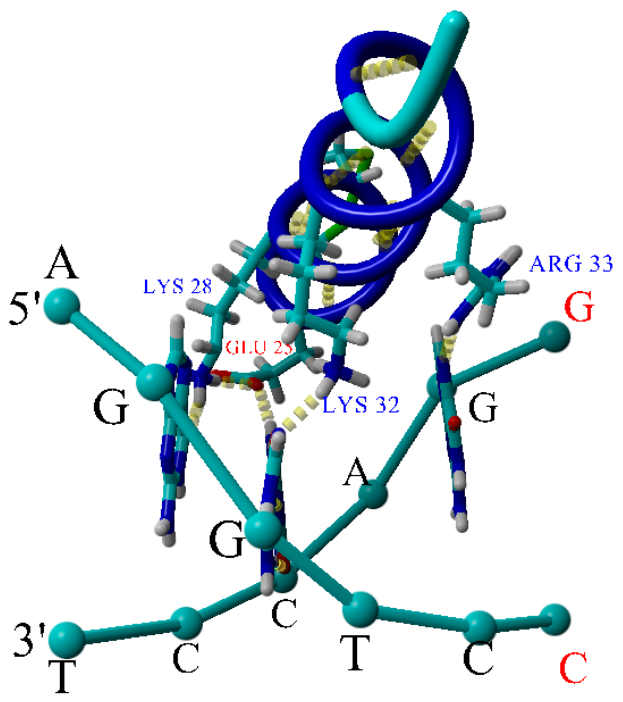

(g) AGGTCC, mutação $A \rightarrow C$ na base 6 


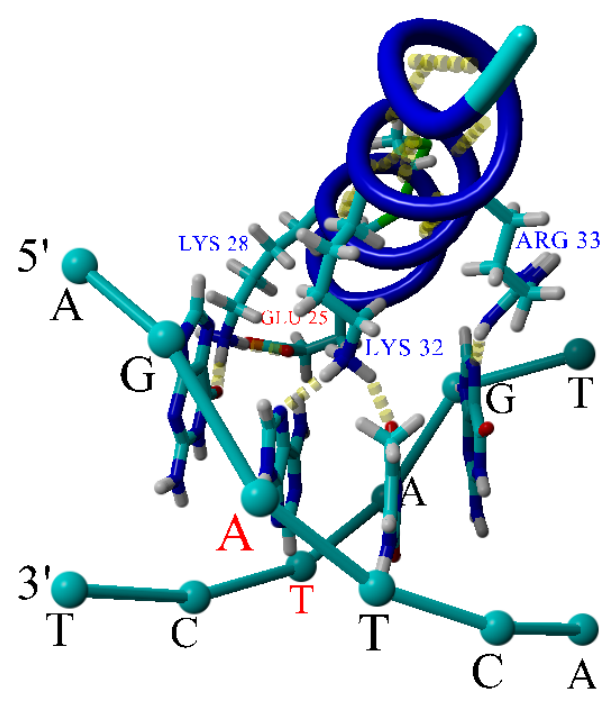

(a) AGATCA, mutação $\mathrm{G} \rightarrow \mathrm{A}$ na base 3

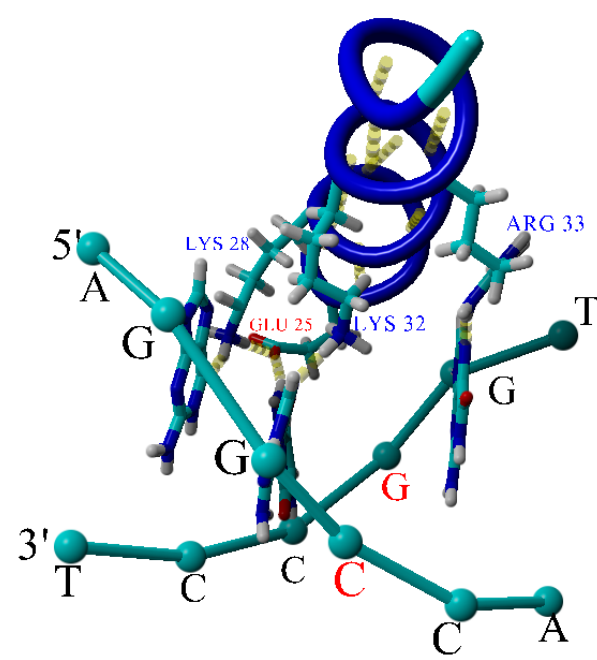

(c) AGGCCA, mutação $\mathrm{T} \rightarrow \mathrm{C}$ na base 4

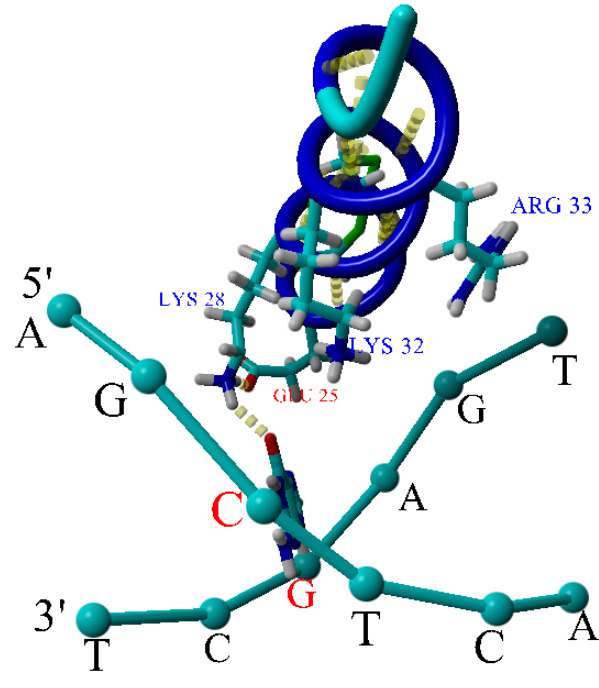

(b) AGCTCA, mutação $\mathrm{G} \rightarrow \mathrm{C}$ na base 3

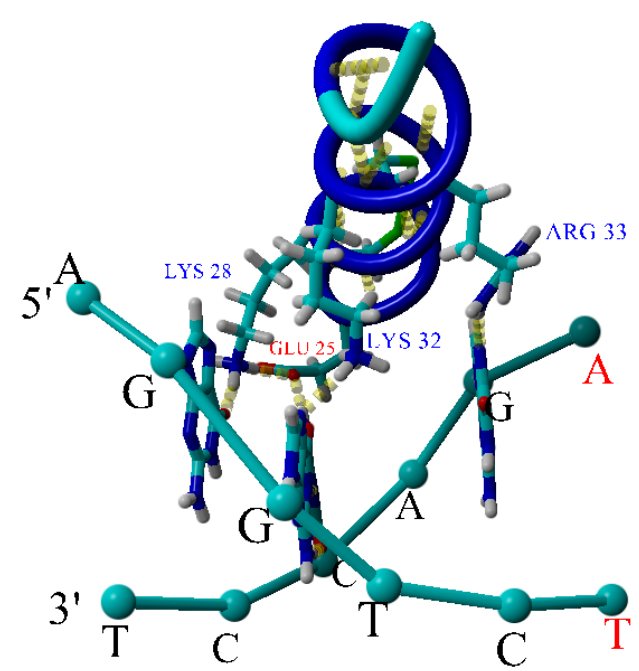

(d) AGGTCT, mutação $\mathrm{A} \rightarrow \mathrm{T}$ na base 6

Figura 4.39: Estruturas dos complexos falso-positivos, enfatizando as ligações de hidrogênio específicas entre resíduos da hélice de ligação ao DNA e bases do TFBS. 


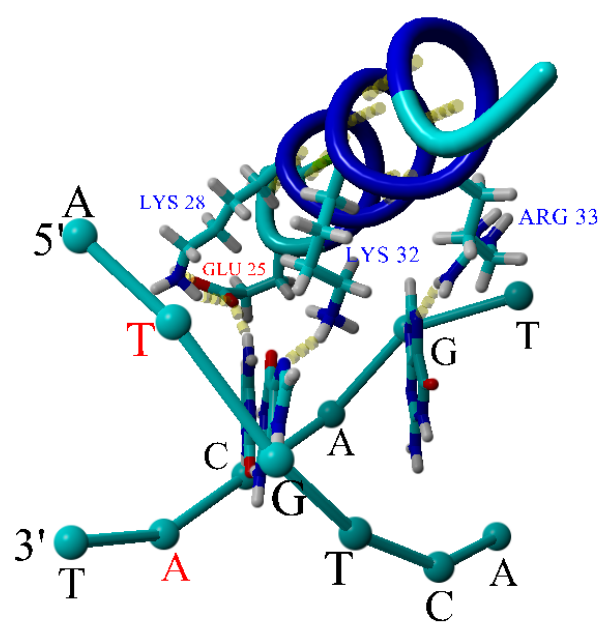

(a) ATGTCA, mutação $\mathrm{G} \rightarrow \mathrm{T}$ na base 2

Figura 4.40: Estruturas do complexo falso-negativo, enfatizando as ligações de hidrogênio específicas entre resíduos da hélice de ligação ao DNA e bases do TFBS.

Tabela 4.7: Classificação dos resultados obtidos na comparação do TFBSAnalyzer com resultados experimentais de Nguyen (Nguyen et al., 2007). Para cada uma das 6 posições existem 3 sequências possíveis após uma mutação pontual, a partir da sequência selvagem reconhecida por ER- $\alpha$. Assim, cada coluna classifica as 3 sequências em positivo verdadeiro, negativo verdadeiro, falso-positivo ou falso-negativo. A linha de Porcentagem de acertos contabiliza a porcentagem conjunta de positivos e negativos verdadeiros.

\begin{tabular}{|c|c|c|c|c|c|c|}
\cline { 2 - 7 } \multicolumn{1}{c|}{} & Base 1 & Base 2 & Base 3 & Base 4 & Base 5 & Base 6 \\
\hline Positivos Verdadeiros & 3 & 0 & 0 & 1 & 1 & 1 \\
\hline Negativos Verdadeiros & 0 & 2 & 1 & 1 & 2 & 1 \\
\hline Porcentagem de acertos & $100 \%$ & $67 \%$ & $33 \%$ & $67 \%$ & $100 \%$ & $67 \%$ \\
\hline Falso-positivos & 0 & 0 & 2 & 1 & 0 & 1 \\
\hline Falso-negativos & 0 & 1 & 0 & 0 & 0 & 0 \\
\hline
\end{tabular}

Para este experimento, o TFBSAnalyzer foi capaz de prever com mais acurácia os efeitos das mutações em bases mais externas ao TFBS, apresentando resultados menos acurados. Entretanto, o espaço amostral é bastante reduzido, portanto não é possível expandir esta conclusão para qualquer análise com o TFBSAnalyzer.

A fim de verificar a ocorrência de inconsistências, as ligações de hidrogênio entre o DNA e o ER- $\alpha$ foram analisadas, para cada um dos 19 complexos em questão, como apresentado na Figura 4.41. Destacam-se quatro resíduos cujas ligações de hidrogênio com o DNA são importantes para a especificidade da interação: Glu25, Lys28, Lys32, e Arg33. Estas ligações são as únicas que ocorrem entre resíduos do DBD e bases do DNA, enquanto todas as outras ocorrem com o esqueleto de açúcar e fosfato do DNA. Portanto, estas quatro ligações serão chamadas de ligações de hidrogênio específicas.

É interessante observar que todos os resultados positivos verdadeiros e o resultado 
falso-negativo apresentam todas as quatros ligações de hidrogênio específicas. Além disso, a maioria dos negativos verdadeiros e dos falso-positivos $(\sim 73 \%)$ carecem de pelo menos uma dessas quatro ligações. Porém, apesar de importantes para definir a especificidade da interação, estas quatro ligações não bastam para definir a ocorrência ou não da ligação, pois esta também depende da intesidade da interação entre a proteína e o DNA. Como exemplo, podemos citar o complexo AGGTCC, que apresenta as quatro ligações específicas porém possui uma energia de ligação total mais baixa do que a dos outros complexos, ou seja, uma intensidade menor, o que impossibilita a ligação proteína-DNA. A partir destas observações, seria possível criar um filtro para os resultados positivos do TFBSAnalyzer, excluindo os sítios previstos que não apresentassem todas as ligações de hidrogênio específicas. No caso do ER- $\alpha$, a aplicação deste filtro diminuiria a incidência de falso-positivos de $21 \%$ para $10,5 \%$. A implementação deste filtro depende da definição, preferencialmente automática, das ligações de hidrogênio específicas da interação. Uma possibilidade seria analisar a distribuição de ligações de hidrogênio entre as bases e a hélice de ligação nos complexos com maior escore de ligação, verificando e anotando todas as ligações de hidrogênio específicas encontradas. Isto pode ser feito de forma automática e rápida, após o cálculo de distribuição de energia de ligação para o TF em estudo.

A fim de analisar melhor a influência das ligações de hidrogênio entre o DBD de ER$\alpha$ e o DNA, foram calculadas as distribuições de quantidade e energia das ligações de hidrogênio, tanto inespecíficas (entre DBD e DNA em geral) quanto específicas (entre hélice de ligação ao DNA e bases nitrogenadas). Os resultados estão apresentados na Figura 4.42 .

Considerando os dados mostrados na Figura 4.41, a variação máxima de energia dos complexos positivos verdadeiros para os complexos negativos verdadeiros foi de $\approx 381,7 \mathrm{~kJ} / \mathrm{mol}$ (entre AGGGCA e ACGTCA), e a mínima de $\approx 104 \mathrm{~kJ} / \mathrm{mol}$ (entre AGGTTA e AGGACA). Em ambos os casos a diferença entre as duas sequências é de duas bases. Estes valores são da ordem da variação máxima de energia de ligações de hidrogênio observada nas Figuras 4.42b e 4.42d. Entretanto, pequenas alterações da energia referente às ligações de hidrogênio podem não ser percebidas através apenas da energia de ligação. Para verificar a relação destas duas grandezas, calculou-se a correlação de Pearson entre a distribuição de energia de ligação e as duas distribuições de energia de ligações de hidrogênio (específicas e inespecíficas). No caso das ligações de hidrogênio inespecíficas, obteve-se uma correlação de $\approx 0,6873$, e no caso das específicas de $\approx 0,6487$. Como a correlação não foi 1 , acrescentar esta variável no cálculo do escore de ligação não seria redundante e, portanto, poderia melhorar a especificidade do TFBSAnalyzer. 


\begin{tabular}{|c|c|c|c|c|c|c|c|c|c|c|c|c|c|c|c|c|}
\hline & \multirow{2}{*}{ Complexo } & \multirow{2}{*}{$\begin{array}{c}\text { Energia de } \\
\text { Ligaçāo } \\
(\mathrm{kJ} / \mathrm{mol})\end{array}$} & \multicolumn{2}{|c|}{$\begin{array}{c}\mathrm{DNA}+\mathrm{DBD}+ \\
\text { água }\end{array}$} & \multicolumn{2}{|c|}{$D N A+D B D$} & \multicolumn{2}{|c|}{ DNA + Hélice } & \multicolumn{2}{|c|}{$\begin{array}{c}\text { HBo Glu25 + } \\
\text { DNA }\end{array}$} & \multicolumn{2}{|c|}{$\begin{array}{c}\text { HBo Lys28 + } \\
\text { DNA }\end{array}$} & \multicolumn{2}{|c|}{$\begin{array}{c}\text { HBo Lys32 + } \\
\text { DNA }\end{array}$} & \multicolumn{2}{|c|}{$\begin{array}{c}\text { HBo Arg33 + } \\
\text { DNA }\end{array}$} \\
\hline & & & \#HBo & $\begin{array}{l}\text { Energia } \\
(\mathrm{kJ} / \mathrm{Mol})\end{array}$ & \#HBo & $\begin{array}{l}\text { Energia } \\
(\mathrm{kJ} / \mathrm{Mol})\end{array}$ & \#HBo & $\begin{array}{l}\text { Energia } \\
(\mathrm{kJ} / \mathrm{Mol})\end{array}$ & \#HBO & $\begin{array}{l}\begin{array}{l}\text { Energia } \\
(\mathrm{kJ} / \mathrm{Mol})\end{array} \\
\end{array}$ & \#HBo & $\begin{array}{r}\begin{array}{r}\text { Energia } \\
(\mathrm{kJ} / \mathrm{Mol})\end{array} \\
\end{array}$ & \#HBo & \begin{tabular}{|l}
$\begin{array}{l}\text { Energia } \\
(\mathrm{kJ} / \mathrm{Mol})\end{array}$ \\
\end{tabular} & \#HBO & $\begin{array}{l}\begin{array}{l}\text { Energia } \\
(\mathrm{kJ} / \mathrm{Mol})\end{array} \\
\end{array}$ \\
\hline \multirow{7}{*}{ PV } & AGGTCA (wt) & 5675,00 & 5922 & 138987,55 & 12 & 248,45 & 4 & 74,55 & 1 & 25,00 & 1 & 17,60 & 1 & 8,10 & 1 & 23,85 \\
\hline & CGGTCA & 565 & 5984 & 140385,58 & 13 & 265,70 & 4 & 8,58 & 1 & 18,58 & 1 & & 1 & 21,50 & 1 & 11,50 \\
\hline & GGGTCA & & 5948 & 39756,03 & & & 4 & & 1 & 5,00 & 1 & & 1 &, 20 & 1 & 22,28 \\
\hline & TGGTCA & 5720,28 & 5951 & 139750,55 & 13 & 282,90 & 4 & & 1 & 20,73 & 1 & 23,45 & 1 & 25,00 & 1 & 25,00 \\
\hline & AGGGCA & 5730 & 5938 & 139767,10 & 14 & 287,63 & 4 & 1,10 & 1 & 25,00 & 1 & 16,63 & 1 & 14,48 & 1 & 25,00 \\
\hline & AGGTTA & 5648,19 & 5974 & 140467,93 & 13 & 279,35 & 4 & 91,35 & 1 & 25,00 & 1 & 22,88 & 1 & 24,43 & 1 & 19,05 \\
\hline & AGGTCG & 5712 , & 5945 & 139819,58 & 14 & 284,55 & 4 & 77,38 & 1 & 25,00 & 1 & 20,73 & 1 & 12,50 & 1 & 19,15 \\
\hline \multirow{7}{*}{ NV } & & & 5935 & 3,05 & & & 3 & & 1 & 25,00 & ( & & 1 & 21,10 & 1 & 13,55 \\
\hline & ACG & 534 & 5958 & 140068,25 & 12 & 246,18 & 3 & & 1 & 23,85 & & 0 & 1 & 21,88 & 1 & 13,90 \\
\hline & AGTTCA & 539 & 5941 & 140122,53 & 9 & 192,90 & 1 &, 00 & 0 & 00 & 1 & 25,00 & & 0,00 & 0 & 0,00 \\
\hline & AGGACA & 5544,13 & 5946 & 139900,20 & 12 & 256,75 & 3 & 0 & 1 & 17,78 & 1 & 1,50 & 0 &, 00 & 1 & 20,33 \\
\hline & AGG & 544 & 5923 & 139302,53 & 1 & 257,38 & & & & 25,00 & 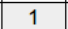 &, 73 & 1 & 3,75 & 0 & 0,00 \\
\hline & AGG & 5510,24 & 5937 & 39891,00 & & 270,18 & 8 & & 1 & 25,00 & 1 & 25,00 & 1 & 25,00 & 0 & 0,00 \\
\hline & AGGTCC & 5499,92 & 5961 & 40133,65 & 13 & 263,40 & 4 & 9,90 & 1 & 25,00 & 1 & 19,55 & 1 & 21,50 & 1 & 23,85 \\
\hline \multirow{4}{*}{ FP } & AGATCA & 5653,83 & 5986 & 40579,83 & 13 & 273,78 & 3 & 64,10 & 0 & 0,00 & 1 & 22,28 & 1 & 19,55 & 1 & 22,28 \\
\hline & AGCTCA & 5640,37 & 5954 & 139977,40 & 10 & 197,55 & 1 & 17,78 & 0 & 0,00 & 1 & 17,78 & 0 & 0,00 & 0 & 0,00 \\
\hline & AGGCCA & 5744,24 & 5931 & 139437,05 & 13 & 276,68 & 4 & 86,20 & 1 & 16,28 & 1 & 19,93 & 1 & 25,00 & 1 & 25,00 \\
\hline & AGGTCT & 5708,96 & 5928 & 139148,70 & 14 & 286,18 & 4 & 77,68 & 1 & 25,00 & 1 & 23,85 & 1 & 6,55 & 1 & 22,28 \\
\hline $\mathrm{FN}$ & ATGTCA & 5538,50 & 5959 & 140016,75 & 12 & 247,03 & 3 & 60,43 & 1 & 24,43 & 0 & 0,00 & 1 & 17,50 & 1 & 18,50 \\
\hline
\end{tabular}

Figura 4.41: Contagem das ligações de hidrogênio em cada complexo DNA-ER- $\alpha$ analisado. A tabela também mostra a energia de ligação calculada para cada complexo. As ligações de hidrogênio foram contabilizadas de quatro maneiras diferentes:

- DNA + DBD + água: todas as ligações de hidrogênio no complexo neutralizado, inclusive as ligações entre moléculas de água.

- DNA + DBD: ligações entre o DNA e o DBD do ER- $\alpha$.

- DNA + Hélice: ligações entre o DNA e a hélice de ligação ao DNA do ER- $\alpha$, considerando apenas as ligações específicas, isto é, aquelas que ocorrer entre um resíduo e uma base nitrogenada, excluindo ligações de hidrogênio com o esqueleto de açúcar e fosfato.

- Hbo X + DNA: ligações específicas entre o resíduo X (Glu25, Lys 28, Lys 32 ou Arg33) e o DNA. Estas são as quatro ligações principais para a determinação da especificidade da interação ER- $\alpha$ DNA.

Os complexos são classificados em Positivos Verdadeiros (PV), Negativos Verdadeiros (NV), Falso-positivos (FP) e Falso-negativo (FN). 


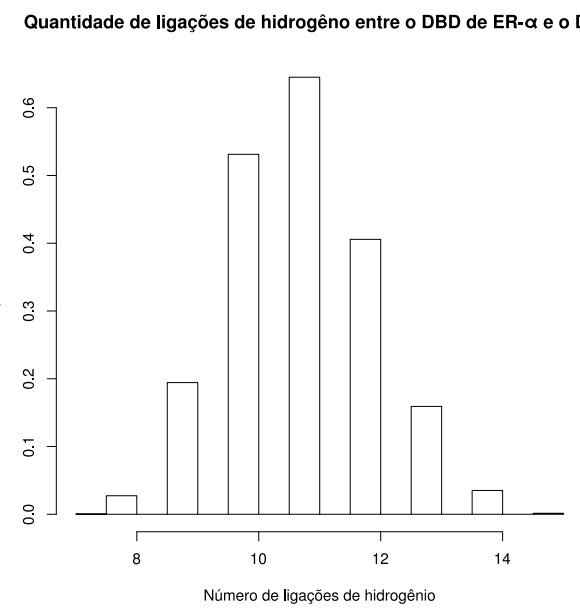

(a)

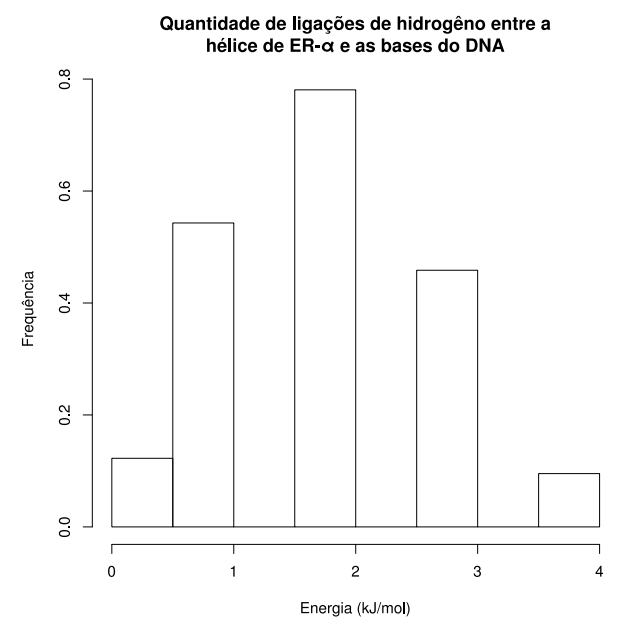

(c)
Energia das ligações de hidrogêno entre o DBD de ER- $\alpha$ e o DNA

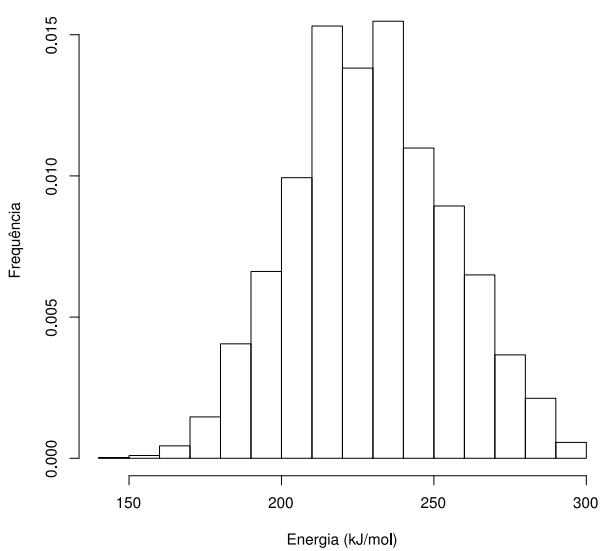

(b)

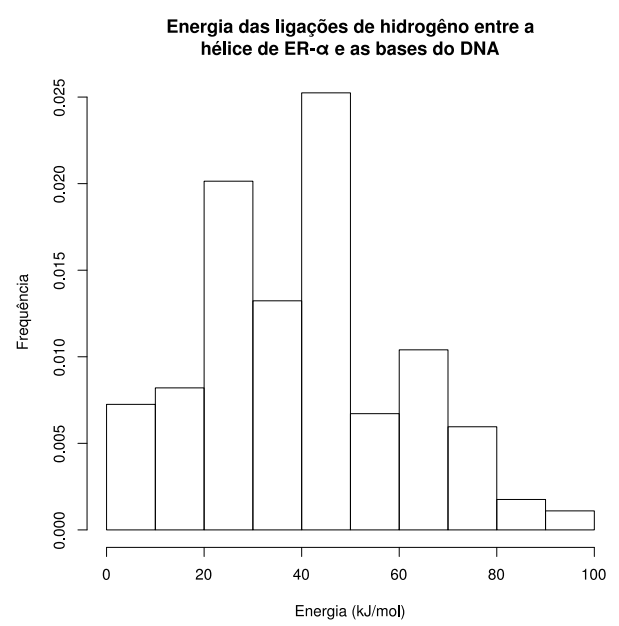

(d)

Figura 4.42: Distribuição da quantidade (a) e da energia (b) das ligações de hidrogênio entre o DBD e o DNA nos complexos ER- $\alpha$-DNA. Distribuição da quantidade (c) e da energia (d) das ligações de hidrogênio entre as bases do DNA e a hélice de ligação ao DNA nos complexos ER- $\alpha$-DNA. 


\section{Capítulo 5}

\section{Discussão}

\subsection{Complexação de TFs com DNA in vivo e expressão gênica}

Existem diversos fatores que devem ser considerados ao realizar predições de TFBSs in vivo, especialmente no caso de eucariotos, os quais são capazes de gerar diversos padrões de expressão a partir de um conjunto pequeno de regiões regulatórias, empregando diversas estratégias (Levine and Tjian, 2003). Uma destas estratégias é o controle da acessibilidade ao DNA, através da formação de nucleossomos em regiões específicas, inibindo a complexação por impedimento estérico. Modificações como metilação de DNA e acetilação/fosforilação de histonas são altamente reguladas e são cruciais para a transcrição, pois delas decorrem a remodelagem da cromatina e a expulsão das histonas, deixando a estrutura do DNA acessível para a complexação de TFs e iniciação da transcrição (Li et al., 2007). A estratégia de coregulação entre diversos TFs, muitas vezes sinergística, também aumenta a complexidade da análise de seus efeitos na transcrição, uma vez que não é possível simplesmente somar os efeitos observados para os TFs isoladamente (Weingarten-Gabbay and Segal, 2014). Também existem mecanismos de competição entre TFs pela ligação com o DNA (Spitz and Furlong, 2012) e mecanismos de silenciamento de grandes domínios de DNA, tornando-os inacessíveis a TFs e outras proteínas de ligação ao DNA (Moazed, 2001). Outro fator não tratado por métodos computacionais preditivos é o ângulo relativo entre o TFBS e o TSS devido à estrutura de dupla hélice do DNA. A orientação do TF em relação ao TSS depende da distância em que está localizado seu TFBS, pois a cada $\approx 10,5$ nucleotídeos a hélice dá uma volta completa. (Nelson and Cox, 2005). Portanto, o espaçador entre o TSS e o TFBS pode gerar padrões de expressão diferentes, como observado por (Yu et al., 1997). Dado que a transcrição é um fenômeno direcional, a orientação do sítio em relação ao TSS também pode afetar a ativação da transcrição, uma vez que este fenômeno é unidirecional, pois se o TF se liga normalmente na mesma fita em que está o gene, ao ligar-se em um sítio na fita complementar pode deixá-lo em uma posição no 
espaço desfavorável para o recrutamento de outros fatores. (Weingarten-Gabbay and Segal, 2014).

Em suma, a simples presença de um potencial TFBS no promotor de um gene não implica em ativação ou inibição do mesmo. Portanto, é importante ressaltar que o TFBSAnalyzer é uma ferramenta para encontrar possíveis TFBSs para um determinado $\mathrm{TF}$, cujos resultados devem ser analisados para contextualização biológica. Considerando seu propósito, o desempenho do TFBSAnalyzer é satisfatório, pois é comparável ao desempenho do TRANSFAC, um software comercial, para a análise de sequências pequenas, mas tem a vantagem de ser praticamente independente de experimentos, os quais tendem a ser demorados e custosos. Entretanto, seria interessante melhorar ainda mais o desempenho deste novo método, para torná-lo mais confiável. A seção seguinte apresenta algumas possibilidades para aumentar a acurácia do TFBSAnalyzer.

\subsection{Uso de outros fatores no cálculo do escore de ligação}

Apesar de o método ter apresentado resultados bastante satisfatórios, houve uma taxa considerável de falso-positivos na comparação com resultados experimentais, especialmente para o ER- $\alpha$. O emprego de mais fatores no cálculo do escore de ligação poderia aumentar a acurácia do método. Portanto, uma análise termodinâmica mais aprofundada faz-se necessária para identificar as possíveis origens destes erros. As seções a seguir apresentam as estratégias que poderiam ser utilizadas para tentar corrigir os resultados incorretos, com ênfase nos resultados falso-positivos para o ER- $\alpha$.

\subsubsection{Inclusão da entropia na classificação dos complexos}

A formação de um complexo proteína-DNA pode ser analisada como uma reação química binária, do tipo $\mathrm{A}+\mathrm{B} \rightarrow \mathrm{C}$. Portanto, a ocorrência ou não deste processo é dependente da energia livre envolvida, Em seu trabalho, Jen-Jacobson e colaboradores (Jen-Jacobson et al., 2000) mostram o efeito da compensação entalpia-entropia na interação entre 10 TFs e seus TFBSs, no qual a variação de entropia $(\Delta S)$ e a variação de entalpia $(\Delta H)$ compensam-se mutuamente e levam a uma variação de energia livre favorável negativa. Para algumas proteínas, $\mathrm{o} \Delta \mathrm{H}$ da complexação é positivo, porém um $\Delta S$ bastante positivo, compensando assim o $\Delta H$ desfavorável e alcançando uma variação de energia livre de ligação negativa. Para outras proteínas, o $\Delta S$ era negativo, mas o $\Delta \mathrm{H}$ também é bastante negativo, compensando o $\Delta \mathrm{S}$ desfavorável. Outras proteínas enquadram-se em casos intermediários, com $\Delta \mathrm{H}$ e $\Delta \mathrm{S}$ favoráveis em menor proporção. A Figura 5.1 mostra o resultado obtido por Jen-Jacobson e colaboradores. A contribuição entrópica positiva (desfavorável) é principalmente atribuída a distorções causadas na estrutura do DNA durante a formação do complexo.

Considerando a estrutura dos complexos entre DNA e NRs, o repressor cI do bacteriófago $\lambda$ seria o exemplo mais próximo. Ao utilizar apenas a entalpia do sistema, 


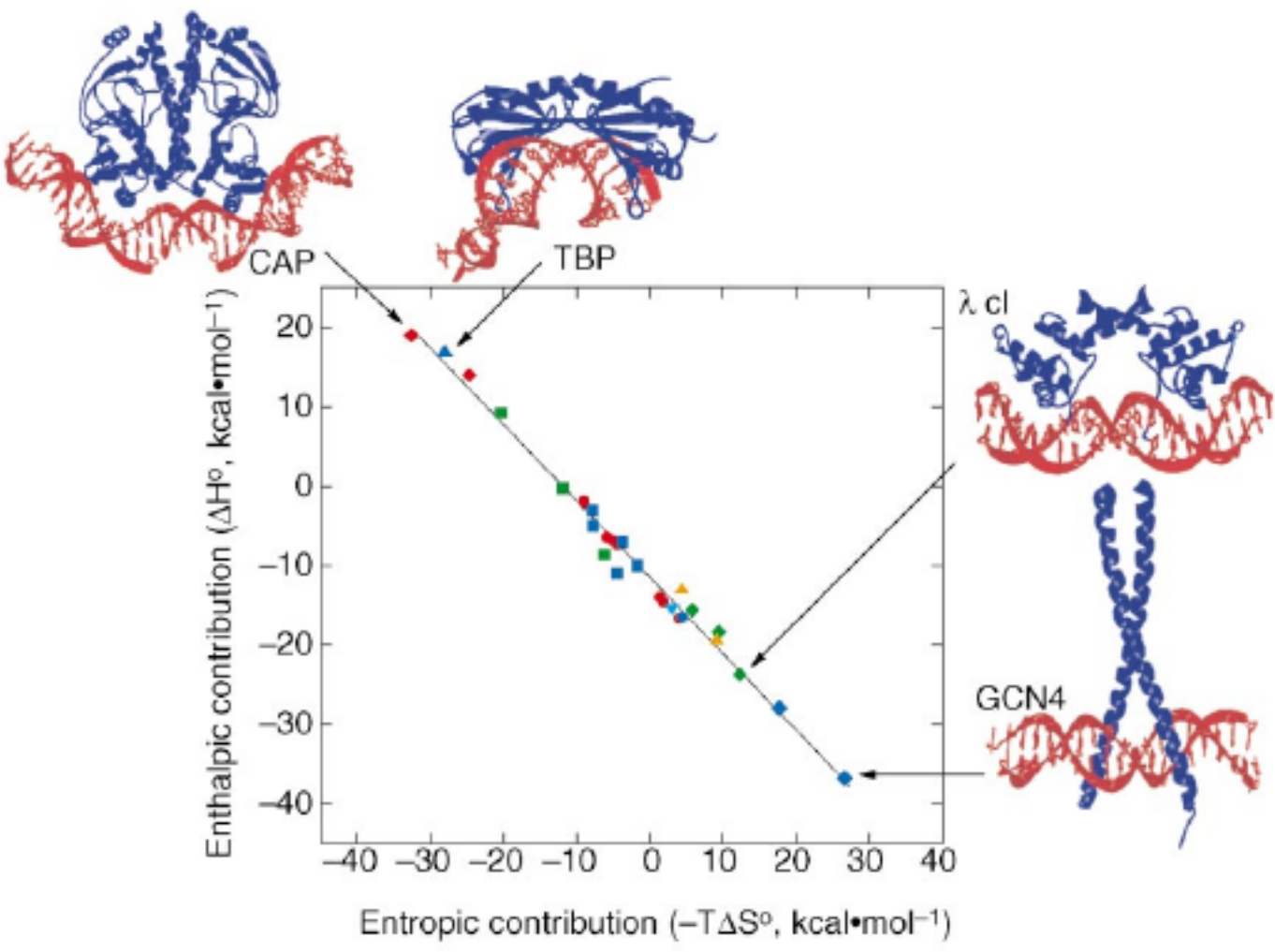

Figura 5.1: Contribuições entálpicas $(\Delta \mathrm{H})$ e entrópicas $(\Delta \mathrm{S})$ para a energia livre de ligação, a 298K, para complexos de reconhecimento específico formados por proteínas ligantes ao DNA, de reconhecimento de sítios especificos. Diamantes vermelhos: CAP ligada ao uma sequência consenso e ao promotor lac de $\mathrm{E}$. coli; Triângulo azul: proteína ligante a sítios TATA; Quadrados verdes: endonuclease EcoRI ligada ao sítio GAATTC incorporado em três contextos diferentes de flanqueamento; Círculos vermelhos: endonuclease BamHI ligada ao sítio GGATCC incorporado em sete contextos diferentes de flanqueamento; Quadrados azuis: Repressor Lac ligado ao operador lac simetrizado e quatro variantes com substituições simples ou duplas; Triângulo invertido azul claor: myb; Círculo azul: repressor trp; Triângulos laranjas: homeodomínio mat2; Diamantes verdes: repressor cI do bacteriófago $\lambda$ ligado aos sítios OR1, OR2, ou OR3; Diamantes azuis: ativador transcricional GCN4-bZIP. Quando possível, os dados foram levados a um $\mathrm{pH}$ de 7,4 e para as concentrações de sal na gama de 0,1-0,2 M. Figura extraída de (Jen-Jacobson et al. 2000).

o TFBSAnalyzer assume que a formação in vivo da maioria dos complexos com NRs tenha uma contribuição de $\Delta H$ mais importante do que de $\Delta S$. Porém, podem existir sequências cujos complexos apresentem um $\Delta S$ positivo mais significativo do que o $\Delta \mathrm{H}$ positivo, levando a uma energia livre de ligação negativa (favorável). Como a heurística implementada em TFBSAnalyzer não utiliza informações entrópicas dos complexos para a aceleração dos cálculos, estes casos resultariam em falso-positivos. Ao mesmo tempo que considerar apenas componentes entálpicas para classificar as sequências-problema foram bem sucedidas, em algumas situações levaram à geração 
de falso-positivos, como pode ser o caso observado nas análises com ER- $\alpha$. Portanto, a consideração de variáveis entrópicas para o cálculo do escore de ligação seriam interessantes para tentar melhorar a especificidade do método.

Ainda não é possível calcular a contribuição de $\Delta S$ ) para a energia livre. Porém, é possível calcular a variação da energia de solvatação devido à formação do complexo. Além das contribuições de energia coulômbicas e de Van der Waals, este cálculo leva em consideração o custo entrópico da exposição da área de interação da proteína e do DNA, antes coberta por moléculas de água. Este custo deve-se à necessidade de reorganização das moléculas de água. Alguns testes iniciais foram desenvolvidos, porém ainda é necessário realizar mais pesquisas para definir a melhor maneira de incluir este fator no escore de ligação.

\subsubsection{Inclusão da energia de ligações de hidrogênio na classificação dos complexos}

Como apontado na seção 4.9, seria possível calcular de forma automática e rápida a energia proveniente das ligações de hidrogênio formadas entre os principais resíduos da hélice de ligação ao DNA e as bases nitrogenadas do TFBS. Dado que a correlação encontrada entre a energia de ligação e a energia de ligações de hidrogênio não foi de $100 \%$, é possível que ao acrescentar esta informação na classificação dos complexos o desempenho do TFBSAnalyzer seja melhorado. É necessário um estudo mais aprofundado para incluir corretamente este fator no cálculo do escore de ligação. Também seria necessário decidir como tratar fatores de transcrição cujos resíduos mais importantes para a interação com o DNA ainda não são conhecidos. Uma possibilidade seria permitir ao usuário do programa informar quais são estes resíduos ou realizar algum tipo de inferência.

\subsection{Desvantagens do algoritmo proposto}

Para ser executado, o algoritmo depende da disponibilidade da estrutura do fator de transcrição de interesse. Porém, existem diversas estruturas de fatores de transcrição disponíveis em bancos de dados como o PDB, além de vários métodos de modelagem para predizer a estrutura de proteínas, cada vez mais rápidos e acurados. No caso dos NRs, a grande similaridade entre seus DBDs e a disponibilidade da estrutura de pelo menos alguns deles permite o emprego da modelagem por homologia, resultando em estruturas com alta confiabilidade. Outra desvantagem reside no fato de o tempo de execução e a memória utilizada pelo programa crescerem exponencialmente com o tamanho do TFBS de interesse. Porém, com o avanço rápido da tecnologia tanto de processadores quanto de memória, este problema torna-se cada vez menos importante. Ao comparar os resultados obtidos para o heterodímero RAR- $\beta$-RXR com aqueles obtidos para o dímero de ER- $\alpha$, observa-se que, aparentemente, o algoritmo não é tão 
sensível a mutações pontuais quanto a mutações em mais de um nucleotídeo vizinho. Isso poderia estar associado ao fato de o algoritmo não considerar a variação de entropia derivada da complexação do fator de transcrição com o DNA. A tentativa de incluir a energia de solvatação como parcela de entropia no cálculo do escore de ligação não foi bem sucedida, apesar de ainda ser possível analisar novamente as componentes entálpicas e entrópicas e verificar uma maneira mais correta de unificá-las em um único escore. Além disso, seria possível utilizar outros fatores para tentar melhorar a acurácia do TFBSAnalyzer, como a energia de ligações de hidrogênio específicas entre o TF e o DNA.

\subsection{Vantagens do algoritmo proposto}

Ao contrário da grande maioria dos métodos disponíveis de predição de TFBSs, nosso algoritmo não depende de experimentos caros, laboriosos e demorados. O algoritmo proposto por Alamanova e colaboradores também não depende deste tipo de experimentos, porém utiliza a informação de apenas $4 * \mathrm{~N}$ complexos, enquanto nosso algoritmo utiliza a informação de $4^{N}$ complexos, sendo portanto mais confiável. Adicionalmente, nosso algoritmo também não depende da construção de PWMs, como ocorre com praticamente todos os métodos de predição de TFBSs disponíveis. Ao utilizar a energia de ligação como base para o cálculo do escore, as informações sobre a interação entre os nucleotídeos vizinhos em um TFBS, perdidas na construção de PWMs, são consideradas por nosso algoritmo, o que torna as predições mais confiáveis. O algoritmo pode ser aplicado, em princípio, para qualquer tipo de fator de transcrição, e os resultados com o receptor de C. elegans reforçam a possibilidade de aplicação a fatores de seres vivos além de humanos. Adicionalmente, experimentos de mutação de resíduos específicos em fatores de transcrição para avaliar os efeitos nos TFBSs reconhecidos podem ser facilmente implementados. O programa que implementa o TFBSAnalyzer é bastante simples de ser utilizado e, por ser paralelizado, pode ser executado com alta velocidade, calculando uma distribuição inteira em aproximadamente $12 \mathrm{~h}$ em um notebook pessoal. Uma vez obtida a distribuição de energia para um fator de transcrição, a varredura de sequências de DNA utilizando a ferramenta de varredura do TFBSAnalyzer é praticamente imediata, e bastante rápida para sequências da ordem de magnitude do genoma humano (5 minutos em um notebook pessoal). Portanto experimentos de mutação de sequências de DNA e análise de seus efeitos no reconhecimento de TFBSs podem ser realizados muito facilmente. 


\subsection{Perspectivas}

\subsubsection{Uso de outros fatores no cálculo do escore de energia}

A fim de aperfeiçoar o TFBSAnalyzer, deve-se realizar um estudo mais aprofundado de outros fatores que possam ser incluídos no cálculo do escore de energia, principalmente para diminuir a taxa de falso-positivos obtida. Alguns estudos já foram iniciados neste trabalho, como o de energia de solvatação e energia de ligações de hidrogênio, entretanto estes mesmos podem ser mais aprofundados e novos fatores podem ser sugeridos.

\subsubsection{Aplicação para TFs de outras famílias estruturais}

O TFBSAnalyzer pode ser aplicado facilmente para qualquer tipo de fator de transcrição. Dado que seu desempenho já foi testado com TFs do tipo dedo de zinco, o próximo passo seria verificar o funcionamento do método com TFs de outras famílias estruturais e utilizar dados experimentais para validação, de maneira semelhante à que foi feita neste trabalho.

\subsubsection{Competição entre NRs por um mesmo TFBS}

A classificação feita pelo TFBSAnalyzer considera os dados de uma forma qualitativa, porém há indícios de que seria possível realizar análises quantitativas com esta ferramenta. Uma questão interessante de ser analisada é a competição entre os NRs analisados neste trabalho por sítios com alto escore de ligação para todos. Como foi observado, as faixas de energia de ligação destes NRs são bastante diferentes e sabese que as sequências reconhecidas por estes TFs são bastante semelhantes. Portanto seria interessante realizar um experimento de bancada para verificar se os TFs com maior energia de ligação predita pelo TFBSAnalyzer também apresentam um melhor desempenho em uma competição por um TFBS, in vivo e in vitro. 


\section{Capítulo 6}

\section{Conclusões}

O algoritmo proposto foi capaz de predizer corretamente os TFBSs existentes nos promotores $\operatorname{RAR} \beta 2$ (para o heterodímero RAR- $\beta$-RXR) e vitERE (para o dímero de ER$\alpha$ ). Os resultados do experimento de análise de expressão induzida pela interação de $\operatorname{RAR} \beta$-RXR com sequências mutantes do RARE $\beta$ foram previstos com $89 \%$ de acertos para um valor de corte entre 0,77 e 0,86 . Nesta mesma faixa, foi obtida uma taxa de positivos reais de $100 \%$ e uma taxa de falso-positivos de $25 \%$. No caso do experimento de análise de complexação entre ER- $\alpha$ e sequências mutantes do TFBS contido no promotor vitERE, o algoritmo foi capaz de predizer corretamente $72 \%$ dos resultados, para um valor de corte entre 0,85 e 0,91. Nesta mesma faixa, foi obtida uma taxa de positivos reais de $86 \%$ e uma taxa de falso-positivos de $36 \%$ (ou $27 \%$ para valor de corte 0,91 ). Também é possível variar o valor de corte para faixas mais baixas ou mais altas, de acordo com a intensidade da interação entre os TFBSs de interesse com o fator de transcrição, ou seja, para encontrar TFBSs cuja interação com a proteína sejam um pouco mais fracos, podem-se utilizar valores de corte mais baixos.

Foram desenvolvidos dois programas para executar o TFBSAnalyzer: um que calcula a distribuição de energia de ligação para um TF, tendo como entrada um arquivo PDB descrevendo a estrutura do complexo deste TF com o DNA; e outro que utiliza a distribuição calculada pelo primeiro para fazer varreduras em sequências de DNA fornecidas como arquivos (multi)fasta. O primeiro programa foi paralelizado, permitindo ao usuário escolher quantas threads deseja executar ao mesmo tempo, sendo que as tarefas são divididas igualmente entre elas. Ambos os programas são capazes de retomar um trabalho interrompido por qualquer motivo, evitando a perda de tempo devido a falhas de energia ou outros motivos.

Com o desenvolvimento destes programas, foi possível realizar uma varredura com um dímero de ER- $\alpha$ no genoma humano, simulando um experimento virtual de ChIPSeq. Estes genes foram filtrados considerando a distribuição de TFBSs próximos ao TSS, onde observa-se in vivo uma densidade maior de TFBSs. Este filtro foi aplicado de maneira bastante estringente e selecionou apenas 195 genes, dos quais 18 têm a 
transcrição comprovadamente regulada por ER- $\alpha$. Eventos falso-positivos podem ser causados por diversas simplificações, desde os cálculos das energias até a aplicação da varredura desconsiderando outros fatores na regulação da transcrição, ou podem ser genes cuja regulação por ER- $\alpha$ ainda não foi descrita, portanto positivos verdadeiros. Outro resultado importante é a distribuição de energia de ligação para o receptor de $C$. elegans, NHR-28 isoforma a, a qual foi bastante semelhante àquelas encontradas para NRs humanos. Este resultado sugere que o TFBSAnalyzer pode realmente ser aplicado a TFs de outros seres vivos. 
Apêndice A

Anexos 
Tabela A.1: Genes filtrados pelo enriquecimento de sítios na região promotora e reconhecidos pelo MetaCore.

UniProt

A2BP1, AF-9, AKAP2, Alpha-catenin, Ankyrin-B, BAZ2B, BPAG1, BTBD11, CALN1, CAPON, CASP, CED-6, CMYA3, CNTLN, CNTN5, COL4A6, Cadherin 23, Calcipressin 2, Calsyntenin-2, Carom, Catenin alpha-3, Chapsyn-110, Collagen IV, Contactin 4, Copine-4, DAB1, DISC1, DLGAP1 (GKAP), Delta-sarcoglycan, Dystrobrevin alpha, Dystrophin, ELMO1, ETR3, FAM5C, FBXL13, FRMD5, INADL, KIF26B, KLHL29, Liprin-alpha2, MACF1, MACROD2, MAD1 (mitotic checkpoint), MPP7, Mob2 (HCCA2), Myomegalin, NAV2, NCAM1, NELL2, NOL4, NR2, NR2A, Nebulin NEB, Nesprin 1, Neurocalcin delta, Neuroligin 4, Neurotrimin, ODZ3, PALM2AKAP2, PHACTR1, PP2A regulatory, PP2A regulatory, RAD51B, RBMS3, SAP97 (DLG1), SPOCK, SPOCK3, Sarcoglycan complex, TIP(T cell immunomodulatory protein), Tmtc1, VEPH1, ZNF288, ZRAB3, eIF4G1/3, eIF4G3, mGluR5 ACOXL, COP1, CSMD3, Carbonic anhydrase X, Dhrsx, GALNT13, GASC1, GDPmannose 4,6 dehydratase, Gtdc1, HDAC8, HS6ST2, Histone deacetylase class I, LARGE, PDE11A, PDSS2, SMYD3

ADAM-TS6, ADAMTSL3

ARHGAP24, RABGAP1L, RGS6, RGS7, RalGEF2, TBC1D5, VAV-3

ATBF1, CUX1, CUX1 (p110), EBF, ERR3, FOXP1, FOXP1/2/4 proteins, ITF2, KLF12, LAF4, PAX5, SOX5, TCF12, ZNF423

ATP8B4, GIRK, K(+) channel, subfamily J, Kir3.2, NCX1, SLC14A2, TIM23-PAM complex, TRPM3

C10orf68, C14orf37, C14orf61, CAMTA1, CCDC46, CSMD2, Choline transporterlike protein 5, DIS3L2, DNAH6, Dynein ( axonemal, heavy chains), FAM101B, FAM135B, FGF13, KIAA0146, LOC51057, MIPOL1, Mdga2, Mirror-image polydactyly gene 1 protein, NBPF20, NIBP, NPIPL1, Neurexin 1-beta, Neuroblastoma breakpoint family member 20, PDE, PDE1, Protein C10orf68, Protein C9orf39, SLC44A5, Sfmbt2, TMCC1, Tim23, Transmembrane and coiled-coil domains protein 1, Uncharacterized protein C14orf37 precursor, Uncharacterized protein KIAA0146, WDR72, chromosome 20 open reading frame 133

CACNA1E, Ca(II) channels, KCNQ3

CAMK1D, JNK(MAPK8-10), JNK3(MAPK10), MGC16169, PKC, PKC-alpha, SRPK2, cPKC (conventional)

ETV6/NTRK3 fusion protein, Ephrin-A receptor 5, PDGF receptor, PDGF-R-alpha, ROR1, TrkC

Ephrin-A receptors, Neurexin 1-alpha, Neurexin alpha, Neurexin beta, PHOGRIN, Ryanodine receptor 2, Semaphorin 3E, TCR alpha locus, TCR alpha subunit, TCR alpha/beta

GABA-A receptor, GABA-A receptor alpha-1/beta-2/delta, GABA-A receptor alpha1/beta-2/gamma-1, GABA-A receptor alpha-1/beta-2/gamma-2, GABA-A receptor alpha-3/beta-1/gamma-3, GABA-A receptor alpha-3/beta-2/gamma-2, GABA-A receptor alpha-4/beta-2/delta, GABA-A receptor alpha-5/beta-2/gamma-2, GABAA receptor alpha-5/beta-3/gamma-3, GABA-A receptor alpha-6/beta-2/delta, GABA-A receptor alpha-6/beta-2/gamma-2, GABA-A receptor beta-2 subunit, GABA-A receptor gamma-3 subunit, GRIK4, Galpha(i)-specific metabotropic glutamate, Ionotropic glutamate receptor, Kainate receptor, NMDA receptor

\begin{tabular}{l|c}
\hline IGHE, IgE, Neuroligin & Receptor ligand \\
\hline IMMP2L, PCSK5 & Generic protease \\
\hline OATP-D, THADA & Transporter \\
\hline OBCAM & GPCR \\
\hline PALM2 & Generic kinase \\
\hline PPP2R2B & Protein phosphatase
\end{tabular}

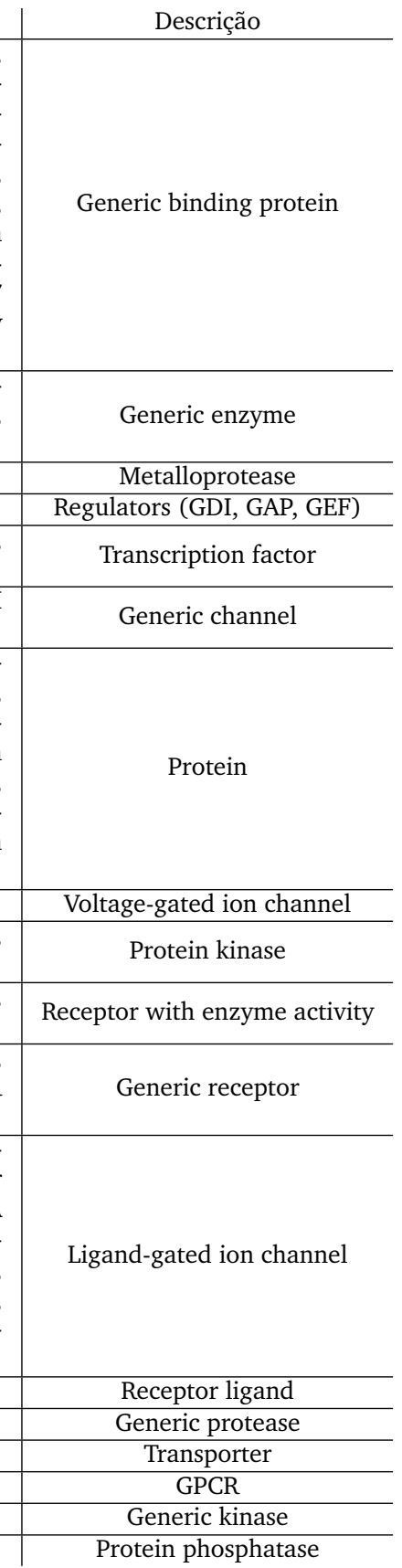




\section{Referências Bibliográficas}

Afonso, M. Q. L., de Lima, L. H., and Bleicher, L. (2013). Residue correlation networks in nuclear receptors reflect functional specialization and the formation of the nematode-specific p-box. BMC genomics, 14(Suppl 6):S1.

Alamanova, D., Stegmaier, P., and Kel, A. (2010). Creating pwms of transcription factors using 3d structure-based computation of protein-dna free binding energies. BMC Bioinformatics, 11:225-240.

Alexander, R. P., Fang, G., Rozowsky, J., Snyder, M., and Gernstein, M. B. (2010). Annotating non-coding regions of the genome. Nature Reviews: Genetics, 11:559571.

Altschul, S. F., Madden, T. L., Schaeffer, A. A., Zhang, J., Zhang, Z., Miller, W., and Lipman, D. J. (1997). Gapped blast and psi-blast: a new generation of protein database search programs. Nucleic Acid Research.

Arnone, M. I. and Davidson, E. H. (1997). The hardwiring of development: organization and function of genomic regulatory systems. Development, 124(10):1851-1864.

Ayers, S., Switnicki, M. P., Angajala, A., Lammel, J., Arumanayagam, A. S., and Webb, P. (2014). Genome-wide binding patterns of thyroid hormone receptor beta. PLOS ONE, 9.

Bailey, T. L. and Elkan, C. (1994). Fitting a mixture model by expectation maximization to discover motifs in biopolymers. Proceedings of the Second International Conference on Intelligent Systems for Molecular Biology, pages 28-36.

Bain, D. L., Henegan, A. F., Connanghan-Jones, K. D., and Miura, M. T. (2007). Nuclear receptor structure: Implications for function. Annu. Rev. Physiol.

Barrière, A. (2011). Distinct functional constraints partition sequence conservation in a cis-regulatory element. PLoS Genet., 7.

Birnbaumer, M., Schrader, W. T., and OMalley, B. W. (1983). Assessment of structural similarities in chick oviduct progesterone receptor subunits by partial proteolysis of photoaffinity labeled proteins. J. Biol. Chem., 258:7331-7337. 
Buck, M. J. and Lieb, J. D. (2004). Chip-chip: considerations for the design, analysis, and application of genome-wide chromatin immunoprecipitation experiments. Genomics, 83:349-360.

Buratowski, S. and Chodosh, L. A. (2001). Mobility shift dna-binding assay using gel electrophoresis. Current Protocols in Molecular Biology.

Canutescu, A. A., Shelenkov, A. A., and Dunbrack, R. L. J. (2003). A graph-theory algorithm for rapid protein side-chain prediction. Protein Sci.

Cañestro, C., Postlethwait, J. H., Gonzàlez-Duarte, R., and Albalat, R. (2006). Is retinoic acid genetic machinery a chordate innovation? Evolution and Development.

Chanbom, P. (1992). A decade of molecular biology of retinoic acid receptors. FASEB, 10:940-954.

Cotnoir-White, D., Laperrière, D., and Mader, S. (2011). Evolution of the repertoire of nuclear receptor binding sites in genomes. Molecular and Cellular Endocrinology, 334:76-82.

Elangovan, S., Ramachandran, S., Venkatesan, N., Ananth, S., Gnana-Prakasam, J. P., Martin, P. M., Browning, D. D., Schoenlein, P. V., Prasad, P. D., Ganapathy, V., et al. (2011). Sirt1 is essential for oncogenic signaling by estrogen/estrogen receptor $\alpha$ in breast cancer. Cancer research, 71(21):6654-6664.

ENCODE (2012). An integrated encyclopedia of dna elements in the human genome. Nature.

Essman, U., Perera, L., Berkowitz, M. L., Darden, T., Lee, H., and Pedersen, L. G. (1995). A smooth particle mesh ewald method. J.Chem.Phys.B.

Fogel, G. B., Weeks, D. G., Varga, G., Dow, E. R., Craven, A. M., Harlow, H. B., Su, E. W., Onyia, J. E., and Su, C. (2005). A statistical analysis of the transfac database. BioSystems.

Georges, A. B., Benayoun, B. A., Caburet, S., and Veitia, R. A. (2010). Generic binding sites, generic dna-binding domains: where does specific promoter recognition come from? FASEB Journal, 24:346-356.

Giulianelli, S., Vaqué, J. P., Soldati, R., Wargon, V., Vanzulli, S. I.and Martins, R., Zeitlin, E., Molinolo, A. A., Helguero, L. A., Lamb, C. A., Gutkind, J. S., and Lanari, C. (2012). Estrogen receptor alpha mediates progestin-induced mammary tumor growth by interacting with progesterone receptors at the cyclin $\mathrm{d} 1 /$ myc promoters. Cancer Research AACR.

Hobert, O. (2008). Gene regulation by transcription factors and micrornas. Science Signaling, 319:1785-1786. 
Hooft, R. W. W., Sander, C., and Vriend, G. (1996a). The pdbfinder database: A summary of pdb, dssp and hssp information with added value. CABIOS/Bioinformatics.

Hooft, R. W. W., Vriend, G., Sander, C., and Abola, E. E. (1996b). Errors in protein structures. Nature.

Jen-Jacobson, L., Engler, L. E., and Jacobson, L. A. (2000). Structural and thermodynamic strategies for site-specific dna binding proteins. Structure, 8(10):1015-1023.

Kel, A. E., Goßling, E., Reuter, I., Cheremushkin, E., Kel-Margoulis, O. V., and Wingender, E. (2003). Matchtm: a tool for searching transcription factor binding sites in dna sequences. Nucleic Acids Research, 31:3576-3579.

Kent, W. J., Sugnet, C. W., Furey, T. S., Roskin, K. M., Pringle, T. H., Zahler, A. M., and Haussler, D. (2002). The human genome browser at ucsc. Genome Res., 12:9961006.

Klinge, C. M. (2001). Estrogen receptor interaction with estrogen response elements. Nucleic Acid Research.

Klug, A. (2010). The discovery of zinc fingers and their applications in gene regulation and genome manipulation. Annual Reviews Biochemistry, 79:213-231.

Koudritsky, M. and Domany, E. (2008). Positional distribution of human transcription factor binding sites. Nucleic Acids Res., 36:6795-805.

Krieger, E., Darden, T., Nabuurs, S., Finkelstein, A., and Vriend, G. (2004). Making optimal use of empirical energy functions: force field parameterization in crystal space,. Proteins.

Krieger, E., Nielsen, J. E., Spronk, C. A., and Vriend, G. (2006). Fast empirical pka prediction by ewald summation. J.Mol.Graph.Model.

Kulakovskiy, I. V., Medvedeva, Y. A., Schaefer, U., Kasianov, A. S., Vorontsov, I. E., Bajic, V. B., and Makeev, V. J. (2013). Hocomoco: a comprehensive collection of human transcription factor binding sites models. Nucleic Acids Research, 41:195-202.

Larkin, M. A., Blackshields, G., Brown, N. P., Chenna, R., McGettigan, P. A., McWilliam, H., Valentin, F., Wallace, I. M., Wilm, A., Lopez, R., Thompson, J. D., Gibson, T. J., and Higgins, D. G. (2007). Clustalw and clustalx version 2. Bioinformatics, 23:29472948.

Lee, T. I. and Young, R. A. (2000). Transcription of eukaryotic protein-coding genes. Annual Reviews Genetics, 34:77-137.

Levine, M. and Tjian, R. (2003). Transcription regulation and animal diversity. Nature, 424(6945):147-151. 
Li, B., Carey, M., and Workman, J. L. (2007). The role of chromatin during transcription. Cell, 128(4):707-719.

Liu, X., Brutlag, D. L., and Liu, J. S. (2001). Bioprospector: Discovering conserved dna motifs in upstream regulatory regions of co-expressed genes. Pacific Symposium on Biocomputing, 6:127-138.

Luscombe, N. M., Laskowski, R. A., and Thornton, J. M. (2001). Amino acid-base interactions: a three-dimensional analysis of protein-dna interactions at an atomic level. Nucleic acids research, 29(13):2860-2874.

Mader, S., Chanbom, P., and White, J. H. (1993). Defining a minimal estrogen receptor dna binding domain. Nucleic Acid Researchs, 21:1125-1132.

Mangelsdorf, D. J., Thummel, C., Beato, M., Herrlich, P. amd Schutz, G., Umesono, K., Blumberg, B., Kastner, P., Mark, M., Chanbom, P., and Evans, R. M. (1995). The nuclear receptor superfamily: The second decade. Cell, 83:835-839.

Matys, V., Kel-Margoulis, O. V., Fricke, E., Liebich, I., Land, S., Barre-Dirrie, A., Reuter, I., Chekmenev, D. amd Krull, M., Hornischer, K., Voss, N., Stegmaier, P., LewickiPotapov, B., Saxel, H., Kel, A. E., and Wingender, E. (2006). Transfac and its module transcompel: transcriptional gene regulation in eukaryotes. Nucleic Acids Research, 24:108-110.

Moazed, D. (2001). Common themes in mechanisms of gene silencing. Molecular cell, 8(3):489-498.

Nelson, D. L. and Cox, M. M. (2005). Lehninger Principles of Biochemistry, chapter 28, page 1090. Freeman.

Nguyen, D., Bail, M., Pesant, G., Dupont, V. N., Rouault, E., Deschênes, J., Rocha, W., Melançon, G., Steinberg, S. V., and Mader, S. (2007). Rational design of an estrogen receptor mutant with altered dna-binding specificity. Nucleic Acids Research, $35: 3465-3477$.

Pabo, C. O. and Sauer, R. T. (1992). Transcription factors: Structural families and principles of dna recognition. Annual Reviews Biochemistry, 61:1053-1095.

Park, P. J. (2009). Chip-seq: advantages and challenges of a maturing technology. Nature Reviews: Genetics, 10:669-680.

Renaud, J. P. and Moras, D. (2000). Structural studies on nuclear receptors. Cellular and Molecular Life Sciences, 57:1748-1769.

Ruiz, M. M. V., Bugge, T. H., Hirschmann, P., and Stunnenberg, H. G. (1991). Functional characterization of a natural retinoid acid responsice element. The EMBO Journal. 
Sandelin, A., Alkema, W., Engström, P., Wasserman, W. W., and Lenhard, B. (2004). Jaspar: an open-access database for eukaryotic transcription factor binding profiles. Nucleic Acids Research, 32:91-94.

Shlyueva, D., Stampfel, G., and Stark, A. (2014). Transcriptional enhancers: from properties to genome-wide predictions. Nature Reviews Genetics, 15(4):272-286.

Siegel, R., Naishadham, D., and Jemal, A. (2013). Cancer statistics, 2013. CA: A Cancer Journal for Clinicians.

Simões-costa, M. S., Azambuja, A. P., and Xavier-Neto, J. (2008). The search for nonchordate retinoic acid signaling: lessons from chordates. Journal of Experimental Zoology Part B: Molecular and Developmental Evolution.

Spitz, F. and Furlong, E. E. (2012). Transcription factors: from enhancer binding to developmental control. Nature Reviews Genetics, 13(9):613-626.

Stoltenburg, R., Reinemann, C., and Strehlitz, B. (2007). Selex - a (r)evolutionary method to generate high-affinity nucleic acid ligands). Biomolecular Engineering, 24:381-400.

Tuerk, C. and Gold, L. (1990). Systematic evolution of ligands by exponential enrichment: Rna ligands to bacteriophage t4 dna polymerase. Science, 249:505-510.

Wahli, W. and Martinez, E. (1991). Superfamily of steroid nuclear receptors: positive and negative regulators of gene expression. FASEB Journal, 5:2243-2249.

Wang, J., Cieplak, P., and Kollman, P. A. (2000). How well does a restrained electrostatic potential (resp) model perform in calculating conformational energies of organic and biological molecules? Journal of Computational Chemistry.

Weingarten-Gabbay, S. and Segal, E. (2014). The grammar of transcriptional regulation. Human genetics, 133(6):701-711.

Yu, M., Yang, X.-Y., Schmidt, T., Chinenov, Y., Wang, R., and Martin, M. E. (1997). Ga-binding protein-dependent transcription initiator elements effect of helical spacing between polyomavirus enhancer a factor 3 (pea3)/ets-binding sites on initiator activity. Journal of Biological Chemistry, 272(46):29060-29067.

Zhao, C., Dahlman-Wrigth, K., and Gustafsson, J. (2008). Estrogen receptor beta: an overview and update. NURSA.

Ziouzenkova, O., Orasanu, G.and Sharlach, M., Akiyama, T. E., Berger, J. P., Viereck, J., Hamilton, J. A., Tang, G., Dolnikowski, G. G., Vogel, S., Duester, G., and Plutzky, J. (2007). Retinaldehyde represses adipogenesis and diet-induced obesity. Nature Medicine. 